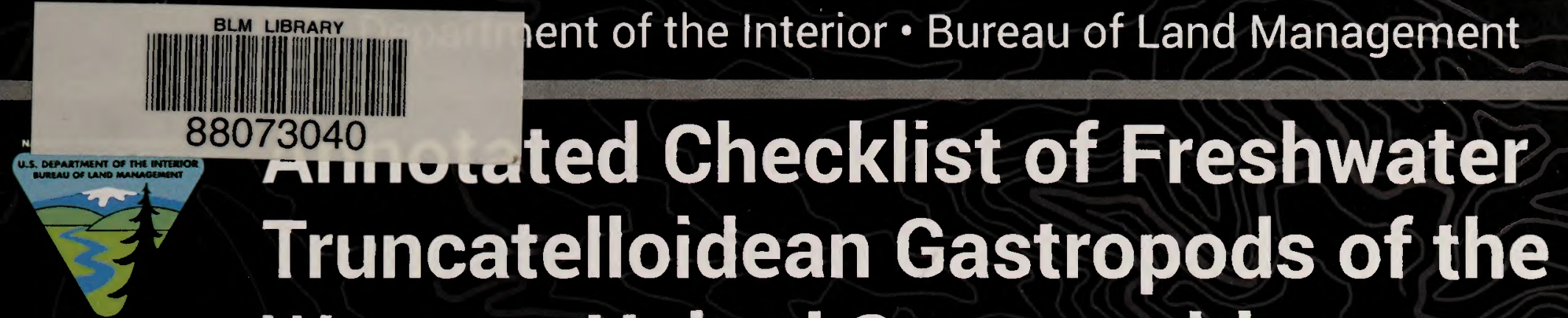 Western United States, with an Illustrated Key to the Genera
}

Technical Note 449 
Cover photo: Live specimen of Pyrgulopsis robusta (Snake River, Idaho). Photo by Robert Hershler.

Production services provided by the Bureau of Land Management National Operations Center's Information and Publishing Services Section in Denver, Colorado.

Suggested Citation:

Hershler, R. and H.-P. Liu. 2017. Annotated checklist of freshwater truncatelloidean gastropods of the western United States, with an illustrated key to the genera. Technical Note 449. U.S. Department of the Interior, Bureau of Land Management, National Operations Center, Denver, CO. 


\section{Annotated Checklist of Freshwater Truncatelloidean Gastropods of the Western United States, with an Illustrated Key to the Genera}

Technical Note 449

\section{Authors:}

Robert Hershler

Department of Invertebrate Zoology

Smithsonian Institution

Washington, DC 20013-7012

\section{Hsiu-Ping Liu}

Department of Biology

Metropolitan State University of Denver

Denver, CO 80217

U.S. Department of the Interior

Bureau of Land Management

June 2017 


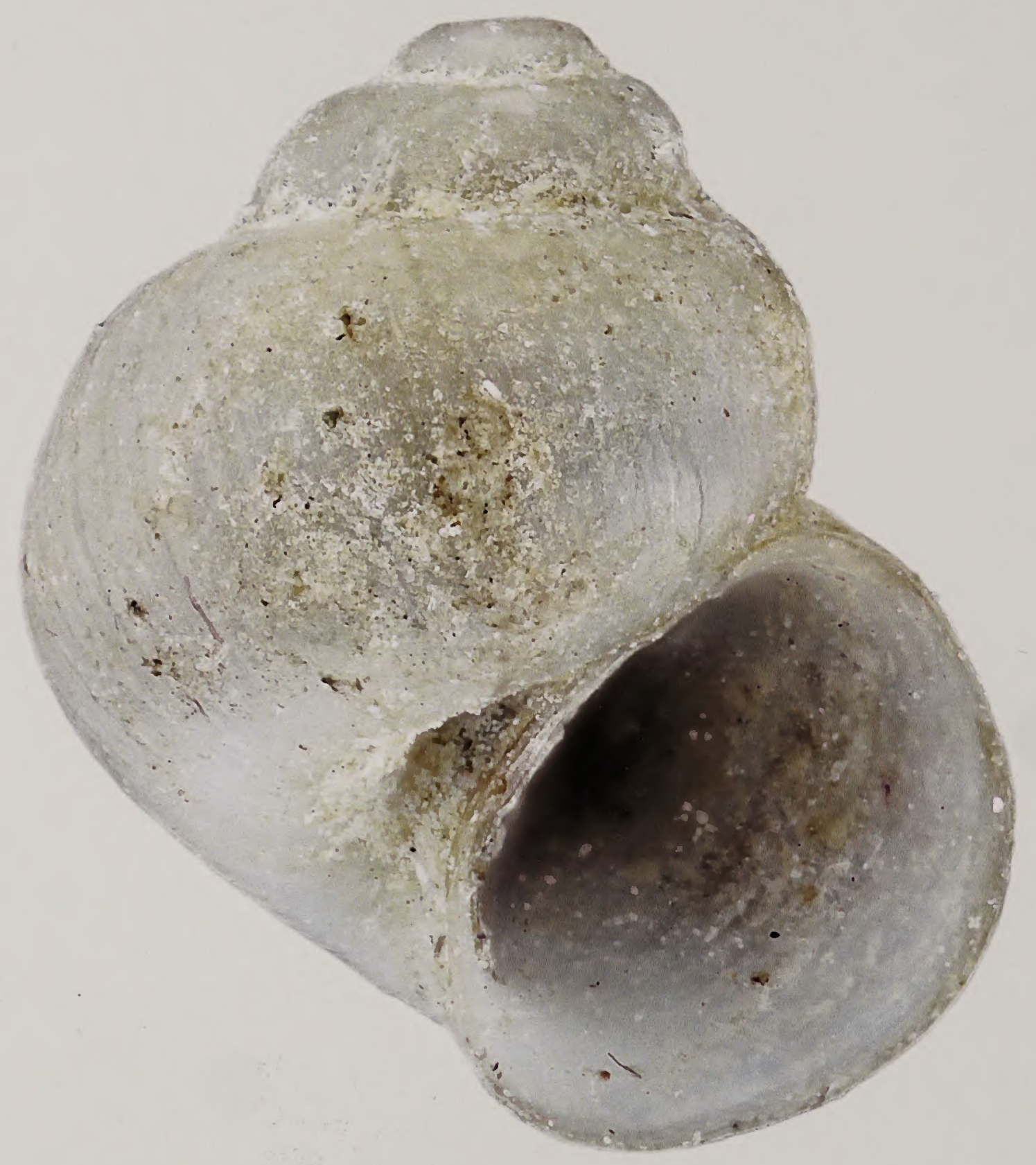




\section{Acknowledgments}

Freya Goetz photographed preserved snails and prepared the figures. Dominique Ware helped compile the COI sequence data. Jeanette Howard provided useful comments on an early draft of this paper. This project was supported (in part) by a contract (\# 06132013-1651) from The Nature Conservancy. Our manuscript was significantly improved by the input from Barry Roth and two anonymous reviewers.

We also thank Melissa Dickard for her assistance in facilitating those reviews and Linda Hill for carefully editing the manuscript. 


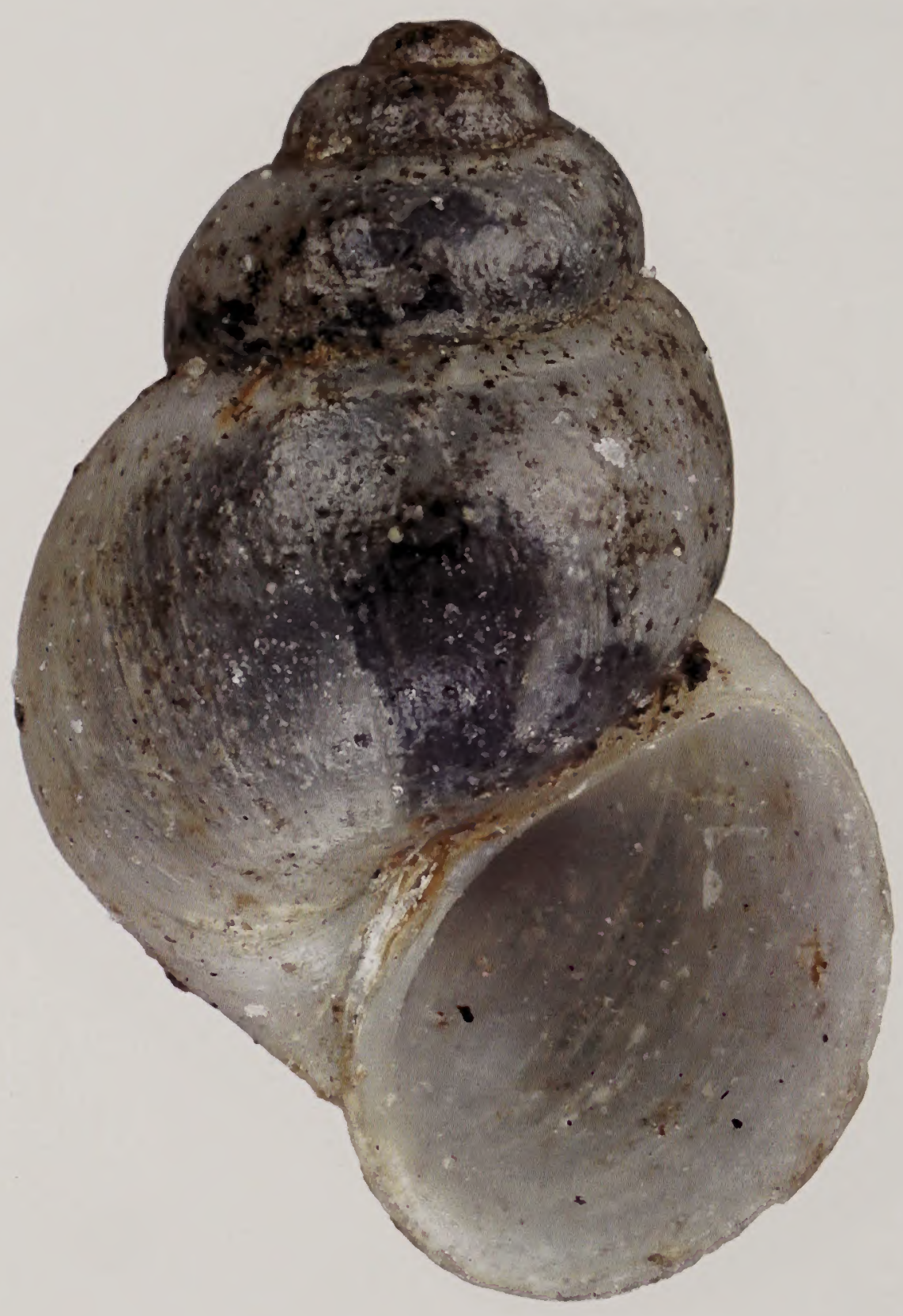




\section{Contents}

Abstract ........................ vii

Introduction $\ldots \ldots \ldots \ldots \ldots \ldots \ldots \ldots \ldots \ldots \ldots \ldots \ldots \ldots \ldots \ldots \ldots$

Methods. . . . . . . . . . . . . . . . . . . . . . . .

Key to the Freshwater Truncatelloidean Genera of the Western United States . . . .9

Species Checklist . . . . . . . . . . . . . . . . . . 15

Literature Cited. . . . . . . . . . . . . . . . . . . 73

Appendix . . . . . . . . . . . . . . . . . . . . . 85 


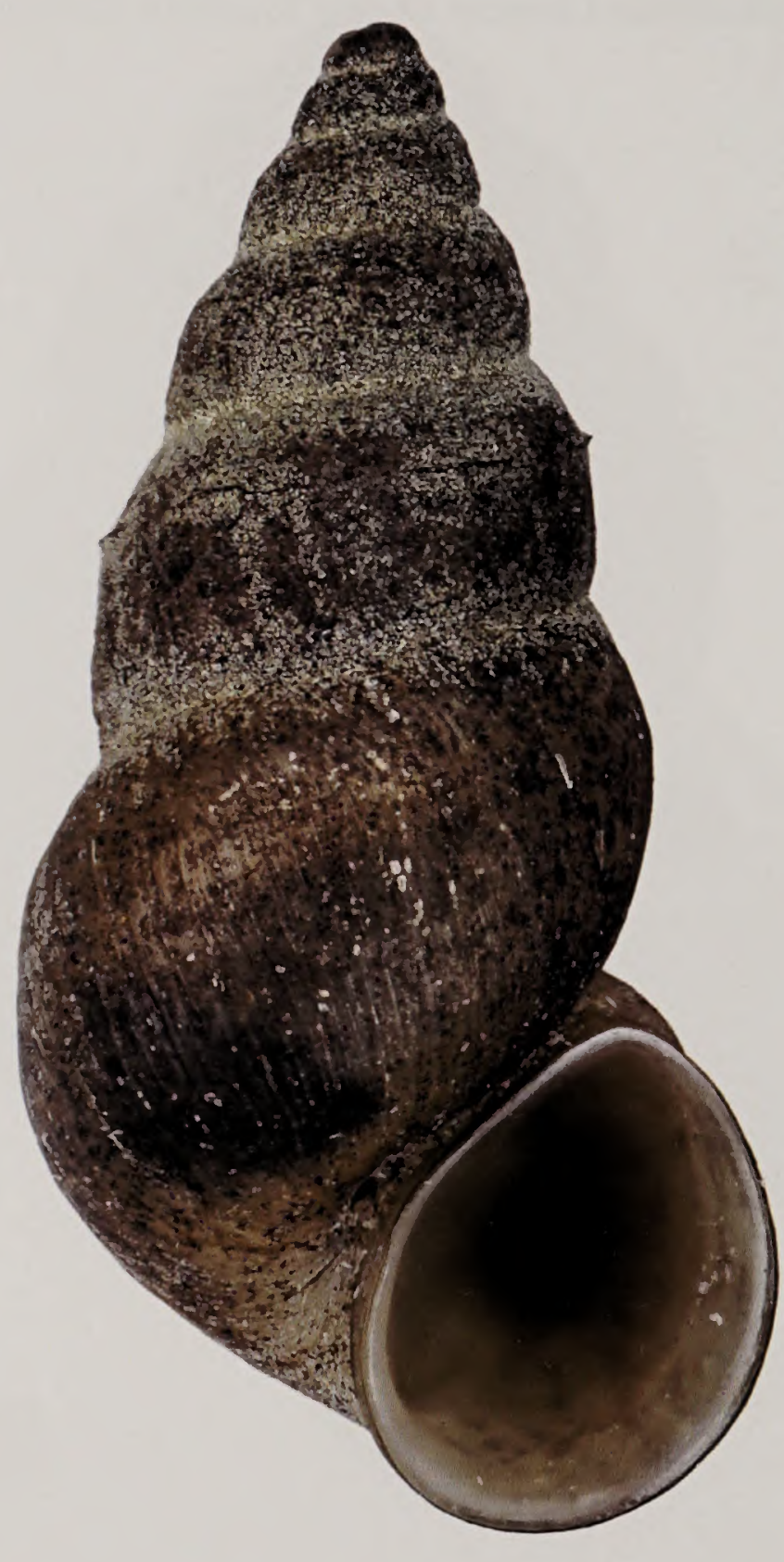




\section{Abstract}

This technical note provides an illustrated key to the 13 genera and a checklist for the 178 currently recognized species of freshwater, inland saline, and estuarine truncatelloidean gastropods (primarily belonging to the families Amnicolidae, Cochliopidae, Hydrobiidae, Lithoglyphidae, and Tateidae) in the western United States. It also outlines methods of specimen preparation and dissection to facilitate use of the generic key. The checklist includes bibliographic information for each species (and their synonyms), type localities, type material, and geographic distributions. The appendix includes a comprehensive synopsis of the available DNA barcoding sequences (the COI gene, cytochrome $c$ oxidase subunit I) for members of this fauna in the anticipation that these data will be increasingly used for both taxonomic and conservation genetic applications. This technical note serves as an entry portal for resource managers, taxonomists, and other individuals interested in this species-rich and highly imperiled fauna. 


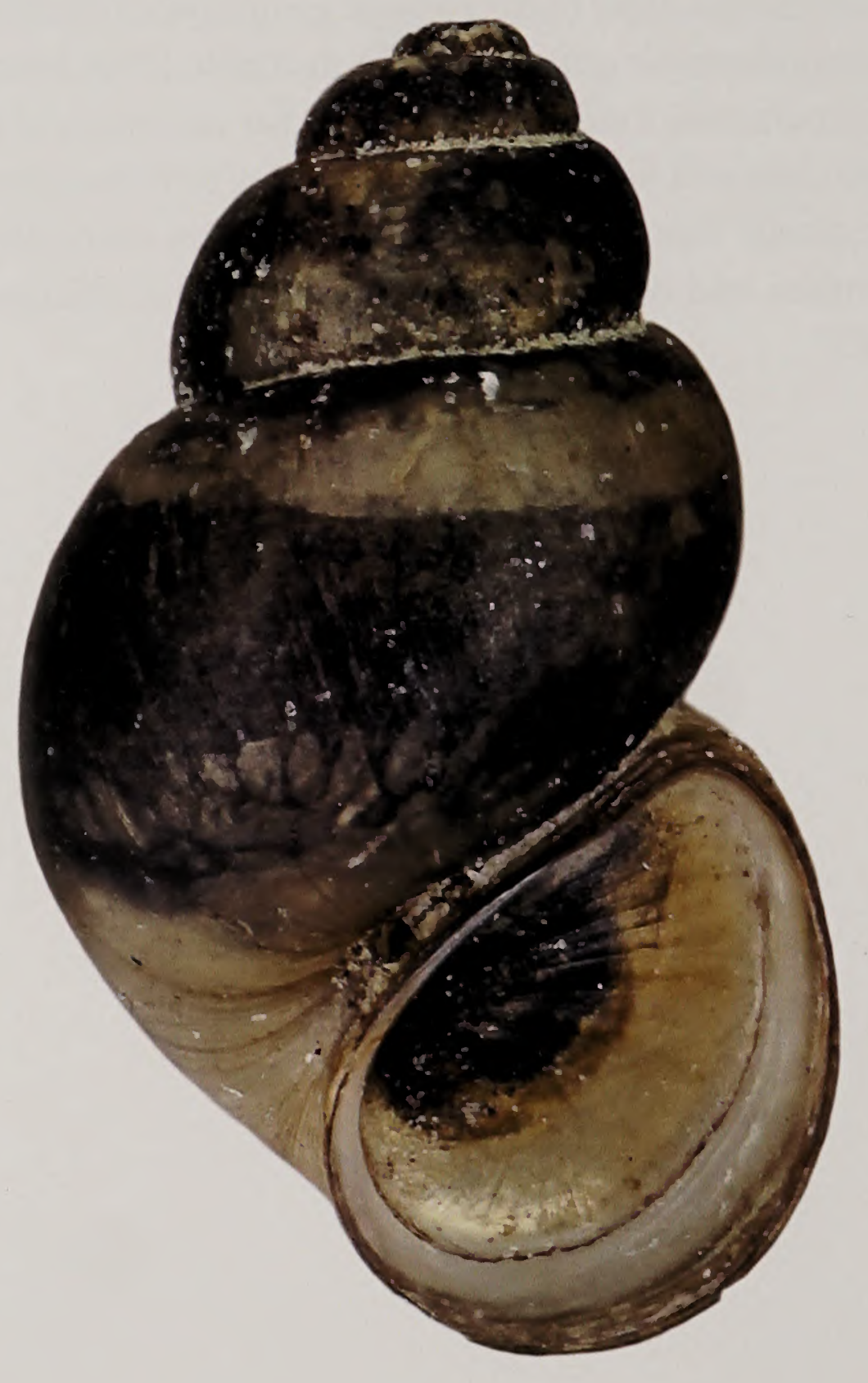




\section{Introduction}

The western United States contains a large, highly endemic fauna of gastropods belonging to the superfamily Truncatelloidea (totaling 178 species, Table 1), which has recently become a major focus of conservation actions because of the various threats to its typically groundwater-dependent habitats (e.g., Pyrgulopsis, Hershler et al. 2014a). These snails are a challenging group to study because of their diminutive size (the shells of most species are $<10 \mathrm{~mm}$ long) and rather featureless and monotonous shells; identification of these animals to useful taxonomic levels usually requires the examination of soft parts, particularly the genitalia. In spite of the increasing interest from the conservation community, there are no recently published overviews of this fauna, which has mushroomed in size (from 33 to 178 species) and otherwise been extensively revised taxonomically (e.g., Hershler 1994; Hershler and Frest 1996; Hershler 2001) since the last such compilations were published over 30 years ago (Taylor 1975; Burch and Tottenham 1980; Burch 1982). The purpose of this technical note is to provide a synopsis of the freshwater truncatelloidean snails in the western United States that can serve as an entry point for members of the conservation community and other biologists interested in studying these long neglected and still poorly known animals. The generic key and accompanying illustrations may also assist land managers and conservation biologists in their efforts to track the spread of the New Zealand mudsnail (Potamopyrgus antipodarum), a highly invasive pest that is easily confused with other truncatelloidean snails (ANS Task Force 2005). This technical note includes a simple, illustrated key to differentiate the freshwater truncatelloidean genera of the western United States, images of representative shells of each genus, and an annotated checklist (and bibliography) for all of the currently recognized regional species ( 175 native, 3 introduced). We also provide a detailed compilation of published mitochondrial DNA sequences of the "barcoding" gene (COI, cytochrome $c$ oxidase subunit I) for the freshwater truncatelloideans in the western United States; these data have proved to be an invaluable tool for taxonomic studies of these animals and are also beginning to be used to identify conservation management units (e.g., Hurt 2004). 

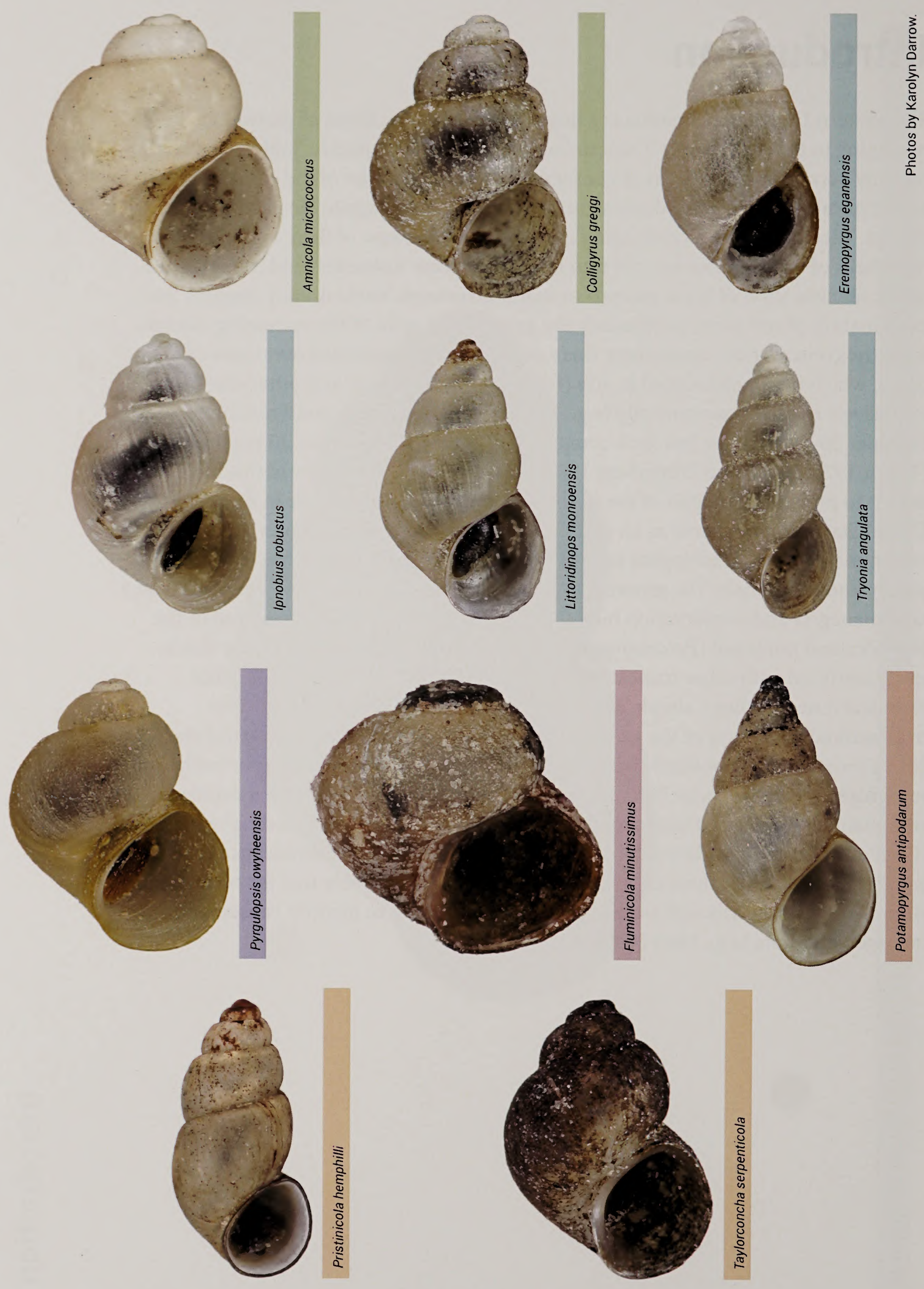


\section{Methods}

The geographic scope of this technical note is the conterminous United States west of the Continental Divide, which includes all of Arizona, California, Idaho, Nevada, Oregon, Utah, Washington, and portions of Colorado, Montana, New Mexico, and Wyoming (Figure 1). We treat all of the currently recognized freshwater, inland saline, and estuarine taxa of the caenogastropod superfamily Truncatelloidea that have been recorded from this region, totaling 178 species (175 native) in 12 genera (Table 1). We also include one (freshwater) snail of uncertain species status belonging to a 13th western genus. Three species are distributed in estuarine waters, while 173 species live in inland aquatic habitats; two species (Potamopyrgus antipodarum, Tryonia porrecta) are distributed in both of these habitats. The technical note does not include the few semiterrestrial truncatelloideans (belonging to the families Assimineidae and Pomatiopsidae) that are distributed in the western United States.

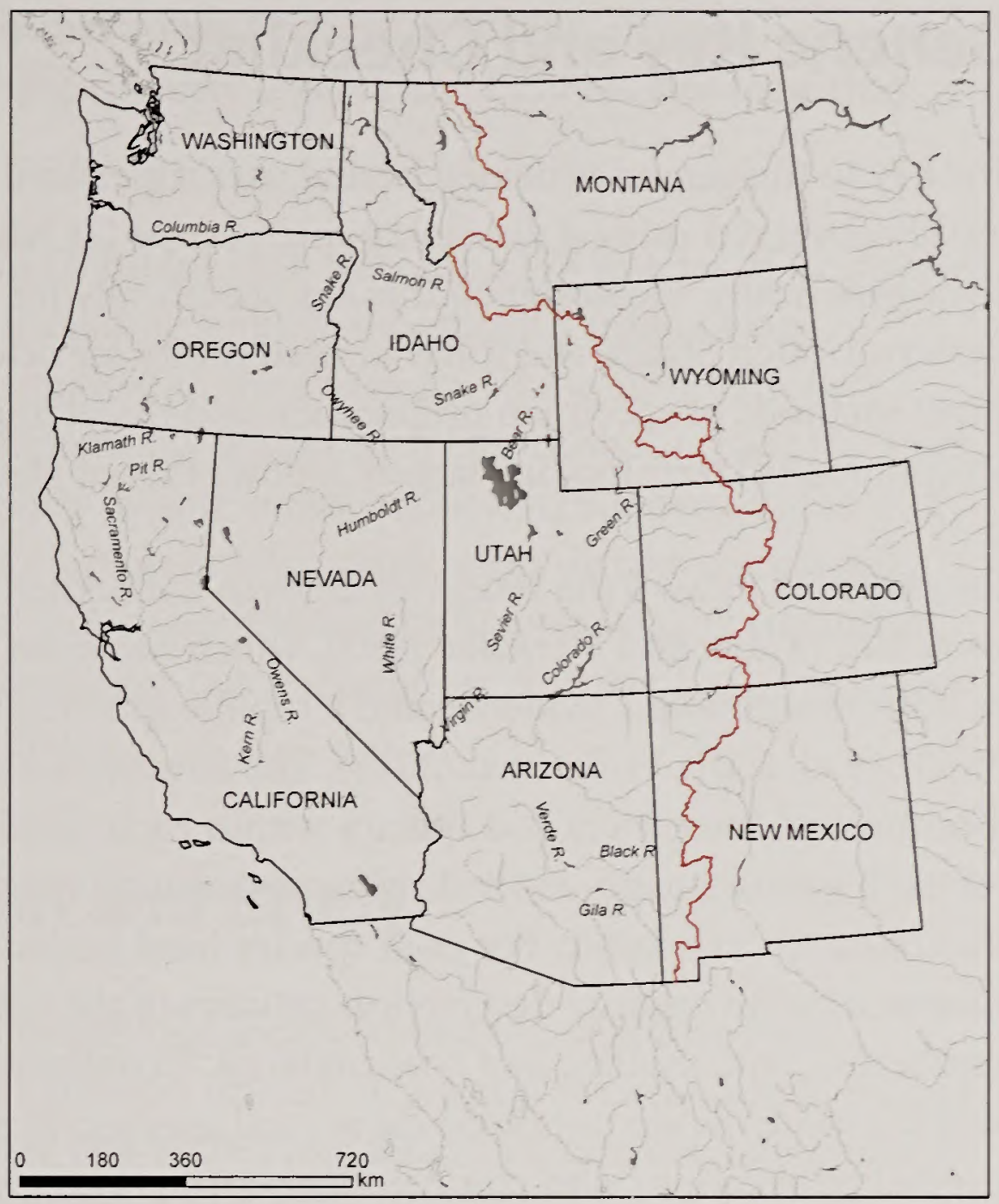

Figure 1. The western United States study area, consisting of those states or portions of states that are west of the Continental Divide (indicated by the red line).

Table 1. Classification of the freshwater truncatelloidean gastropods of the western United States.

\begin{tabular}{llc}
\hline Family & Genus & No. of species \\
\hline AMNICOLIDAE & Amnicola & 1 \\
\cline { 2 - 3 } & Colligyrus & 3 \\
& Lyogyrus & $1^{\star}$ \\
\hline \multirow{4}{*}{ COCHLIOPIDAE } & Eremopyrgus & 1 \\
\cline { 2 - 3 } & Ipnobius & 1 \\
\hline & Littoridinops & $1 \star \star$ \\
\cline { 2 - 3 } & Spurwinkia & $1 \star \star$ \\
\hline HYDROBIIDAE & Tryonia & 14 \\
\hline \multirow{2}{*}{ LITHOGLYPHIDAE } & Pyrgulopsis & 126 \\
\hline TATEIDAE & Fluminicola & 25 \\
\hline UNCERTAIN & Potamopyrgus & $1 \star \star$ \\
\hline & Pristinicola & 1 \\
\hline & Taylorconcha & 2 \\
\hline
\end{tabular}

* Uncertain species status.

$\star \star$ Introduced to the western United States. 


\section{Generic Key and Checklist}

The key to the genera provided herein uses superficial character states that can be readily observed using a dissecting microscope (at 50x) and is not structured phylogenetically. We designed this key specifically for the distinctive fauna of the western United States, and it has limited utility for other geographic areas. We also detail methods of specimen preparation and dissection to facilitate the use of this key. Morphological terminology largely follows that of Hershler and Ponder (1998).

The checklist follows the recent changes in the higher taxonomy of the Hydrobiidae sensu lato (Kabat and Hershler 1993), which has been split into multiple families based on both morphologic evidence and a rapidly growing body of molecular evidence (Wilke et al. 2001; Wilke et al. 2013). The families are arranged alphabetically in the checklist and the genera and species within each family are also listed in this manner. For each genus, images of shells of representative species are provided; types are illustrated when feasible. For each species (and junior synonyms thereof), the reference to the original description consists of the author(s), date, page(s) and figure number(s), type locality, and type material. Extralimital (outside the western United States) synonyms are not listed for several species. Type localities are listed as in the original publication, with comments or corrections given in brackets. The list of secondary types may not be complete for some species.

The institutions and museums where the cited types (and other referenced material) are housed are identified by the following acronyms: ALBRCIDA, Orma J. Smith Museum of Natural History, The College of Idaho, Caldwell, Idaho (formerly Albertson College of Idaho); ANSP, Academy of Natural Sciences of Drexel University, Philadelphia, Pennsylvania; CAS, California Academy of Sciences, San Francisco, California; LACM, Los Angeles County Museum, Los Angeles, California (now the Natural History Museum of Los Angeles County); MCZ, Museum of Comparative Zoology, Harvard University, Cambridge, Massachusetts; NHMUK, Natural History Museum, London, England; NMW, Naturhistorisches Museum Wien, Vienna, Austria; SBMNH, Santa Barbara Museum of Natural History, Santa Barbara, California; UF, Florida Museum of Natural History, University of Florida, Gainesville, Florida; UMMZ, University of Michigan, Museum of Zoology, Ann Arbor, Michigan; USNM, National Museum of Natural History, Smithsonian Institution, Washington, DC; UTEP, University of Texas at El Paso, El Paso, Texas (now the Centennial Museum and Chihuahuan Desert Gardens).

The common name for each species is listed following Turgeon et al. (1998) and Johnson et al. (2013); new (common) names are introduced for several recently described species. The geographic distribution of each species is given based on the most current published information, with references provided when this source postdates the original descriptions. The taxonomy section lists papers that provide 
illustrations that are useful for identification purposes (excluding original descriptions). The remarks section is primarily used to highlight species requiring taxonomic revision.

The COI sequences are available (in GenBank) for 160 of the 178 species of freshwater truncatelloideans in the checklist, including some taxonomically undescribed populations; these sequences are compiled in the appendix. These summaries are arranged by genus and species alphabetically within each family and include (for each sequence) the species name, published sample codes, accession numbers, number of specimens $(\mathrm{N})$, sequence variation (\% pairwise distance), most distant conspecific sequences (\%), closest interspecific sequences (\%), and collection locality (including county and state). The sequence divergence comparisons are restricted to populations and species in the western United States.

\section{Specimen Preparation and Study}

Freshwater truncatelloidean snails usually are locally abundant, enabling ready collection of sizeable samples (i.e., $>100$ specimens). A portion of each sample should be directly preserved in concentrated (90-100\%) nondenatured ethanol; half of these specimens can be subsequently (air-) dried and designated as shell vouchers while the rest can be retained (in ethanol) for possible DNA analysis. The remaining portion of the live sample should be anesthetized (relaxed) with menthol crystals (prior to fixation and preservation) to facilitate examination of soft parts required for identification. (Menthol is an organic compound obtained from mint plants that is readily available in crystalline form from chemical supply houses.) Relaxed material is particularly useful for study of the penis, while pertinent details of the female genitalia usually can be obtained from contracted specimens that were directly preserved in ethanol. Snails should be relaxed in a large container (such as a 1-pint [473-ml] Mason jar) that is nearly filled with habitat water and kept cool and out of the sun. A small quantity (about half a teaspoon) of powdered menthol crystals (they can be crushed in one's hand) should be sprinkled over the water surface, after which the container should be capped and left undisturbed. The snails usually require about 13 hours for proper relaxation, although some species (e.g., Pyrgulopsis robusta) may require considerably more time. Once the specimens are anesthetized, at which time the head-foot is well extended and insensitive to touch, most of the water should be decanted and dilute formalin ( $10 \%$ of stock solution) should be slowly added. After 4-6 hours of fixation, the material should be rinsed and preserved in $70 \%$ ethanol.

Alcohol-preserved snails can be quickly separated from their shells by placing them in a small quantity of concentrated hydrochloric acid (which dissolves the calcareous shell). The appearance of the distal portion of the oviduct-whether it is glandular (Figure 2A) or thin-walled and containing brooded young (Figure 2B) - can be readily 
determined without dissection. The bursa copulatrix can be viewed by pinning the animal, cutting the mantle along the left side of the head-foot, and pulling this tissue over (as shown in Figure 2A) to expose the oviduct and associated structures (Figure 2C-D). The penis is attached to the "neck" of the snail behind the snout and usually extends beyond the mantle edge (Figure 3A-C); both the upper (dorsal) and lower (ventral) surfaces of the penis should be examined for glands, which are relatively large and quite obvious; the internal penial glands of amnicolids are clearly visible in appropriately prepared specimens (Figure 3D). We recommend that workers practice the methods of anesthetizing, preserving, and dissecting snails before applying them to essential specimens.

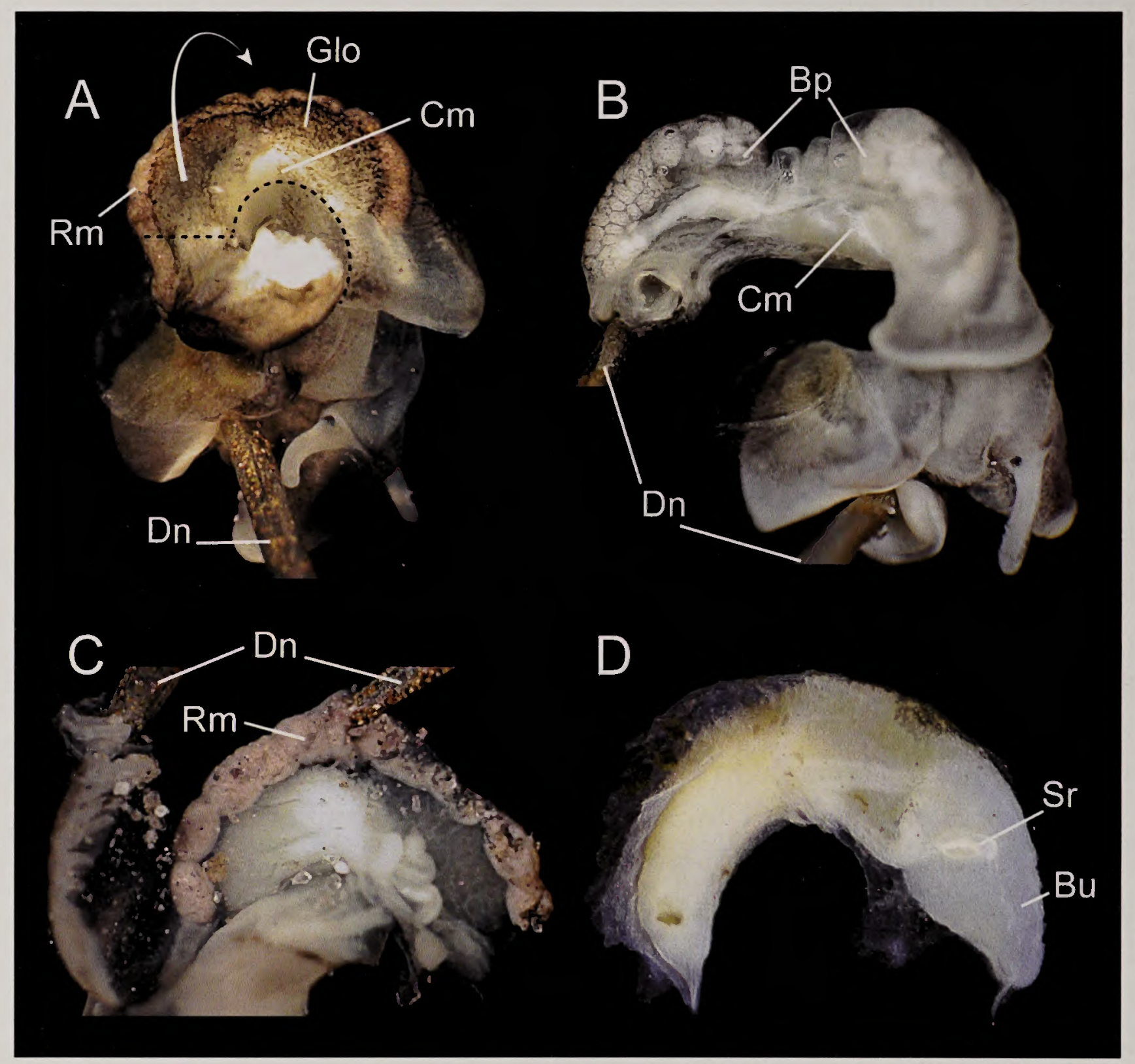

Figure 2. Photographs of female snails. A. Oviparous specimen having a thickened, glandular oviduct (Pyrgulopsis). Dashed black lines indicate the incisions made prior to pulling the tissue over (in the direction of the curved white arrow) to expose the left side of the oviduct and the associated structures (shown in C-D). B. Ovoviviparous specimen with thin-walled oviduct containing brooded young (Tryonia). C-D. Left side of glandular oviduct and associated structures (Pyrgulopsis). $\mathrm{Bp}$, brood pouch; Bu, bursa copulatrix; $\mathrm{Cm}$, columellar muscle; Dn, dissecting needle; Glo, glandular oviduct; $\mathrm{Rm}$, rectum; Sr, seminal receptacle. 


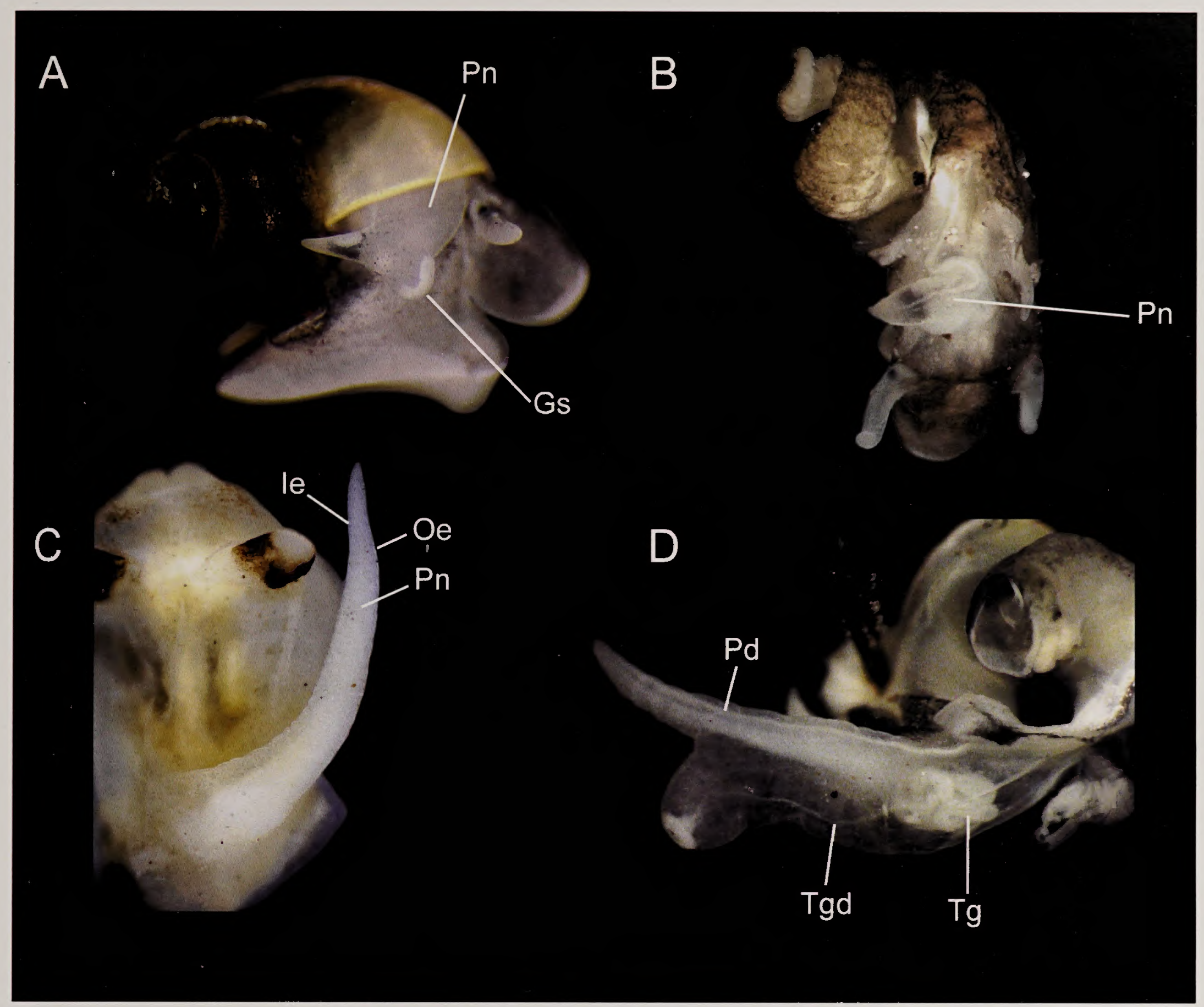

Figure 3. Photographs of male snails. A. Relaxed specimen with extended penis (Pyrgulopsis). B-C. Specimens with portion or all of pallial roof removed to show attachment of penis to "neck." (Pyrgulopsis, Taylorconcha, respectively). D. Penis with internal "tubular" gland (Amnicola). Gs, glandular strip, le, inner edge of penis; Oe, outer edge of penis; Pd, penial duct; Pn, penis; Tg, tubular gland; Tgd, tubular gland duct. 







\section{Key to the Freshwater \\ Truncatelloidean Genera of the \\ Western United States}

1. Female oviduct glands well developed (oviparous reproductive mode) (Figure 2A), shell globose to turriform 2

Female oviduct glands reduced, serving as brood pouch (ovoviviparous) (Figure 2B), shell conical to turriform 11

2. Penial glands absent (Figure 3B-C) 3

Penial glands present (Figure 3A, D) 7

3. Terminal papilla of (distal end of) penis large (Figure 4A);

estuarine

\section{Spurwinkia}

Terminal papilla of (distal end of) penis very small or absent

(Figure 4B-G); inland aquatic 4

Figure 4.

Drawings of penes

(dorsal aspect).

A. Spurwinkia salsa.

B. Fluminicola fuscus.

C. Fluminicola virens.

D. Taylorconcha

serpenticola.

E. Pyrgulopsis lockensis.

F. Pyrgulopsis millenaria.

G. Pristinicola hemphilli.

Distal edge to left.

$\mathrm{Pd}$, penial duct;

$\mathrm{Tp}$, terminal papilla.
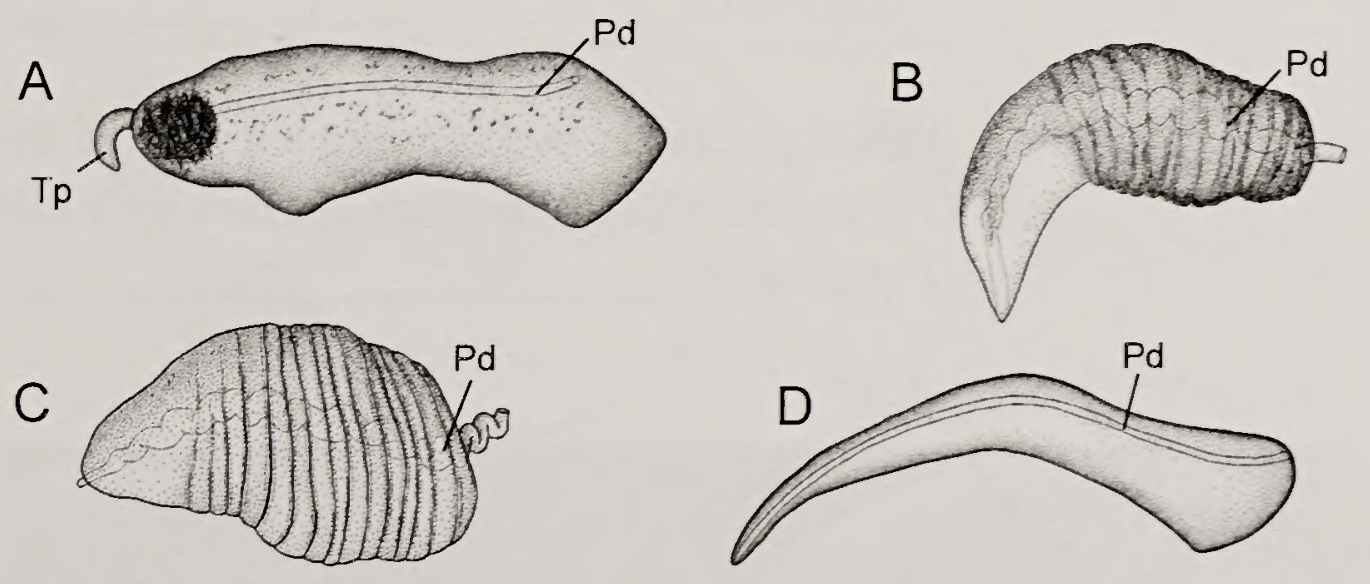

要 
4. Bursa copulatrix absent (Figure 5A)

Taylorconcha

A
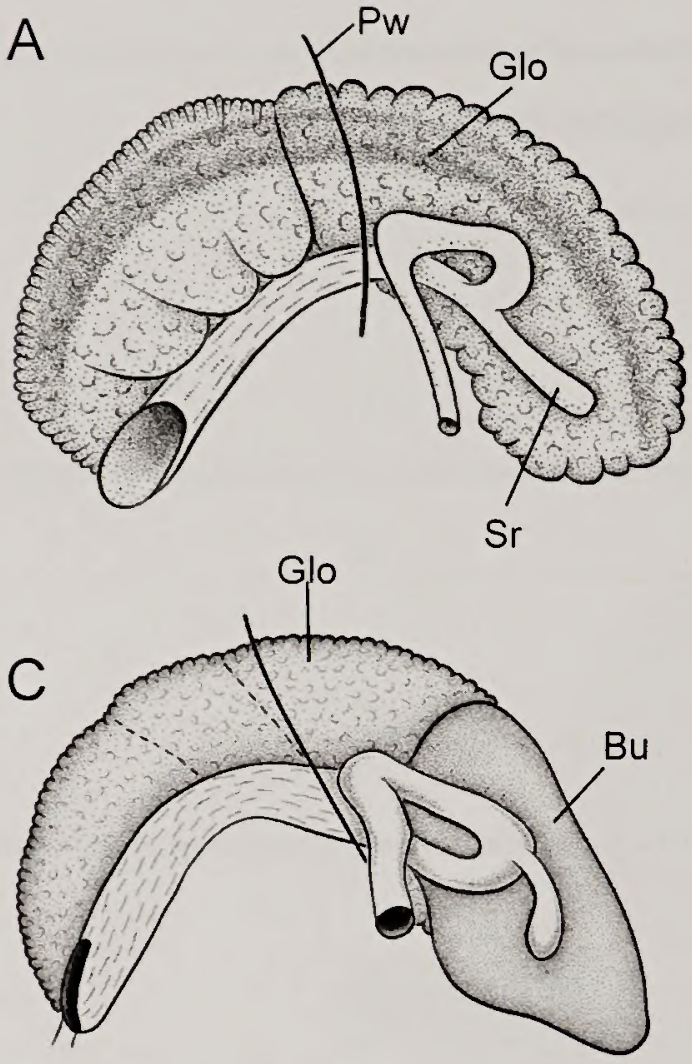

B
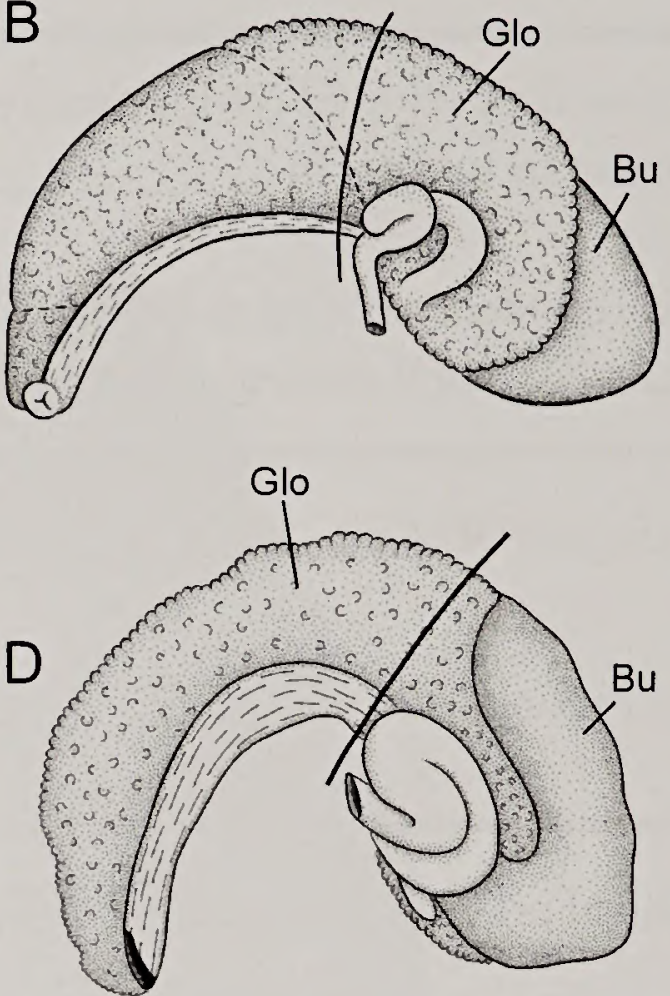

Figure 5.

Drawings of (female) glandular oviducts and associated structures (left side).

A. Taylorconcha serpenticola

B. Fluminicola ahjumawi.

C. Pyrgulopsis militaris.

D. Pristinicola hemphilli. Anterior to left. $\mathrm{Bu}$, bursa copulatrix; Glo, glandular oviduct; Pw, posterior wall of pallial cavity; $\mathrm{Sr}$, seminal receptacle.

5. Bursa copulatrix overlapping right side of albumen gland (Figure 5B); protoconch sculptured with spiral lines (Figure 6A)

Fluminicola

Bursa copulatrix overlapping left side of albumen gland (Figure 5C-D); protoconch surface wrinkled or pitted (Figure 6B)

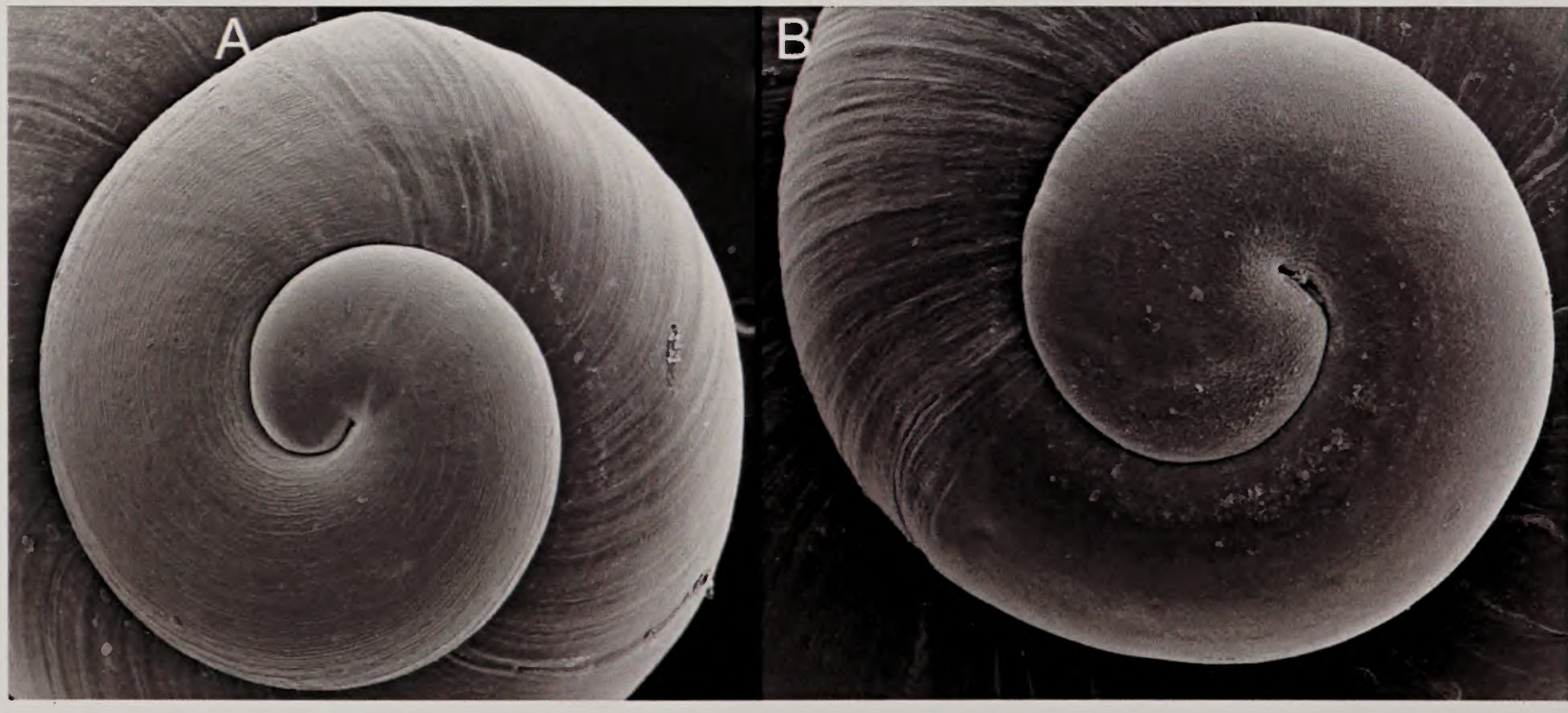

Figure 6.

Scanning electron micrographs showing sculpture on shell apical whorls.

A. Fluminicola gustafsoni.

B. Pyrgulopsis castaicensis. 
6. Shell near planispiral to turriform, rarely pupiform; whorls usually convex; operculum amber-colored (Figure 7A); penis rectangular to elongate $(<4 \mathrm{x}$ longer than wide); penial duct narrow (Figure 4E-F)

Shell pupiform; whorls near flat; operculum reddish (Figure 7B); penis vermiform ( $>6 \mathrm{x}$ longer than wide); penial duct wide (Figure $4 \mathrm{G}$ )

\section{Pristinicola}

Figure 7.

Photographs of opercula (dorsal aspect).

A. Pyrgulopsis orbiculata.

B. Pristinicola hemphilli.

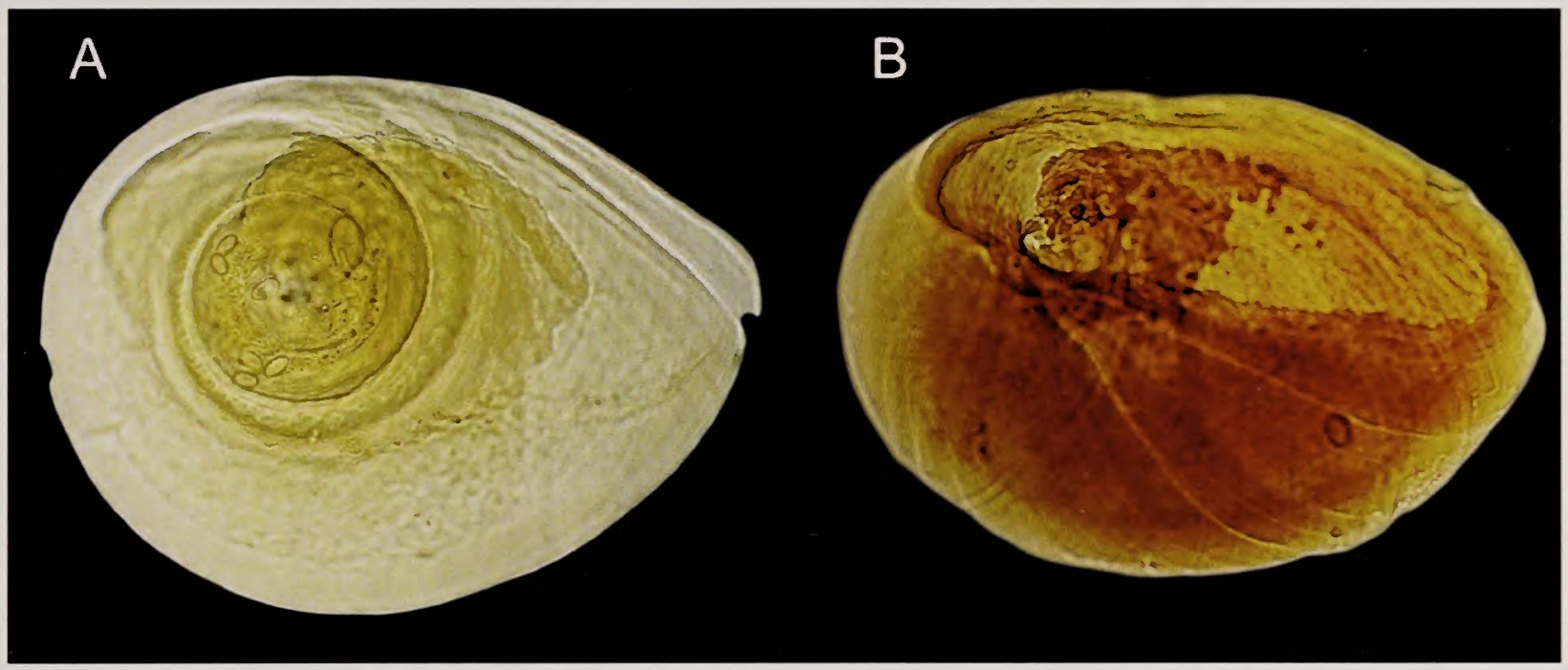

7. Penial surficial glands (glandular strips or pads) present (Figure 8A-C)

Penial surficial glands absent 8

Figure 8.

Drawings of penes

(A-B, D-F, dorsal side;

$C$, ventral side).

A. Pyrgulopsis militaris.

B. Pyrgulopsis perforata.

C. Pyrgulopsis fresti.

D. Littoridinops monroensis

E. Amnicola limosa.

F. Colligyrus convexus.

Distal edge to left.

Gp, glandular pad;

Gs, glandular strip;

$\mathrm{Pa}$, glandular papilla;

Pl, penial lobe;

Tg, tubular gland.
A

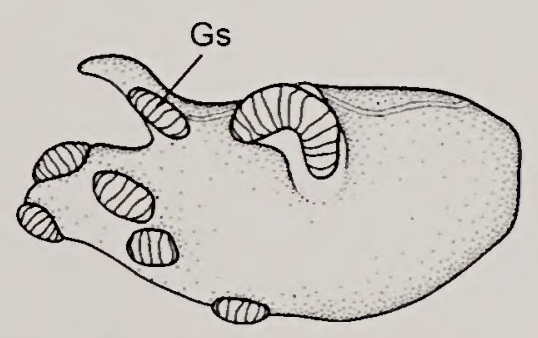

C
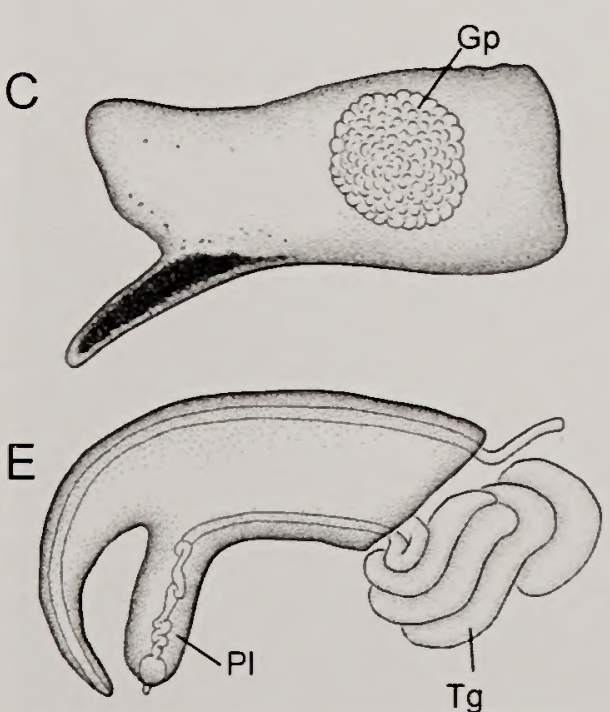

B
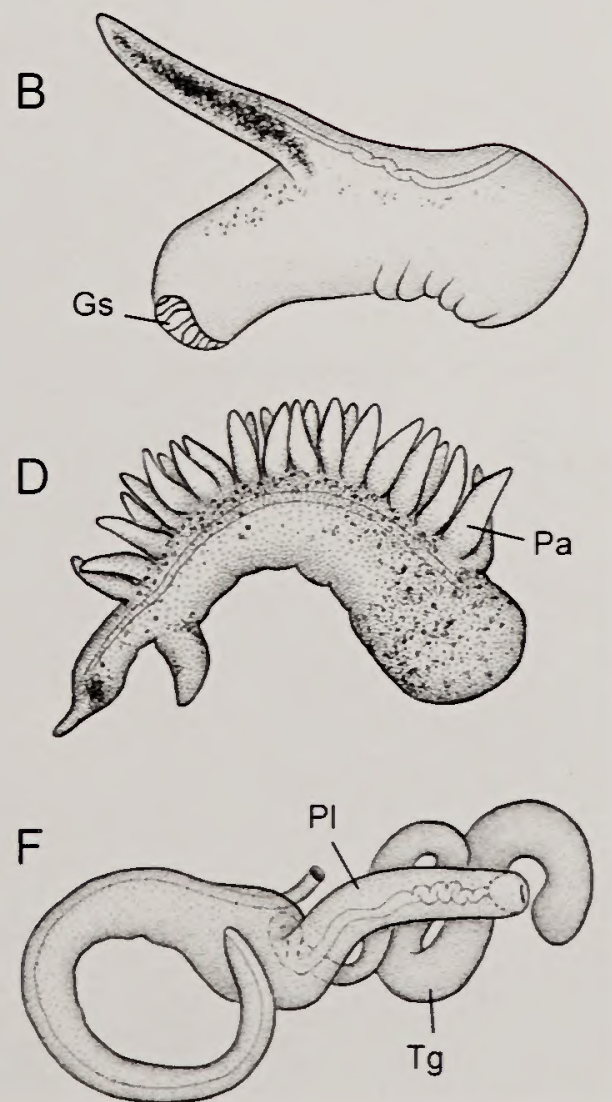
8. Penis has glandular papillae (Figure 8D)

Penis has an internal, tubular gland (Figure 8E-F) 9

9. Shell $3.0-4.5 \mathrm{~mm}$ tall; penial lobe medially positioned

(Figure 8E); bursa copulatrix large relative to albumen gland (Figure 9A)

Amnicola

Shell 1.3-3.3 mm tall; penial lobe basally positioned (Figure 8F); bursa copulatrix small relative to albumen gland

(Figure 9B-C) 10

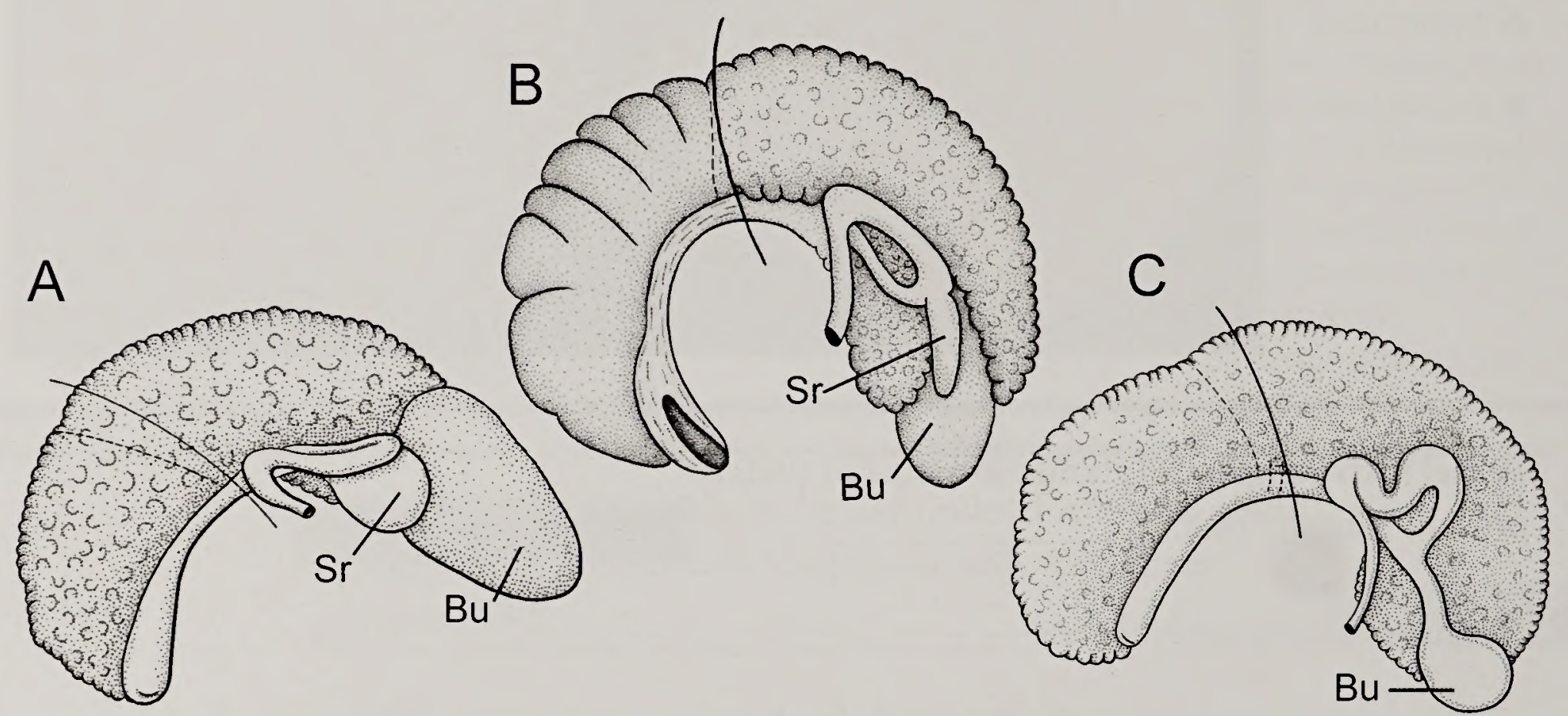

Figure 9. Female glandular oviducts of amnicolid snails.

A. Amnicola limosa. B. Colligyrus convexus

Anterior to left. C. Lyogyrus sp.

$\mathrm{Bu}$, bursa copulatrix; Sr, seminal receptacle

10. Females have two sperm pouches (bursa copulatrix, seminal receptacle) (Figure 9A-B)

Colligyrus

Females have one sperm pouch (bursa copulatrix)

(Figure 9C)

Lyogyrus 
11. Males absent in most populations; penial lobes absent

(Figure 10A); white smear often present on inner

side of operculum (Figure 11A, C)

\section{Potamopyrgus}

Males common (except in one species of Tryonia), penial lobes present (Figure 10B-D); white smear absent on inner side of operculum (Figure 11B)

Figure 10.

Drawings

of penes

(dorsal aspect)

Distal edge

to left.

A. Potamopyrgus

antipodarum

B. Tryonia

clathrata.

C. Eremopyrgus

eganensis.

D. Ipnobius

robustus.

A

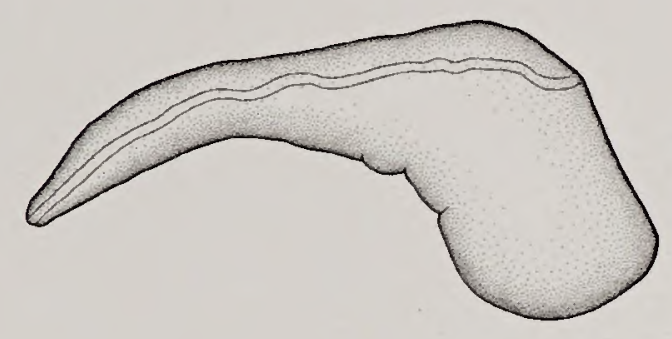

C

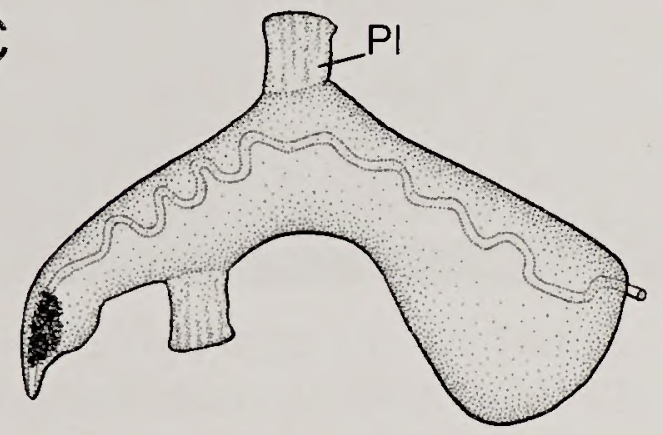

B

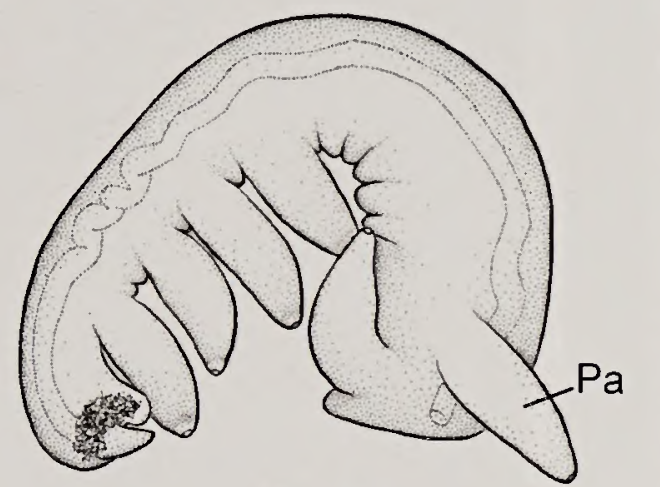

D

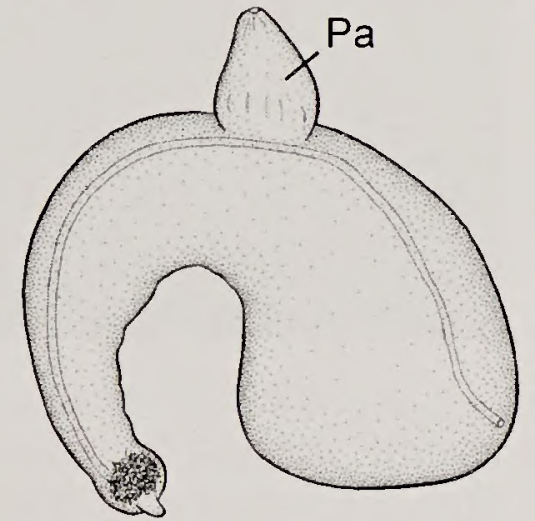

Figure 11.

Photographs of shells and opercula.

A: Potamopyrgus antipodarum.

B. Tryonia imitator.

C. Operculum (inner side), Potamopyrgus antipodarum. Ws, white smear.

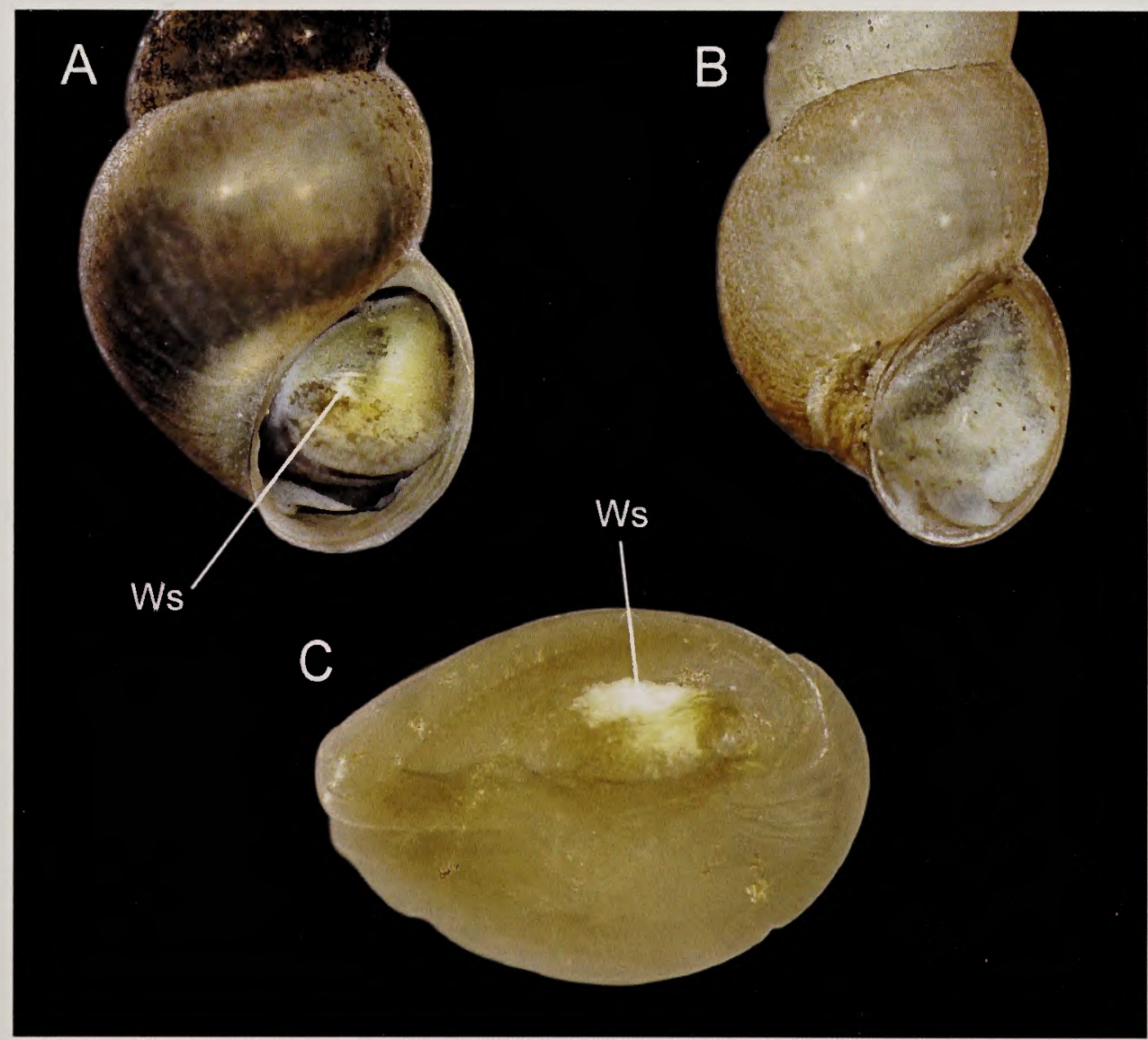


12. Penis has square-shaped lobe(s)

Penis has papillae (Figure 10B, D)

13. Penis has multiple papillae, including at least one positioned on inner edge (Figure 10B)

Penis has single papilla, positioned on outer edge

(Figure 10D)

Ipnobius 


\section{Species Checklist}

\section{Superfamily Truncatelloidea Gray, 1840}

\section{Family Amnicolidae Tryon, 1863}

Genus Amnicola Gould and Haldeman in Haldeman, 1840

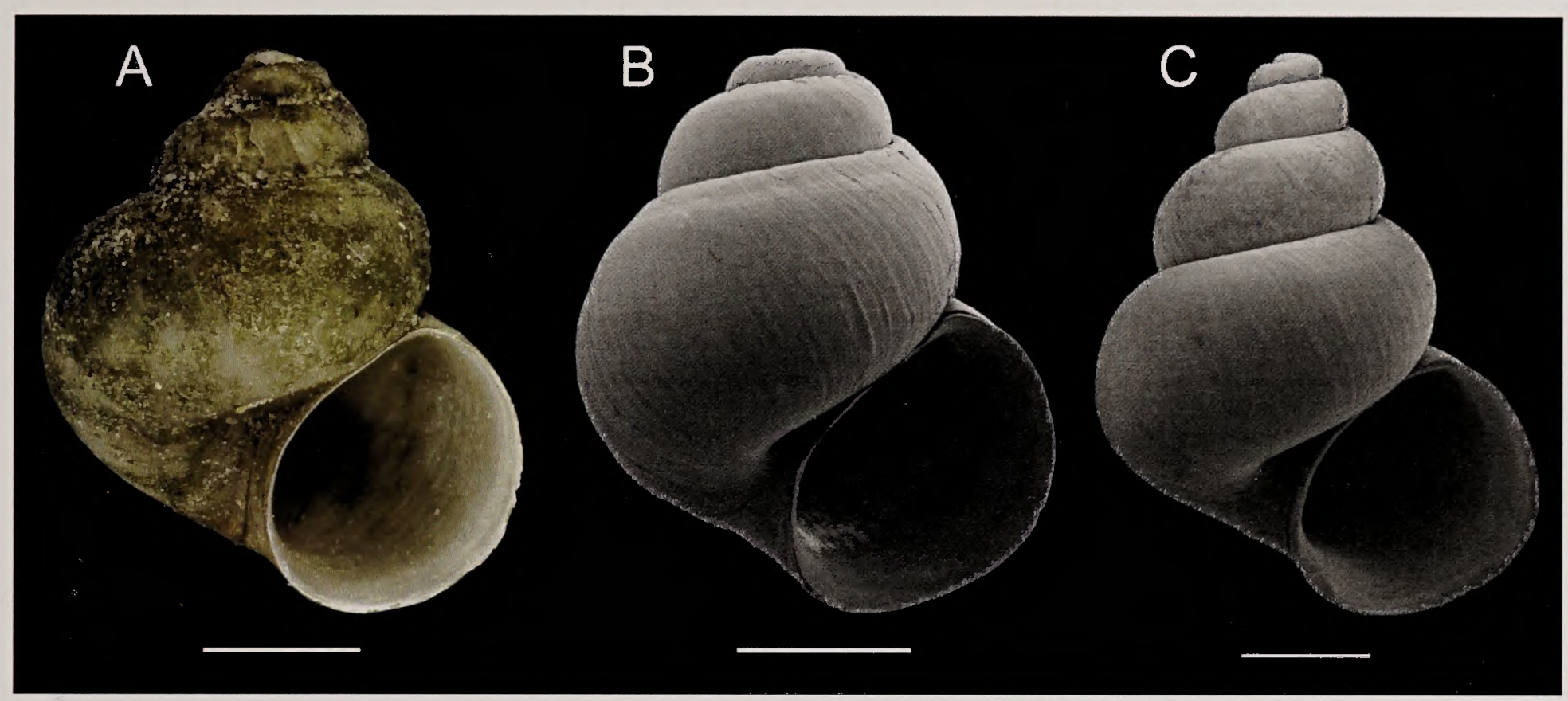

Figure 12. Amnicola limosa. A. McWenneger Slough, Flathead County, Montana (University of Minnesota Bell Museum of Natural History [BellMNH] 21425). B. Utah Lake, Utah County, Utah (USNM 47865). C. Curlew Lake, Ferry County, Washington (USNM 1256491). Scale bars, $1.0 \mathrm{~mm}$.

Amnicola Gould and Haldeman in Haldeman, 1840: 3 [type species, Paludina porata Say, 1821 (= Paludina limosa Say, 1817); subsequent designation by Herrmannsen 1846: 38].

Remarks: Amnicola (containing six species) lives in a variety of lotic and lentic habitats and is distributed in a large portion of eastern North America (north of Mexico). One congener (A. limosa) is found in the western United States.

\section{Amnicola limosa (Say, 1817)}

Paludina limosa Say, 1817: 125-126. Delaware and Schuylkill Rivers. Types have not been found.

Paludina porata Say, 1821: 174. Cayuga Lake [New York]. Lectotype, ANSP 283866; paralectotypes, ANSP 368398.

Amnicola ferruginea Calkins 1880: 6, unlabeled figure (on p. 6). Calumet River, Ill.

[Illinois]. Type has not been found. 
Amnicola orbiculata Lea, 1844: 34. Springfield, Ohio, and Schuylkill? [sic] near Philadelphia. Holotype, USNM 121342.

Common name: Mud amnicola.

Distribution: Widely ranging in eastern North America (Burch and Tottenham 1980; Clarke 1981); also found in several lakes in Montana and Washington (Liu et al. 2016). The historic population in Utah Lake appears to be extinct (Taylor and Bright 1987).

Taxonomy: Taylor and Bright (1987: fig. 8), Liu et al. (2016).

Remarks: The synonymy does not include the many (extralimital) subspecies of Amnicola limosa.

\section{Genus Colligyrus Hershler, 1999}

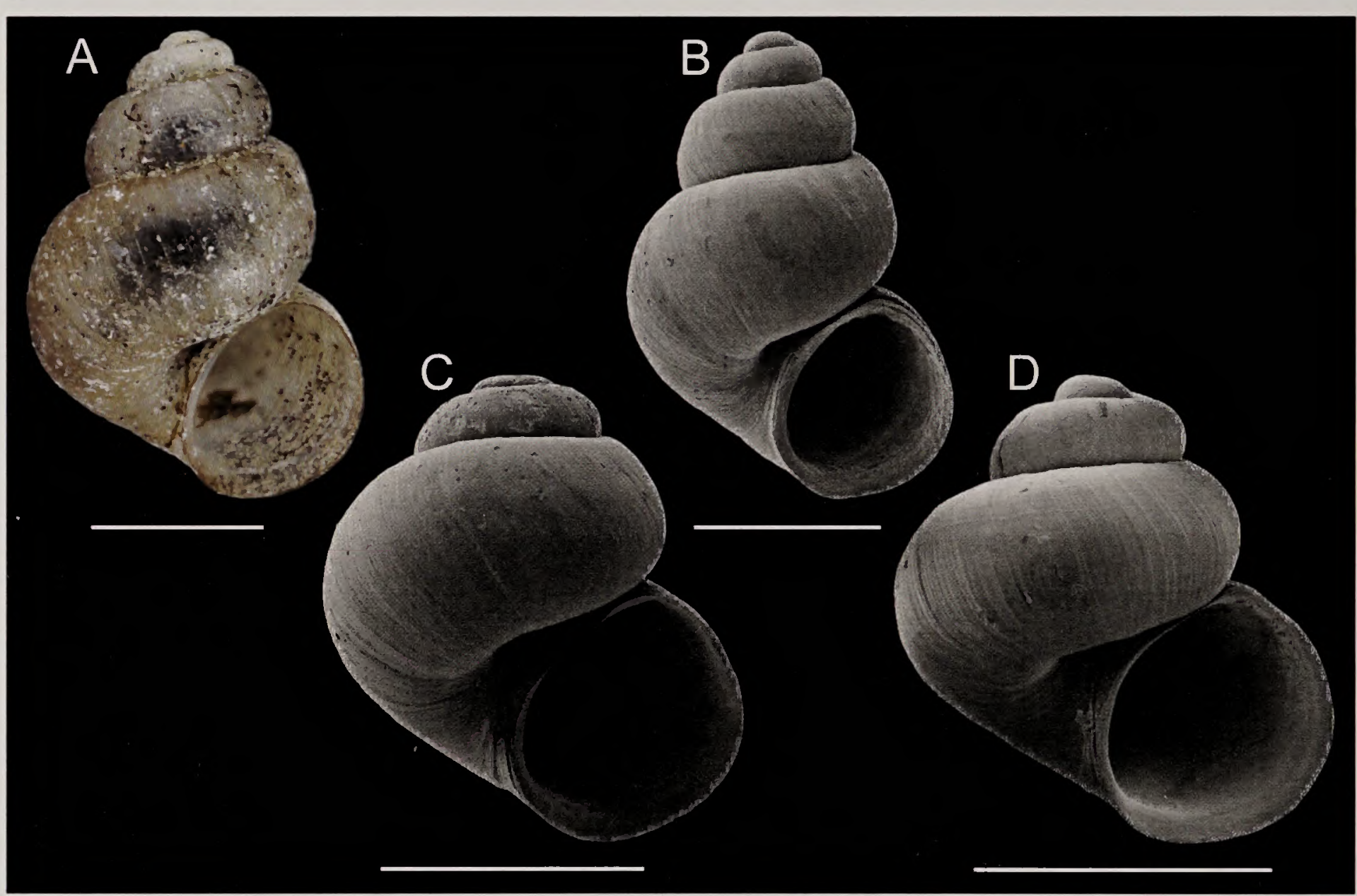

Figure 13. Colligyrus. A-B. C. greggi, springs along Cliff Creek, Sublette County, Wyoming (USNM 905410, USNM 883531, respectively). C. C. depressus, springs along Cricket Creek, Harney County, Oregon (USNM 860756 [paratype]). D. C. convexus, Lava Creek, Shasta County, California (USNM 1004536 [paratype]). Scale bars, $1.0 \mathrm{~mm}$.

Colligyrus Hershler, 1999: 306-308 [type species: Taylorconcha serpenticola Hershler, Frest, Johannes, Bowler and Thompson, 1994; original designation.] 
Remarks: Colligyrus is widely distributed in the northwestern United States and typically lives in springs and small streams. Molecular evidence suggests that there are undescribed congeners in the Klamath River (Hershler et al. 2003a) and Puget Sound (Liu et al. 2015a) basins.

Colligyrus convexus Hershler, Frest, Liu, and Johannes, 2003

Colligyrus convexus Hershler, Frest, Liu, and Johannes, 2003a: 278-280, 282, figs. 2-3, 4a, 5. Lava Creek at and west of Island Road bridge near mouth to Eastman Lake, Lava Creek Ranch, north side of The Island, about $8.3 \mathrm{~km}$ north of Glenburn, Shasta County, California. Holotype, USNM 1004535; paratypes, USNM 1004536.

Common name: Canary duskysnail.

Distribution: Fall River, Hat Creek, and lower Burney Creek drainages (Pit River basin), California (Hershler et al. 2003a).

\section{Colligyrus depressus Hershler, 1999}

Colligyrus depressus Hershler, 1999: 311, 312, 314, 316, figs. 2E-F, 3B, 6. Unnamed springs, Cricket Creek, Silvies River drainage, Harney County, Oregon. Holotype, USNM 883876; paratypes, USNM 860756.

Common name: Harney Basin duskysnail.

Distribution: Known only from the type locality.

\section{Colligyrus greggi (Pilsbry, 1935)}

Hydrobia greggi Pilsbry, 1935: 93-94, fig. 2. Cliff Creek Canyon, a fork of Hoback Canyon, about 29 miles [46.7 km] south of Jackson, Wyoming, in the Snake River drainage. Lectotype, ANSP 163812; paralectotypes, ANSP 375735.

Common name: Rocky Mountain duskysnail.

Distribution: Upper Snake River basin (Idaho, Wyoming), northeastern Great Basin (Idaho, Utah), lower Columbia River basin (Oregon, Washington) (Hershler 1999; Liu et al. 2015a).

Taxonomy: Hershler (1999), Liu et al. (2015a). 


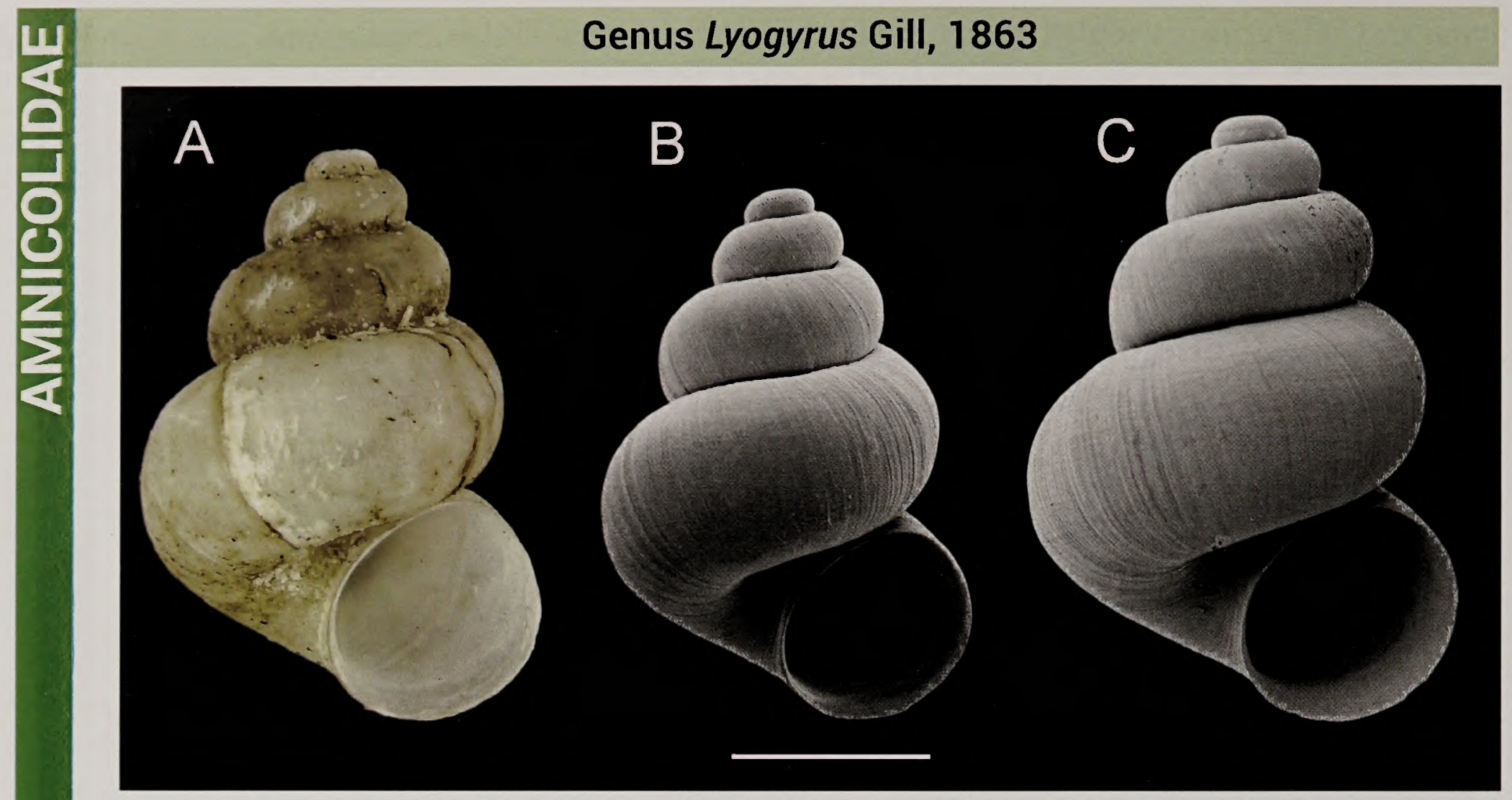

Figure 14. Lyogyrus sp. A. Browns Lake, Powell County, Montana (USNM 1263003). B. Fish Lake, Chelan County, Washington (USNM 1258915).

C. Upsata Lake, Powell County, Montana (USNM 1262996). Scale bar, $1.0 \mathrm{~mm}$.

Lyogyrus Gill, 1863: 34 [type species: Valvata pupoidea Gould, 1839; original designation].

Remarks: Lyogyrus (containing nine species) is widely distributed in a variety of freshwater and brackish water habitats in North America from the Mississippi River basin eastward. Additionally, one congener of uncertain species status is found in several lakes in the northwestern United States. Lyogyrus was frequently treated in the 20th century literature as a subgenus of Amnicola, but is currently recognized as a distinct genus based on morphological and molecular evidence (Thompson and Hershler 1991; Liu et al. 2015a).

\section{Lyogyrus sp.}

Lyogyrus sp. - Liu et al. 2016: 467-469, figs. 6-8.

Common name: Masked duskysnail.

Distribution: Several lakes in northern Washington and Montana (Liu et al. 2015a).

Remarks: The taxonomic status of this snail is uncertain pending further study of the poorly known eastern species of Lyogyrus. 


\section{Family Cochliopidae Tryon, 1866}

\section{Genus Eremopyrgus Hershler, 1999}

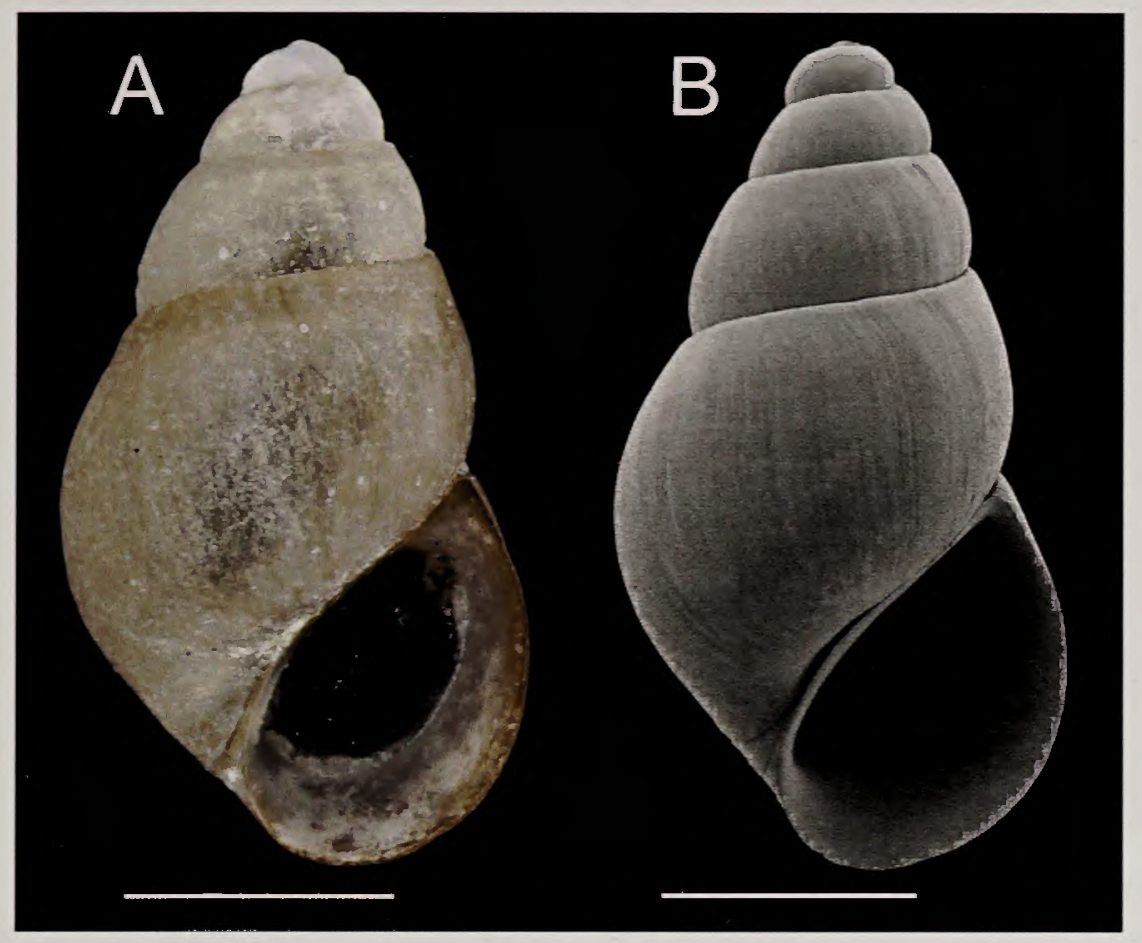

Figure 15. Eremopyrgus eganensis. A-B. Spring northwest of Clark Spring, Steptoe Valley, White Pine County, Nevada (USNM 883529, USNM 860759 [paratype], respectively). Scale bars, $1.0 \mathrm{~mm}$.

Eremopyrgus Hershler, 1999: 326-328 [type species: Eremopyrgus eganensis Hershler, 1999; original designation].

Remarks: Eremopyrgus is composed of two locally endemic, spring-dwelling species in Nevada and northeastern Mexico (Hershler et al. 2002).

\section{Eremopyrgus eganensis Hershler, 1999}

Eremopyrgus eganensis Hershler, 1999: 328, figs. 3C, 12, 13A-C. Spring northwest of Clark Spring, Steptoe Valley, White Pine County, Nevada. Holotype, USNM 874692; paratypes, USNM 860759.

Common name: Steptoe hydrobe.

Distribution: Several springs in Steptoe Valley, Nevada. 


\section{Genus Ipnobius Hershler, 2001}

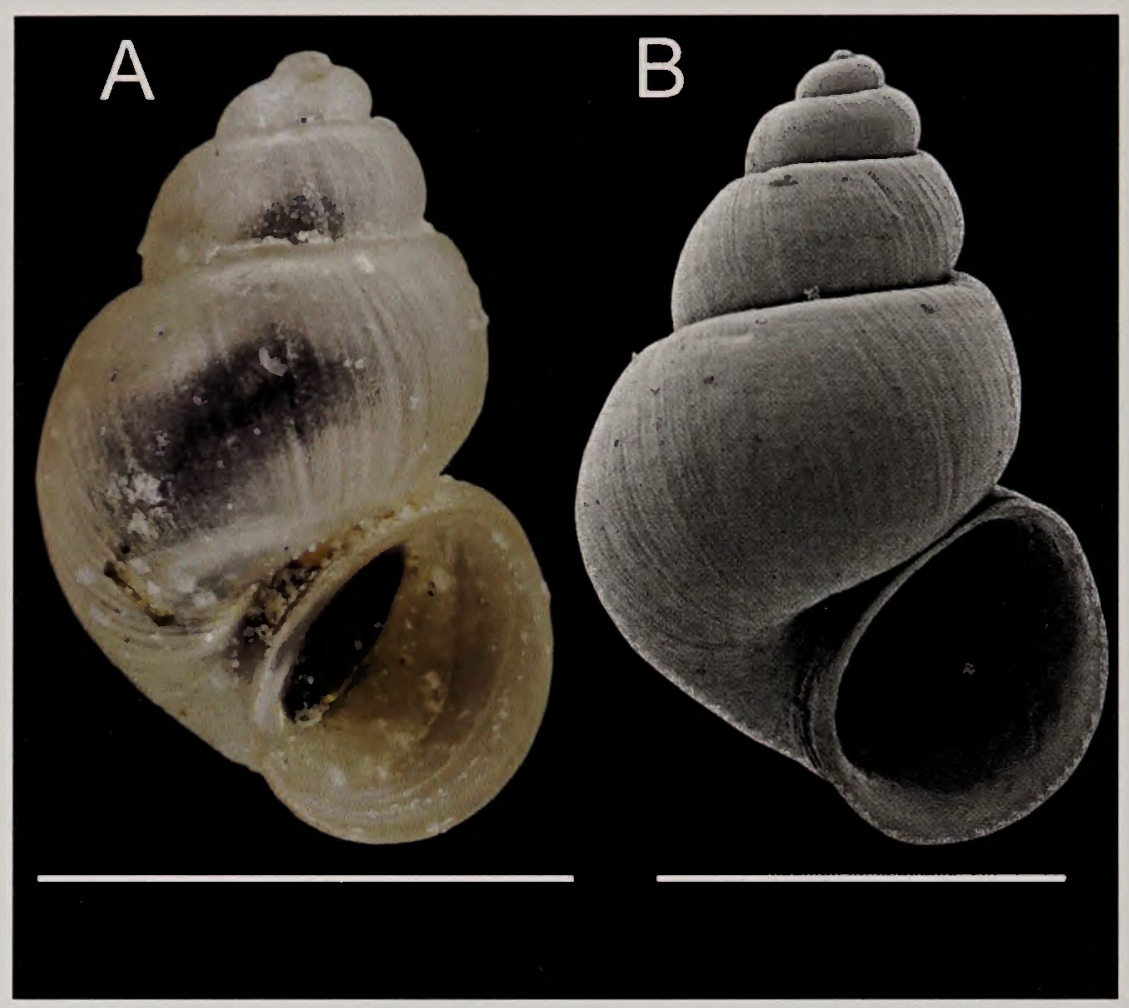

Figure 16. Ipnobius robustus. A-B. Nevares Springs, Death Valley, Inyo County, California (USNM 883311, USNM 853557 [paratype], respectively). Scale bars, $1.0 \mathrm{~mm}$.

Ipnobius Hershler, 2001: 19 [type species, Tryonia robusta Hershler, 1989; original designation].

Remarks: Ipnobius is a monotypic genus that is distributed in thermal springs in Death Valley, California.

\section{Ipnobius robustus Hershler, 1989}

Tryonia robusta Hershler, 1989: 208-211, figs. 51d, 55-58. Nevares Springs, Death Valley, Inyo County, California. Holotype, USNM 860411; paratypes, USNM 853557.

Common name: Robust tryonia.

Distribution: Two spring complexes in central Death Valley, California. 


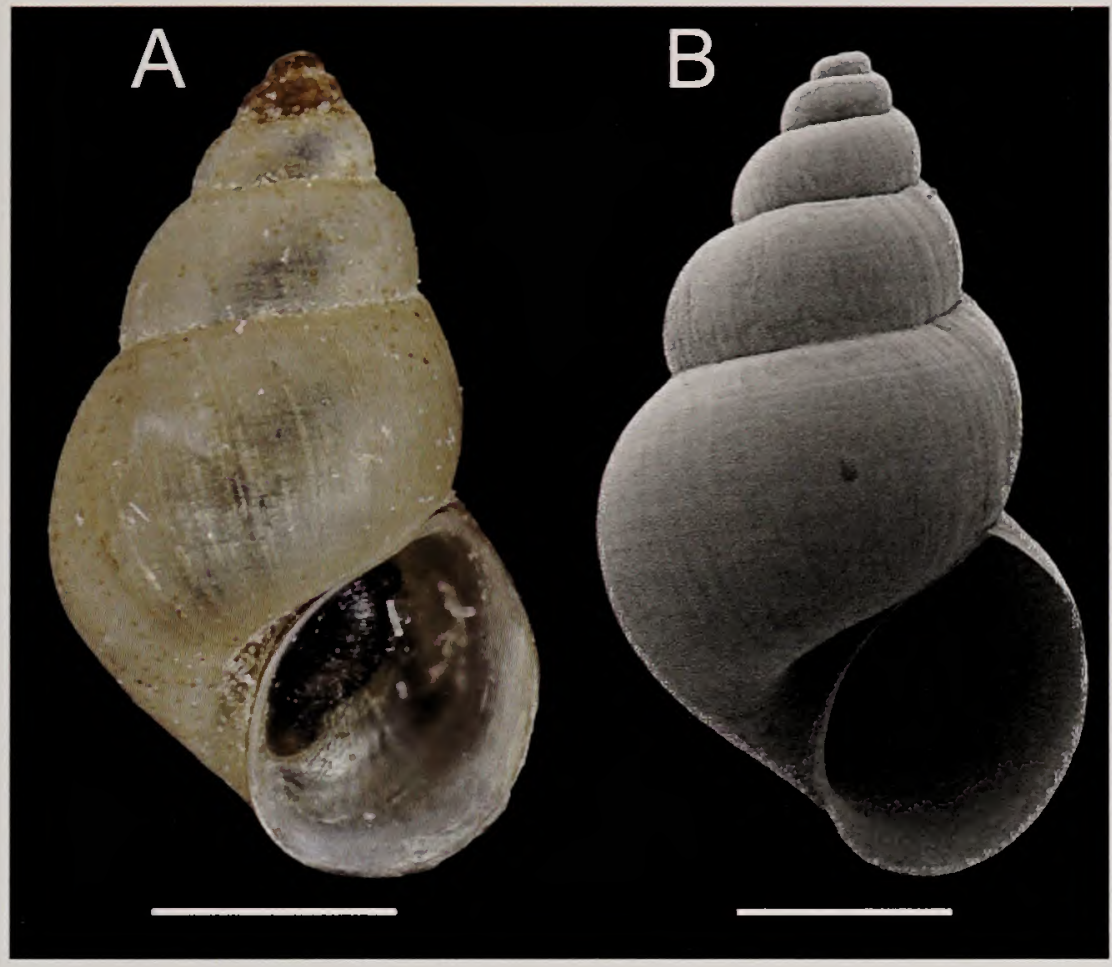

Figure 17. Littoridinops monroensis. A. Sulphur Springs, Hillsborough County, Florida (USNM 874865). B. Suisun Bay (San Francisco Estuary), Contra Costa County, California (USNM 1087202). Scale bars, $1.0 \mathrm{~mm}$.

Littoridinops Pilsbry, 1952: 51 [type species: Amnicola tenuipes Couper in Haldeman, 1844; original designation].

Remarks: Littoridinops (containing four species) is widely distributed along the North American Atlantic Coast from New Jersey to Campeche, Mexico; also found on several islands in the West Indies (Hershler and Thompson 1992; Vázquez et al. 2012). Members of this genus live in estuarine coastal waters and occasionally in inland freshwater habitats.

\section{Littoridinops monroensis (Frauenfeld, 1863)}

Hydrobia monroensis Frauenfeld, 1863: 1023. Lakeman Rok, Florida [possibly referring to Lake Monroe, Volusia County]. Lectotype, NMW; paralectotypes, NMW (per Thompson 1968).

Common name: Cockscomb hydrobe.

Distribution: Florida, Bahama Islands, and Cuba (Thompson 1968; Vázquez et al. 2012). Introduced to San Francisco Bay (Hershler et al. 2007a).

Taxonomy: Hershler et al. (2007a). 


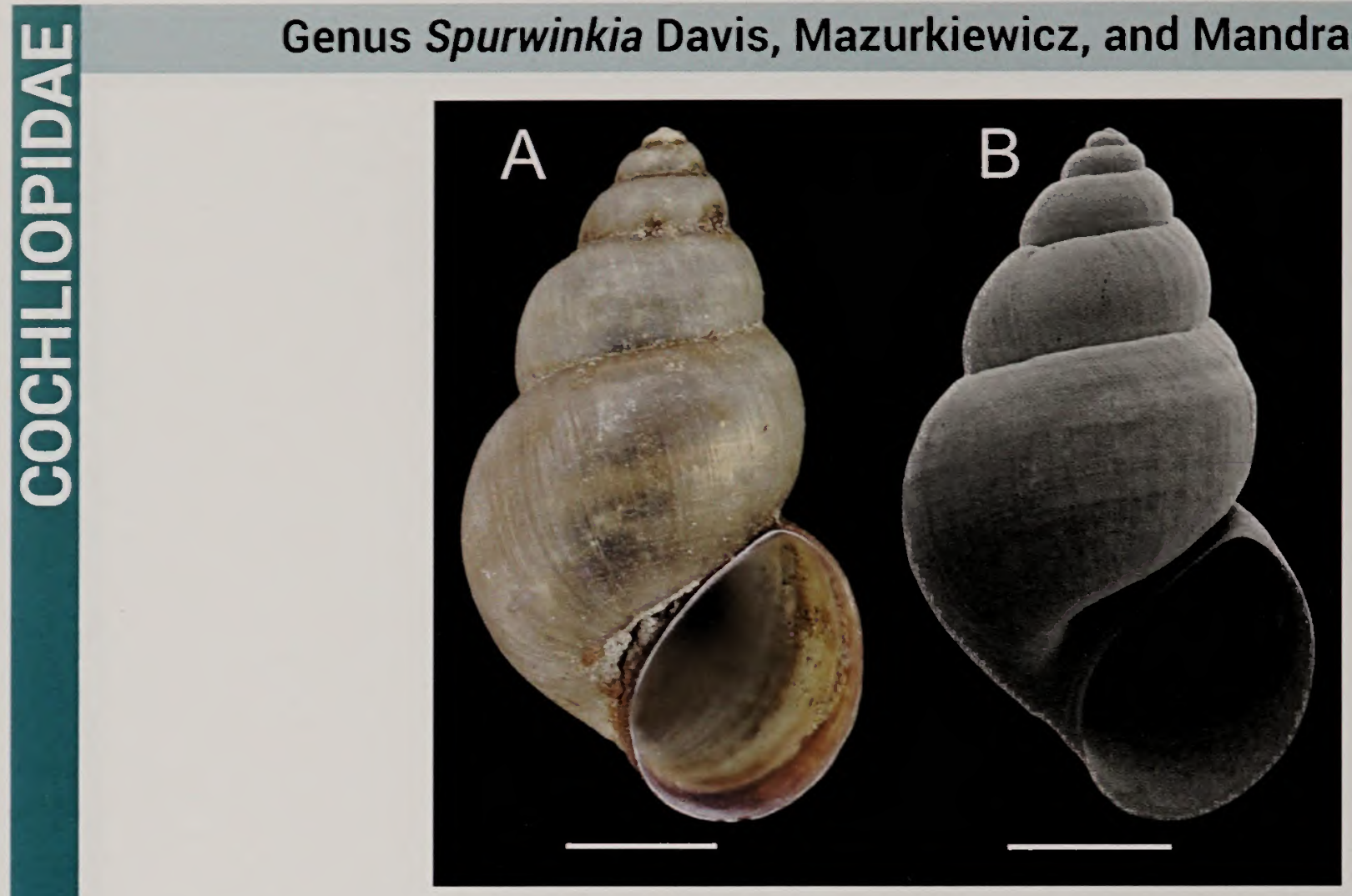

Figure 18. Spurwinkia salsa. A. Near Harvard Bridge, Boston, Massachusetts (USNM 435954). B. Eden Landing (San Francisco Estuary), Alameda County, California (USNM 1120373). Scale bars, $1.0 \mathrm{~mm}$.

Spurwinkia Davis, Mazurkiewicz, and Mandracchia, 1982: 162ff [type species:

Hydrobia salsa Pilsbry, 1905; original designation].

Remarks: Spurwinkia is a monotypic genus that is distributed in estuarine habitats along the North American Atlantic Coast.

\section{Spurwinkia salsa (Pilsbry, 1905)}

Paludestrina salsa Pilsbry, 1905: 90-91, pl. 3: fig. 10. Cohasset, Massachusetts.

Lectotype, ANSP 90445; paralectotypes, ANSP 461848.

Common name: Saltmarsh hydrobe.

Distribution: Widely ranging along the western Atlantic coast from New Brunswick to Georgia (Hershler and Thompson 1992; McAlpine et al. 2005). Introduced to San Francisco Bay (Hershler et al. 2015a).

Taxonomy: Hershler et al. (2015a) 

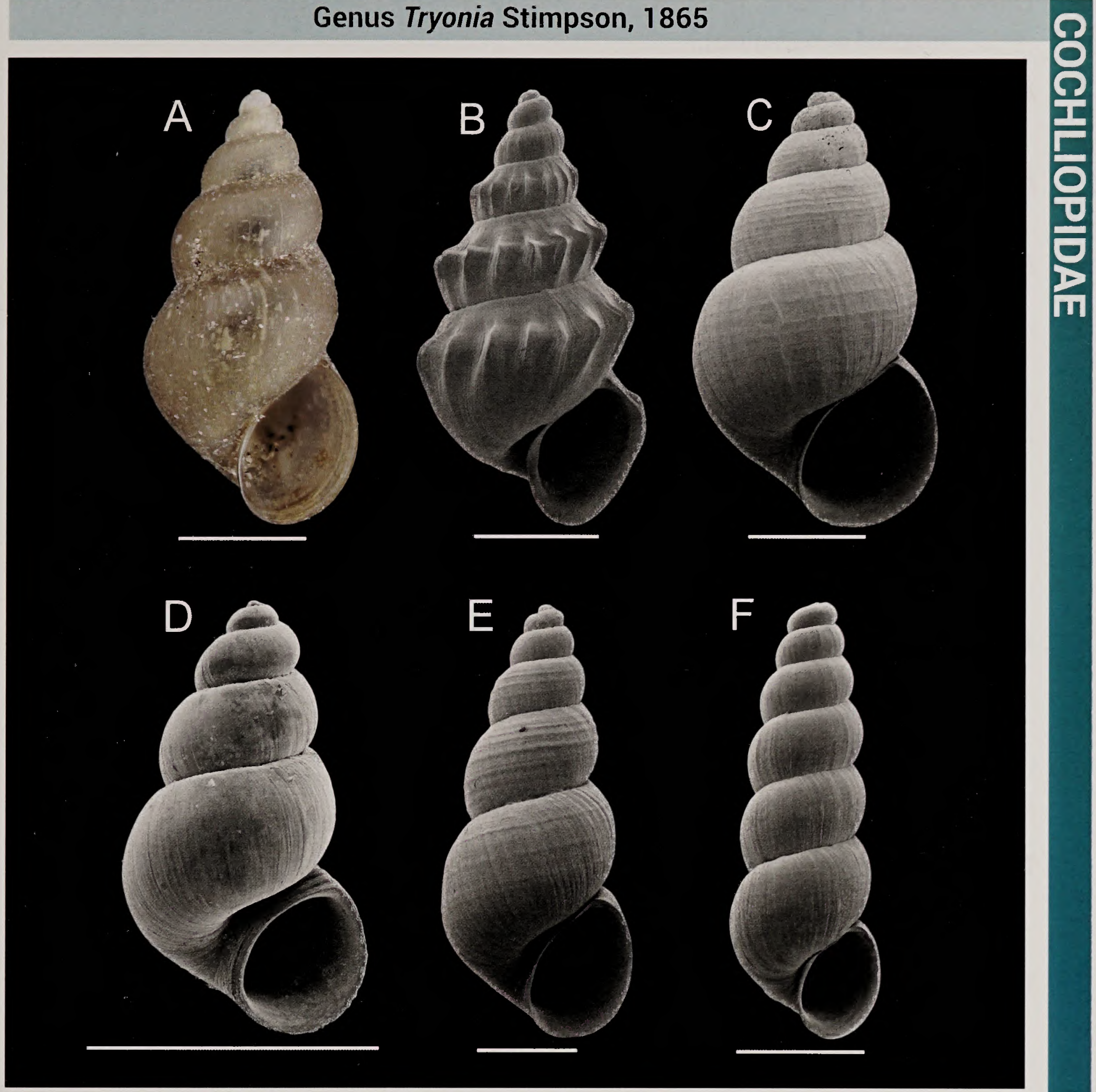

Figure 19. Tryonia. A. T. angulata, Big Spring, Ash Meadows, Nye County, Nevada (USNM 883304). B. T. clathrata, Cardy Lamb Spring, Moapa Valley, Clark County, Nevada (USNM 874355). C. T. imitator, Morro Estuary, San Luis Obispo County, California (USNM 892057). D. T. ericae, North Scruggs Spring, Ash Meadows, Nye County, Nevada (USNM 859163 [paratype]). E. T. porrecta, southern Suisun Bay (San Francisco Estuary), Contra Costa County, California (USNM 1087204). F. T. monitorae, Hot Springs, Potts Ranch, Monitor Valley, Nye County, Nevada (USNM 860760 [paratype]). Scale bars, $1.0 \mathrm{~mm}$.

Tryonia Stimpson, 1865: 54 [type species: Tryonia clathrata Stimpson, 1865; original designation].

Calipyrgula Pilsbry, 1934: 15 [type species: Calipyrgula carinifer Pilsbry, 1934; original designation]. 
Durangonella Morrison, 1945: 18 [type species: Hydrobia seemani Frauenfeld, 1863; original designation].

Hyalopyrgus Thompson, 1968: 43-46 [type species: Bythinella aequicostata Pilsbry, 1890; original designation].

Paupertryonia Taylor, 1987: 38 [type species: Potamopyrgus cheatumi Pilsbry, 1935; original designation].

Remarks: Tryonia is a relatively large genus (33 species) that is widely distributed in southwestern North America and is also found in the Florida Peninsula. Fourteen congeners are distributed in drainages of the western United States. Tryonia usually inhabits thermal springs; a few species live in lakes and/or coastal waters. Molecular evidence suggests that Tryonia is paraphyletic relative to the monotypic northern Mexican genus Minckleyella; these taxa are currently recognized as distinct because of the differences in their female reproductive anatomy (Hershler et al. 2011).

\section{Tryonia angulata Hershler and Sada, 1987}

Tryonia angulata Hershler and Sada, 1987: 810-811, 814-817, figs. 39a, 40-41, 42a,d, 43. Fairbanks Spring, Ash Meadows, Nye County, Nevada. Holotype, USNM 859151; paratypes, UF 93960, USNM 859152.

Common name: Sportinggoods tryonia.

Distribution: Three large spring pools in Ash Meadows, Nevada.

Taxonomy: Hershler (2001).

\section{Tryonia clathrata Stimpson, 1865}

Tryonia clathrata Stimpson, 1865: 54, pl. 8, fig. 1. Basin of the Colorado Desert [in error, probably Moapa Valley, Nevada; Hershler 1999]. Lectotype (and paralectotypes), ANSP 27969.

Common name: Grated tryonia.

Distribution: White River drainage, Nevada (Hershler 2001).

Taxonomy: Hershler (2001).

\section{Tryonia elata Hershler and Sada, 1987}

Tryonia elata Hershler and Sada, 1987: 831, figs. 39b, 42c, 53e-h, 56. Point of Rocks Springs, Ash Meadows, Nye County, Nevada. Holotype, USNM 859159; paratypes, UF 93963, USNM 859160.

Common name: Point of Rocks tryonia.

Distribution: Two small springs at Point of Rocks, Ash Meadows, Nevada.

Taxonomy: Hershler (2001). 
Tryonia ericae Hershler and Sada, 1987: 826-831, figs. 39c-d, 42f,i, 53a-d, 54. North

Scruggs Spring, Ash Meadows, Nye County, Nevada. Holotype, USNM 859162; paratypes, UF 93962, USNM 859163.

Common name: Minute tryonia.

Distribution: Two closely proximal springs in Ash Meadows, Nevada.

Taxonomy: Hershler (2001).

\section{Tryonia gilae Taylor, 1987}

Tryonia gilae Taylor, 1987: 36-37, fig. 17. Unnamed spring on north side of Gila River about $2 \mathrm{mi}[3.2 \mathrm{~km}]$ north of Bylas, Graham County, Arizona. Holotype, LACM 2187; paratypes, UTEP 10063.

Tryonia gilae Hershler in Hershler and Landye, 1988: 43, 47-49, 58, figs. 14c,f, 39a-e, 40, 41a-c, 42, 43d-i, 44-45, 46a, 47b. Small spring near Bylas, Graham County, Arizona. Holotype, USNM 859059; paratypes, USNM 859060.

Common name: Gila tryonia.

Distribution: Springs along the north side of the Gila River between Bylas and Pima, Arizona.

Taxonomy: Hershler (2001).

Remarks: Tryonia gilae Hershler is both a junior primary homonym and junior subjective synonym of Tryonia gilae Taylor.

\section{Tryonia imitator (Pilsbry, 1899)}

Paludestrina imitator Pilsbry, 1899: 124. Santa Cruz, California. Lectotype, ANSP 6270; paralectotypes, ANSP 457182.

Paludestrina curta Arnold, 1903: 305, pl. VIII: fig. 2. San Pedro bluffs [California], Upper San Pedro Series [Pleistocene]. Holotype, USNM 162542.

Common name: Mimic tryonia.

Distribution: Widely ranging along the central and southern California coast (Taylor 1981).

Taxonomy: Hershler (2001). 
Tryonia infernalis Hershler, Liu, and Simpson, 2015b: 114-116, figs. 4-5. Blue Point Spring, Clark County, Nevada. Holotype, USNM 883884; paratypes, USNM 1266143.

Common name: Blue Point tryonia [name newly introduced herein].

Distribution: Found only at the type locality.

\section{Tryonia margae Hershler, 1989}

Tryonia margae Hershler, 1989: 202-205, figs. 48-50, 51a. (Upper) warm spring on limestone bench, Grapevine Springs, Death Valley, California. Holotype, USNM 860408; paratypes, USNM 857952.

Common name: Grapevine Springs elongate tryonia.

Distribution: Found only at the type locality and a second, closely proximal spring. Taxonomy: Hershler (2001).

\section{Tryonia monitorae Hershler, 1999}

Tryonia monitorae Hershler, 1999: 332, 334, figs. 3D, 13D-G, 15. Hot Springs, Potts Ranch, Monitor Valley, Nye County, Nevada. Holotype, USNM 892046; paratypes, USNM 860760.

Common name: Monitor tryonia.

Distribution: Known only from the type locality.

Taxonomy: Hershler (2001).

\section{Tryonia porrecta (Mighels, 1848)}

Paludina porrecta Mighels, 1848: 22. Oahu [Hawaii]. Type has not been found [however, NHMUK 1995123 may be a syntype lot; Hershler 2001].

Amnicola protea Gould, 1855: 129-130. Colorado Desert (Gran Jornado). Lectotype, USNM 121074; paralectotypes, USNM 27906, USNM 860867.

Melania exigua Conrad, 1855: 269. Colorado Desert, California. Lectotype (and paralectotypes), ANSP 27965.

Pyrgulopsis imminens Taylor, 1950: 30-31, figs. 4-6. Shore of Salton Sea by Fish Springs (= Desert Shores), Imperial County, California. Holotype, SBMNH 35497; paratypes, SBMNH 35498, SBMNH 35499, USNM 613967.

Pyrgulopsis blakeana Taylor, 1950: 31-32, fig. 7. Holotype, SBMNH 35500; paratypes, SBMNH 35501, SBMNH 35502, USNM 613966.

Pyrgulopsis cahuillarum Taylor, 1950: 31-32, fig. 7. Holotype, SBMNH 35503. 
Common name: Desert tryonia.

Distribution: Lower Colorado River basin (Arizona, California, Mexico), Great Basin (Nevada, Utah), San Francisco Bay (California), Hawaii. The populations in San Francisco Bay (Hershler et al. 2007a) and artificial lakes in Phoenix (Hershler et al. 2015a) may have been introduced. (The Hawaiian population could be native or prehistorically introduced; Cowie 1997.)

Taxonomy: Hershler (2001), Hershler et al. (2007a).

Remarks: Most populations of $T$. porrecta are parthenogenetic and entirely composed of females (Hershler et al. 1999a; Hershler et al. 2005); one of the San Francisco Bay populations contains males (Hershler et al. 2007a).

\section{Tryonia quitobaquitae Hershler in Hershler and Landye, 1988}

Tryonia quitobaquitae Hershler in Hershler and Landye, 1988: 50, figs. 39f-h, 41df, 43a-c, 46a, 47a. Quitobaquito Springs, Organ Pipe [Cactus] National Monument, Pima County, Arizona. Holotype, USNM 859061; paratypes, USNM 859062.

Common name: Quitobaquito springsnail.

Distribution: Two closely proximal springs in the Rio Sonoyta basin, southern Arizona.

Taxonomy: Hershler (2001).

\section{Tryonia rowlandsi Hershler, 1989}

Tryonia rowlandsi Hershler, 1989: 211-215, figs. 51b, 59-60. Grapevine Springs, Grapevine Mountains, Death Valley, Inyo County, California. Holotype, USNM 860409; paratypes, USNM 857953.

Common name: Grapevine Springs squat tryonia.

Distribution: Found only at the type locality.

Taxonomy: Hershler (2001).

\section{Tryonia salina Hershler, 1989}

Tryonia salina Hershler, 1989: 215-216, figs. 51e, 61-62. Spring brook in Cottonball Marsh, Death Valley, Inyo County, California. Holotype, USNM 860410; paratypes, USNM 853556.

Common name: Cottonball Marsh tryonia.

Distribution: Several springs in Cottonball Marsh, Death Valley (California).

Taxonomy: Hershler (2001). 


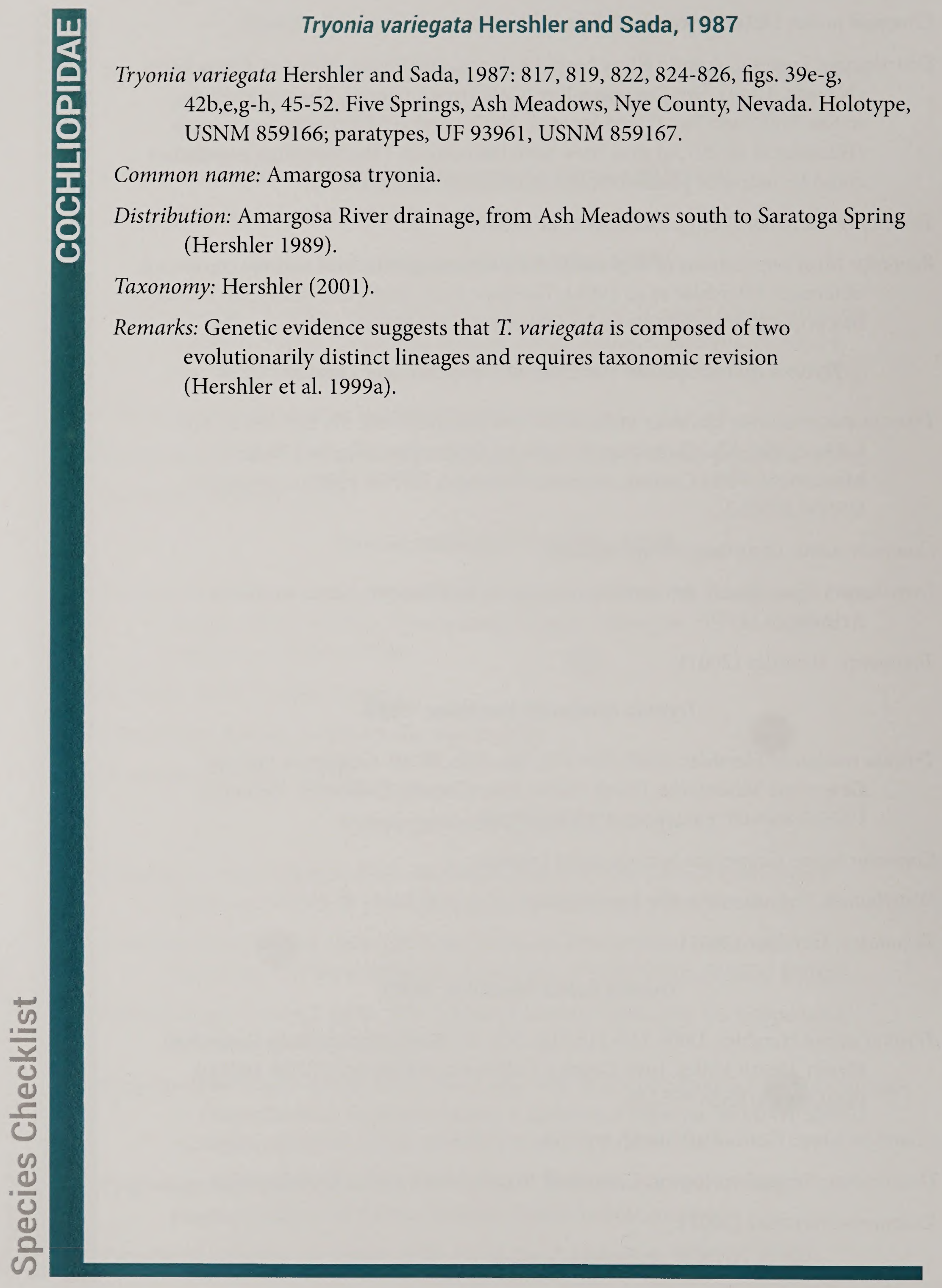


Family Hydrobiidae Stimpson, 1865

Subfamily Nymphophilinae Taylor, 1966

\section{Genus Pyrgulopsis Call and Pilsbry, 1886}

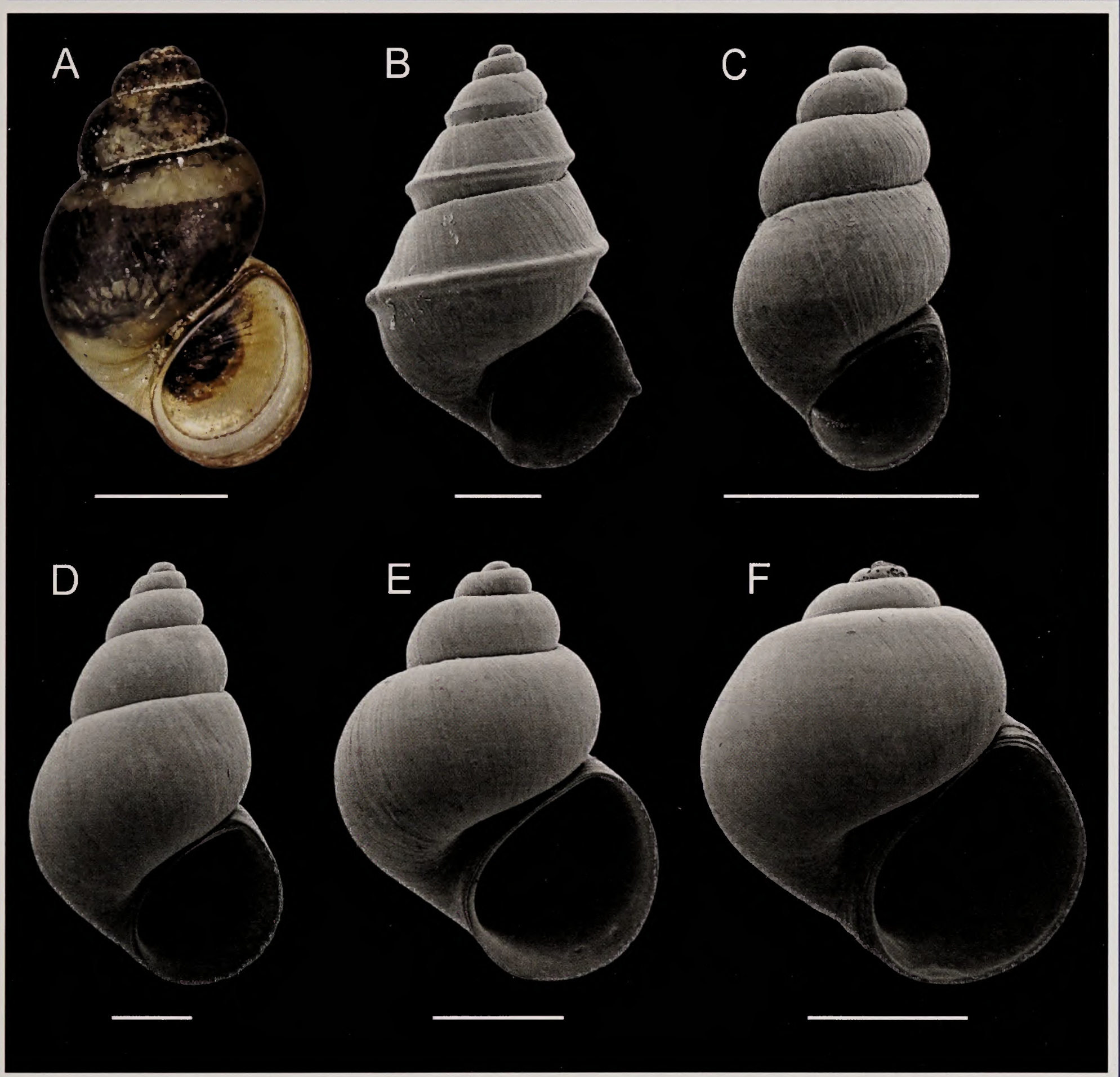

Figure 20. Pyrgulopsis. A. P. californiensis, Grapevine Spring, Anza-Borrego Desert State Park, San Diego County, SBMNH 4349. B. P. nevadensis, Pyramid Lake, Washoe County, Nevada (USNM 590364). C. P. dixensis, spring in Dixie Valley, Pershing County, Nevada (USNM 860688 [paratype]). D. P. robusta, Snake River, north of Jackass Butte, Elmore County, Idaho (ALBRCIDA 7568). E. P. aardahli, spring at Bramlette Ranch, Benton Valley, Mono County, California (USNM 857951 [paratype]). F. P. merriami, Ash Spring, Pahranagat Valley, Lincoln County, Nevada (USNM 873395). Scale bars, $1.0 \mathrm{~mm}$. 
Pyrgulopsis Call and Pilsbry, 1886: 9-10 [type species: Pyrgula nevadensis Stearns, 1883; original designation].

Fontelicella Gregg and Taylor, 1965: 103-104 [type species: Fontelicella californiensis Gregg and Taylor, 1965; original designation].

Natricola Gregg and Taylor, 1965: 108-109 [type species: Pomatiopsis robusta Walker, 1908; original designation].

Microamnicola Gregg and Taylor, 1965: 109 [type species: Amnicola micrococcus Pilsbry in Stearns, 1893; original designation].

Savaginius Taylor, 1966b: 130 [type species: Paludestrina nanna Chamberlain and Berry, 1933; original designation].

Nymphophilus Taylor, 1966a: 199-203 [type species: Nymphophilus minckleyi Taylor, 1966a; original designation].

Mexistiobia Hershler, 1985: 46-47 [type species: Mexistiobia manantiali Hershler, 1985; original designation].

Apachecoccus Taylor, 1987: 32 [type species: Apachecoccus arizonae Taylor, 1987; original designation].

Yaquicoccus Taylor, 1987: 34 [type species: Yaquicoccus bernadinus Taylor, 1987; original designation].

Remarks: Pyrgulopsis contains 143 currently recognized species; 126 are distributed in the western United States while the others are found in the Missouri River headwaters and in northern Mexico. Pyrgulopsis typically lives in springs and spring-fed streams, although a few species live in lakes and/or rivers. The systematics of Pyrgulopsis have been unstable in recent decades (see Hershler and Thompson 1987; Hershler 1994; Thompson and Hershler 2002; Liu and Hershler 2005), and genetic evidence suggests that the genus, as currently constituted, may be paraphyletic relative to Floridobia, which is distributed in Atlantic Coastal drainages (Hershler et al. 2003b; Liu and Hershler 2005). These taxa continue to be recognized as distinct (pending further phylogenetic study) because of their broad geographic separation and differences in their female reproductive anatomy (Liu and Hershler 2005).

\section{Pyrgulopsis aardahli Hershler, 1989}

Pyrgulopsis aardahli Hershler, 1989: 179-181, figs. 10-13. Spring at Bramlette Ranch, Benton Valley, Mono County, California. Holotype, USNM 860406; paratypes, USNM 857951.

Common name: Benton Valley springsnail.

Distribution: Known only from the type locality.

Taxonomy: Hershler (1994). 


\section{Pyrgulopsis aloba Hershler, 1998}

Pyrgulopsis aloba Hershler, 1998: 60-62, figs. 7F, 19D-E, 33A-B. Spring, northwest of Duckwater, Duckwater Valley, Nye County, Nevada. Holotype, USNM 883847; paratypes, USNM 860681.

Common name: Duckwater pyrg.

Distribution: Three springs in Duckwater Valley, Nevada.

\section{Pyrgulopsis amargosae Hershler, 1989}

Pyrgulopsis amargosae Hershler, 1989: 181-182, figs. 15-16, 17a, 18. Saratoga Spring, southern Death Valley, San Bernardino County, California. Holotype, USNM 860401; paratypes, USNM 853515.

Common name: Amargosa springsnail.

Distribution: Lower portion of Amargosa River drainage (Tecopa area, southern Death Valley), California.

Taxonomy: Hershler (1994).

Remarks: Genetic evidence suggests that $P$. amargosae is composed of at least two evolutionarily distinct lineages and requires taxonomic revision (Hershler and Liu 2008; Hershler et al. 2013).

\section{Pyrgulopsis anatina Hershler, 1998}

Pyrgulopsis anatina Hershler, 1998: 63-64, figs. 7H, 19H-I, 33F-H. Spring southeast of Old Collins Spring, Duckwater Valley, Nye County, Nevada. Holotype, USNM 883848; paratypes, USNM 860710.

Common name: Southern Duckwater pyrg.

Distribution: Known only from the type locality.

\section{Pyrgulopsis anguina Hershler, 1998}

Pyrgulopsis anguina Hershler, 1998: 110-111, figs. 9K, 23H-J, 44A-E. Big Springs, Snake Valley, White Pine County, Nevada. Holotype, USNM 874678; paratypes, USNM 860725.

Common name: Longitudinal gland pyrg.

Distribution: Snake Valley (Bonneville basin), Nevada-Utah. 
Pyrgulopsis archimedis Berry, 1947: 76-77, pl. 7, fig. 6. Upper Klamath Lake near Algoma, Klamath County, Oregon. Holotype, USNM 739417; paratypes, USNM 613965.

Common name: Archimedes pyrg.

Distribution: Upper Klamath Lake and the uppermost reach of its outflow (Link River), Oregon; Hat Creek and Fall River drainages, lower Pit River basin, California (Hershler 1994; Hershler et al. 2003a).

Taxonomy: Hershler (1994), Hershler et al. (2003a).

\section{Pyrgulopsis arizonae (Taylor, 1987)}

Apachecoccus arizonae Taylor, 1987: 32, fig. 15. Unnamed spring on north side of Gila River about $2 \mathrm{mi}[3.2 \mathrm{~km}]$ north of Bylas, Graham County, Arizona. Holotype, LACM 2203; paratypes, ANSP 376020, UF 160939, USNM 854090, UTEP 10050 .

Pyrgulopsis sancarlosensis Hershler in Hershler and Landye, 1988: 35, 39-40, figs. 13e, 26e, 31a-g, 32-33. Springs west of Tom Niece Springs, Graham

County, Arizona. Holotype, USNM 859051; paratypes, USNM 859052.

Common name: Apache springsnail.

Distribution: Springs along north side of Gila River between Bylas and Pima, southern Arizona.

Taxonomy: Hershler (1994).

\section{Pyrgulopsis augustae Hershler, 1998}

Pyrgulopsis augustae Hershler, 1998: 89, figs. 9B, 22A, 40A-B. Cain Spring, Antelope Valley, Lander County, Nevada. Holotype, USNM 874402; paratypes, USNM 860687.

Common name: Elongate Cain Spring pyrg.

Distribution: Known only from the type locality.

\section{Pyrgulopsis aurata Hershler, 1998}

Pyrgulopsis aurata Hershler, 1998: 74-75, figs. 8E, 20K-L, 36E-G. Coyote Spring, Pershing County, Nevada. Holotype, USNM 874393; paratypes, USNM 860696.

Common name: Pleasant Valley pyrg.

Distribution: Known only from the type locality. 


\section{Pyrgulopsis avernalis (Pilsbry, 1935)}

Fluminicola avernalis Pilsbry, 1935: 92-93, fig. 1. Colorado Desert [probably in error as there are no other reliable records for this species from the Colorado Desert; Hershler 1994]. Lectotype, ANSP 27784; paralectotypes, ANSP 375737 (mixed with Pyrgulopsis carinifera).

Common name: Moapa pebblesnail.

Distribution: Springs in Moapa Valley (lower Colorado River basin), Nevada (Hershler 1998).

Taxonomy: Hershler (1994).

\section{Pyrgulopsis bacchus Hershler in Hershler and Landye, 1988}

Pyrgulopsis bacchus Hershler in Hershler and Landye, 1988: 21, figs. 10d, 11 e-g, 12df, 14b, 15. Grapevine Spring, Mohave County, Arizona. Holotype, USNM 859037; paratypes, USNM 859038.

Common name: Grand Wash springsnail.

Distribution: Two closely proximal springs in Grand Wash, lower Colorado River basin, Arizona.

Taxonomy: Hershler (1994).

\section{Pyrgulopsis basiglans Hershler, 1998}

Pyrgulopsis basiglans Hershler, 1998: 91-93, figs. 9D, 13D, 22D, 40F-H. Spring, Cooks Creek, Carico Lake Basin, Lander County, Nevada. Holotype, USNM 874280; paratypes, USNM 860692.

Common name: Large gland Carico pyrg.

Distribution: Two springs in the Carico Lake basin, Nevada.

\section{Pyrgulopsis bernardina (Taylor, 1987)}

Yaquicoccus bernardinus Taylor, 1987: 34-35, fig. 16. Spring, 2,300 ft E, 4,600 ft S of NW corner, sec. 15, T24S, R30E, Cochise County, Arizona. Holotype, LACM 2186; paratypes, ANSP 376019, UF 160934, USNM 854078.

Pyrgulopsis cochisi Hershler in Hershler and Landye, 1988: 41, figs. 25d, 30h-k, 33-34. Spring at San Bernardino Ranch, Cochise County, Arizona. Holotype, 859055; paratypes, USNM 859056.

Common name: San Bernardino springsnail.

Distribution: Several springs in the upper San Bernardino basin, southern Arizona and northern Sonora (Mexico) (Varela-Romero et al. 2013).

Taxonomy: Hershler (1994). 
Pyrgulopsis bifurcata Hershler, 1998: 93-94, figs. 9E, 22E, 41A-C. Springs west of Carico Lake, Carico Lake Basin, Lander County, Nevada. Holotype, USNM 874306; paratypes, USNM 860693.

Common name: Small gland Carico pyrg.

Distribution: Known only from the type locality.

\section{Pyrgulopsis breviloba Hershler, 1998}

Pyrgulopsis breviloba Hershler, 1998: 39, 41, figs. 6G, 11C, 14D-F, 17L-M, 28D-F. Flag Springs (the middle of three), White River Valley, Nye County, Nevada. Holotype, USNM 873174; paratypes, USNM 860689.

Common name: Flag pyrg.

Distribution: Flag Springs complex (White River Valley), and one spring in Dry Lake Valley, Nevada.

\section{Pyrgulopsis bruesi Hershler and Sada, 2000}

Pyrgulopsis bruesi Hershler and Sada, 2000: 367-368, 370-372, figs. 1-4. Small stream that enters Fly Reservoir, about 23 airline-km north-northeast of Gerlach, Washoe County, Nevada. Holotype, USNM 892079; paratypes, USNM 860868.

Common name: Fly Ranch pyrg.

Distribution: Known only from the type locality.

\section{Pyrgulopsis bruneauensis Hershler, 1990}

Pyrgulopsis bruneauensis Hershler, 1990: 803, 805, 809, 811, 813-814, figs. 1-6. Spring along west side of Bruneau River, ca. $100 \mathrm{~m}$ downflow from Hot Creek's confluence with the river, Owyhee County, Idaho. Holotype, USNM 860507; paratypes, USNM 860508.

Common name: Bruneau Hot springsnail.

Distribution: Small springs along Hot Creek and confluent Bruneau River (Idaho). Taxonomy: Hershler (1994). 


\section{Pyrgulopsis bryantwalkeri Hershler, 1994}

Fluminicola nevadensis Walker, 1916: 6-7, unlabeled figure. Spring in the Cortez foot-hills, Humboldt Valley, Elko County, Nevada. Lectotype, UMMZ 118012; paralectotypes, ANSP 115948, MCZ 31450.

Pyrgulopsis bryantwalkeri Hershler, 1994: 23. Replacement name for Fluminicola nevadensis Walker, 1916; preoccupied in Pyrgulopsis by Pyrgula nevadensis Stearns, 1883.

Common name: Cortez Hills pebblesnail.

Distribution: Known from a single spring in the Humboldt River basin, Nevada (Hershler 1994).

Taxonomy: Hershler (1994).

\section{Pyrgulopsis californiensis (Gregg and Taylor, 1965)}

Fontelicella californiensis Gregg and Taylor, 1965: 109. Campo Creek, San Diego County, California, $0.6 \mathrm{mi}$. [1.0 km] east of Mountain Empire Dam. Holotype, UMMZ 220000.

Distribution: Southern California and adjacent Baja California. From the southern Sierra Nevada (western slope only) through the western Transverse Ranges and coastal plains to the Laguna Mountains.

Common name: Laguna Mountain springsnail.

Taxonomy: Hershler (1994).

Remarks: Genetic evidence suggests that $P$. californiensis is composed of two evolutionarily distinct lineages and requires taxonomic revision (Hershler and Liu 2010).

\section{Pyrgulopsis carinata Hershler, 1998}

Pyrgulopsis carinata Hershler, 1998: 60, figs. 7E, 19C, 32F-G. Little Warm Spring, Duckwater Valley, Nye County, Nevada. Holotype, USNM 883975; paratypes, USNM 860680.

Common name: Carinate Duckwater pyrg.

Distribution: Known only from the type locality. 
Fluminicola avernalis carinifera Pilsbry, 1935: 93, fig. 3. Colorado Desert [in error, probably Moapa Valley, Nevada; Hershler 1994]. Lectotype, ANSP 164091; paralectotypes, ANSP 375736.

Common name: Moapa Valley pyrg.

Distribution: Moapa Valley, lower Colorado River basin (Hershler 1998).

Taxonomy: Hershler (1994).

Remarks: Elevated to full species by Hershler (1994).

\section{Pyrgulopsis castaicensis Hershler and Liu, 2010}

Pyrgulopsis castaicensis Hershler and Liu, 2010: 6-10, figs. 3-5. Middle Canyon Spring, ca. $1.46 \mathrm{~km}$ southwest of Castaic Junction, Los Angeles County, California. Holotype, USNM 1120442; paratypes, USNM 1132532.

Common name: Middle Canyon Spring pyrg.

Distribution: Known only from the type locality in the Santa Clara River basin.

\section{Pyrgulopsis chamberlini Hershler, 1998}

Pyrgulopsis chamberlini Hershler, 1998: 122-124, figs. 10G, 25A-C, 47D-G. Spring, Glenwood, Sevier River drainage, Sevier County, Utah. Holotype, USNM 883576; paratypes, USNM 860729.

Common name: Smooth Glenwood pyrg.

Distribution: Two closely proximal springs in the Sevier River drainage (Utah).

\section{Pyrgulopsis cinerana Hershler, Frest, Liu, and Johannes, 2003}

Pyrgulopsis cinerana Hershler, Frest, Liu, and Johannes, 2003a: 296-299, figs. 4D, 18-19. Nearest spring east of Ash Valley Road (Modoc County 527) crossing of Ash Creek, north side of creek, JJJ Ranch, Lassen County, California. Holotype, USNM 1004543; paratypes, USNM 1004544.

Common name: Ash Valley pyrg.

Distribution: Cold springs associated with upper Ash Creek, upper Pit River basin. 


\section{Pyrgulopsis coloradensis Hershler, 1998}

Pyrgulopsis coloradensis Hershler, 1998: 29, figs. 6C, 17D, 27A-B. Blue Point Spring, Colorado River drainage, Clark County, Nevada. Holotype, USNM 854621; paratypes, USNM 860677.

Common name: Blue Point pyrg.

Distribution: Known only from the type locality.

\section{Pyrgulopsis conica Hershler in Hershler and Landye, 1988}

Pyrgulopsis conicus Hershler in Hershler and Landye, 1988: 21, figs. 10e, 16a-d, $17-$ 18. Dripping Springs, Mohave County, Arizona. Holotype, USNM 859039; paratypes, USNM 859040.

Common name: Kingman springsnail.

Distribution: Three springs in the Black Mountains, lower Colorado River basin, Arizona.

Taxonomy: Hershler (1994).

\section{Pyrgulopsis cruciglans Hershler, 1998}

Pyrgulopsis cruciglans Hershler, 1998: 72, figs. 8C, 20F-H, 36A-B. Flat Spring, Steptoe Valley, White Pine County, Nevada. Holotype, USNM 874285; paratypes, USNM 860709.

Common name: Transverse gland pyrg.

Distribution: Several springs in Steptoe Valley and adjacent basins, eastern Nevada.

\section{Pyrgulopsis crystalis Hershler and Sada, 1987}

Pyrgulopsis crystalis Hershler and Sada, 1987: 797, 799-802, figs. 8c,f,i, 18c, 23d, 24b, 28. Crystal Pool, Ash Meadows, Nye County, Nevada. Holotype, USNM 859205; paratypes, UF 93956, USNM 859206.

Common name: Crystal springsnail.

Distribution: Known only from the type locality.

Taxonomy: Hershler (1994). 
Pyrgulopsis cybele Hershler and Liu, 2012a: 23, 26-27, figs. 2-4. Unnamed spring brook on east side of South Fork Owyhee River, Elko County, Nevada. Holotype, USNM 1148155; paratypes, USNM 1157696.

Common name: Nature pyrg.

Distribution: Two closely proximal springs that discharge to the "Devil's Pinball" reach of the South Fork Owyhee River.

\section{Pyrgulopsis deaconi Hershler, 1998}

Pyrgulopsis deaconi Hershler, 1998: 23, 25, figs. 6B, 11A, 17B-C, 26D-G. Red Spring, Red Rock Canyon Recreation Lands [Red Rock Canyon National Conservation Area], Las Vegas Valley, Clark County, Nevada. Holotype, USNM 874454; paratypes, USNM 860676.

Common name: Spring Mountains pyrg.

Distribution: Spring Mountains (Las Vegas and Pahrump Valley drainages), Nevada.

\section{Pyrgulopsis deserta (Pilsbry, 1916)}

Amnicola deserta Pilsbry, 1916: 111. Washington County, Utah. Lectotype, ANSP 12112; paralectotypes, ANSP 396958.

Common name: Desert springsnail.

Distribution: Springs in the St. George area (Utah) and below the Virgin River narrows near Littlefield (Arizona), lower Colorado River basin (Hershler and Landye 1998).

Taxonomy: Hershler and Landye (1988), Hershler (1994).

\section{Pyrgulopsis diablensis Hershler, 1995}

Pyrgulopsis diablensis Hershler, 1995: 344-345, 347, 349, figs. 1-3, 5A. Unnamed creek, Del Puerto Canyon, Del Puerto [Canyon] Road, $20 \mathrm{~km}$ west of HW [Interstate] 5, Stanislaus County, California. Holotype, USNM 860645; paratypes, USNM 883791.

Common name: Diablo Range pyrg.

Distribution: Known only from the type locality. 


\section{Pyrgulopsis dixensis Hershler, 1998}

Pyrgulopsis dixensis Hershler, 1998: 73-74, figs. 8D, 13C, 20I-J, 36C-D. Springs westsouthwest of Hot Springs, Dixie Valley, Pershing County, Nevada. Holotype, USNM 874391; paratypes, USNM 860688.

Common name: Dixie Valley pyrg.

Distribution: Known only from the type locality.

\section{Pyrgulopsis eremica Hershler, 1995}

Pyrgulopsis eremica Hershler, 1995: 349-351, 354, figs. 5B, 7-9. Unnamed springs, tributary to Willow Creek, Willow Creek Valley, Lassen County, California. Holotype, USNM 860644; paratypes, USNM 858264.

Common name: Smoke Creek pyrg.

Distribution: Portions of the northeastern Great Basin in California.

\section{Pyrgulopsis erythropoma (Pilsbry, 1899)}

Fluminicola fusca var. minor Stearns, 1893: 282 [nomen nudum].

Fluminicola erythropoma Pilsbry, 1899: 125-126. Ash Meadows, Nye County, Nevada [Probably Kings Pool at Point of Rocks; Hershler and Sada 1987].

Lectotype, ANSP 73607; paralectotypes, ANSP 396951.

Common name: Ash Meadows pebblesnail.

Distribution: Point of Rocks spring complex, Ash Meadows.

Taxonomy: Hershler and Sada (1987), Hershler (1994).

Remarks: Stearn's (1893) publication of Fluminicola fusca var. minor was not accompanied by a description and therefore this name is not available per International Code of Zoological Nomenclature Article 12.1. His cited material for this nomen nudum (USNM 123624) was from the type locality of P. erythropoma (per Hershler 1994: 35) and closely conforms to this species in all respects.

\section{Pyrgulopsis fairbanksensis Hershler and Sada, 1987}

Pyrgulopsis fairbanksensis Hershler and Sada, 1987: 796-797, figs. 8d,g, 18a-b, 19a, 24d, 26-27. Fairbanks Spring, Ash Meadows, Nye County, Nevada. Holotype, USNM 859203; paratypes, UF 93955, USNM 859204.

Common name: Fairbanks springsnail.

Distribution: Known only from the type locality.

Taxonomy: Hershler (1994). 
Pyrgulopsis falciglans Hershler, Frest, Liu, and Johannes, 2003a: 293-296, figs. 4C, 15-16. Cold spring about $0.4 \mathrm{~km}$ southeast of Smokey Charlie [Charley] Spring and $0.32 \mathrm{~km}$ west of Modoc County 63, at source next to homestead cabin, Modoc County, California. Holotype, USNM 1004605; paratypes, USNM 1004606.

Common name: Likely pyrg.

Distribution: Two closely proximal springs along the South Fork Pit River.

\section{Pyrgulopsis fausta Hershler, 1998}

Pyrgulopsis fausta Hershler, 1998: 15, 23, figs. 6A, 12A, 17A, 26A-C. Corn Creek Springs, Las Vegas Valley, Clark County, Nevada. Holotype, USNM 874757; paratypes, USNM 860765.

Common name: Corn Creek pyrg.

Distribution: Known only from the type locality.

\section{Pyrgulopsis fresti Hershler and Liu, 2009}

Pyrgulopsis fresti Hershler and Liu, 2009: 9, 11-12, figs. 3-5. Tudor Warm Springs, east side of Owyhee River, second spring from north, Malheur County, Oregon. Holotype, USNM 1102148; paratypes, USNM 1116914.

Common name: Owyhee Hot springsnail.

Distribution: Springs along a short reach of Owyhee River drainage above Three Forks (Oregon).

\section{Pyrgulopsis fusca Hershler, 1998}

Pyrgulopsis fusca Hershler, 1998: 122, figs. 10F, 24K-M, 47A-C. Spring brook, Otter Creek, ca. $1.6 \mathrm{~km}$ above The Narrows, Piute County, Utah. Holotype, USNM 883439; paratypes, USNM 860728.

Common name: Otter Creek pyrg.

Distribution: Sevier River drainage, Utah.

\section{Pyrgulopsis gibba Hershler, 1995}

Pyrgulopsis gibba Hershler, 1995: 354, 357-358, figs. 5C, 10-12. Unnamed springs west of Fee Reservoir, Surprise Valley, Modoc County, California. Holotype, USNM 860643; paratypes, USNM 858275.

Distribution: Northwestern Great Basin (California, Nevada, Oregon) (Hershler 1998). 


\section{Pyrgulopsis gilae (Taylor, 1987)}

Fontelicella gilae Taylor, 1987: 16, fig. 7. Springs on north side of East Fork of Gila River, Grant County, New Mexico. Holotype LACM 2214; paratypes, ANSP 376025, UF 160936, USNM 854087, UTEP 10054.

Common name: Surprise Valley pyrg.

Distribution: Several groups of springs in lower reach of the East Fork Gila River basin (below the mouth of Black Canyon), and a single spring along the Gila River ca. $2 \mathrm{~km}$ below the East Fork confluence (New Mexico) (Hershler et al. 2014b).

Taxonomy: Hershler (1994), Hershler et al. (2014b).

\section{Pyrgulopsis giulianii Hershler and Pratt, 1990}

Pyrgulopsis giulianii Hershler and Pratt, 1990: 279-281, 283-285, figs. 1-3. Sand Canyon, Kern County, California. Holotype, USNM 860444; paratypes, SBMNH 35140, USNM 853519.

Common name: Southern Sierra Nevada springsnail.

Distribution: Springs along the flanks of the southern Sierra Nevada, California. Taxonomy: Hershler (1994).

\section{Pyrgulopsis glandulosa Hershler in Hershler and Landye, 1988}

Pyrgulopsis glandulosa Hershler in Hershler and Landye, 1988: 8, 11, 15, 17,

figs. 3a-c, 4-9, 10a-b. Nelson Place Spring, Yavapai County, Arizona. Holotype, USNM 859047; paratypes, USNM 859048.

Common name: Verde Rim springsnail.

Distribution: Headwaters (two closely proximal springs) of Sycamore Creek, Verde River drainage, central Arizona.

Taxonomy: Hershler (1994).

\section{Pyrgulopsis gracilis Hershler, 1998}

Pyrgulopsis gracilis Hershler, 1998: 43, 45, 47, figs. 6I, 11D, 18B-C, 29F-H. Emigrant Springs (northernmost in spring complex), White River Valley, Nye County, Nevada. Holotype, USNM 873158; paratypes, USNM 860698.

Common name: Emigrant pyrg.

Distribution: Emigrant Springs complex, White River Valley, Nevada. 
Pyrgulopsis greggi Hershler, 1995: 358-359, figs. 5D, 14-16. Grapevine Creek, Fort Tejon State Historical Park, Kern County, California. Holotype, USNM 860641; paratypes, USNM 874319.

Common name: Kern River springsnail.

Distribution: Grapevine Creek drainage, upper Kern River basin (California).

\section{Pyrgulopsis hamlinensis Hershler, 1998}

Pyrgulopsis hamlinensis Hershler, 1998: 106-108, figs. 9I, 22K, 43A-C. Springs

$0.5 \mathrm{~km}$ east of White Rock Cabin Springs, Hamlin Valley, Beaver County, Utah. Holotype, USNM 883215; paratypes, USNM 860695.

Common name: Hamlin Valley pyrg.

Distribution: Known only from the type locality.

\section{Pyrgulopsis hovinghi Hershler, 1998}

Pyrgulopsis hovinghi Hershler, 1998: 115, 117, figs. 10B, 11I, 16D-F, 24E, 45G-I. Prather Springs, Thousand Springs Valley, Elko County, Nevada. Holotype, USNM 874075; paratypes, USNM 860720.

Common name: Upper Thousand Spring pyrg.

Distribution: Known only from the type locality.

\section{Pyrgulopsis hualapaiensis Hershler, Liu, and Stevens, 2016}

Pyrgulopsis hualapaiensis Hershler, Liu, and Stevens, 2016b: 74-79, figs. 2-4. Upper Peach Springs, outflow just below concrete weir, Hualapai Indian Reservation, Mohave County, Arizona. Holotype, USNM 1248611; paratypes, USNM 1266144.

Common name: Hualapai pyrg [name newly introduced herein].

Distribution: Found only at upper Peach Springs (consisting of two closely proximal spring complexes), lower Colorado River basin, Arizona.

\section{Pyrgulopsis hubbsi Hershler, 1998}

Pyrgulopsis hubbsi Hershler, 1998: 33, 35-36, figs. 6E, 14A-C, 17F-G, 27F-H. Hiko Spring, Pahranagat Valley, Lincoln County, Nevada.

Common name: Hubbs pyrg.

Distribution: Pahranagat Valley, White River drainage, Nevada. 


\section{Pyrgulopsis humboldtensis Hershler, 1998}

Pyrgulopsis humboldtensis Hershler, 1998: 97, figs. 9H, 13E, 22H-J, 42F-I. Springs, East Fork Beaver Creek (above Cabin Creek confluence), North Fork Humboldt River, Elko County, Nevada. Holotype, USNM 874722; paratypes, USNM 860718 .

Common name: Humboldt pyrg.

Distribution: Humboldt River drainage, northern Nevada.

\section{Pyrgulopsis imperialis Hershler, 1998}

Pyrgulopsis imperialis Hershler, 1998: 86-87, figs. 8L, 21J-K, 39D-F. Spring, south side of road, Thacker Pass, Kings River Valley, Humboldt County, Nevada. Holotype, USNM 874207; paratypes, USNM 860716.

Common name: Kings River pyrg.

Distribution: Two closely proximal springs in Kings River Valley, Nevada.

\section{Pyrgulopsis inopinata Hershler, 1998}

Pyrgulopsis inopinata Hershler, 1998: 124-125, figs. 10H, 25D-F, 47H-J. Spring, Glenwood, Sevier River drainage, Sevier County, Utah. Holotype, USNM 883493; paratypes, USNM 860730.

Common name: Carinate Glenwood pyrg.

Distribution: Three springs in the Sevier River drainage, Utah.

\section{Pyrgulopsis intermedia (Tryon, 1865)}

Pomatiopsis intermedia Tryon, 1865: 220, pl. 22: fig. 8. Crooked Creek, Owyhee, southeastern Oregon. Lectotype, ANSP 27958; paralectotypes, ANSP 396959.

Common name: Crooked Creek springsnail.

Distribution: Great Basin (Barren Valley) and Owyhee River basin, Oregon (Hershler and Liu, 2009).

Taxonomy: Hershler (1994), Hershler and Liu (2009).

\section{Pyrgulopsis isolata Hershler and Sada, 1987}

Pyrgulopsis isolata Hershler and Sada, 1987: 807-810, figs. 19d, 29c,f, 33d,g, 37-38. Spring south of Clay Pits, Ash Meadows, Nye County, Nevada. Holotype, USNM 859201; paratypes, UF 93959; USNM 859202.

Common name: Elongate-gland springsnail.

Distribution: Known only from the type locality.

Taxonomy: Hershler (1994). 
Fontelicella kolobensis Taylor, 1987: 19, fig. 8. Toquerville Springs, Washington County, Utah. Holotype, LACM 2216.

Fontelicella pinetorum Taylor, 1987: 20, fig. 9. Spring tributary to Leeds Creek, Washington County, Utah. Holotype, LACM 2217.

Common name: Toquerville springsnail.

Distribution: Eastern Great Basin and lower Colorado River drainage (Idaho, Nevada, Utah) (Hershler 1998).

Taxonomy: Hershler (1994).

\section{Pyrgulopsis landyei Hershler, 1998}

Pyrgulopsis landyei Hershler, 1998: 70-71, figs. 8A, 20B, 35C-F. Spring ca. 1.6 km north-northwest of Steptoe Ranch, Steptoe Valley, White Pine County, Nevada. Holotype, USNM 892014; paratypes, USNM 860685.

Common name: Landyes pyrg.

Distribution: Known only from the type locality.

\section{Pyrgulopsis lasseni Hershler, Frest, Liu, and Johannes, 2003}

Pyrgulopsis lasseni Hershler, Frest, Liu, and Johannes, 2003a: 299, 301-302, figs. 4E, 20-21. Willow Creek on both sides of wooden foot bridge at a picnic area just downstream (west) of Willow Creek Campground, north side of CA 139, about $0.16 \mathrm{rd}$. km west of Hayden Hill Cut Off [Cutoff] Road junction, Modoc National Forest, Lassen County, California. Holotype, USNM 1004532; paratypes, USNM 1004533.

Common name: Willow Creek pyrg.

Distribution: Upper reach of Willow Creek and an associated thermal spring complex, upper Pit River basin (California).

\section{Pyrgulopsis lata Hershler, 1998}

Pyrgulopsis lata Hershler, 1998: 41, 43, figs. 6H, 12D, 18A, 29A-E. Butterfield Springs, White River Valley, Nye County, Nevada. Holotype, USNM 874667; paratypes, USNM 860697.

Common name: Butterfield pyrg.

Distribution: Known only from the type locality. 


\section{Pyrgulopsis lentiglans Hershler, 1998}

Pyrgulopsis lentiglans Hershler, 1998: 118-120, figs. 10D, 24G-H, 46C-E. Crittenden Springs, Thousand Springs Creek, Elko County, Nevada. Holotype, USNM 874724; paratypes, USNM 860722.

Common name: Crittenden pyrg.

Distribution: Two springs in the Thousand Springs drainage, northeastern Nevada.

\section{Pyrgulopsis leporina Hershler, 1998}

Pyrgulopsis leporina Hershler, 1998: 96-97, figs. 9G, 22G, 42A-E. Springs, Rabbit Creek, Humboldt River drainage, Elko County, Nevada. Holotype, USNM 874336; paratypes, USNM 860717.

Common name: Elko pyrg.

Distribution: Single springs in both the Humboldt River drainage and Ruby Valley, Nevada.

\section{Pyrgulopsis licina Hershler, Liu, and Bradford, 2013}

Pyrgulopsis licina Hershler, Liu, and Bradford, 2013: 32-34, 36, figs. 3, 4A-B. Spring south of Clay Pits, Ash Meadows, Nye County, Nevada. Holotype, USNM 850347; paratypes, USNM 1204732.

Common name: Curved filament pyrg [name newly introduced herein.]

Distribution: Ash Meadows, Amargosa River basin (Nevada).

\section{Pyrgulopsis limaria Hershler, 1998}

Pyrgulopsis limaria Hershler, 1998: 82-83, figs. 8I, 21E-F, 38A-E. Spring brook, Mud Meadow drainage, Humboldt County, Nevada. Holotype, USNM 873232; paratypes, USNM 860706.

Common name: Squat Mud Meadows pyrg.

Distribution: Mud Meadow drainage, northwestern Nevada.

\section{Pyrgulopsis lindae Hershler, Liu, Babbitt, Kellogg, and Howard, 2016}

Pyrgulopsis lindae Hershler, Liu, Babbitt, Kellogg, and Howard, 2016a: 7, 9-10, figs. 3A, 4. San Domingo Creek, $3.8 \mathrm{~km}$ up flow [upflow] from Dogtown along San Domingo Road, Calaveras County, California. Holotype, USNM 905258; paratypes, USNM 1254709.

Common name: San Domingo pyrg.

Distribution: Three localities in the upper Calaveras and upper Tuolumne River basins, western California. 
Pyrgulopsis lockensis Hershler, 1998: 57-59, figs. 7C, 12F, 14G-I, 19A, 32A-C. Spring at Lockes, Duckwater Valley, Nye County, Nevada. Holotype, USNM 874779; paratypes, USNM 860679.

Common name: Lockes pyrg.

Distribution: Known only from the type locality.

\section{Pyrgulopsis longae Hershler, 1995}

Pyrgulopsis longae Hershler, 1995: 359, 362, figs. 5E, 17-19. Unnamed spring about $4.8 \mathrm{~km}$ west-southwest of Hallelujah Junction, Long Valley, Lassen County. Holotype, USNM 860642; paratypes, USNM 858262.

Common name: Long Valley pyrg.

Distribution: Known only from the type locality.

\section{Pyrgulopsis longiglans Hershler, 1998}

Pyrgulopsis longiglans Hershler, 1998: 77-79, figs. 8F, 20M-P, 37A-C. Spring northnorthwest of Holbrook Junction, Antelope Valley, Douglas County, Nevada. Holotype, USNM 873409; paratypes, USNM 860701.

Common name: Western Lahontan pyrg.

Distribution: Several basins in northwestern Nevada.

\section{Pyrgulopsis longinqua (Gould, 1855)}

Amnicola longinqua Gould, 1855: 130. Colorado Desert (Cienega Grande). Types not located [USNM 12112 may be syntypes of this species; Hershler 1994].

Common name: Salton Sea springsnail.

Distribution: A single spring in the Salton Sea basin, eastern California (Hershler 1994).

Taxonomy: Hershler (1994).

\section{Pyrgulopsis marcida Hershler, 1998}

Pyrgulopsis marcida Hershler, 1998: 47-50, figs. 6J, 18D-F, 30A-C. Hardy Springs, White River Valley, Nye County, Nevada. Holotype, USNM 873154; paratypes, USNM 860711.

Common name: Hardy pyrg.

Distribution: Several springs in White River Valley and one spring in Cave Valley (Nevada). 
Pyrgulopsis marilynae Hershler, Ratcliffe, Liu, Lang, and Hay, 2014

Pyrgulopsis marilynae Hershler, Ratcliffe, Liu, Lang, and Hay, 2014b: 76-78, figs. 3, 4A-B. Spring $0.48 \mathrm{~km}$ north, $0.48 \mathrm{~km}$ west of Jordan Canyon, Catron County,

New Mexico. Holotype, USNM 1135068; paratypes, USNM 1232474.

Common name: Jordan Hot springsnail [name newly introduced herein].

Distribution: Short reach of the Middle Fork Gila River drainage just below Jordan Hot Springs (New Mexico).

\section{Pyrgulopsis merriami (Pilsbry and Beecher in Pilsbry, 1892)}

Fluminicola merriami Pilsbry and Beecher in Pilsbry, 1892: 143. A warm spring in Pahranagat Valley, Nevada. Lectotype, ANSP 67278; paralectotypes, ANSP 27782, USNM 123626.

Common name: Pahranagat pebblesnail.

Distribution: White River and Pahranagat Valleys, southern Nevada (Hershler 1998). Taxonomy: Hershler (1994).

\section{Pyrgulopsis micrococcus (Pilsbry in Stearns, 1893)}

Amnicola micrococcus Pilsbry in Stearns, 1893: 277, fig. 1. Small spring in Oasis Valley, Nevada. Lectotype, ANSP 67279; paralectotypes, ANSP 368399, USNM 123622.

Common name: Oasis Valley springsnail.

Distribution: Oasis Valley, upper Amargosa River basin (Nevada) (Hershler et al. 2013).

Taxonomy: Hershler and Sada (1987), Hershler $(1989,1994)$, Hershler et al. (2013).

\section{Pyrgulopsis militaris Hershler, 1998}

Pyrgulopsis militaris Hershler, 1998: 79-80, figs. 8G, 15G-I, 21A-B, 37D-F. Spring west of Soldier Meadow Ranch, Humboldt County, Nevada. Holotype, USNM 873203; paratypes, USNM 860704.

Common name: Northern Soldier Meadow pyrg.

Distribution: One site each in Soldier Meadow and Craine Creek drainage, northwestern Nevada. 
Pyrgulopsis millenaria Hershler, 1998: 117-118, figs. 10C, 24F, 46A-B. Springs below Twentyone Mile Dam, Thousand Springs Creek, Elko County, Nevada. Holotype, USNM 874720; paratypes, USNM 860721.

Common name: Twentyone Mile pyrg.

Distribution: Known only from the type locality.

\section{Pyrgulopsis milleri Hershler and Liu, 2010}

Pyrgulopsis milleri Hershler and Liu, 2010: 10, 12-15, figs. 6-8. Creek $1.13 \mathrm{~km}$ east of Pierpoint Spring along California Highway 190, ca. $25.1 \mathrm{~km}$ east of Springville, Tulare County, California. Holotype, SBMNH 83651; paratypes, SBMNH 74688, USNM 1132568.

Common name: Pierpoint Spring pyrg.

Distribution: Several springs along a short reach of the South Fork of the Middle Fork Tule River.

\section{Pyrgulopsis montana Hershler, 1998}

Pyrgulopsis montana Hershler, 1998: 31, 33, figs. 6D, 11B, 12B, 17E, 27C-E. Spring, upper Camp Valley, Lincoln County, Nevada. Holotype, USNM 874786; paratypes, USNM 860694.

Common name: Camp Valley pyrg.

Distribution: Known only from the type locality.

Pyrgulopsis montezumensis Hershler in Hershler and Landye, 1988

Pyrgulopsis montezumensis Hershler in Hershler and Landye, 1988: 23, 28, 30, figs. 10g, 13a,d, 21a-c, 22-23. Montezuma Well, Yavapai County, Arizona. Holotype, USNM 859043; paratypes, USNM 859044.

Common name: Montezuma Well springsnail.

Distribution: Known only from the type locality and its upper $110 \mathrm{~m}$ of outflow, Verde River drainage (lower Colorado River basin).

Taxonomy: Hershler (1994). 


\section{Pyrgulopsis morrisoni Hershler in Hershler and Landye, 1988}

Pyrgulopsis morrisoni Hershler in Hershler and Landye, 1988: 21, 23, figs. 10f, 16e-h, 19-20. Page Springs, Yavapai County, Arizona. Holotype, USNM 859041; paratypes, USNM 859042.

Common name: Page springsnail.

Distribution: Verde Valley, lower Colorado River basin, Arizona.

Taxonomy: Hershler (1994).

\section{Pyrgulopsis nanus Hershler and Sada, 1987}

Pyrgulopsis nanus Hershler and Sada, 1987: 802-804, figs. 29a,d, 30-32, 33a,b. Five Springs, Ash Meadows, Nye County, Nevada. Holotype, USNM 859191; paratypes, UF 93957, USNM 859192.

Common name: Distal-gland springsnail.

Distribution: Four spring brooks in Ash Meadows.

Taxonomy: Hershler (1994).

\section{Pyrgulopsis neritella Hershler, 1998}

Pyrgulopsis neritella Hershler, 1998: 68-70, figs. 7L, 11G, 20A, 35A-B. Springs north of Steptoe Ranch, Steptoe Valley, White Pine County, Nevada. Holotype, USNM 883932; paratypes, USNM 860684.

Common name: Neritiform Steptoe Ranch pyrg.

Distribution: Two closely proximal springs in Steptoe Valley.

\section{Pyrgulopsis nevadensis (Stearns, 1883)}

Pyrgula nevadensis Stearns, 1883: 173, unlabeled figure (p. 173). Pyramid Lake, Washoe County, Nevada. Lectotype, ANSP 27811; paralectotypes, ANSP 375739.

Common name: Corded pyrg.

Distribution: Three lakes in the western Great Basin; has not been collected in many years and may now be extinct.

Taxonomy: Hershler and Thompson (1987), Hershler (1994). 
Pyrgulopsis nonaria Hershler, 1998: 125, 127, figs. 10I, 25G, 48A-C. Spring along east side of Ninemile Reservoir, San Pete [Sanpete] County, Utah. Holotype, USNM 883566; paratypes, USNM 860731.

Common name: Ninemile pyrg.

Distribution: Two closely proximal springs in the San Pitch River drainage, Utah.

\section{Pyrgulopsis notidicola Hershler, 1998}

Pyrgulopsis notidicola Hershler, 1998: 83-84, figs. 8J, 21 G-H, 38F-H. Spring, Mud Meadow drainage, Humboldt County, Nevada. Holotype, USNM 873215; paratypes, USNM 860707.

Common name: Elongate Mud Meadows pyrg.

Distribution: Mud Meadow drainage, northwestern Nevada.

Pyrgulopsis ojaiensis Hershler, Liu, Babbitt, Kellogg, and Howard, 2016

Pyrgulopsis ojaiensis Hershler, Liu, Babbitt, Kellogg, and Howard, 2016b: 10-12, figs. 3B, 5. Sisar Creek, $3.4 \mathrm{~km}$ up flow [upflow] from Sulphur Springs, Ventura County, California. Holotype, SBMNH 74347; paratypes, SBMNH 46096.

Common name: Sisar pyrg.

Distribution: Known only from the type locality.

\section{Pyrgulopsis orbiculata Hershler, 1998}

Pyrgulopsis orbiculata Hershler, 1998: 67-68, figs. 7K, 19L, 34F-G. Spring at Steptoe Ranch, Steptoe Valley, White Pine County, Nevada. Holotype, USNM 873196; paratypes, 860682 .

Common name: Sub-globose Steptoe Ranch pyrg.

Distribution: Several springs in Steptoe Valley.

\section{Pyrgulopsis owensensis Hershler, 1989}

Pyrgulopsis owensensis Hershler, 1989: 187-189, figs. 26a-d, 27-31. Unnamed spring in canyon south of Piute Creek, Owens Valley, Mono County, California. Holotype, USNM 860404; paratypes, USNM 857955.

Common name: Owens Valley springsnail.

Distribution: Springs in northeastern Owens Valley; also found in one spring along the East Fork Walker River (Hershler and Pratt 1990).

Taxonomy: Hershler (1994). 


\section{Pyrgulopsis owyheensis Hershler and Liu, 2009}

Pyrgulopsis owyheensis Hershler and Liu, 2009: 13-14, 16-19, figs. 6-9. Owyhee Spring, Malheur County, Oregon. Holotype, USNM 883435; paratypes, USNM 1116915.

Common name: Owyhee upland pyrg.

Distribution: Owyhee and Malheur River basins (Oregon).

\section{Pyrgulopsis papillata Hershler, 1998}

Pyrgulopsis papillata Hershler, 1998: 59-60, figs. 7D, 11E, 19B, 32D-E. Big Warm Spring, Duckwater Valley, Nye County, Nevada. Holotype, USNM 873185; paratypes, USNM 860678.

Common name: Big Warm Spring pyrg.

Distribution: Two springs in Duckwater Valley, Nevada.

\section{Pyrgulopsis peculiaris Hershler, 1998}

Pyrgulopsis peculiaris Hershler, 1998: 108-110, figs. 9J, 23A-G, 43D-I. Spring, Maple Grove, Round Valley, Millard County, Utah. Holotype, USNM 883933; paratypes, USNM 860703.

Common name: Bifid duct pyrg.

Distribution: East-central portion of the Bonneville basin (Nevada, Utah).

\section{Pyrgulopsis pellita Hershler, 1998}

Pyrgulopsis pellita Hershler, 1998: 94-96, figs. 9F, 22F, 41D-F. Sullivan Spring, Antelope Valley, Eureka County, Nevada. Holotype, USNM 883850; paratypes, USNM 860715.

Common name: Antelope Valley pyrg.

Distribution: Known only from the type locality.

\section{Pyrgulopsis perforata Hershler, Liu, and Bradford, 2013}

Pyrgulopsis perforata Hershler, Liu, and Bradford, 2013: 36-37, 39. Easternmost spring from Scotty's [Scottys] Castle along California Highway 72, Grapevine Canyon, Death Valley, Inyo County, California. Holotype, USNM 853507; paratypes, USNM 1204734.

Common name: Scottys Castle pyrg [name newly introduced herein].

Distribution: Lower portion of Grapevine Canyon and Grapevine Mountains (lower Amargosa River basin, California). 
Pyrgulopsis perturbata Hershler, 1989: 189-190, 192, 194, figs. 26e-g, 33-35. Southern of two "Northwest Springs," Fish Slough, Mono County, California. Holotype, USNM 860407; paratypes, USNM 853546.

Common name: Fish Slough springsnail.

Distribution: Fish Slough, Owens River drainage.

Taxonomy: Hershler (1994).

\section{Pyrgulopsis pictilis Hershler, 1998}

Pyrgulopsis pictilis Hershler, 1998:89-91, figs. 9C, 22B-C, 40C-E. Cain Spring, Antelope Valley, Lander County, Nevada. Holotype, USNM 874401; paratypes, USNM 860713.

Common name: Ovate Cain Spring pyrg.

Distribution: Known only from the type locality.

\section{Pyrgulopsis pilsbryana (Baily and Baily, 1952)}

Amnicola pilsbryi Baily and Baily, 1951: 50, pl. 4: fig. 3. Lifton, Ideal Beach, Bear Lake, Idaho. Holotype, ANSP 187691; paratypes, ANSP 368401.

Amnicola pilsbryana Baily and Baily, 1952: 144. Replacement name for Amnicola pilsbryi Baily and Baily, 1951; preoccupied in Amnicola by Amnicola pilsbryi Walker, 1906.

Common name: Bear Lake springsnail.

Distribution: Bear River basin (Idaho, Utah) (Hershler 1998).

Taxonomy: Hershler (1994).

\section{Pyrgulopsis pisteri Hershler and Sada, 1987}

Pyrgulopsis pisteri Hershler and Sada, 1987: 804-807, figs. 29b,e, 33c, 34a-e, 35-36.

Marsh Spring, Ash Meadows, Nye County, Nevada. Holotype, USNM 859197; paratypes, UF 94958, USNM 859198.

Common name: Median-gland springsnail.

Distribution: Three sites in Ash Meadows.

Taxonomy: Hershler (1994). 


\section{Pyrgulopsis planulata Hershler, 1998}

Pyrgulopsis planulata Hershler, 1998: 64-66, figs. 7I, 13B, 15A-C, 19J, 34A-C.

Spring northwest of Clark Spring, Steptoe Valley, White Pine County, Nevada.

Holotype, USNM 892023; paratypes, USNM 860686.

Common name: Flat-topped Steptoe pyrg.

Distribution: Known only from the type locality.

\section{Pyrgulopsis plicata Hershler, 1998}

Pyrgulopsis plicata Hershler, 1998: 120-121, figs. 10E, 13F, 24I-J, 46F-G. Spring, Black Canyon, East Fork Sevier River, Garfield County, Utah. Holotype, USNM 883594; paratypes, USNM 860727.

Common name: Black Canyon pyrg.

Distribution: Known only from the type locality.

\section{Pyrgulopsis robusta (Walker, 1908)}

Pomatiopsis robusta Walker, 1908: 97, unlabeled figure. Jackson Lake, Wyoming. Types have not been located.

Amnicola hendersoni Pilsbry, 1933: 10, pl. 2: figs. 2, 9 10. South of Burns, Oregon. Holotype, ANSP 145951; paratypes, ANSP 396668.

Amnicola idahoensis Pilsbry, 1933: 11, pl. 2, figs. 3-5. [Snake River] at Homedale, Owyhee County, Idaho. Lectotype, ANSP 152677; paralectotype, ANSP 396960.

Common name: Jackson Lake springsnail.

Distribution: Portions of the Snake-Columbia River basin and Oregon Great Basin (Hershler and Liu 2004a; Lysne et al. 2007).

Taxonomy: Hershler (1994), Hershler and Liu (2004a).

Remarks: Microsatellite evidence suggests that $P$. robusta may be a polyploid (Liu and Hershler 2014).

\section{Pyrgulopsis ruinosa Hershler, 1998}

Pyrgulopsis ruinosa Hershler, 1998: 54-56, figs. 7A, 18M, 31A-C. Spring southwest of The Crossing, Fish Lake Valley, Esmeralda County, Nevada. Holotype, USNM 874307; paratypes, USNM 860700.

Common name: Fish Lake Valley pyrg.

Distribution: Known only from the type locality and may now be extinct (Hershler 1998). 
Pyrgulopsis rupinicola Hershler, Frest, Liu, and Johannes, 2003a: 288-292, figs. 4B, 11-12. Sucker Springs Creek east of California Fish and Game [California Fish and Wildlife] Pit River Hatchery on northwest side of access road above intake for the hatchery, northwest of Pit River, over $1.6 \mathrm{~km}$ southwest of Pit 1 Powerhouse (Pacific Gas and Electric), Shasta County, California. Holotype, USNM 892187; paratypes, USNM 1004526, USNM 1004527.

Common name: Sucker Springs pyrg.

Distribution: Known only from the type locality.

\section{Pyrgulopsis sadai Hershler, 1998}

Pyrgulopsis sadai Hershler, 1998: 87-89, figs. 9A, 21L-N, 39G-J. Spring, Moss Creek, Reese River Valley, Lander County, Nevada. Holotype, USNM 874397; paratypes, USNM 860702.

Common name: Sadas pyrg.

Distribution: Lahontan basin and Owyhee River drainage, north-central Nevada.

\section{Pyrgulopsis sanchezi Hershler, Liu, and Bradford, 2013}

Pyrgulopsis sanchezi Hershler, Liu, and Bradford, 2013: 39-42, figs. 4E-F, 7. Purgatory Spring, Ash Meadows, Nye County, Nevada. Holotype, USNM 850333; paratypes, USNM 1204735.

Common name: Sanchez pyrg [name newly introduced herein].

Distribution: Five groundwater discharge areas in the Amargosa River basin (California, Nevada).

\section{Pyrgulopsis sathos Hershler, 1998}

Pyrgulopsis sathos Hershler, 1998: 37, 39, figs. 6F, 12C, 17H-K, 28A-C. Flag Springs, White River Valley, Nye County, Nevada. Holotype, USNM 874664; paratypes, USNM 860691.

Common name: White River Valley pyrg.

Distribution: White River Valley, Colorado River basin, Nevada. 


\section{Pyrgulopsis saxatilis Hershler, 1998}

Pyrgulopsis saxatilis Hershler, 1998: 111, 113, figs. 9L, 11H, 16A-C, 23K-L, 44F-H. Warm Springs, Snake Valley, Millard County, Utah. Holotype, USNM 883237; paratypes, USNM 860726.

Common name: Sub-globose Snake pyrg.

Distribution: Known only from the type locality.

\section{Pyrgulopsis serrata Hershler, 1998}

Pyrgulopsis serrata Hershler, 1998: 71-72, figs. 8B, 15D-F, 20C-E, 35G-J. Indian Ranch Spring, Steptoe Valley, White Pine County, Nevada. Holotype, USNM 874314; paratypes, USNM 860719.

Common name: Northern Steptoe pyrg.

Distribution: Several springs in Steptoe Valley.

Pyrgulopsis similis Hershler, Ratcliffe, Liu, Lang, and Hay, 2014

Pyrgulopsis similis Hershler, Ratcliffe, Liu, Lang, and Hay, 2014b: 78-81, figs. 4C-D, 5. Spring along Beaver Creek, ca. $0.29 \mathrm{~km}$ north and $0.4 \mathrm{~km}$ west of confluence with Taylor Creek, Catron County, New Mexico. Holotype, USNM 1135064; paratypes, USNM 1135065.

Common name: Catron pyrg [name newly introduced herein].

Distribution: Short reach of the East Fork Gila River drainage from just above Wall

Lake to slightly above the mouth of Burnt Corral Canyon (New Mexico).

\section{Pyrgulopsis simplex Hershler in Hershler and Landye, 1988}

Pyrgulopsis simplex Hershler in Hershler and Landye, 1988: 32, figs. 21g-j, 26b, 27-28. Spring near Strawberry, Gila County, Arizona. Holotype, USNM 859049; paratypes, USNM 859050.

Common name: Fossil springsnail.

Distribution: Fossil Creek drainage, Verde River drainage, Arizona.

Taxonomy: Hershler (1994). 
Pyrgulopsis solus Hershler in Hershler and Landye, 1988: 30, 32, figs. 21d-f, 24, 25, 26a. Brown Spring, in southern end of Verde Valley, Yavapai County, Arizona. Holotype, 859045; paratypes, USNM 859046.

Common name: Brown springsnail.

Distribution: Known only from the type locality in the lower Colorado River basin. Taxonomy: Hershler (1994).

\section{Pyrgulopsis stearnsiana (Pilsbry, 1899)}

Pyrgulopsis stearnsiana Pilsbry, 1899: 124-125. Near Oakland (California).

Lectotype, ANSP 27961; paralectotypes, ANSP 396667.

Distribution: Central California coastal drainages (Hershler et al. 2016a).

Common name: Yaqui springsnail.

Taxonomy: Hershler (1994).

Remarks: Genetic evidence suggests that $P$. stearnsiana is paraphyletic relative to $P$. diablensis and $P$. giulianii, and may require taxonomic revision (Hershler et al. 2016a).

\section{Pyrgulopsis sterilis Hershler, 1998}

Pyrgulopsis sterilis Hershler, 1998: 53-54, figs. 6L, 18K-L, 30G-I. Spring, Hunts Canyon Ranch, Ralston Valley, Nye County, Nevada. Holotype, USNM 874876; paratypes, USNM 860714.

Common name: Sterile basin pyrg.

Distribution: Three springs in Ralston and Stone Cabin Valleys, southwestern Nevada.

\section{Pyrgulopsis sublata Hershler, 1998}

Pyrgulopsis sublata Hershler, 1998: 56-57, figs. 7B, 12E, 18N-O, 31D-F. Wambolt Springs, Lake Valley, Lincoln County, Nevada. Holotype, USNM 874681; paratypes, USNM 860724.

Common name: Lake Valley pyrg.

Distribution: Known only from the type locality. 


\section{Pyrgulopsis sulcata Hershler, 1998}

Pyrgulopsis sulcata Hershler, 1998: 66-67, figs. 7J, 11F, 19K, 34D-E. Springs north of Grass Springs, Steptoe Valley, White Pine County, Nevada. Holotype, USNM 874326; paratypes, USNM 860683.

Common name: Southern Steptoe pyrg.

Distribution: Two springs in Steptoe Valley, Nevada.

\section{Pyrgulopsis taylori Hershler, 1995}

Pyrgulopsis taylori Hershler, 1995: 362-363, 365, 367, figs. 5F, 20-22. Unnamed spring tributary to San Luis Obispo Creek, $4.8 \mathrm{~km}$ north of San Luis Obispo, east of HW 101, San Luis Obispo County, California. Holotype, USNM 860646; paratypes, USNM 883792.

Common name: San Luis Obispo pyrg.

Distribution: San Luis Obispo Creek drainage (California).

\section{Pyrgulopsis thermalis (Taylor, 1987)}

Fontelicella thermalis Taylor, 1987: 28, fig. 13. Hot spring on east side of Gila River, NE1/4 SW1/4 sec. 17 T13S R13W, Grant County, New Mexico. Holotype, LACM 2224; paratypes, ANSP 376026, UF 160941, USNM 954086, UTEP 10058.

Common name: New Mexico hot springsnail.

Distribution: Thermal springs along the East Fork Gila River, New Mexico.

Taxonomy: Hershler (1994).

\section{Pyrgulopsis thompsoni Hershler in Hershler and Landye, 1988}

Pyrgulopsis thompsoni Hershler in Hershler and Landye, 1988: 41-42, figs. 26f, 36 38. Peterson Ranch Springs, Santa Cruz County, Arizona. Holotype, USNM 859057; paratypes, USNM 859058.

Common name: Huachuca springsnail.

Distribution: Lower Gila River drainage, southern Arizona; one site in the Rio Magdalena basin (Gulf of California drainage), northern Sonora (Mexico) (Hershler and Landye 1988; Tsai et al. 2007).

Taxonomy: Hershler (1994).

Remarks: Genetic evidence suggests that $P$. thompsoni is paraphyletic relative to $P$. conica and may require taxonomic revision (Hurt 2004). 
Pyrgulopsis torrida Hershler, Liu, Babbitt, Kellogg, and Howard, 2016b: 12-14, figs. 3C, 6. Little Sycamore Canyon, creek $3.2 \mathrm{~km}$ up flow [upflow] from Hwy 1, Ventura County, California. Holotype, SBMNH 74238; paratypes, SBMNH 46092 .

Common name: Little Sycamore pyrg.

Distribution: Known only from the type locality.

\section{Pyrgulopsis transversa Hershler, 1998}

Pyrgulopsis transversa Hershler, 1998: 129-130, figs. 10J, 16G-I, 25H-K, 48D-H. Sixmile Springs, Simpson Mountains, Old River Bed, Tooele County, Utah. Holotype, USNM 883221; paratypes, USNM 860732.

Common name: Southern Bonneville pyrg.

Distribution: West-central Utah (Great Basin).

\section{Pyrgulopsis trivialis (Taylor, 1987)}

Fontelicella trivialis Taylor, 1987: 30-32, fig. 14. Spring-fed pond 1,000 ft [0.305 km] N of SW corner sec. 5, T5N, R29E, Apache County, Arizona. Holotype, LACM 2225.

Pyrgulopsis confluentis Hershler in Hershler and Landye, 1988: 32, 35, figs. 3d-g, 26c, 29-30. Spring on north side of Blanket Creek at Three Forks, Apache County, Arizona. Holotype, USNM 859053.

Common name: Black River springsnail.

Distribution: Two spring complexes in the Black River drainage, lower Colorado River basin, Arizona (Hurt 2004; Martinez and Myers 2008).

Taxonomy: Hershler (1994).

\section{Pyrgulopsis turbatrix Hershler, 1998}

Pyrgulopsis turbatrix Hershler, 1998: 50-53, figs. 6K, 18G-J, 30D-F. Horseshutem Springs, Pahrump Valley, Nye County, Nevada. Holotype, USNM 883978; paratypes, USNM 860699.

Common name: Southwest Nevada pyrg [original name incorrectly given as Southeast Nevada pyrg.]

Distribution: Spring Mountains region, San Bernardino Mountains, central Death Valley region (California, Nevada) (Hershler et al. 2013).

Taxonomy: Hershler et al. (2013). 


\section{Pyrgulopsis umbilicata Hershler, 1998}

Pyrgulopsis umbilicata Hershler, 1998: 81, figs. 8H, 21C-D, 37G-I. Spring near mouth of Warm Springs canyon, Soldier Meadow, Humboldt County, Nevada. Holotype, USNM 873208; paratypes, USNM 860705.

Common name: Southern Soldier Meadow pyrg.

Distribution: Soldier Meadow, Nevada.

\section{Pyrgulopsis variegata Hershler, 1998}

Pyrgulopsis variegata Hershler, 1998: 113-115, figs. 10A, 24A-D, 45A-F. Spring ca. $2.5 \mathrm{~km}$ south of South Patterson Spring, Pilot Valley, Box Elder County, Utah. Holotype, USNM 883627; paratypes, USNM 860723.

Common name: Northwest Bonneville pyrg.

Distribution: North-central Great Basin and one site in the Snake River drainage (Nevada, Utah).

\section{Pyrgulopsis varneri Hershler, Liu, and Sada 2007}

Pyrgulopsis varneri Hershler, Liu, and Sada, 2007b: 176-777, 180, figs. 7, 11. Spring brook north of Mud Meadow Reservoir, Humboldt County, Nevada. Holotype, USNM 1083246; paratypes, USNM 1096917.

Common name: Varners pyrg.

Distribution: Three spring complexes in Soldier Meadow, northeastern Great Basin (Nevada).

\section{Pyrgulopsis ventricosa Hershler, 1995}

Pyrgulopsis ventricosa Hershler, 1995: 367, 369, 372-373, figs. 5G, 23-25. Unnamed creek, Seigler Canyon, $7.4 \mathrm{~km}$ south of HW 29 along Seigler Canyon Road, Lake County, California. Holotype, USNM 860647; paratypes, USNM 883790.

Common name: Clear Lake pyrg.

Distribution: Seigler Creek drainage, south end of the Clear Lake basin (California).

\section{Pyrgulopsis villacampae Hershler, 1998}

Pyrgulopsis villacampae Hershler, 1998: 62-63, figs. 7G, 13A, 19F-G, 33C-E. Little Warm Spring, Duckwater Valley, Nye County, Nevada. Holotype, USNM 873191; paratypes, USNM 860712.

Common name: Duckwater Warm Springs pyrg.

Distribution: Two springs in Duckwater Valley, Nevada. 
Pyrgulopsis vinyardi Hershler, 1998: 84-86, figs, 8K, 21I, 39A-C. Spring, Willow Creek, $1.6 \mathrm{~km}$ southwest of Willow Creek Reservoir, Squaw Valley drainage, Elko County, Nevada. Holotype, USNM 874740; paratypes, USNM 860708.

Common name: Vinyards pyrg.

Distribution: Two springs in the Squaw Valley drainage, north-central Nevada.

\section{Pyrgulopsis wongi Hershler, 1989}

Pyrgulopsis wongi Hershler, 1989: 196, 198-202, figs. 41-46. Unnamed western spring tributary to Pine Creek, Birchim Canyon, Owens Valley, Inyo County, California. Holotype, USNM 860403; paratypes, USNM 857941.

Common name: Wong's springsnail.

Distribution: Several valleys in the southwestern Great Basin (California, Nevada) (Hershler and Pratt 1990; Hershler 1998).

Taxonomy: Hershler (1994).

Remarks: Genetic evidence suggests that $P$. wong $i$ is composed of two evolutionarily distinct lineages and requires taxonomic revision (Liu and Hershler 2007). 


\section{Family Lithoglyphidae Troschel, 1857}

Genus Fluminicola Carpenter, 1864

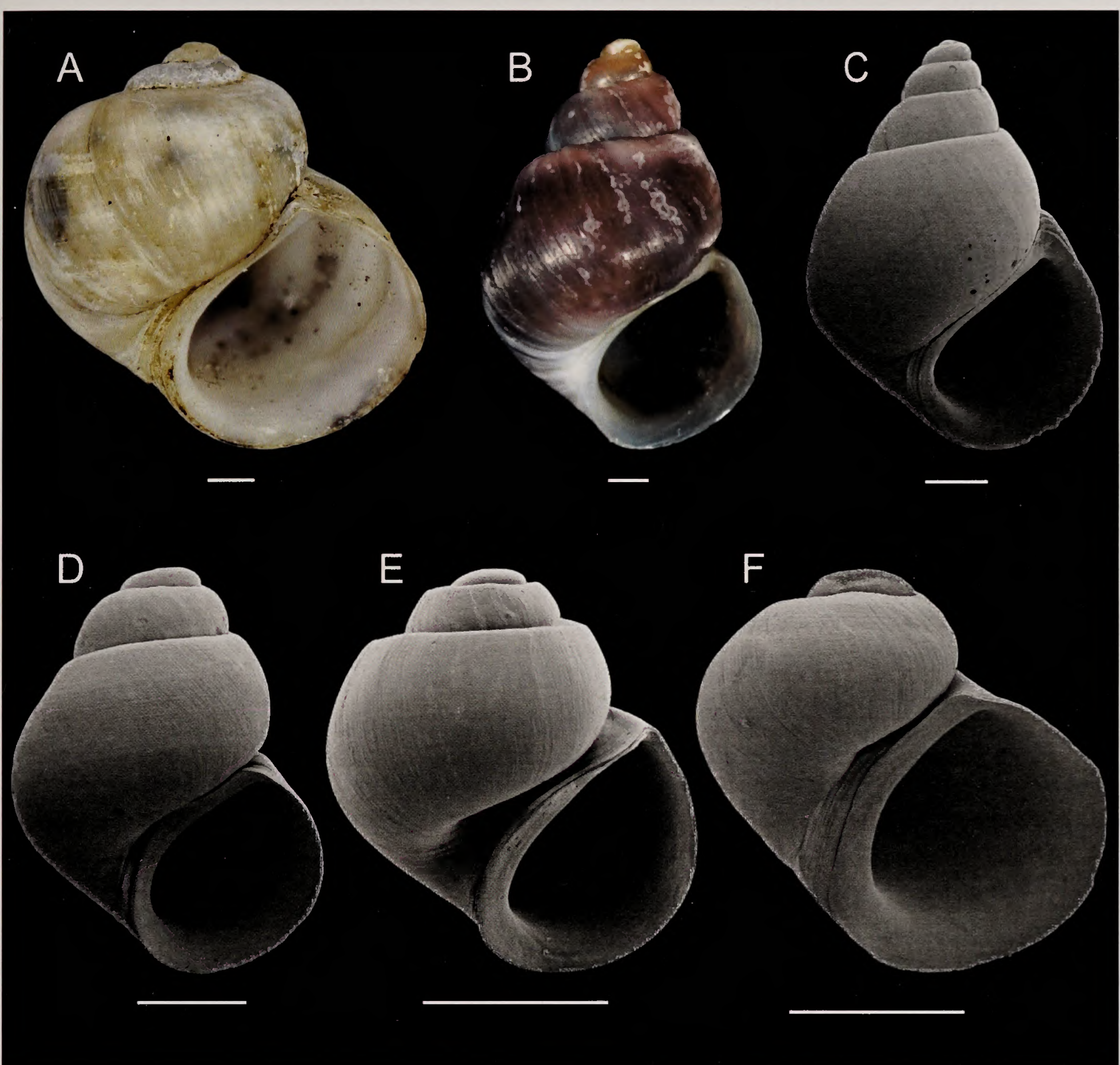

Figure 21. Fluminicola. A. F. nuttallianus, Willamette River, Oregon (USNM 121467 [lectotype]). B. F. coloradoense, Snake River at Clear Lake bridge, Gooding County, Idaho (USNM 905345). C. F. virens, Willamette River, French Prairie State Park, Clackamas County, Oregon (USNM 883183). D. F. warnerensis, Soup Spring, Pit River drainage, Modoc County, California (USNM 1020654). E. F. virginius, spring source of Hardscrabble Creek, Pyramid Lake basin, Washoe County, Nevada (USNM 874105). F. F. neritoides, Springs at Willow Creek Campground, Pit River drainage, Lassen County, California (USNM 883563, holotype). Scale bars, $1.0 \mathrm{~mm}$. 
Fluminicola Carpenter, 1864: 676 [type species: Paludina nuttalliana Lea, 1838; original designation.]

Heathilla Hannibal, 1912: 186-187 [type species: Paludina seminalis Hinds, 1842; original designation].

Remarks: Fluminicola is widely distributed in the northwestern United States and also present in portions of western Canada. Members of this genus typically live in rivers, springs, and large streams and are occasionally found in "spring influenced" lacustrine habitats. Fluminicola is composed of two anatomically distinctive subgroups (Hershler and Frest 1996; Hershler and Liu 2012b), which form evolutionarily distinct and genetically divergent lineages evidenced by mitochondrial DNA data (Hershler and Liu 2012b). One of these is composed of two species from the Snake-Columbia River drainage (F. gustafsoni, F. virens), while the other contains the remaining congeners (for which data are available). This polyphyletic assemblage continues to be classified as a single genus pending resolution of the phylogenetic relationships of the poorly known type species.

\section{Fluminicola ahjumawi Hershler, Liu, Frest, and Johannes, 2007}

Fluminicola ahjumawi Hershler, Liu, Frest, and Johannes, 2007c: 402, 404, figs. 7H, 16.

Spring south of Sam Wolfin Spring, south of Pit River and powerlines, $1.93 \mathrm{~km}$ southwest of Pit 1 Powerhouse, Pacific Gas and Electric land, Shasta County, California. Holotype, USNM 1020691; paratypes, USNM 1020699.

Common name: Sculpin snail.

Distribution: Widely ranging in the lower Pit River basin and also present at one site in the upper Pit River basin, California.

\section{Fluminicola anserinus Hershler, Liu, Frest, and Johannes, 2007}

Fluminicola anserinus Hershler, Liu, Frest, and Johannes, 2007c: 409-410, 412, figs. 6F, 7J, 21. Unnamed spring on west side of Goose Valley Road and Goose Valley, north of Goose Creek ca. $0.8 \mathrm{~km}$, Shasta County, California. Holotype, USNM 1020727; paratypes, USNM 1020728.

Common name: Striated hydrobe.

Distribution: Lower Pit River basin from Lake Britton (including Burney Creek drainage) to vicinity of Chalk Mountain, California. 
Fluminicola caballensis Hershler, Liu, Frest, and Johannes, 2007

Fluminicola caballensis Hershler, Liu, Frest, and Johannes, 2007c: 398, 400, figs. 7F,

14. Davis Creek at crossing of road $0.32 \mathrm{~km}$ south of junction with FS22,

Lassen National Forest, Lassen County, California. Holotype, USNM 1020675;

paratypes, USNM 1020676.

Common name: Horse Creek pebblesnail.

Distribution: Horse Creek and Bob Creek drainages (lower Pit River basin), California.

Fluminicola coloradoense Morrison, 1940

Fluminicola coloradoense Morrison, 1940: 125-126. Green River, Wyoming. Holotype, USNM 526631; paratypes, USNM 526576.

Fluminicola coloradensis.-Hershler and Frest, 1996: 8 [unjustified emendation of coloradoense].

Common name: Green River pebblesnail.

Distribution: Upper Green River basin (Wyoming), northeastern Great Basin

(Idaho, Utah), upper Snake River basin (Idaho, Oregon) (Liu et al. 2013a).

Taxonomy: Hershler and Frest (1996), Liu et al. (2013a).

\section{Fluminicola dalli (Call, 1884)}

Amnicola dalli Call, 1884: 21, 45-47, figs. 2-3, pl. VI: figs. 4-6. Small tributary to Pyramid Lake, near the north end, at Symons Ranch [Nevada]. Lectotype, MCZ 2087; paralectotypes, MCZ 2088.

Common name: Pyramid Lake pebblesnail.

Distribution: Northern portion of the Pyramid Lake basin, Nevada (Hershler and Frest 1996)

Taxonomy: Hershler and Frest (1996).

\section{Fluminicola erosus Hershler, Liu, Frest, and Johannes, 2007}

Fluminicola erosus Hershler, Liu, Frest, and Johannes, 2007c: 394-396, fig. 6C, 7D,

12. Moderate-sized unnamed spring, ca. $0.4 \mathrm{~km}$ southeast of Smokey Charlie

[Charley] Spring and $0.32 \mathrm{~km}$ west of Modoc County 63, at source next to homestead cabin, Modoc County, California. Holotype, 1020663; paratypes, USNM 1020664.

Common name: Smokey Charlie [Charley] pebblesnail.

Distribution: Two closely proximal springs in the upper Pit River basin, California. 
Fluminicola favillaceus Hershler, Liu, Frest, and Johannes, 2007c: 396-398, figs. 6D, 7E, 13. Ash Creek south culvert channel on west side of Ash Valley Road (Modoc County [Highway] 527), Crown D Ranch, Lassen County, California. Holotype, USNM 1020669; paratypes, USNM 1020670.

Common name: Ash Valley pebblesnail.

Distribution: Ash Creek, upper Pit River basin, California.

\section{Fluminicola fremonti Hershler, Liu, Frest, and Johannes, 2007}

Fluminicola fremonti Hershler, Liu, Frest, and Johannes, 2007c: 386, figs. 6A, 7A, 8. Hunters Spring on the north side of FS28, Fremont National Forest [Fremont-Winema National Forest], Lake County, Oregon. Holotype, USNM 1020662; paratypes, USNM 1020661.

Common name: Fremont pebblesnail.

Distribution: Found only at the type locality in the Thomas Creek drainage, Goose Lake basin, Oregon.

\section{Fluminicola fuscus (Haldeman, 1841)}

Anculosa fusca Haldeman, 1841: cover. Oregon. Type has not been located. Amnicola hindsi Baird, 1863: 63. River Kootanie [sic, misspelling of Kootenai].

Lectotype, NHMUK 1863.2.4.17A; paralectotypes, NHMUK 1863.2.4.17.

Fluminicola columbiana Pilsbry, 1899: 125. Columbia River, near Wallula.

Lectotype, ANSP 27767; paralectotypes, ANSP 398349.

Common name: Ashy pebblesnail.

Distribution: Lower Snake River, Columbia River, and large tributaries (Idaho, Oregon, Washington, British Columbia [historically] (Hershler and Frest 1996; Liu et al. 2013a).

Taxonomy: Hershler and Frest (1996).

\section{Fluminicola gustafsoni Hershler and Liu, 2012}

Fluminicola gustafsoni Hershler and Liu, 2012b: 324-325, 327-328, figs. 2-4. Salmon River at Pine Bar Rapids, Idaho County, Idaho. Holotype, USNM 905409; paratypes, USNM 1175400.

Common name: Gustafson pebblesnail [name newly introduced herein]. Distribution: Clearwater River, lower Salmon River, and the short reach of the Snake River between the mouths of these streams (Idaho, Washington). 


\section{Fluminicola insolitus Hershler, 1999}

Fluminicola insolitus Hershler, 1999: 319, 321, figs. 8D, 9, 10A-C. Page Springs, Donner und Blitzen River drainage, Harney County, Oregon. Holotype, USNM 883466; paratypes, USNM 860757.

Common name: Donner und Blitzen pebblesnail.

Distribution: Found only at the type locality.

Fluminicola Iunsfordensis Hershler, Liu, Frest, and Johannes, 2007

Fluminicola lunsfordensis Hershler, Liu, Frest, and Johannes, 2007c: 393-394, figs. 7C, 11. Lunsford Spring above Lunsford Springs Road, source of Canyon Creek, Modoc County, California. Holotype, USNM 1020688; paratypes, USNM 1020689.

Common name: Lunsford pebblesnail.

Distribution: Known only at the type locality in the upper Pit River basin.

\section{Fluminicola minutissimus Pilsbry, 1907}

Fluminicola minutissimus Pilsbry, 1907: 76, pl. XI; fig 4. Price Valley, Weiser Canyon, Washington County, Idaho. Lectotype, ANSP 94273; paralectotypes, ANSP 398350.

Common name: Pixie pebblesnail.

Distribution: Known only from type locality, lower Snake River basin.

Remarks: Fluminicola minutissimus is known only from shells. It has not been collected subsequent to its first discovery and may be extinct (Hershler and Frest 1996).

\section{Fluminicola modoci Hannibal, 1912}

Fluminicola modoci Hannibal, 1912: 187, pl. 8: fig. 30. Fletchers [Fletcher] Spring, south end, Goose Lake, California. Lectotype (and paralectotypes), CAS 60798.

Common name: Modoc pebblesnail.

Distribution: Two springs in the Goose Lake basin (Hershler 1999).

Taxonomy: Hershler and Frest (1996). 
Fluminicola multifarius, Hershler, Liu, Frest, and Johannes, 2007c: 415, 417-419, figs. 7M, 24-25. Big Springs (source) at Big Springs City Park northwest of the city of Mount Shasta, south of Spring Hill, Siskiyou County, California. Holotype, USNM 883782; paratypes, USNM 1020753.

Common name: Shasta pebblesnail.

Distribution: Sacramento River headwater region and upper reaches of the McCloud River drainage, California.

\section{Fluminicola neritoides Hershler, Liu, Frest, and Johannes, 2007}

Fluminicola neritoides Hershler, Liu, Frest, and Johannes, 2007c: 400-402, figs. 6E, 7G, 15. Springs at Willow Creek Campground along CA [Highway] 139, Lassen County, California. Holotype, USNM 883563; paratypes, USNM 1020682.

Common name: Willow Creek pebblesnail.

Distribution: Willow Creek and associated thermal springs (upper Pit River basin), California.

\section{Fluminicola nuttallianus (Lea, 1838)}

Paludina nuttalliana Lea, 1838: 101, pl. XXIII: fig. 89. Wahlamat [sic, misspelling of Willamette] River, near its junction with the Columbia River [Oregon]. Lectotype, USNM 121467; paralectotypes, USNM 860648.

Common name: Dusky pebblesnail.

Distribution: Restricted to the type locality near the mouth of the Willamette River (Oregon).

Taxonomy: Hershler and Frest (1996).

Remarks: This species is known only from shells. It has not been collected for more than 100 years and may be extinct (Hershler and Frest 1996).

\section{Fluminicola potemicus, Hershler, Liu, Frest, and Johannes, 2007}

Fluminicola potemicus, Hershler, Liu, Frest, and Johannes, 2007c: 412-414, figs. 7K, 22. Unnamed spring pool on the west side of FS27 (Fenders Ferry Road), ca. $10.8 \mathrm{rd} \mathrm{km}$ north of CA 299 junction, $4.18 \mathrm{~km}$ north of FS27 bridge over Potem Creek, west side of Potem Creek, inholding in Shasta National Forest [Shasta-Trinity National Forest], Shasta County, California. Holotype, USNM 1020718; paratypes, USNM 1020719.

Common name: Potem Creek pebblesnail.

Distribution: Found only at the type locality. 
Fluminicola scopulinus, Hershler, Liu, Frest, and Johannes, 2007

Fluminicola scopulinus, Hershler, Liu, Frest, and Johannes, 2007c: 414, figs. 7L, 23.

Northernmost of three springs and runs southwest of Popcorn Spring, west side of North Fork Castle Creek, $0.35 \mathrm{~km}$ from FS25 along FS38N35Y (west side), Shasta National Forest, Shasta County, California. Holotype, USNM 1020721 ; paratypes, USNM 1020722.

Common name: Castle Creek pebblesnail.

Distribution: Three closely proximal springs in the Castle Creek drainage, Sacramento River headwaters, California.

\section{Fluminicola seminalis (Hinds, 1842)}

Paludina seminalis Hinds, 1842: 83-84. Rio Sacramento, California. Type has not been located.

Lithoglyphus cumingii Frauenfeld, 1863: 195. California. Lectotype, NHMUK 1993047; paralectotypes, NMW.

Common name: Nugget pebblesnail.

Distribution: Sacramento River basin from near its mouth (historically) upstream into the Pit River basin, California (Taylor 1981; Hershler and Frest 1996; Hershler et al. 2007c).

Taxonomy: Hershler and Frest (1996).

\section{Fluminicola turbiniformis (Tryon, 1865)}

Amnicola turbiniformis Tryon, 1865: 219, pl. 22: fig. 5. West side of Steens Mountains, Harney County, Oregon. Lectotype, ANSP 27779; paralectotypes, ANSP 398352 .

Common name: Turban pebblesnail.

Distribution: Northwestern Great Basin (California, Nevada, Oregon) (Taylor 1966b; Hershler, 1999).

Taxonomy: Hershler and Frest (1996). 
Fluminicola umbilicatus Hershler, Liu, Frest, and Johannes, 2007c: 407, 409, figs. 7I, 19. Big Spring, tributary of Hat Creek, south of Old Station (PO [Post Office]) at the south end of Hat Creek Hill, flowing from beneath CA [Highway] 89/44 on the south side, Lassen National Forest, Shasta County, California. Holotype, USNM 1020705; paratypes, USNM 1020706.

Common name: Goose Valley pebblesnail.

Distribution: Lost Creek and upper section of Hat Creek drainage (lower Pit River basin), California.

\section{Fluminicola virens (Lea, 1838)}

Paludina virens Lea, 1838: 91, pl. XXIII: fig. 93. Wahlamat [sic, misspelling of Willamette] (River), near its junction with the Columbia River [Oregon]. Lectotype, USNM 121431; paralectotypes, USNM 860649.

Paludina nuclea Lea, 1838: 91, pl. XXIII: fig. 103. Wahlamat [sic] (River), near its junction with the Columbia River. Type has not been located.

Common name: Olympia pebblesnail.

Distribution: Willamette River (and large tributary streams), from Corvallis to its mouth; lower Columbia River below Portland (Oregon, Washington) (Hershler and Frest, 1996).

Taxonomy: Hershler and Frest (1996).

\section{Fluminicola virginius Hershler, 1999}

Fluminicola virginius Hershler, 1999: 323-324, figs. 8H, 10D-F, 11. Unnamed

("waterfall") spring, source of Hardscrabble Creek, Pyramid Lake basin,

Washoe County, Nevada. Holotype, USNM 874902; paratypes, USNM 860758.

Common name: Virginia Mountains pebblesnail.

Distribution: Found only at the type locality.

Fluminicola warnerensis Hershler, Liu, Frest, and Johannes, 2007

Fluminicola warnerensis Hershler, Liu, Frest, and Johannes, 2007c: 388, 389, 392-393, figs. 6B, 7B, 10. Parsnip Springs, south of Southern Warner Road (FS64, also designated as 39NO1), in wet, open meadow, Modoc National Forest, Lassen County, California. Holotype, USNM 1020652; paratypes, USNM 1020653.

Common name: Topaz pebblesnail.

Distribution: South Fork Pit River drainage, along Pit River just above Big Valley (California). 


\section{Family Tateidae Thiele, 1925}

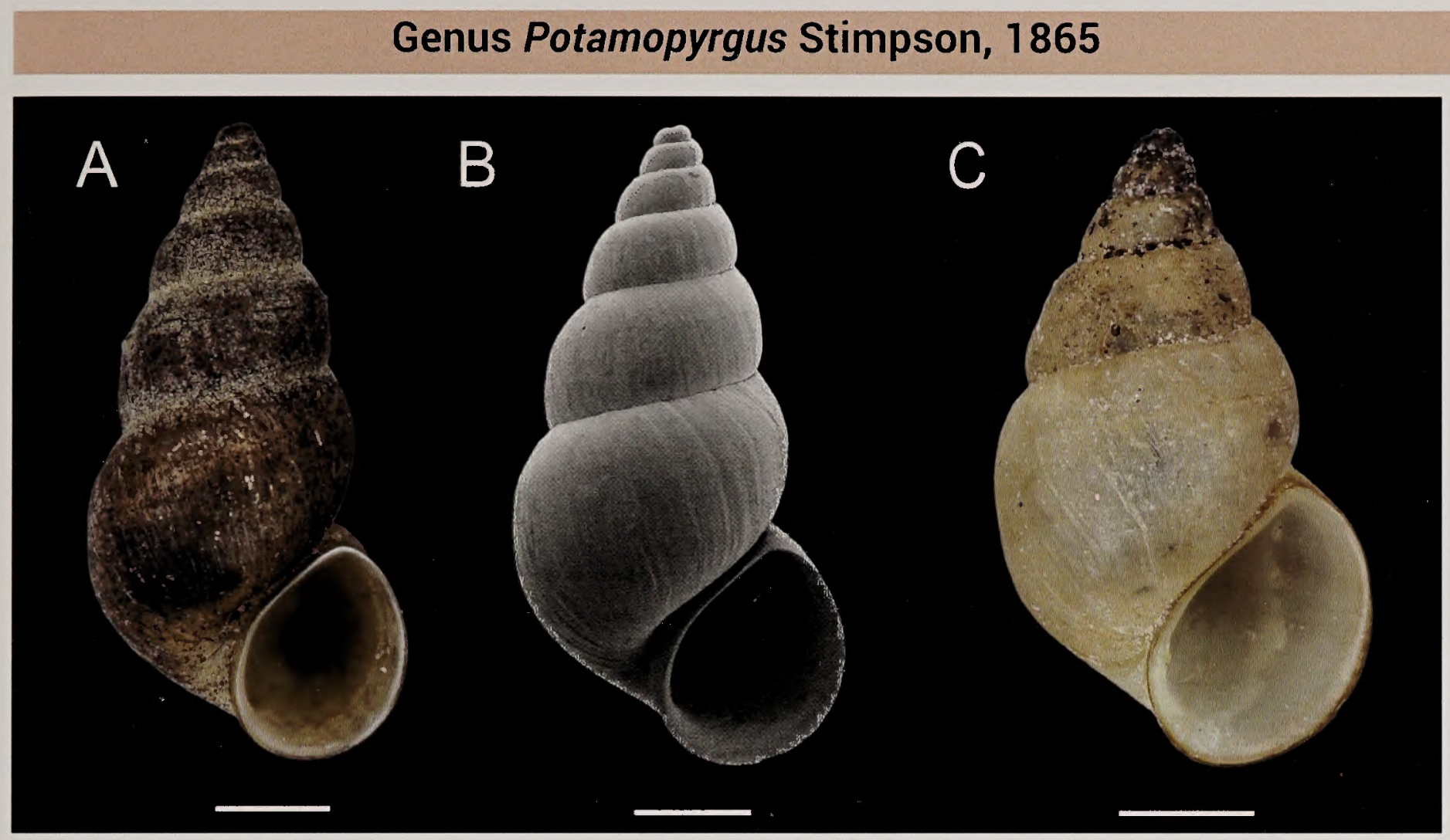

Figure 22. Potamopyrgus antipodarum. A, B. Cassia Creek at Conner Bridge, Snake River drainage, Cassia County, Idaho (USNM 894703). C. Snake River, opposite Pilgrim Spring, Gooding County, Idaho (USNM 1097249). Scale bars, $1.0 \mathrm{~mm}$.

Pomatopyrgus Stimpson, 1865: 53-54 [type species: Melania corolla Gould, 1847; = Amnicola antipodarum Gray, 1843].

\section{Potamopyrgus antipodarum (Gray, 1843)}

Amnicola antipodanum [sic] Gray, 1843: 241. New Zealand, in fresh water. Syntypes, NHMUK (per Ponder 1988).

Amnicola antipodarum Gray, 1844: 356 [correction of original spelling].

Common name: New Zealand mudsnail.

Distribution: Native to New Zealand (Ponder 1988), widely introduced in Australia, Europe, North America, and parts of Asia (Alonso and Castro-Díez 2012).

Recorded from all of the western United States except New Mexico (USGS 2016).

Remarks: See Ponder (1988) for a list of the numerous (extralimital) junior synonyms of this species. 


\section{Family uncertain}

\section{Genus Pristinicola Hershler, Frest, Johannes, Bowler, and Thompson, 1994}

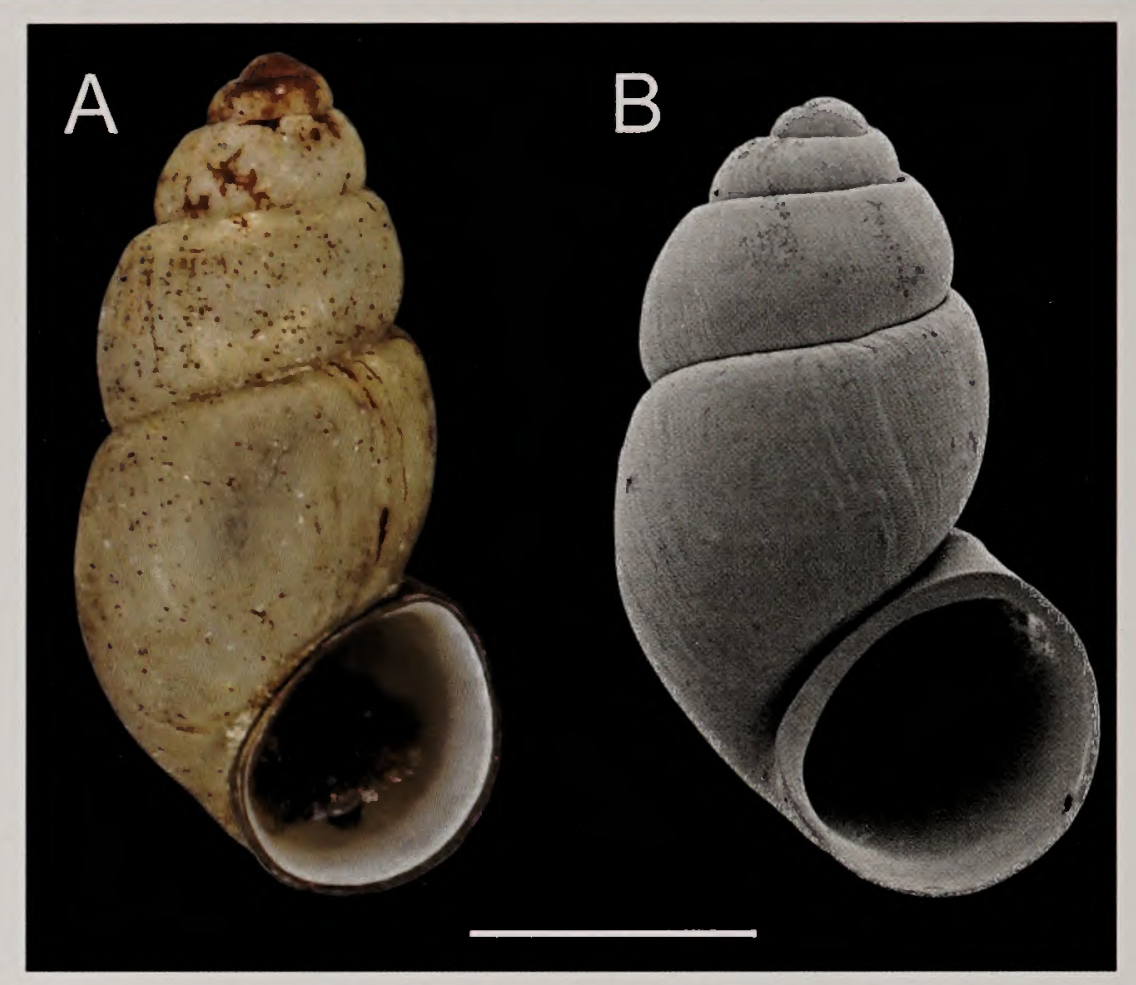

Figure 23. Pristinicola hemphilli. A. Mountain springs, Silvies River drainage, Grant County, Oregon (USNM 883878). B. Spring, Price Valley, $4.8 \mathrm{~km}$ northwest of Hwy 95, Adams County, Idaho (USNM 874184). Scale bar, $1.0 \mathrm{~mm}$.

Pristinicola Hershler, Frest, Johannes, Bowler, and Thompson, 1994: 222-225

[type species: Bythinella hemphilli Pilsbry, 1890; original designation].

Remarks: Pristinicola is a monotypic genus that is distributed in the northwestern United States. It cannot be assigned to any currently recognized truncatelloidean family and does not appear to be closely related to other North American taxa (Hershler et al. 1994; Hershler and Liu 2012b).

\section{Pristinicola hemphilli (Pilsbry, 1890)}

Bythinella hemphilli Pilsbry, 1890: 63-64. Near Kentucky Ferry, Snake River, Washington [precise location unknown]. Lectotype, ANSP 32276; paralectotypes,

ANSP 368405.

Common name: Pristine pyrg.

Distribution: Lower Snake River and Columbia River basins (Idaho, Oregon, Washington), minor Pacific Coastal drainages (Washington) (Hershler et al. 1994).

Taxonomy: Hershler et al. (1994). 
Genus Taylorconcha Hershler, Frest, Johannes, Bowler, and Thompson, 1994

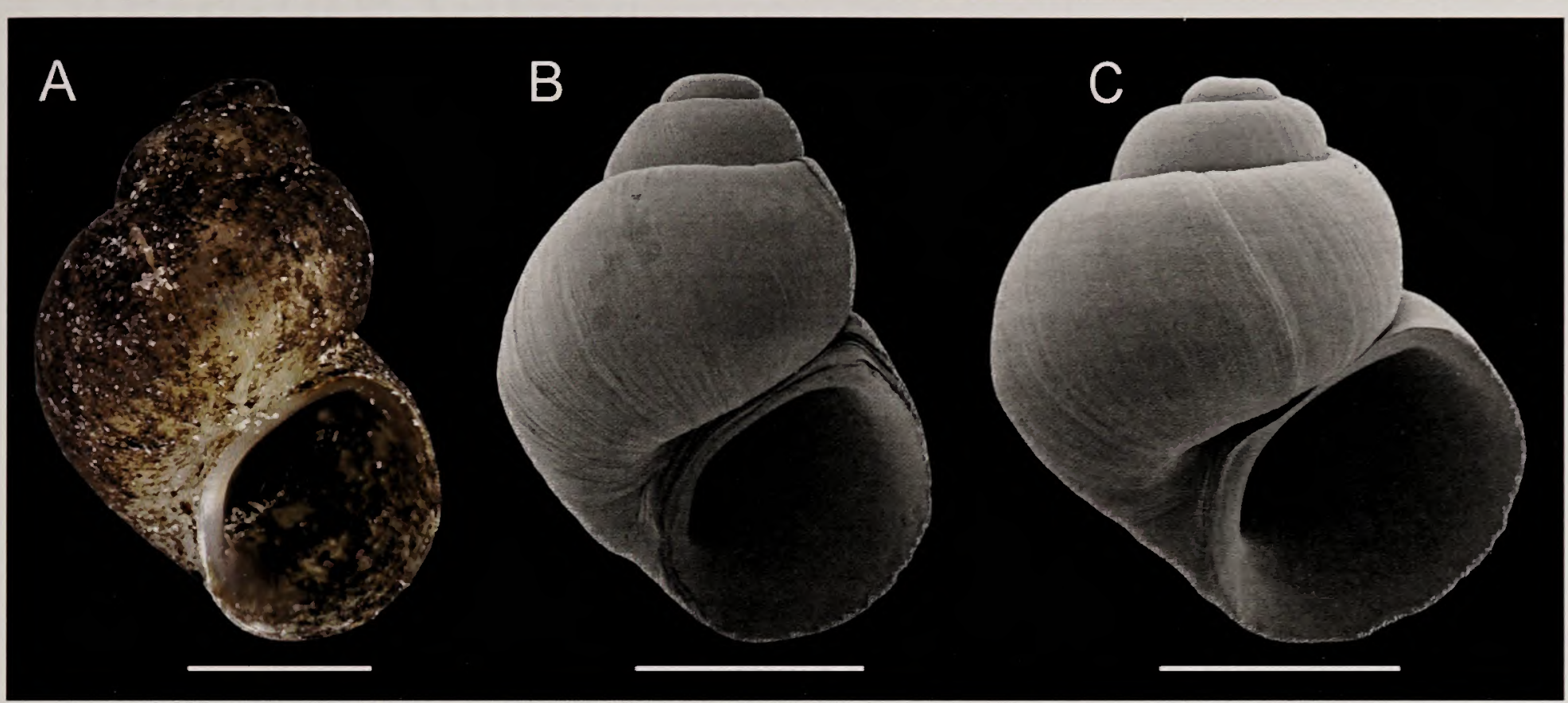

Figure 24. Taylorconcha. A. T. serpenticola, Snake River at Clover Creek confluence, Elmore County, Idaho (USNM 874590). B. T. serpenticola, Thousand Springs (north springs), Snake River drainage, Gooding County, Idaho (USNM 874588 [paratype]). C. T. insperata, Owyhee River at the Cave, Malheur County, Oregon (USNM 1018182 [holotype]). Scale bars, $1.0 \mathrm{~mm}$.

Taylorconcha Hershler, Frest, Johannes, Bowler, and Thompson, 1994: 233

[type species: Taylorconcha serpenticola Hershler, Frest, Johannes, Bowler and Thompson, 1994; original designation.]

Remarks: Taylorconcha is distributed in the Owyhee River and in the Snake River and associated springs. This genus is morphologically similar to the lithoglyphids (Hershler et al. 1994) and was delineated as sister to the lithoglyphid clade in a recent analysis of COI sequence data (Hershler and Liu 2012b); additional studies that include a broader range of truncatelloidean taxa are needed to confidently ascertain its relationships.

Taylorconcha insperata Hershler, Liu, Frest, Johannes, and Clark, 2006

Taylorconcha insperata Hershler, Liu, Frest, Johannes, and Clark, 2006: 175, figs. 6B, 7-8. Owyhee River at the Cave, 1.6 river km below the mouth of Big Antelope Creek at river km 269.4, Malheur County, Oregon. Holotype, USNM 1018182; paratypes, USNM 1071513.

Common name: Unexpected pebblesnail.

Distribution: Middle Owyhee River and lower Snake River (Hells Canyon) (Idaho, Oregon). 


\section{Taylorconcha serpenticola Hershler, Frest, Johannes, Bowler, and Thompson, 1994}

Taylorconcha serpenticola Hershler, Frest, Johannes, Bowler, and Thompson, 1994: 233, 235, 237, 239, 240-242, figs. 1 (bottom row), 8-12. Thousand Springs (north springs), Gooding County, Idaho. Holotype, USNM 860583; paratypes, UF 194616, USNM 874588.

Common name: Bliss Rapids snail.

Distribution: Snake River and associated springs between Twin Falls and the Indian Cove Bridge, Idaho (Hershler et al. 1994). 


\section{Literature Cited}

Alonso, A., Castro-Díez, P. 2012. The exotic aquatic mud snail Potamopyrgus antipodarum (Hydrobiidae, Mollusca): state of the art of a worldwide invasion. Aquatic Sciences 74:375-383.

ANS [Aquatic Nuisance Species] Task Force. 2005. New Zealand mudsnail (Potamopyrgus antipodarum). Available from http://www.anstaskforce.gov/ spoc/nzms.php (accessed 3/2/2016).

Arnold, R. 1903. The paleontology and stratigraphy of the marine Pliocene and Pleistocene of San Pedro, California. Memoirs of the California Academy of Sciences 3:1-420, 37 plates.

Baily, J.L. Jr., Baily, R.I. 1951. Further observations on the Mollusca of the relict lakes in the Great Basin. Nautilus 65(2):46-53, pl. 4.

Baily, J.L. Jr., Baily, R.I. 1952. Amnicola pilsbryana, new name. Nautilus 65(4):144.

Baird, W. 1863. Descriptions of some new species of shells, collected at Vancouver Island and in British Columbia, by J.K. Lord, Esq., naturalist to the British North-American Boundary Commission, in the years 1858-1862. Proceedings of the Zoological Society of London 31:66-70.

Berry, S.S. 1947. A new Pyrgulopsis from Oregon. Nautilus 60:76-78, pl. 7: figs. 6-7.

Burch, J.B. 1982. North American freshwater snails. Identification keys, generic synonymy, supplemental notes, glossary, references, index. Walkerana 1:217365.

Burch, J.B., Tottenham, J.L. 1980. North American freshwater snails. Species list, ranges and illustrations. Walkerana 1:81-215.

Calkins, W.W. 1880. New freshwater Mollusca. Valley Naturalist 2:6.

Call, R.E. 1884. On the Quaternary and Recent Mollusca of the Great Basin with descriptions of new forms; introduced by a sketch of the Quaternary lakes of the Great Basin by G.K. Gilbert. United States Geological Survey Bulletin 11:1-66.

Call, R.E., Pilsbry, H.A. 1886. On Pyrgulopsis, a new genus of rissoid mollusk, with descriptions of two new forms. Proceedings of the Davenport Academy of Natural Sciences 5:9-14. 
Carpenter, P.P. 1864. Supplementary report on the present state of our knowledge with regard to the Mollusca of the west coast of North America. Report of the British Association for the Advancement of Science 33:517-686.

Chamberlain, R.V., Berry, E. 1933. Mollusks of the Pliocene deposits at Collinston, Utah. Nautilus 47:25-29.

Clarke, A.H. 1981. The freshwater molluscs of Canada. Ottawa, Canada: National Museum of Natural Sciences, National Museums of Canada. 446 p.

Conrad, T.A. 1855. Description of a new species of Melania. Proceedings of the Academy of Natural Sciences of Philadelphia 7:269.

Cowie, R.H. 1997. Catalog and bibliography of the nonindigeneous nonmarine snails and slugs of the Hawaiian Islands. Bishop Museum Occasional Papers 50:1-66.

Davis, G.M., Mazurkiewicz, M., Mandracchia, M. 1982. Spurwinkia: morphology, systematics, and ecology of a new genus of North American marshland Hydrobiidae (Mollusca: Gastropoda). Proceedings of the Academy of Natural Sciences of Philadelphia 134:143-177.

Frauenfeld, G.R. von. 1863. Die Arten der Gattung Lithoglyphus Mhlf., Paludinella Pf., Assiminea Gray, in der Kaiserlichen und Cuming's Sammlung. Verhandlungen der Kaiserlich-Königlichen Zoologische-Botanischen Gesellschaft in Wien 13:193-212.

Gill, T. 1863. Systematic arrangement of the mollusks of the family Viviparidae, and others, inhabiting the United States. Proceedings of the Academy of Natural Sciences of Philadelphia 15:33-40.

Gould, A.A. 1839. [Descriptions of thirteen new species of shells.] Silliman's American Journal of Science and Arts 38:196-197.

Gould, A.A. 1847. [Shells collected by the United States Exploring Expedition under the command of Charles Wilkes.] Proceedings of the Boston Society of Natural History 2:222-225.

Gould, A.A. 1855. New species of land and fresh-water shells from western (N.) America. Proceedings of the Boston Society of Natural History 5:127-130.

Gray, J.E. 1840. Mollusks. In: British Museum, Synopsis of the contents of the British Museum. 42nd edition. London: G. Woodfall and Son:86-89, 106-156. 
Gray, J.E. 1843. Catalogue of the species of Mollusca and their shells, which have hitherto been recorded as found at New Zealand, with the description of some lately discovered species. In: E. Dieffenbach, Travels in New Zealand; with contributions to the geography, geology, botany, and natural history of that country. Volume II. London: John Murray:228-265.

Gray, J.E. 1844. Catalogue des Mollusques et do leurs Coquilles, trouvés jusqu’à présent à la Nouvelle-Zélande, avec la description des espèces récemment découvertes. Revue Zoologique 7:346-358.

Gregg, W.O., Taylor, D.W. 1965. Fontelicella (Prosobranchia: Hydrobiidae), a new genus of west American freshwater snails. Malacologia 3:103-110.

Haldeman, S.S. 1840. A monograph of the Limniades and other freshwater univalve shells of North America. No. 1. Philadelphia: J. Dobson: 3.

Haldeman, S.S. 1841. A monograph of the Limniades and other freshwater univalve shells of North America. No. 3. Philadelphia: J. Dobson: cover.

Haldeman, S.S. 1844. A monograph of the freshwater univalve mollusca of the United States, including notices of species in other parts of North America. No. 7. Philadelphia: Carey and Hart: cover.

Hannibal, H. 1912. A synopsis of the Recent and Tertiary freshwater Mollusca of the Californian province, based upon an ontogenetic classification. Proceedings of the Malacological Society of London 10:112-211.

Herrmannsen, A.N. 1846. Indicis generum malacozoorum primordia. Nomina subgenerum, generum, familiarum, tribuum, ordinum, classium; adjectis auctoribus, temporibus, locis systematicis atque literariis, etymis, synonymis. Praetermittuntur Cirripedia, Tunicata et Rhizopoda. Volume 1. Cassellis: Sumptibus and Typis Theodori Fischeri. 637 p.

Hershler, R. 1985. Systematic revision of the Hydrobiidae (Gastropoda: Rissoacea) of the Cuatro Cienegas basin, Coahuila, Mexico. Malacologia 26:31-123.

Hershler, R. 1989. Springsnails (Gastropoda: Hydrobiidae) of Owens and Amargosa River (exclusive of Ash Meadows) drainages, Death Valley system, CaliforniaNevada. Proceedings of the Biological Society of Washington 102:176-248.

Hershler, R. 1990. Pyrgulopsis bruneauensis, a new springsnail (Gastropoda: Hydrobiidae) from the Snake River Plain, southern Idaho. Proceedings of the Biological Society of Washington 103:803-814. 
Hershler, R. 1994. A review of the North American freshwater snail genus Pyrgulopsis (Hydrobiidae). Smithsonian Contributions to Zoology 554:1-115.

Hershler, R. 1995. New freshwater snails of the genus Pyrgulopsis (Rissooidea: Hydrobiidae) from California. Veliger 38:343-373.

Hershler, R. 1998. A systematic review of the hydrobiid snails (Gastropoda: Rissooidea) of the Great Basin, western United States. Part I. Genus Pyrgulopsis. Veliger 41:1-132.

Hershler, R. 1999. A systematic review of the hydrobiid snails (Gastropoda: Rissooidea) of the Great Basin, western United States. Part II. Genera Colligyrus, Eremopyrgus, Fluminicola, Pristinicola, and Tryonia. Veliger 42:306-337.

Hershler, R. 2001. Systematics of the North and Central American aquatic snail genus Tryonia (Rissooidea: Hydrobiidae). Smithsonian Contributions to Zoology 612:1-53.

Hershler, R., Davis, C.L., Kitting, C.L., Liu, H.-P. 2007a. Discovery of introduced and cryptogenic cochliopid gastropods in the San Francisco Estuary, California. Journal of Molluscan Studies 73:323-332.

Hershler, R., Frest, T.J. 1996. A review of the North American freshwater snail genus Fluminicola (Hydrobiidae). Smithsonian Contributions to Zoology 583:1-41.

Hershler, R., Frest, T.J., Johannes, E.J., Bowler, P.A., Thompson, F.G. 1994. Two new genera of hydrobiid snails (Prosobranchia: Rissooidea) from the northwestern United States. Veliger 37:221-243.

Hershler, R., Frest, T.J., Liu, H.-P., Johannes, E.J. 2003a. Rissooidean snails from the Pit River basin, California. Veliger 46:275-304.

Hershler, R., Landye, J.J. 1988. Arizona Hydrobiidae. Smithsonian Contributions to Zoology 459:1-63.

Hershler, R., Liu, H.-P. 2004a. Taxonomic reappraisal of species assigned to the North American freshwater gastropod subgenus Natricola (Rissooidea: Hydrobiidae). Veliger 47:66-81.

Hershler, R., Liu, H.-P. 2004b. A molecular phylogeny of aquatic gastropods provides a new perspective on biogeographic history of the Snake River region. Molecular Phylogenetics and Evolution 32:927-937. 
Hershler, R., Liu, H.-P. 2008. Ancient vicariance and recent dispersal of springsnails (Hydrobiidae: Pyrgulopsis) in the Death Valley system, California-Nevada. In: Reheis, M.C., Hershler, R., Miller, D.M., eds. Late Cenozoic drainage history of the southwestern Great Basin and lower Colorado River region: geologic and biotic perspectives. Geological Society of America Special Paper 439:91-101.

Hershler, R., Liu, H.-P. 2009. New species and records of Pyrgulopsis (Gastropoda: Hydrobiidae) from the Snake River basin, southeastern Oregon: further delineation of a highly imperiled fauna. Zootaxa 2006:1-22.

Hershler, R., Liu, H.-P. 2010. Two new, possibly threatened species of Pyrgulopsis (Gastropoda: Hydrobiidae) from southwestern California. Zootaxa 2343:1-17.

Hershler, R., Liu, H.-P. 2012a. A new species of springsnail (Pyrgulopsis) from the Owyhee River basin, Nevada. Western North American Naturalist 72:21-31.

Hershler, R., Liu, H.-P. 2012b. Molecular phylogeny of the western North American pebblesnails, genus Fluminicola (Rissooidea: Lithoglyphidae), with description of a new species. Journal of Molluscan Studies 78:321-329.

Hershler, R., Liu, H.-P., Babbitt, C., Kellogg, M.G., Howard, J.K. 2016a. 'Three new species of western California springsnails previously confused with Pyrgulopsis stearnsiana (Caenogastropoda, Hydrobiidae). ZooKeys 601:1-19.

Hershler, R., Liu, H.-P., Bradford, C. 2013. Systematics of a widely distributed western North American springsnail, Pyrgulopsis micrococcus (Caenogastropoda, Hydrobiidae), with descriptions of three new congeners. Zookeys 330:27-52.

Hershler, R., Liu, H.-P., Carlton, J.T., Cohen, A.N., Davis, C.B., Sorensen, J., Weedman, D. 2015a. New discoveries of introduced and cryptogenic fresh and brackish water gastropods (Caenogastropoda: Cochliopidae) in the western United States. Aquatic Invasions 10:147-156.

Hershler, R., Liu, H.-P., Frest, T.J., Johannes, E.J. 2007c. Extensive diversification of pebblesnails (Lithoglyphidae: Fluminicola) in the upper Sacramento River basin, northwestern USA. Zoological Journal of the Linnean Society 149:371-422.

Hershler, R., Liu, H.-P., Frest, T.J., Johannes, E.J., Clark, W.H. 2006. Genetic structure of the western North American aquatic gastropod genus Taylorconcha and description of a second species. Journal of Molluscan Studies 72:167-177. 
Hershler, R., Liu, H.-P., Gustafson, D.L. 2008. A second species of Pyrgulopsis (Hydrobiidae) from the Missouri River basin, with molecular evidence supporting faunal origin through Pliocene stream capture across the northern continental divide. Journal of Molluscan Studies 74:403-413.

Hershler, R., Liu, H.-P., Howard, J. 2014a. Springsnails: a new conservation focus in western North America. Bioscience 64:693-700.

Hershler, R., Liu, H.-P., Landye, J.J. 2002. A new species of Eremopyrgus (Hydrobiidae: Cochliopinae) from the Chihuahuan Desert, Mexico: phylogenetic relationships and biogeography. Journal of Molluscan Studies 68:7-15.

Hershler, R., Liu, H.-P., Landye, J.J. 2011. Two new genera and four new species of freshwater cochliopid gastropods (Rissooidea) from northeastern Mexico. Journal of Molluscan Studies 77:8-23.

Hershler, R., Liu, H.-P., Mulvey, M. 1999b. Phylogenetic relationships within the aquatic snail genus Tryonia: implications for biogeography of the North American Southwest. Molecular Phylogenetics and Evolution 13:377-391.

Hershler, R., Liu, H.-P., Sada, D.W. 2007b. Origin and diversification of the Soldier Meadow springsnails (Hydrobiidae: Pyrgulopsis), a species flock in the northwestern Great Basin, United States. Journal of Molluscan Studies 73:167-183.

Hershler, R., Liu, H.-P., Simpson, J.S. 2015b. Assembly of a micro-hotspot of caenogastropod endemism in the southern Nevada desert, with a description of a new species of Tryonia (Truncatelloidea, Cochliopidae).

ZooKeys 492:107-122.

Hershler, R., Liu, H.-P., Stevens, L.E. 2016b. A new springsnail (Hydrobiidae: Pyrgulopsis) from the lower Colorado River basin, northwestern Arizona. Western North American Naturalist 76:72-81.

Hershler, R., Liu, H.-P., Thompson, F.G. 2003b. Phylogenetic relationships of North American nymphophiline gastropods based on mitochondrial DNA sequences. Zoologica Scripta 32:357-366.

Hershler, R., Mulvey, M., Liu, H.-P. 1999a. Biogeography in the Death Valley region: evidence from springsnails (Hydrobiidae: Tryonia). Zoological Journal of the Linnean Society 126:335-354. 
Hershler, R., Mulvey, M., Liu, H.-P. 2005. Genetic variation in the desert springsnail (Tryonia porrecta): implications for reproductive mode and dispersal. Molecular Ecology 14:1755-1765.

Hershler, R., Ponder, W.F. 1998. A review of morphological characters of hydrobioid snails. Smithsonian Contributions to Zoology 600:1-55. Available from https://repository.si.edu/handle/10088/5530 (accessed 4/17/2017).

Hershler, R., Pratt, W.L. 1990. A new Pyrgulopsis (Gastropoda: Hydrobiidae) from southeastern California, with a model for historical development of the Death Valley hydrographic system. Proceedings of the Biological Society of Washington 103:279-299.

Hershler, R., Ratcliffe, V., Liu, H.-P., Lang, B., Hay, C. 2014b. Taxonomic revision of the Pyrgulopsis gilae (Caenogastropoda: Hydrobiidae) species complex, with descriptions of two new species from the Gila River basin, New Mexico. ZooKeys 429:69-85.

Hershler, R., Sada, D.W. 1987. Springsnails (Gastropoda: Hydrobiidae) of Ash Meadows, Amargosa basin, California-Nevada. Proceedings of the Biological Society of Washington 100:776-843.

Hershler, R., Sada, D.W. 2000. A new species of hydrobiid snail of the genus Pyrgulopsis from northwestern Nevada. Veliger 43:367-375.

Hershler, R., Thompson, F.G. 1987. North American Hydrobiidae (Gastropoda: Rissoacea): redescription and systematic relationships of Tryonia Stimpson, 1865 and Pyrgulopsis Call and Pilsbry, 1886. Nautilus 101:25-32.

Hershler, R., Thompson, F.G. 1992. A review of the aquatic gastropod subfamily Cochliopinae (Prosobranchia: Hydrobiidae). Malacological Review Supplement 5:1-140.

Hinds, R.B. 1842. Descriptions of new shells. Annals and Magazine of Natural History 10:81-84.

Hurt, C.R. 2004. Genetic divergence, population structure and historical demography of rare springsnails (Pyrgulopsis) in the lower Colorado River basin. Molecular Ecology 13:1173-1187. 
Johnson, P.D., Bogan, A.E., Brown, K.M., Burkhead, N.M., Cordeiro, J.R., Garner, J.T., Hartfield, P.D., Lepitzki, D.A.W., Mackie, G.L., Pip, E., Tarpley, T.A., Tiemann, J.S., Whelan, N.V., Strong, E.E. 2013. Conservation status of freshwater gastropods of Canada and the United States. Fisheries 38:247-282.

Kabat, A.R., Hershler, R. 1993. The prosobranch snail family Hydrobiidae (Gastropoda: Rissooidea): review of classification and supraspecific taxa. Smithsonian Contributions to Zoology 547:1-94.

Lea, I. 1838. Description of new freshwater and land shells. Transactions of the American Philosophical Society 6(1):1-154.

Lea, I. 1844. On fresh water and land shells. Proceedings of the American Philosophical Society 2:30-35.

Liu, H.-P., Hershler, R. 2005. Molecular systematics and radiation of western North American nymphophiline gastropods. Molecular Phylogenetics and Evolution 34:284-298.

Liu, H.-P., Hershler, R. 2007. A test of the vicariance hypothesis of western North American freshwater biogeography. Journal of Biogeography 34:534-548.

Liu, H.-P., Hershler, R. 2012. Phylogeography of an endangered western North American springsnail. Conservation Genetics 13:299-305.

Liu, H.-P., Hershler, R. 2014. Microsatellite primers for a western North American springsnail (Pyrgulopsis robusta): evidence for polyploidy and crossamplification in P. bruneauensis. Journal of Molluscan Studies 80:107-110.

Liu, H.-P., Hershler, R., Clift, K. 2003. Mitochondrial DNA sequences reveal extensive cryptic diversity within a western American springsnail. Molecular Ecology 12:2771-2782.

Liu, H.-P., Hershler, R., Lang, B., Davies, J. 2013b. Molecular evidence for cryptic species in a narrowly endemic western North American springsnail (Pyrgulopsis gilae). Conservation Genetics 14:917-923.

Liu, H.-P., Hershler, R., Rossel, C.S. 2015a. Taxonomic status of the Columbia duskysnail (Truncatelloidea, Amnicolidae, Colligyrus). ZooKeys 514:1-13.

Liu, H.-P., Hovingh, P., Hershler, R. 2015b. Genetic evidence for recent spread of springsnails (Hydrobiidae: Pyrgulopsis) across the Wasatch Divide. Western North American Naturalist 75:325-331. 
Liu, H.-P., Marceau, D., Hershler, R. 2016. Taxonomic identity of two amnicolid gastropods of conservation concern in lakes of the Pacific Northwest of the USA. Journal of Molluscan Studies 82:464-471.

Liu, H.-P., Walsh, J., Hershler, R. 2013a. Taxonomic clarification and phylogeography of Fluminicola coloradensis Morrison, a widely ranging western North American pebblesnail. Monographs of the Western North American Naturalist 6:87-110.

Lysne, S.J., Riley, L.A., Clark, W.H. 2007. The life history, ecology, and distribution of the Jackson Lake springsnail (Pyrgulopsis robusta Walker 1908). Journal of Freshwater Ecology 22:647-653.

McAlpine, D.F., Bateman, D., Davis, C.A. 2005. Spurwinkia salsa (Pilsbry 1905) (Gastropoda: Hydrobiid) in the Kennebecasis Estuary, New Brunswick: a brackish-water snail new to Canada. Journal of Conchology 38:602-604.

Martinez, M.A., Myers, T.L. 2008. Associations between aquatic habitat variables and Pyrgulopsis trivialis presence/absence. Journal of Freshwater Ecology 23: 189-194.

Mighels, J.W. 1848. Description of shells from the Sandwich Islands, and other localities. Proceedings of the Boston Society of Natural History 2:18-25.

Morrison, J.P.E. 1940. A new species of Fluminicola with notes on "Colorado Desert" shells, and on the genus Clappia. Nautilus 53:124-127.

Morrison, J.P.E. 1945. Durangonella, a new hydrobiine genus from Mexico, with three new species. Nautilus 59:18-23; pl. 3.

Pilsbry, H.A. 1890. Notices of new Amnicolidae. Nautilus 4:63-64.

Pilsbry, H.A. 1892. Preliminary notices of new forms of fresh water mollusks. Nautilus 5:142-143.

Pilsbry, H.A. 1899. Catalogue of the Amnicolidae of the western United States. Nautilus 12:121-127.

Pilsbry, H.A. 1905. A new brackish-water snail from New England. Nautilus 19:90-91, pl. III: fig. 10.

Pilsbry, H.A. 1907. A new species of Fluminicola. Nautilus 21:75-76. 
Pilsbry, H.A. 1916. New species of Amnicola from New Mexico and Utah. Nautilus 29:111-112.

Pilsbry, H.A. 1933. Amnicolidae from Wyoming and Oregon. Nautilus 47:9-12, pl. 2: figs. 1-10.

Pilsbry, H.A. 1934. Pliocene fresh-water fossils of the Kettleman Hills and neighboring Californian oil fields. Nautilus 48:15-17.

Pilsbry, H.A. 1935. Western and southwestern Amnicolidae and a new Humboldtiana. Nautilus 48:91-94.

Pilsbry, H.A. 1952. Littoridina tenuipes (Couper). Nautilus 66:50-54.

Ponder, W.F. 1988. Potamopyrgus antipodarum-a molluscan colonizer of Europe and Australia. Journal of Molluscan Studies 54:271-285.

Say, T. 1817. Descriptions of new species of land and fresh water shells of the United States. Journal of the Academy of Natural Sciences of Philadelphia 1:123-126.

Say, T. 1821. Descriptions of univalve shells of the United States. Journal of the Academy of Natural Sciences of Philadelphia 2:149-179.

Stearns, R.E.C. 1883. Description of a new hydrobiinoid gasteropod [sic] from the mountain lakes of the Sierra Nevada, with remarks on allied species and the physiographical features of said region. Proceedings of the Academy of Natural Sciences of Philadelphia 35:171-176.

Stearns, R.E.C. 1893. Report on the land and fresh-water shells collected in California and Nevada by the Death Valley Expedition, including a few additional species obtained by Dr. C. Hart Merriam and assistants in parts of the southwestern United States. North American Fauna 7:269-283.

Stimpson, W. 1865. Diagnoses of newly discovered genera of gasteropods [sic], belonging to the sub-fam. Hydrobiinae, of the family Rissoidae. American Journal of Conchology 1:52-54.

Taylor, D.W. 1950. Three new Pyrgulopsis from the Colorado Desert, California. Leaflets in Malacology 1:27-33.

Taylor, D.W. 1966a. A remarkable snail fauna from Coahuila, México. Veliger 9:152-228. 
Taylor, D.W. 1966b. Summary of North American Blancan nonmarine mollusks. Malacologia 4:1-172.

Taylor, D.W. 1975. Index and bibliography of late Cenozoic freshwater Mollusca of western North America. University of Michigan Papers on Paleontology 10:1-384.

Taylor, D.W. 1981. Freshwater mollusks of California: a distributional checklist. California Fish and Game 67:140-163.

Taylor, D.W. 1987. Fresh-water molluscs from New Mexico and vicinity. Bulletin of the New Mexico Bureau of Mines and Mineral Resources 116:1-50.

Taylor, D.W., Bright, R.C. 1987. Drainage history of the Bonneville basin. In: Kopp, R.S., Cohenour, R.E., eds. Cenozoic geology of western Utah; sites for precious metal and hydrocarbon accumulations. Utah Geological Association Publication 16:239-256.

Thiele, J. 1925. Mollusca = Weichtiere. In: Kukenthal, W., Krumbach, T., eds. Handbuch der Zoologie, eine Naturgeschichte der Stämme des Tierreiches. Volume 5. Berlin and Leipzig: Walter de Gruyter and Co.:15-96, figures 8-109.

Thompson, F.G. 1968. The aquatic snails of the family Hydrobiidae of peninsular Florida. Gainesville: University of Florida Press. 268 p.

Thompson, F.G., Hershler, R. 1991. Two new hydrobiid snails (Amnicolinae) from Florida and Georgia, with a discussion of the biogeography of freshwater gastropods of south Georgia streams. Malacological Review 24:55-72.

Thompson, F.G., Hershler, R. 2002. Two genera of North American freshwater snails: Marstonia Baker, 1926, resurrected to generic status, and Floridobia, new genus (Prosobranchia: Hydrobiidae: Nymphophilinae). Veliger 45:269-271.

Troschel, F. H. 1857. Das Gebiss der Schnecken zur Begrundung Einer Naturlichen Classification. Erster Band, Part 1. Berlin: Nicolaische Verlagsbuchhandlung:73-112, plates 5-8.

Tryon, G.W. 1863. Notes on American fresh water shells, with descriptions of two new species. Proceedings of the Academy of the Natural Sciences of Philadelphia 14:451-452.

Tryon, G.W. 1865. Descriptions of new species of Amnicola, Pomatiopsis, Somatogyrus, Gabbia, Hydrobia, and Rissoa. American Journal of Conchology 1:219-222. 
Tryon, G.W. 1866. [Review of "Researches upon the Hydrobiinae and allied forms by Dr. Wm. Stimpson."] American Journal of Conchology 2:152-158.

Tsai, Y.J., Maloney, K., Arnold, A.E. 2007. Biotic and abiotic factors influencing the distribution of the Huachuca springsnail (Pyrgulopsis thompsoni). Journal of Freshwater Ecology 22:213-218.

Turgeon, D.D., Quinn, J.F., Bogan, A.E., Coan, E.V., Hochberg, F.G., Lyons, W.G., Mikkelsen, P.M., Neves, R.J., Roper, C.F.E., Rosenberg, G., Roth, B., Scheltema, A., Thompson, F.G., Vecchione, M., Williams, J.D. 1998. Common and scientific names of aquatic invertebrates from the United States and Canada: Mollusks. Second edition. American Fisheries Society Special Publication 26.526 p.

USGS (United States Geological Survey). 2016. Nonindigenous aquatic species database, Gainesville, FL. Available from http://nas.er.usgs.gov (accessed 2/19/2016).

Varela-Romero, A., Myers, T.L., Sorensen, J., Abarca, F. 2013. Taxonomic status and phylogeny of the San Bernardino spring snail populations into the genus Pyrgulopsis in Sonora and Arizona. Biotecnia 15:45-50.

Vázquez, A.A., Cobian, D., Sánchez, J., Pointier, J.-P. 2012. First record of Littoridinops monroensis (Frauenfeld, 1863) (Gastropoda: Cochliopidae) in Cuba through a likely natural dispersal event. Molluscan Research 32:50-54.

Walker, B. 1908. Pomatiopsis robusta n. sp. Nautilus 21 [incorrectly listed as 22 on the first page]:97.

Walker, B. 1916. The Mollusca collected in northeastern Nevada by the WalkerNewcomb Expedition of the University of Michigan. Occasional Papers of the Museum of Zoology, University of Michigan 29:1-8.

Wilke, T., Davis, G.M., Falniowski, A., Giusti, F., Bodon, M., Szarowska, M. 2001. Molecular systematics of Hydrobiidae (Mollusca: Gastropoda: Rissooidea): testing monophyly and phylogenetic relationships. Proceedings of the Academy of Natural Sciences of Philadelphia 151:1-21.

Wilke, T., Haase, M., Hershler, R., Liu, H.-P., Misof, B., Ponder, W. 2013. Pushing short DNA fragments to the limit: phylogenetic relationships of 'hydrobioid' gastropods (Caenogastropoda: Rissooidea). Molecular Phylogenetics and Evolution 66:715-736. 


\section{Appendix}

Compilation of COI sequences. Amnicola: Liu et al. 2016; Colligyrus: Hershler et al. 2003a, Liu et al. 2015a; Lyogyrus: Liu et al. 2016; Eremopyrgus: Hershler et al. 1999; Ipnobius: Hershler et al. 1999; Littoridinops: Hershler et al. 2007a; Spurwinkia: Hershler et al. 2015a; Tryonia: Hershler et al. 1999a, Hershler et al. 1999b, Hershler et al. 2015a, Hershler et al. 2015b; Pyrgulopsis: Hershler et al. 2003a, Hershler et al. 2003b, Liu et al. 2003, Hershler and Liu 2004a, Hershler and Liu 2004b, Hurt 2004, Liu and Hershler 2005, Hershler et al. 2007b, Liu and Hershler 2007, Hershler and Liu 2008, Hershler et al. 2008, Hershler and Liu 2009, Hershler and Liu 2010, Hershler and Liu 2012a, Liu and Hershler 2012, Hershler et al. 2013, Liu et al. 2013b, Hershler et al. 2014b, Liu et al. 2015b, Hershler et al. 2016a, Hershler et al. 2016b; Fluminicola: Hershler et al. 2007c, Hershler and Liu 2012b, Liu et al. 2013a; Pristinicola: Hershler et al. 2003b; Taylorconcha: Hershler et al. 2006. 


\begin{tabular}{|c|c|c|c|c|c|c|c|c|}
\hline Species & $\begin{array}{l}\text { Published } \\
\text { Sample } \\
\text { Codes }\end{array}$ & $\begin{array}{l}\text { Accession } \\
\text { Numbers }\end{array}$ & $\begin{array}{c}\text { No. of } \\
\text { Specimens }(\mathrm{N})\end{array}$ & $\begin{array}{l}\text { Sequence } \\
\text { Variation } \\
\text { (\% pairwise } \\
\text { distance) }\end{array}$ & $\begin{array}{l}\text { Most Distant } \\
\text { Conspecific } \\
\text { Sequences (\%) }\end{array}$ & $\begin{array}{c}\text { Closest } \\
\text { Interspecific } \\
\text { Sequences (\%) }\end{array}$ & Collection Locality & Comments \\
\hline \multicolumn{9}{|c|}{ Amnicola } \\
\hline \multirow[t]{8}{*}{$\begin{array}{l}\text { Amnicola } \\
\text { limosa }\end{array}$} & AM5, AM11 & $\begin{array}{l}\text { KU991111, } \\
\text { KU991123 }\end{array}$ & 6 & $0 \%$ & $\begin{array}{c}0.5 \% \\
\text { with AM } 15\end{array}$ & & $\begin{array}{l}\text { Pattison Lake, east } \\
\text { side at Washington } \\
\text { Department of Fish } \\
\text { and Wildlife boat } \\
\text { ramp, Thurston } \\
\text { Cso., WA }\end{array}$ & \\
\hline & AM6 & $\begin{array}{l}\text { KU991118, } \\
\text { KU991119 }\end{array}$ & 4 & $0-0.20 \%$ & $\begin{array}{c}0.5 \% \\
\text { with AM } 15\end{array}$ & & $\begin{array}{l}\text { Bonaparte Lake, } \\
\text { south end at } \\
\text { campground, } \\
\text { Okanogan Co., WA }\end{array}$ & \\
\hline & AM7 & KU991120 & 4 & $0 \%$ & $\begin{array}{c}0.5 \% \\
\text { with AM } 15\end{array}$ & & $\begin{array}{l}\text { Curlew Lake at } \\
\text { state park west } \\
\text { of Hwy } 21, \text { Ferry } \\
\text { Co.,WA }\end{array}$ & \\
\hline & AM8 & KU991121 & 4 & $0 \%$ & $\begin{array}{c}0.5 \% \\
\text { with AM } 15\end{array}$ & & $\begin{array}{l}\text { Spectacle Lake, } \\
\text { south side, near } \\
\text { resort, Okanogan } \\
\text { Co., WA }\end{array}$ & \\
\hline & AM9 & KU991122 & 4 & $0 \%$ & $\begin{array}{c}0.5 \% \\
\text { with AM } 15\end{array}$ & & $\begin{array}{l}\text { Leader Lake, north } \\
\text { side near dam, } \\
\text { Okanogan Co., WA }\end{array}$ & \\
\hline & AM12 & KU991124 & 4 & $0-0.20 \%$ & $\begin{array}{c}0.6 \% \\
\text { with AM } 15\end{array}$ & & $\begin{array}{l}\text { McWenneger } \\
\text { Slough, south } \\
\text { side near Hwy 35, } \\
\text { Flathead Co., MT }\end{array}$ & \\
\hline & AM15 & $\begin{array}{l}\text { KU991126, } \\
\text { KU991127 }\end{array}$ & 4 & $0-0.50 \%$ & $\begin{array}{c}0.6 \% \\
\text { with } \mathrm{AM} 12\end{array}$ & & $\begin{array}{l}\text { Browns Lake, } \\
\text { cutoff pond along } \\
\text { northeast side, } \\
\text { Powell Co., MT }\end{array}$ & \\
\hline & AM16 & $\begin{array}{l}\text { KU9911128, } \\
\text { KU991129 }\end{array}$ & 4 & $0-0.30 \%$ & $\begin{array}{c}0.5 \% \text { with } \\
\text { AM12, AM15 }\end{array}$ & & $\begin{array}{l}\text { Georgetown } \\
\text { Lake, east side } \\
\text { north of Stuart } \\
\text { Campground, } \\
\text { Granite Co., MT }\end{array}$ & \\
\hline \multicolumn{9}{|c|}{ Colligyrus } \\
\hline \multirow[t]{3}{*}{$\begin{array}{l}\text { Colligyrus } \\
\text { convexus }\end{array}$} & $\mathrm{BL}$ & AY196166 & 1 & $0 \%$ & $0.3 \%$ with $\mathrm{MB}$ & $\begin{array}{l}\text { Colligyrus sp. } \\
\mathrm{KL} \text {, differ by } \\
3.9 \%\end{array}$ & $\begin{array}{l}\text { Baum Lake, Pit } \\
\text { River basin, Shasta } \\
\text { Co., CA }\end{array}$ & \\
\hline & TS & AY196167 & 1 & $0 \%$ & $0.5 \%$ with $\mathrm{MB}$ & $\begin{array}{l}\text { Colligyrus sp. } \\
\mathrm{KL} \text {, differ by } \\
4.0 \%\end{array}$ & $\begin{array}{l}\text { Fall River (spring } \\
\text { source), Pit River } \\
\text { basin, Shasta Co., } \\
\text { CA }\end{array}$ & \\
\hline & MB & $\begin{array}{l}\text { AY196168, } \\
\text { AY196169 }\end{array}$ & 2 & $0 \%$ & $0.5 \%$ with TS & $\begin{array}{c}\text { Colligyrus sp. } \\
\mathrm{KL} \text {, differ by } \\
3.8 \%\end{array}$ & $\begin{array}{l}\text { Burney Creek, Pit } \\
\text { River basin, Shasta } \\
\text { Co., CA }\end{array}$ & \\
\hline \multirow[t]{2}{*}{$\begin{array}{l}\text { Colligyrus } \\
\text { depressus }\end{array}$} & SRa & AY 196170 & 1 & $0 \%$ & $0 \%$ with SRb & $\begin{array}{l}\text { C. convexus, } \\
\text { differ by } \\
7.8-8.2 \% \text {, } \\
\text { Colligyrus sp. } \\
\text { KL, differ by } \\
7.8 \%\end{array}$ & $\begin{array}{l}\text { Second spring } \\
\text { south of Turner } \\
\text { Ranch, Silvies } \\
\text { River basin, Harney } \\
\text { Co., OR }\end{array}$ & \\
\hline & $\mathrm{SRb}$ & AY196171 & 1 & $0 \%$ & $0 \%$ with SRa & $\begin{array}{l}\text { C. convexus, } \\
\text { differ by } \\
7.8-8.2 \% \text {, } \\
\text { Colligyrus sp. } \\
\text { KL, differ by } \\
7.8 \%\end{array}$ & $\begin{array}{l}\text { Third spring south } \\
\text { of Turner Ranch, } \\
\text { Siivies River basin, } \\
\text { Harney Co., OR }\end{array}$ & \\
\hline
\end{tabular}




\begin{tabular}{|c|c|c|c|c|c|c|c|c|}
\hline Species & $\begin{array}{l}\text { Published } \\
\text { Sample } \\
\text { Codes }\end{array}$ & $\begin{array}{l}\text { Accession } \\
\text { Numbers }\end{array}$ & $\begin{array}{c}\text { No. of } \\
\text { Specimens (N) }\end{array}$ & $\begin{array}{c}\text { Sequence } \\
\text { Variation } \\
\text { (\% pairwise } \\
\text { distance) }\end{array}$ & $\begin{array}{l}\text { Most Distant } \\
\text { Conspecific } \\
\text { Sequences (\%) }\end{array}$ & $\begin{array}{c}\text { Closest } \\
\text { Interspecific } \\
\text { Sequences (\%) }\end{array}$ & Collection Locality & Comments \\
\hline \multirow[t]{11}{*}{$\begin{array}{l}\text { Colligyrus } \\
\text { greggi }\end{array}$} & COLl & KT248021 & 4 & $0 \%$ & $2.2 \%$ with SN & $\begin{array}{l}\text { C. depressus, } \\
\text { differ by } 9.3 \%\end{array}$ & $\begin{array}{l}\text { Small spring, } \\
\text { Brooks Meadow, } \\
\text { middle Columbia } \\
\text { River basin, Hood } \\
\text { River Co., OR }\end{array}$ & \\
\hline & COL2 & KT248022 & 4 & $0 \%$ & $2.5 \%$ with SN & $\begin{array}{l}\text { C. depressus, } \\
\text { differ by } 9.3 \%\end{array}$ & $\begin{array}{l}\text { Spring tributary, } \\
\text { Tony Creek, middle } \\
\text { Columbia River } \\
\text { basin, Hood River } \\
\text { Co., OR }\end{array}$ & \\
\hline & COL3 & KT248023 & 4 & $0 \%$ & $2.2 \%$ with SN & $\begin{array}{l}\text { C. depressus, } \\
\text { differ by } 9.3 \%\end{array}$ & $\begin{array}{l}\text { Bottle Prairie, } \\
\text { middle Columbia } \\
\text { River basin, Hood } \\
\text { River Co., OR }\end{array}$ & \\
\hline & $\mathrm{COL} 4$ & KT248024 & 4 & $0 \%$ & $2.2 \%$ with SN & $\begin{array}{l}\text { C. depressus, } \\
\text { differ by } 9.3 \%\end{array}$ & $\begin{array}{l}\text { Spring tributary, } \\
\text { Rarnsey Creek, } \\
\text { middle Columbia } \\
\text { River basin, Wasco } \\
\text { Co., OR }\end{array}$ & \\
\hline & COL5 & $\begin{array}{l}\text { KT248025 } \\
(N=3), \\
\text { KT248026 } \\
(N=1)\end{array}$ & 4 & $0-0.30 \%$ & $2.2 \%$ with SN & $\begin{array}{l}\text { C. depressus, } \\
\text { differ by } \\
9.2-9.3 \%\end{array}$ & $\begin{array}{l}\text { Spring tributary, } \\
\text { Clear Creek, } \\
\text { Deschutes River } \\
\text { basin, Wasco Co., } \\
\text { OR }\end{array}$ & \\
\hline & COL6 & $\begin{array}{c}\text { KT248027 } \\
(N=3),\end{array}$ & 4 & $0-0.20 \%$ & $2.7 \%$ with SN & $\begin{array}{l}\text { C. depressus, } \\
\text { differ by } \\
9.3-9.5 \%\end{array}$ & $\begin{array}{l}\text { Bear Creek, Hood } \\
\text { River Co., OR }\end{array}$ & \\
\hline & $\mathrm{CL}$ & AY196174 & 1 & $0 \%$ & $2.3 \%$ with SN & $\begin{array}{l}\text { C. depressus, } \\
\text { differ by } 9.2 \%\end{array}$ & $\begin{array}{l}\text { Oak Grove Fork } \\
\text { [Clackamas River], } \\
\text { Willamette River } \\
\text { basin, Clackamas } \\
\text { Co., OR }\end{array}$ & \\
\hline & SN & AY 196172 & 1 & $0 \%$ & $\begin{array}{l}2.7 \% \text { with } \\
\text { COL6 }\end{array}$ & $\begin{array}{l}\text { C. depressus, } \\
\text { differ by } 9.8 \%\end{array}$ & $\begin{array}{l}\text { Springs along } \\
\text { Cliff Creek, upper } \\
\text { Snake River basin, } \\
\text { Sublette Co., WY }\end{array}$ & \\
\hline & $\mathrm{BR}$ & AY196173 & 1 & $0 \%$ & $\begin{array}{l}2.3 \% \text { with } \\
\text { COL6 }\end{array}$ & $\begin{array}{l}\text { C. depressus, } \\
\text { differ by } 10.2 \%\end{array}$ & $\begin{array}{l}\text { Spring at } \\
\text { Saint Charles } \\
\text { Campground, Bear } \\
\text { Lake basin, Bear } \\
\text { Lake Co., ID }\end{array}$ & \\
\hline & AM17 & KT248030 & 2 & $0 \%$ & $\begin{array}{l}2.3 \% \text { with } \\
\text { COL6 }\end{array}$ & $\begin{array}{l}\text { C. depressus, } \\
\text { differ by } 10.3 \%\end{array}$ & $\begin{array}{l}\text { Spring at Porcupine } \\
\text { Campground, Bear } \\
\text { Lake basin, Bear } \\
\text { Lake Co, ID }\end{array}$ & \\
\hline & AM20 & KT248031 & 2 & $0 \%$ & $\begin{array}{l}2.3 \% \text { with } \\
\text { COL6 }\end{array}$ & $\begin{array}{l}\text { C. depressus, } \\
\text { differ by } 10.1 \%\end{array}$ & $\begin{array}{l}\text { Springs along } \\
\text { Trail Creek, upper } \\
\text { Snake River basin, } \\
\text { Caribou Co., ID }\end{array}$ & \\
\hline Colligyrus sp. & $\mathrm{KL}$ & AY196175 & 1 & $0 \%$ & & $\begin{array}{l}\text { C. convexus, } \\
\text { differ by } \\
3.8-4.0 \%\end{array}$ & $\begin{array}{l}\text { Link River, Klamath } \\
\text { River basin, } \\
\text { Klamath Co., OR }\end{array}$ & \\
\hline Colligyrus sp. & $\operatorname{COL} 7$ & KT248029 & 1 & $0 \%$ & & $\begin{array}{c}\text { C. greggi, differ } \\
\text { by } 10.3-11.2 \% \text {, } \\
\text { Colligyrus sp. } \\
\text { KL, differ by } \\
10.6 \%\end{array}$ & $\begin{array}{l}\text { Allison Springs, } \\
\text { Puget Sound } \\
\text { drainage, Thurston } \\
\text { Co., WA }\end{array}$ & \\
\hline
\end{tabular}




\begin{tabular}{|c|c|c|c|c|c|c|c|c|}
\hline Species & $\begin{array}{l}\text { Published } \\
\text { Sample } \\
\text { Codes }\end{array}$ & $\begin{array}{l}\text { Accession } \\
\text { Numbers }\end{array}$ & $\begin{array}{c}\text { No. of } \\
\text { Specimens (N) }\end{array}$ & $\begin{array}{l}\text { Sequence } \\
\text { Variation } \\
\text { (\% pairwise } \\
\text { distance) }\end{array}$ & $\begin{array}{l}\text { Most Distant } \\
\text { Conspecific } \\
\text { Sequences (\%) }\end{array}$ & $\begin{array}{c}\text { Closest } \\
\text { Interspecific } \\
\text { Sequences (\%) }\end{array}$ & Collection Locality & Comments \\
\hline \multirow[t]{2}{*}{ Lyogyrus sp. } & AM10 & KU991131 & 4 & $0 \%$ & $\begin{array}{c}0.5 \% \\
\text { with AM13 }\end{array}$ & & $\begin{array}{l}\text { Fish Lake, south } \\
\text { side at Cove } \\
\text { Resort, Chelan } \\
\text { Co., WA } \\
\end{array}$ & \\
\hline & AM13 & $\begin{array}{l}\text { KU991132, } \\
\text { KU991133, } \\
\text { KU991134 }\end{array}$ & 4 & $0-0.20 \%$ & $\begin{array}{c}0.8 \% \\
\text { with AM13 }\end{array}$ & & $\begin{array}{l}\text { Smith Lake, south } \\
\text { side at public } \\
\text { access boat ramp, } \\
\text { Flathead Co., MT }\end{array}$ & \\
\hline \multicolumn{9}{|c|}{ Eremopyrgus } \\
\hline $\begin{array}{l}\text { Eremopyrgus } \\
\text { eganensis }\end{array}$ & & AF129317 & 1 & $0.00 \%$ & & & $\begin{array}{l}\text { Spring, southeast } \\
\text { Steptoe Valley, } \\
\text { north of Ely, White } \\
\text { Pine Co., NV }\end{array}$ & $\begin{array}{l}\text { Tryonia sp. } \\
\text { in GenBank; } \\
\text { Tryonia n. sp. } \\
2 \text { in Hershler } \\
\text { et al. (1999b) }\end{array}$ \\
\hline \multicolumn{9}{|c|}{ Ipnobius } \\
\hline $\begin{array}{l}\text { Ipnobius } \\
\text { robustus }\end{array}$ & & AF061774 & 1 & & & & $\begin{array}{l}\text { Travertine Springs, } \\
\text { Death Valley, Inyo } \\
\text { Co., CA }\end{array}$ & $\begin{array}{l}\text { Tryonia } \\
\text { robusta in } \\
\text { GenBank }\end{array}$ \\
\hline \multicolumn{9}{|c|}{ Littoridinops } \\
\hline \multicolumn{9}{|c|}{ Spurwinkia } \\
\hline $\begin{array}{l}\text { Spurwinkia } \\
\text { salsa }\end{array}$ & & KP057916 & 4 & $0.00 \%$ & & & $\begin{array}{l}\text { Salt marsh, Eden } \\
\text { Landing, south } \\
\text { San Francisco Bay, } \\
\text { Alameda Co., CA }\end{array}$ & \\
\hline \multicolumn{9}{|c|}{ Tryonia } \\
\hline $\begin{array}{l}\text { Tryonia } \\
\text { angulata }\end{array}$ & & AF061764 & 1 & $0.00 \%$ & & $\begin{array}{l}\text { T. variegata SS, } \\
\text { differ by } 0.5 \%\end{array}$ & $\begin{array}{l}\text { Big Spring, Ash } \\
\text { Meadows, Nye } \\
\text { Co., NV }\end{array}$ & \\
\hline $\begin{array}{l}\text { Tryonia } \\
\text { clathrata }\end{array}$ & & AF061767 & 1 & $0.00 \%$ & & $\begin{array}{l}\text { T. infernalis, } \\
\text { differ by } \\
3.4-3.9 \%\end{array}$ & $\begin{array}{l}\text { Warm Spring, } \\
\text { Moapa Valley, Clark } \\
\text { Co., NV }\end{array}$ & \\
\hline $\begin{array}{l}\text { Tryonia } \\
\text { elata }\end{array}$ & & AF61766 & 1 & $0.00 \%$ & & $\begin{array}{c}T \text {. ericae, differ } \\
\text { by } 2.3 \%\end{array}$ & $\begin{array}{l}\text { Spring tributary to } \\
\text { Kings Pool, Point } \\
\text { of Rocks, Ash } \\
\text { Meadows, Nye } \\
\text { Co., NV }\end{array}$ & \\
\hline $\begin{array}{l}\text { Tryonia } \\
\text { ericae }\end{array}$ & & AF061768 & 1 & $0.00 \%$ & & $\begin{array}{l}\text { T. elata, differ } \\
\text { by } 2.3 \%\end{array}$ & $\begin{array}{l}\text { Spring north of } \\
\text { Collins Ranch, Ash } \\
\text { Meadows, Nye } \\
\text { Co., NV }\end{array}$ & \\
\hline
\end{tabular}




\begin{tabular}{|c|c|c|c|c|c|c|c|c|}
\hline Species & $\begin{array}{l}\text { Published } \\
\text { Sample } \\
\text { Codes }\end{array}$ & $\begin{array}{l}\text { Accession } \\
\text { Numbers }\end{array}$ & $\begin{array}{c}\text { No. of } \\
\text { Specimens }(\mathrm{N})\end{array}$ & $\begin{array}{l}\text { Sequence } \\
\text { Variation } \\
\text { (\% pairwise } \\
\text { distance) }\end{array}$ & $\begin{array}{l}\text { Most Distant } \\
\text { Conspecific } \\
\text { Sequences (\%) }\end{array}$ & $\begin{array}{c}\text { Closest } \\
\text { Interspecific } \\
\text { Sequences (\%) }\end{array}$ & Collection Locality & Comments \\
\hline $\begin{array}{l}\text { Tryonia } \\
\text { gilae }\end{array}$ & & AF129309 & 1 & $0.00 \%$ & & $\begin{array}{l}\text { T. angulata, } \\
\text { differ by } 4.2 \%\end{array}$ & $\begin{array}{l}\text { Tom Niece Spring, } \\
\text { Graham Co., AZ }\end{array}$ & \\
\hline \multirow[t]{2}{*}{$\begin{array}{l}\text { Tryonia } \\
\text { imitator }\end{array}$} & $\mathrm{M}, \mathrm{MO}$ & AF061770 & 1 & $0.00 \%$ & $\begin{array}{c}0.2 \% \\
\text { with S/PE }\end{array}$ & $\begin{array}{l}\text { T. salina, differ } \\
\text { by } 1.8 \%\end{array}$ & $\begin{array}{l}\text { Moro Cojo Slough, } \\
\text { Moss Landing, } \\
\text { Monterey Co., CA }\end{array}$ & \\
\hline & S, PE & AF061769 & 1 & $0.00 \%$ & $\begin{array}{c}0.2 \% \\
\text { with } \mathrm{M} / \mathrm{MO}\end{array}$ & $\begin{array}{l}T \text {. salina, differ } \\
\text { by } 1.6 \%\end{array}$ & $\begin{array}{l}\text { Los Penasquitos } \\
\text { Lagoon, San Diego } \\
\text { Co., CA }\end{array}$ & \\
\hline $\begin{array}{l}\text { Tryonia } \\
\text { infernalis }\end{array}$ & BP2 & $\begin{array}{c}\text { KP899916- } \\
18\end{array}$ & 6 & $0.0-1.1 \%$ & & $\begin{array}{l}\text { T. clathrata, } \\
\text { differ by } \\
3.4-3.9 \%\end{array}$ & $\begin{array}{l}\text { Blue Point Spring, } \\
\text { just below source, } \\
\text { Clark Co., NV }\end{array}$ & \\
\hline $\begin{array}{l}\text { Tryonia } \\
\text { margae }\end{array}$ & & AF061771 & 1 & $0.00 \%$ & & $\begin{array}{l}\text { T. monitorae, } \\
\text { differ by } 1.9 \%\end{array}$ & $\begin{array}{l}\text { Grapevine Springs } \\
\text { (upper warm } \\
\text { spring), Death } \\
\text { Valley, Inyo Co., CA }\end{array}$ & \\
\hline $\begin{array}{l}\text { Tryonia } \\
\text { monitorae }\end{array}$ & & AF129316 & 1 & $0.00 \%$ & & $\begin{array}{c}\text { T. margae, } \\
\text { differ by } 1.9 \%\end{array}$ & $\begin{array}{l}\text { Spring, Potts } \\
\text { Ranch, Monitor } \\
\text { Valley, Nye Co., NV }\end{array}$ & $\begin{array}{l}\text { Tryonia sp. } \\
\text { in GenBank, } \\
\text { Tryonia n. sp. } \\
1 \text { in Hershler } \\
\text { et al. (1999b) }\end{array}$ \\
\hline \multirow[t]{5}{*}{$\begin{array}{l}\text { Tryonia } \\
\text { porrecta }\end{array}$} & WH & $\begin{array}{l}\text { AF061773 } \\
(\mathrm{HI})\end{array}$ & 3 & $0.00 \%$ & $\begin{array}{l}2.1 \% \text { with SS } \\
(\mathrm{HX}) \text { and } \mathrm{HF} \\
(\mathrm{HVIII)}\end{array}$ & $\begin{array}{l}\text { T. imitator, } \\
\text { differ by } \\
4.9-5.0 \%\end{array}$ & $\begin{array}{l}\text { Whitmore Hot } \\
\text { Springs, Long } \\
\text { Valley, Mono Co., } \\
\text { CA }\end{array}$ & $\begin{array}{l}\text { Tryonia protea } \\
\text { in GenBank }\end{array}$ \\
\hline & $\mathrm{HC}$ & $\begin{array}{l}\text { AY803024 } \\
(H I)\end{array}$ & 3 & $0.00 \%$ & $\begin{array}{c}2.1 \% \text { with SS } \\
(\mathrm{HX}) \text { and } \mathrm{HF} \\
(\mathrm{HVIIII})\end{array}$ & $\begin{array}{l}\text { T. imitator, } \\
\text { differ by } \\
4.9-5.0 \%\end{array}$ & $\begin{array}{l}\text { Hot Creek, Long } \\
\text { Valley, Owens } \\
\text { River basin, Mono } \\
\text { Co., CA }\end{array}$ & \\
\hline & $O A$ & $\begin{array}{l}\text { AF061772 } \\
(\mathrm{HI})\end{array}$ & 1 & $0.00 \%$ & $\begin{array}{c}2.1 \% \text { with SS } \\
(\mathrm{HX}) \text { and } \mathrm{HF} \\
(\mathrm{HVIIII)}\end{array}$ & $\begin{array}{l}\text { T. imitator, } \\
\text { differ by } \\
4.8-4.9 \%\end{array}$ & $\begin{array}{l}\text { Oasis Spring, } \\
\text { Salt Creek, Salton } \\
\text { Trough, Riverside } \\
\text { Co., CA }\end{array}$ & $\begin{array}{l}\text { Tryonia protea } \\
\text { in GenBank }\end{array}$ \\
\hline & $\mathrm{HU}$ & $\begin{array}{l}\text { AY803025 } \\
(\mathrm{HI})\end{array}$ & 4 & $0.00 \%$ & $\begin{array}{c}2.1 \% \text { with SS } \\
(\mathrm{HX}) \text { and HF } \\
(\mathrm{HVIII})\end{array}$ & $\begin{array}{l}\text { T. imitator, } \\
\text { differ by } \\
4.9-5.0 \%\end{array}$ & $\begin{array}{l}\text { Hunters Spring, } \\
\text { Salton Sea basin, } \\
\text { Riverside Co., CA }\end{array}$ & \\
\hline & SS & $\begin{array}{c}\text { AY803023 } \\
(H \mathrm{HI}) \\
\text { AY803029 } \\
(\mathrm{HIII}), \\
\text { AY803030 } \\
(\mathrm{HX}), \\
\text { AY803031 } \\
(\mathrm{HIX})\end{array}$ & 6 & $0.0-2.5 \%$ & $\begin{array}{l}\text { HI: } 2.1 \% \text { with } \\
\text { SS (HX) and } \\
\text { HF (HVIII); } \\
\text { HIII: } 2.5 \% \text { with } \\
\text { SS (HX), HF } \\
\text { (HVIII), Misc4A, } \\
\text { and Misc5A; } \\
\text { HX: } 2.6 \% \text { with } \\
\text { HS (HV); } \\
\text { HIX: } 2.5 \% \text { with } \\
\text { HS (HV) }\end{array}$ & $\begin{array}{l}\text { T. imitator, } \\
\text { differ by } \\
4.8-5.1 \%\end{array}$ & $\begin{array}{l}\text { South Springs, } \\
\text { Fish Springs Flat, } \\
\text { Bonneville basin, } \\
\text { Juab Co., UT }\end{array}$ & \\
\hline
\end{tabular}




\begin{tabular}{|c|c|c|c|c|c|c|c|c|}
\hline Species & $\begin{array}{l}\text { Published } \\
\text { Sample } \\
\text { Codes }\end{array}$ & $\begin{array}{l}\text { Accession } \\
\text { Numbers }\end{array}$ & $\begin{array}{c}\text { No. of } \\
\text { Specimens (N) }\end{array}$ & $\begin{array}{l}\text { Sequence } \\
\text { Variation } \\
\text { (\% pairwise } \\
\text { distance) }\end{array}$ & $\begin{array}{l}\text { Most Distant } \\
\text { Conspecific } \\
\text { Sequences (\%) }\end{array}$ & $\begin{array}{c}\text { Closest } \\
\text { Interspecific } \\
\text { Sequences (\%) }\end{array}$ & Collection Locality & Comments \\
\hline \multirow[t]{9}{*}{$\begin{array}{c}\text { Tryonia } \\
\text { porrecta } \\
\text { (continued) }\end{array}$} & HS & $\begin{array}{c}\text { AF129312 } \\
\text { (HIV), } \\
\text { AY803027 } \\
\text { (HII), } \\
\text { AY803028 } \\
\text { (HV), } \\
\text { AY803032 } \\
\text { (HVI) }\end{array}$ & 4 & $0.8-2.3 \%$ & $\begin{array}{c}\text { HIV: } 2.4 \% \text { with } \\
\text { SS (HX), HF } \\
\text { (HVIII), Misc4A, } \\
\text { and Misc5A; } \\
\text { HII: } 2.5 \% \text { with } \\
\text { SS (HX), HF } \\
\text { (HVIII), Misc4A, } \\
\text { and Misc5A; } \\
\text { HV: } 2.6 \% \text { with } \\
\text { SS (HX), HF } \\
\text { (HVIII), Misc4A, } \\
\text { and Misc5A; } \\
\text { HVI: } 2.3 \% \text { with } \\
\text { HS (HV) }\end{array}$ & $\begin{array}{l}\text { T. imitator, } \\
\text { differ by } \\
4.6-5.1 \%\end{array}$ & $\begin{array}{l}\text { Horseshoe Springs, } \\
\text { Skull Valley, Tooele } \\
\text { Co., UT }\end{array}$ & $\begin{array}{l}\text { Tryonia protea } \\
\text { in GenBank, } \\
\text { collection } \\
\text { locality given } \\
\text { as Warm } \\
\text { Spring in } \\
\text { GenBank }\end{array}$ \\
\hline & WS & $\begin{array}{c}A F 129313 \\
(H I)\end{array}$ & 2 & $0.00 \%$ & $\begin{array}{l}2.1 \% \text { with SS } \\
(\mathrm{HX}) \text { and } \mathrm{HF} \\
\text { (HVIII) }\end{array}$ & $\begin{array}{l}\text { T. imitator, } \\
\text { differ by } \\
4.9-5.1 \%\end{array}$ & $\begin{array}{l}\text { Warm Springs, } \\
\text { Tooele Valley, } \\
\text { Tooele Co., UT }\end{array}$ & $\begin{array}{l}\text { Tryonia protea } \\
\text { in GenBank }\end{array}$ \\
\hline & $\mathrm{BL}$ & $\begin{array}{c}\text { AFI29314 } \\
(H I)\end{array}$ & 2 & $0.00 \%$ & $\begin{array}{l}2.1 \% \text { with SS } \\
(\mathrm{HX}) \text { and } \mathrm{HF} \\
(\mathrm{HVIII})\end{array}$ & $\begin{array}{l}\text { T. imitator, } \\
\text { differ by } \\
4.7-4.9 \%\end{array}$ & $\begin{array}{l}\text { Spring, Blue Lake, } \\
\text { Great Salt Lake } \\
\text { Desert, Tooele } \\
\text { Co., UT }\end{array}$ & $\begin{array}{l}\text { Tryonia protea } \\
\text { in GenBank }\end{array}$ \\
\hline & $\mathrm{HF}$ & $\begin{array}{l}\text { AY803033 } \\
\text { (HVIII), } \\
\text { AY803034 } \\
\text { (HVII) }\end{array}$ & 5 & $0.0-0.2 \%$ & $\begin{array}{c}2.5-2.6 \% \text { with } \\
\text { HS (HV) }\end{array}$ & $\begin{array}{l}\text { T. imitator, } \\
\text { differ by } \\
4.9-5.3 \%\end{array}$ & $\begin{array}{l}\text { Spring, Hualapai } \\
\text { Flat, Lahontan } \\
\text { basin, Washoe } \\
\text { Co., NV }\end{array}$ & \\
\hline & ED & $\begin{array}{l}\text { AY803026 } \\
(H I)\end{array}$ & 3 & $0.00 \%$ & $\begin{array}{l}2.1 \% \text { with SS } \\
(\mathrm{HX}) \text { and } \mathrm{HF} \\
(\mathrm{HVIIII})\end{array}$ & $\begin{array}{l}\text { T. imitator, } \\
\text { differ by } \\
4.9-5.0 \%\end{array}$ & $\begin{array}{l}\text { Spring at El Doctor, } \\
\text { Colorado River } \\
\text { basin, Sonora, } \\
\text { Mexico }\end{array}$ & \\
\hline & FS & $\begin{array}{c}\text { AF129311 } \\
(H I)\end{array}$ & 1 & $0.00 \%$ & $\begin{array}{l}2.1 \% \text { with SS } \\
(H X) \text { and } H F \\
(H V I I I)\end{array}$ & $\begin{array}{l}\text { T. imitator, } \\
\text { differ by } \\
4.9-5.0 \%\end{array}$ & $\begin{array}{l}\text { Spring, south end } \\
\text { of Fish Springs } \\
\text { National Wildlife } \\
\text { Refuge, Juab Co., } \\
\text { UT }\end{array}$ & $\begin{array}{l}\text { Tryonia protea } \\
\text { in GenBank }\end{array}$ \\
\hline & & $\begin{array}{l}\text { KP057915 } \\
\text { (HI) }\end{array}$ & 1 & $0.00 \%$ & $\begin{array}{c}2.1 \% \text { with SS } \\
(H X) \text { and } H F \\
(H V I I I)\end{array}$ & $\begin{array}{l}\text { T. imitator, } \\
\text { differ by } \\
4.9-5.0 \%\end{array}$ & $\begin{array}{l}\text { Garden Lakes, } \\
\text { Avondale, Maricopa } \\
\text { Co., AZ }\end{array}$ & \\
\hline & Misc4A & EF490563 & 1 & $0.00 \%$ & $\begin{array}{c}2.6 \% \text { with HS } \\
(\mathrm{HV})\end{array}$ & $\begin{array}{l}\text { T. imitator, } \\
\text { differ by } \\
4.6-5.0 \%\end{array}$ & $\begin{array}{l}\text { Restored tidal } \\
\text { marsh on north } \\
\text { side of Waterfront } \\
\text { Road, Point Edith } \\
\text { Wildlife Area, } \\
\text { Contra Costa Co., } \\
\text { CA }\end{array}$ & \\
\hline & Misc5A & EF490564 & 1 & $0.00 \%$ & $\begin{array}{c}2.6 \% \text { with HS } \\
(\mathrm{HV})\end{array}$ & $\begin{array}{l}\text { T. imitator, } \\
\text { differ by } \\
4.6-5.0 \%\end{array}$ & $\begin{array}{l}\text { Restored tidal } \\
\text { marsh, southeast } \\
\text { of Point Edith } \\
\text { Wildlife Area, } \\
\text { Contra Costa Co., } \\
\text { CA }\end{array}$ & \\
\hline $\begin{array}{c}\text { Tryonia } \\
\text { quitobaquitae }\end{array}$ & & AF129315 & 1 & $0.00 \%$ & & $\begin{array}{c}\text { T. angulata, } \\
\text { differ by } 5.0 \%\end{array}$ & $\begin{array}{l}\text { Quitobaquito } \\
\text { Springs, Pima } \\
\text { Co., AZ }\end{array}$ & \\
\hline $\begin{array}{l}\text { Tryonia } \\
\text { rowlandsi }\end{array}$ & & AF061775 & 1 & $0.00 \%$ & & $\begin{array}{c}\text { T. angulata, } \\
\text { differ by } 3.8 \%\end{array}$ & $\begin{array}{l}\text { Grapevine Springs } \\
\text { (lower warm } \\
\text { spring), Death } \\
\text { Valley, Inyo Co., CA }\end{array}$ & \\
\hline
\end{tabular}




\begin{tabular}{|c|c|c|c|c|c|c|c|c|}
\hline Species & $\begin{array}{l}\text { Published } \\
\text { Sample } \\
\text { Codes }\end{array}$ & $\begin{array}{l}\text { Accession } \\
\text { Numbers }\end{array}$ & $\begin{array}{c}\text { No. of } \\
\text { Specimens }(\mathrm{N})\end{array}$ & $\begin{array}{l}\text { Sequence } \\
\text { Variation } \\
\text { (\% pairwise } \\
\text { distance) }\end{array}$ & $\begin{array}{l}\text { Most Distant } \\
\text { Conspecific } \\
\text { Sequences (\%) }\end{array}$ & $\begin{array}{c}\text { Closest } \\
\text { Interspecific } \\
\text { Sequences (\%) }\end{array}$ & Collection Locality & Comments \\
\hline $\begin{array}{l}\text { Tryonia } \\
\text { salina }\end{array}$ & & AF061776 & 1 & $0.00 \%$ & & $\begin{array}{l}\text { T. imitator, } \\
\text { differ by } \\
1.6-1.8 \%\end{array}$ & $\begin{array}{l}\text { Spring, Cottonball } \\
\text { Marsh, Death } \\
\text { Valley, Inyo Co., CA }\end{array}$ & \\
\hline \multirow[t]{2}{*}{$\begin{array}{c}\text { Tryonia } \\
\text { variegata }\end{array}$} & DV, DH & AF061778 & 1 & $0.00 \%$ & & $\begin{array}{c}\text { T. ericae, differ } \\
\text { by } 2.9 \%\end{array}$ & $\begin{array}{l}\text { Devils Hole, Ash } \\
\text { Meadows, Nye } \\
\text { Co., NV }\end{array}$ & \\
\hline & SA, SS & AF061777 & 1 & $0.00 \%$ & & $\begin{array}{l}\text { T. angulata, } \\
\text { differ by } 0.5 \%\end{array}$ & $\begin{array}{l}\text { Saratoga Spring, } \\
\text { Amargosa River } \\
\text { drainage, San } \\
\text { Bernardino Co., CA }\end{array}$ & \\
\hline \multicolumn{9}{|c|}{ Pyrgulopsis } \\
\hline \multirow[t]{3}{*}{$\begin{array}{l}\text { Pyrgulopsis } \\
\text { amargosae }\end{array}$} & P. amer 2 & AY367479 & 1 & $0.00 \%$ & $\begin{array}{l}\text { 7.3-7.4\% with } P \text {. } \\
\text { "amargosae" (2) }\end{array}$ & $\begin{array}{c}\text { P. anatina, } \\
\text { differ by } 4.8 \% \text {, } \\
\text { P. bacchus, } \\
\text { differ by } \\
4.0-5.1 \% \text {, } \\
\text { P. perforata, } \\
\text { differ by } \\
4.5-4.8 \%\end{array}$ & $\begin{array}{l}\text { Saratoga Spring, } \\
\text { Death Valley, San } \\
\text { Bernardino Co., CA }\end{array}$ & \\
\hline & $\begin{array}{c}P . \\
\text { "amargosae" } \\
\text { (1) }\end{array}$ & DQ364002 & 1 & $0.00 \%$ & $\begin{array}{l}6.9 \% \text { with } P . \\
\text { amargosae }\end{array}$ & $\begin{array}{c}\text { P. bifurcata, } \\
\text { differ by } 4.9 \% \text {, } \\
\text { P. intermedia, } \\
\text { differ by } \\
4.8-5.4 \% \text {, } \\
\text { P. thompsoni, } \\
\text { differ by } \\
4.8-5.9 \%\end{array}$ & $\begin{array}{l}\text { Third spring along } \\
\text { trail (from north), } \\
\text { Amargosa Canyon, } \\
\text { Inyo Co., CA }\end{array}$ & $\begin{array}{l}\text { Pyrgulopsis sp. } \\
1 \text { HPL-2003 in } \\
\text { GenBank }\end{array}$ \\
\hline & $\begin{array}{c}P . \\
\text { "amargosae" } \\
\text { (2) }\end{array}$ & $\begin{array}{l}\text { AF520924, } \\
\text { KF559193 }\end{array}$ & 2 & $1.30 \%$ & $\begin{array}{l}\text { 7.3-7.4\% with } \\
\text { P. amargosae }\end{array}$ & $\begin{array}{l}\text { P. intermedia, } \\
\text { differ by } \\
5.1-5.8 \% \text {, } \\
\text { P. micrococcus, } \\
\text { differ by } \\
5.3-5.6 \% \text {, } \\
\text { P. milleri, differ } \\
\text { by } 5.4-5.7 \% \text {, } \\
\text { P. thompsoni, } \\
\text { differ by } \\
5.0-6.3 \%\end{array}$ & $\begin{array}{l}\text { Spring, Amargosa } \\
\text { Canyon, Inyo, Co., } \\
\text { CA }\end{array}$ & \\
\hline $\begin{array}{l}\text { Pyrgulopsis } \\
\text { anatina }\end{array}$ & P58 & AY627926 & 1 & $0.00 \%$ & & $\begin{array}{l}\text { P. bifurcata, } \\
\text { differ by } 4.5 \% \text {, } \\
\text { P. torrida, differ } \\
\text { by } 4.5 \%\end{array}$ & $\begin{array}{l}\text { Spring southeast of } \\
\text { Old Collins Spring, } \\
\text { Railroad Valley, Nye } \\
\text { Co., NV }\end{array}$ & \\
\hline $\begin{array}{l}\text { Pyrgulopsis } \\
\text { anguina }\end{array}$ & P94B & EU700466 & 1 & $0.00 \%$ & & $\begin{array}{c}\text { P. kolobensis, } \\
\text { differ by } \\
3.2-4.4 \% \text {, } \\
\text { P. marcida, } \\
\text { differ by } 3.4 \% \text {, } \\
\text { P. nonaria, } \\
\text { differ by } 3.6 \% \text {, } \\
\text { P. variegata, } \\
\text { differ by } 3.6 \%\end{array}$ & $\begin{array}{l}\text { Big Springs, Snake } \\
\text { Valley, White Pine } \\
\text { Co., NV }\end{array}$ & \\
\hline \multirow[t]{2}{*}{$\begin{array}{l}\text { Pyrgulopsis } \\
\text { archimedis }\end{array}$} & $\mathrm{AH}$ & AY 197583 & 1 & $0.00 \%$ & $\begin{array}{l}0.2-0.4 \% \text { with } \\
\text { UK/P50 }\end{array}$ & $\begin{array}{l}\text { P. rupinicola, } \\
\text { differ by } \\
2.7-2.9 \%, \\
\text { P. sp. A, differ } \\
\text { by } 2.4-2.9 \%\end{array}$ & $\begin{array}{l}\text { Big Lake Springs, } \\
\text { Pit River basin, } \\
\text { Shasta Co., CA }\end{array}$ & \\
\hline & $\mathrm{BL}, \mathrm{D} 8 \mathrm{~B}$ & AY197579 & 1 & $0.00 \%$ & $\begin{array}{l}0.2-0.4 \% \text { with } \\
\text { UK/P50 }\end{array}$ & $\begin{array}{l}\text { P. rupinicola, } \\
\text { differ by } \\
2.7-2.9 \% \text {, } \\
\text { P. sp. A, differ } \\
\text { by } 2.4-2.9 \%\end{array}$ & $\begin{array}{l}\text { Baum Lake, Pit } \\
\text { River basin, Shasta } \\
\text { Co., CA }\end{array}$ & \\
\hline
\end{tabular}




\begin{tabular}{|c|c|c|c|c|c|c|c|c|}
\hline Species & $\begin{array}{l}\text { Published } \\
\text { Sample } \\
\text { Codes }\end{array}$ & $\begin{array}{l}\text { Accession } \\
\text { Numbers }\end{array}$ & $\begin{array}{c}\text { No. of } \\
\text { Specimens (N) }\end{array}$ & $\begin{array}{l}\text { Sequence } \\
\text { Variation } \\
\text { (\% pairwise } \\
\text { distance) } \\
\end{array}$ & $\begin{array}{l}\text { Most Distant } \\
\text { Conspecific } \\
\text { Sequences (\%) }\end{array}$ & $\begin{array}{c}\text { Closest } \\
\text { Interspecific } \\
\text { Sequences (\%) }\end{array}$ & Collection Locality & Comments \\
\hline \multirow[t]{8}{*}{$\begin{array}{l}\text { Pyrgulopsis } \\
\text { archimedis } \\
\text { (continued) }\end{array}$} & $\begin{array}{c}\text { FR_a/D1A, } \\
\text { D1D }\end{array}$ & $\begin{array}{l}\text { AY197577 } \\
\text { (FR_a/D1A), } \\
\text { AY426357 } \\
\text { (D1D) }\end{array}$ & 2 & $0.00 \%$ & $\begin{array}{l}0.2-0.4 \% \text { with } \\
\text { UK/P50 }\end{array}$ & $\begin{array}{c}\text { P. rupinicola, } \\
\text { differ by } \\
2.7-2.9 \% \text {, } \\
\text { P. sp. A, differ } \\
\text { by } 2.4-2.9 \%\end{array}$ & $\begin{array}{l}\text { Fall River (CalTrout } \\
\text { Access), Pit River } \\
\text { basin, Shasta Co., } \\
\text { CA }\end{array}$ & $\begin{array}{l}\text { AY426357/ } \\
\text { D1D listed as } \\
\text { P. intermedia } \\
\text { in GenBank }\end{array}$ \\
\hline & FR_b & AY197581 & 1 & $0.00 \%$ & $\begin{array}{c}0.2-0.4 \% \text { with } \\
\text { UK/P50 }\end{array}$ & $\begin{array}{l}\text { P. rupinicola, } \\
\text { differ by } \\
2.7-2.9 \% \text {, } \\
\text { P. sp. A, differ } \\
\text { by } 2.4-2.9 \%\end{array}$ & $\begin{array}{l}\text { Spring source, } \\
\text { Fall River, Pit River } \\
\text { basin, Shasta Co., } \\
\text { CA }\end{array}$ & \\
\hline & JS & AY197578 & 1 & $0.00 \%$ & $\begin{array}{c}0.3-0.6 \% \text { with } \\
\text { UK/P50 }\end{array}$ & $\begin{array}{l}\text { P. rupinicola, } \\
\text { differ by } \\
2.9-3.1 \% \text {, } \\
\text { P. sp. A, differ } \\
\text { by } 2.6-3.1 \%\end{array}$ & $\begin{array}{l}\text { Ja She Creek, Pit } \\
\text { River basin, Shasta } \\
\text { Co., CA }\end{array}$ & \\
\hline & $\begin{array}{c}\mathrm{KL} \text { Ka/D31A, } \\
\mathrm{D} 31 \mathrm{~B}\end{array}$ & $\begin{array}{c}\text { AY197586 } \\
\text { (KL_a/D31A), } \\
\text { AY426356 } \\
\text { (D31B) }\end{array}$ & 2 & $0.00 \%$ & $\begin{array}{c}0.3-0.6 \% \text { with } \\
\text { UK/P50 }\end{array}$ & $\begin{array}{l}\text { P. rupinicola, } \\
\text { differ by } \\
2.6-2.7 \% \text {, } \\
\text { P. sp. A, differ } \\
\text { by } 2.4-2.9 \%\end{array}$ & $\begin{array}{l}\text { Fifth Link River } \\
\text { spring, Klamath } \\
\text { basin, Klamath } \\
\text { Co., OR }\end{array}$ & $\begin{array}{l}\text { AY426356/ } \\
\text { D31B } \\
\text { listed as } P \text {. } \\
\text { intermedia in } \\
\text { GenBank }\end{array}$ \\
\hline & L01, LO2 & $\begin{array}{l}\text { AY197584 } \\
\text { (LO1) } \\
\text { AY197585 } \\
\text { (LO2) }\end{array}$ & 2 & $0.00 \%$ & $\begin{array}{l}0.3 \% \text { with JS, } \\
\text { KL_a/D31 }\end{array}$ & $\begin{array}{l}\text { P. rupinicola, } \\
\text { differ by } \\
2.9-3.1 \% \text {, } \\
\text { P. sp. A, differ } \\
\text { by } 2.6-2.9 \%\end{array}$ & $\begin{array}{l}\text { Lost River near } \\
\text { Horsefly Irrigation } \\
\text { District, Klamath } \\
\text { basin, Klamath } \\
\text { Co., OR }\end{array}$ & \\
\hline & PR/D7A, D7C & $\begin{array}{l}\text { AY197580 } \\
\text { (PR/D7A), } \\
\text { AY426358 } \\
\text { (D7C) }\end{array}$ & 2 & $0.00 \%$ & $\begin{array}{l}0.2-0.4 \% \text { with } \\
\text { UK/P50 }\end{array}$ & $\begin{array}{l}\text { P. rupinicola, } \\
\text { differ by } \\
2.7-2.9 \% \text {, } \\
\text { P. sp. A, differ } \\
\text { by } 2.4-2.9 \%\end{array}$ & $\begin{array}{l}\text { Pit River at } \\
\text { confluence with } \\
\text { Hat Creek, } \\
\text { Shasta Co., CA }\end{array}$ & $\begin{array}{l}\text { AY426358/ } \\
\text { D7C listed as } \\
\text { P. intermedia } \\
\text { in GenBank }\end{array}$ \\
\hline & $\mathrm{TH}$ & AY197582 & 1 & $0.00 \%$ & $\begin{array}{c}0.2-0.4 \% \text { with } \\
\text { UK/P50 }\end{array}$ & $\begin{array}{l}\text { P. rupinicola, } \\
\text { differ by } \\
2.7-2.9 \% \text {, } \\
\text { P. sp. A, differ } \\
\text { by } 2.4-2.9 \%\end{array}$ & $\begin{array}{l}\text { Three unnamed } \\
\text { springs, Pit River } \\
\text { basin, Shasta Co., } \\
\text { CA }\end{array}$ & \\
\hline & $\begin{array}{l}\text { UK/P50A, } \\
\text { P50C }\end{array}$ & $\begin{array}{l}\text { AF520950 } \\
\text { (UK/P50A), } \\
\text { AY426355 } \\
\text { (P50C) }\end{array}$ & 2 & $0.20 \%$ & $\begin{array}{c}0.3-0.6 \% \\
\text { with JS, } \\
\text { KL_a/D31 }\end{array}$ & $\begin{array}{l}\text { P. rupinicola, } \\
\text { differ by } \\
2.9-3.2 \% \text {, } \\
\text { P. sp. A, differ } \\
\text { by } 2.6-3.6 \%\end{array}$ & $\begin{array}{l}\text { Upper Klamath } \\
\text { Lake at Hagelstein } \\
\text { Park outlet, } \\
\text { Klamath Co., OR }\end{array}$ & \\
\hline \multirow[t]{2}{*}{$\begin{array}{l}\text { Pyrgulopsis } \\
\text { arizonae }\end{array}$} & P148 & AY 627948 & 1 & $0.00 \%$ & $\begin{array}{c}1.5-1.7 \% \text { with } \\
\text { Psan6-9 }\end{array}$ & $\begin{array}{c}\text { P. coloradensis, } \\
\text { differ by } 5.0 \% \text {, } \\
\text { P. sanchezi, } \\
\text { differ by } \\
4.1-5.2 \%\end{array}$ & $\begin{array}{l}\text { Medicine Spring, } \\
\text { Bylas, Gila River } \\
\text { basin, Graham Co., } \\
\text { AZ }\end{array}$ & \\
\hline & $\begin{array}{l}\text { Psan1, } \\
\text { Psan2, } \\
\text { Psan3, } \\
\text { Psan4, } \\
\text { Psan5 }\end{array}$ & $\begin{array}{c}\text { AY485561 } \\
\text { (Psan1, N=26), } \\
\text { AY485562 } \\
\text { (Psan2, } N=1 \text { ), } \\
\text { AY485563 } \\
\text { (Psan3, } N=1 \text { ), } \\
\text { AY485564 } \\
\text { (Psan4, } N=1 \text { ), } \\
\text { AY485565 } \\
\text { (Psan5, } N=1 \text { ) }\end{array}$ & 30 & $0.2-0.6 \%$ & $\begin{array}{l}1.1-1.5 \% \text { with } \\
\text { Psan6-9 }\end{array}$ & $\begin{array}{c}\text { P. coloradensis, } \\
\text { differ by } \\
5.6-5.9 \% \\
\text { P. sanchezi, } \\
\text { differ by } \\
4.6-5.9 \%\end{array}$ & Cold & $\begin{array}{l}\text { Hurt (2004), } \\
\text { listed as P. } \\
\text { sancarlosensis } \\
\text { in GenBank }\end{array}$ \\
\hline
\end{tabular}




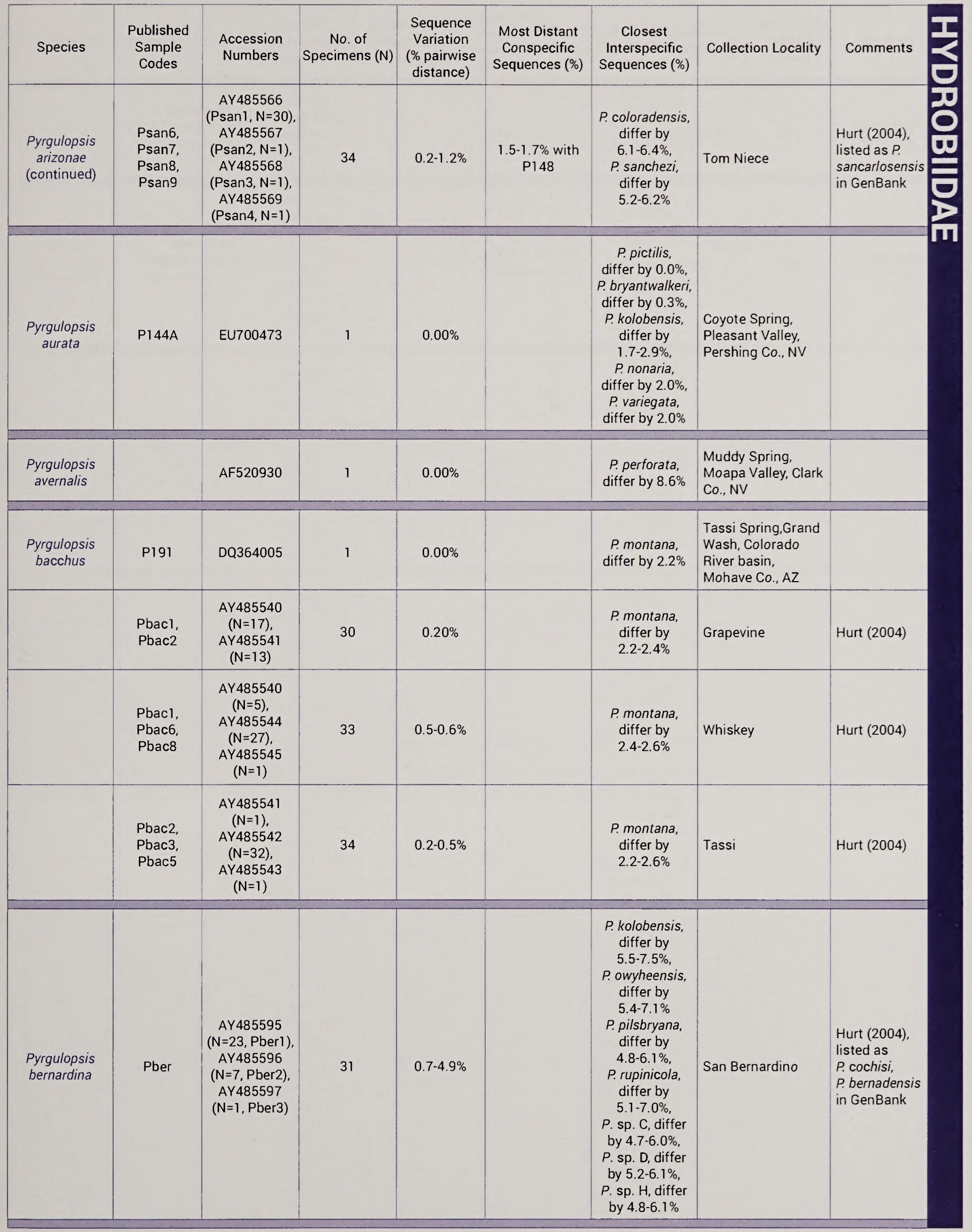




\begin{tabular}{|c|c|c|c|c|c|c|c|c|}
\hline Species & $\begin{array}{l}\text { Published } \\
\text { Sample } \\
\text { Codes }\end{array}$ & $\begin{array}{l}\text { Accession } \\
\text { Numbers }\end{array}$ & $\begin{array}{c}\text { No. of } \\
\text { Specimens (N) }\end{array}$ & $\begin{array}{c}\text { Sequence } \\
\text { Variation } \\
\text { (\% pairwise } \\
\text { distance) }\end{array}$ & $\begin{array}{l}\text { Most Distant } \\
\text { Conspecific } \\
\text { Sequences (\%) }\end{array}$ & $\begin{array}{c}\text { Closest } \\
\text { Interspecific } \\
\text { Sequences (\%) }\end{array}$ & Collection Locality & Comments \\
\hline $\begin{array}{l}\text { Pyrgulopsis } \\
\text { bifurcata }\end{array}$ & P56 & AY 627925 & 1 & $0.00 \%$ & & $\begin{array}{c}\text { P. pellita, } \\
\text { differ by } 3.3 \% \text {, } \\
\text { P. perforata, } \\
\text { differ by } \\
3.3-3.5 \%\end{array}$ & $\begin{array}{l}\text { Springs west of } \\
\text { Carico Lake, Carico } \\
\text { Lake basin, Lander } \\
\text { Co., NV }\end{array}$ & \\
\hline $\begin{array}{l}\text { Pyrgulopsis } \\
\text { breviloba }\end{array}$ & P63 & AY627928 & 1 & $0.00 \%$ & & $\begin{array}{c}\text { P. lata, differ } \\
\text { by } 0.5 \% \text {, } \\
\text { P. kolobensis, } \\
\text { differ by } \\
3.4-4.8 \% \text {, } \\
P . \text { marcida, } \\
\text { differ by } 3.7 \% \text {, } \\
P . \text { nonaria, } \\
\text { differ by } 3.7 \%\end{array}$ & $\begin{array}{l}\text { Flag Springs } \\
\text { (middle), White } \\
\text { River Valley, Nye } \\
\text { Co., NV }\end{array}$ & \\
\hline $\begin{array}{c}\text { Pyrgulopsis } \\
\text { bruesi }\end{array}$ & & AF520926 & 1 & $0.00 \%$ & & $\begin{array}{c}\text { P. dixensis, } \\
\text { differ by } 0.3 \% \text {, } \\
\text { P. conica, } \\
\text { differ by } 3.4 \% \text {, } \\
\text { P. glandulosa, } \\
\text { differ by } \\
3.3-3.8 \% \text {, } \\
\text { P. montana, } \\
\text { differ by } 3.3 \% \text {, } \\
\text { P. thompsoni, } \\
\text { differ by } \\
3.2-4.4 \%\end{array}$ & $\begin{array}{l}\text { Fly Geyser, Black } \\
\text { Rock Desert, } \\
\text { Washoe Co., NV }\end{array}$ & \\
\hline \multirow[t]{2}{*}{$\begin{array}{l}\text { Pyrgulopsis } \\
\text { bruneauensis }\end{array}$} & bruneauensis & AF520941 & 1 & $0.00 \%$ & $1.8 \%$ with $\mathrm{Pbr} 1$ & $\begin{array}{c}\text { P. kolobensis, } \\
\text { differ by } \\
5.3-6.1 \% \text {, } \\
\text { P. marcida, } \\
\text { differ by } 5.3 \% \text {, } \\
\text { P. pilsbryana, } \\
\text { differ by } 5.3 \% \text {, } \\
\text { P. variegata, } \\
\text { differ by } 5.3 \% \text {, } \\
P . \text { sp. } \mathrm{B}, \\
\text { differ by } 5.3 \% \text {, } \\
\text { P. sp. C, differ } \\
\text { by } 5.2-5.3 \%, \\
P . \text { sp. } \mathrm{D}, \\
\text { differ by } 5.3 \% \text {, } \\
P . \text { sp. } \mathrm{H}, \\
\text { differ by } 5.3 \%, \\
P . \text { sp. I, } \\
\text { differ by } 5.1 \%\end{array}$ & $\begin{array}{l}\text { Bruneau Hot } \\
\text { Springs, Owyhee } \\
\text { Co., ID }\end{array}$ & \\
\hline & Pbr 1 & JN184636-645 & 10 & $0.00 \%$ & $\begin{array}{l}1.8 \% \text { with } \\
\text { bruneauensis }\end{array}$ & $\begin{array}{c}\text { P. kolobensis, } \\
\text { differ by } \\
5.2-6.5 \%, \\
\text { P. marcida, differ } \\
\text { by } 5.3 \% \text {, } \\
\text { P. pilsbryana, } \\
\text { differ by } 5.7 \% \text {, } \\
\text { P. variegata, } \\
\text { differ by } 5.3 \% \text {, } \\
\text { P. sp. B, differ } \\
\text { by } 5.3 \% \text {, } \\
\text { P. sp. C, differ } \\
\text { by } 5.6-5.8 \% \text {, } \\
\text { P. sp. D, differ } \\
\text { by } 5.7 \% \text {, } \\
\text { P. sp. H, differ } \\
\text { by } 5.8 \% \\
\text { P. sp. I, differ } \\
\text { by } 5.1 \%\end{array}$ & $\begin{array}{l}\text { Pool at mouth of } \\
\text { Hot Creek, Owyhee } \\
\text { Co., ID }\end{array}$ & \\
\hline
\end{tabular}




\begin{tabular}{|c|c|c|c|c|c|c|c|c|}
\hline Species & $\begin{array}{l}\text { Published } \\
\text { Sample } \\
\text { Codes }\end{array}$ & $\begin{array}{l}\text { Accession } \\
\text { Numbers }\end{array}$ & $\begin{array}{c}\text { No. of } \\
\text { Specimens }(\mathrm{N})\end{array}$ & $\begin{array}{l}\text { Sequence } \\
\text { Variation } \\
\text { (\% pairwise } \\
\text { distance) }\end{array}$ & $\begin{array}{c}\text { Most Distant } \\
\text { Conspecific } \\
\text { Sequences (\%) }\end{array}$ & $\begin{array}{c}\text { Closest } \\
\text { Interspecific } \\
\text { Sequences (\%) }\end{array}$ & Collection Locality & Comments \\
\hline \multirow[t]{3}{*}{$\begin{array}{l}\text { Pyrgulopsis } \\
\text { bruneauensis } \\
\text { (continued) }\end{array}$} & Pbr2 & JN184646-655 & 10 & $0-1.5 \%$ & $\begin{array}{l}0.3-1.8 \% \text { with } \\
\text { bruneauensis }\end{array}$ & \begin{tabular}{|} 
P. kolobensis, \\
differ by \\
$4.4-6.5 \%$, \\
P. marcida, differ \\
by $4.5-5.3 \%$, \\
P. pilsbryana, \\
differ by \\
$4.7-5.7 \%$, \\
P. variegata, \\
differ by \\
$4.3-5.3 \%$, \\
P. sp. B, differ \\
by $4.5-5.3 \%$, \\
P. sp. C, differ \\
by $4.6-5.8 \%$, \\
$P$. sp. D, differ \\
by $4.8-5.7 \%$, \\
$P$. sp. H. differ \\
by $4.7-5.8 \%$, \\
P. sp. I, differ \\
by $4.3-5.1 \%$
\end{tabular} & $\begin{array}{l}\text { Spring along } \\
\text { Bruneau River } \\
\text { below Hot Creek } \\
\text { confluence, } \\
\text { Owyhee Co., ID }\end{array}$ & \\
\hline & $\mathrm{Pbr} 3$ & JN184656-665 & 10 & $0-1.4 \%$ & $\begin{array}{l}0.7-1.8 \% \text { with } \\
\text { bruneauensis }\end{array}$ & \begin{tabular}{|} 
P. kolobensis, \\
differ by \\
$4.4-6.5 \%$, \\
P. marcida, differ \\
by $4.5-5.3 \%$, \\
P. pilsbryana, \\
differ by \\
$4.7-5.7 \%$, \\
P. variegata, \\
differ by \\
$4.3-5.3 \%$, \\
P. sp. B, differ \\
by $4.5-5.3 \%$, \\
P. sp. C, differ \\
by $4.6-5.8 \%$, \\
P. sp. D, differ \\
by $4.8-5.7 \%$, \\
P. sp. H, differ \\
by $4.7-5.8 \%$, \\
P. sp. I, differ \\
by $4.3-5.1 \%$
\end{tabular} & $\begin{array}{l}\text { Spring along } \\
\text { Bruneau River } \\
\text { above Hot Creek } \\
\text { confluence, } \\
\text { Owyhee Co., ID }\end{array}$ & \\
\hline & Pbr4 & JN184666-672 & 7 & $0-1.4 \%$ & $\begin{array}{l}0.7-1.8 \% \text { with } \\
\text { bruneauensis }\end{array}$ & \begin{tabular}{|c|} 
P. kolobensis, \\
differ by \\
$4.4-6.5 \%$, \\
P. marcida, differ \\
by $4.5-5.3 \%$, \\
P. pilsbryana, \\
differ by \\
$4.7-5.7 \%$, \\
P. variegata, \\
differ by \\
$4.3-5.3 \%$, \\
P. sp. B, differ \\
by $4.5-5.3 \%$, \\
P. sp. C, differ \\
by $4.6-5.8 \%$, \\
P. sp. D, differ \\
by $4.8-5.7 \%$, \\
P. sp. H, differ \\
by $4.7-5.8 \%$, \\
P. sp. I, differ \\
by $4.3-5.1 \%$
\end{tabular} & $\begin{array}{l}\text { Hot Creek } \\
\text { ca. } 100 \mathrm{~m} \text { upflow } \\
\text { from mouth, } \\
\text { Owyhee Co., ID }\end{array}$ & \\
\hline
\end{tabular}




\begin{tabular}{|c|c|c|c|c|c|c|c|c|}
\hline Species & $\begin{array}{l}\text { Published } \\
\text { Sample } \\
\text { Codes }\end{array}$ & $\begin{array}{l}\text { Accession } \\
\text { Numbers }\end{array}$ & $\begin{array}{c}\text { No. of } \\
\text { Specimens (N) }\end{array}$ & $\begin{array}{c}\text { Sequence } \\
\text { Variation } \\
\text { (\% pairwise } \\
\text { distance) }\end{array}$ & $\begin{array}{l}\text { Most Distant } \\
\text { Conspecific } \\
\text { Sequences (\%) }\end{array}$ & $\begin{array}{c}\text { Closest } \\
\text { Interspecific } \\
\text { Sequences (\%) }\end{array}$ & Collection Locality & Comments \\
\hline \multirow[t]{2}{*}{$\begin{array}{l}\text { Pyrgulopsis } \\
\text { bruneauensis } \\
\text { (continued) }\end{array}$} & Pbr5 & JN184673-679 & 7 & $0-1.5 \%$ & $\begin{array}{l}0.7-2.0 \% \text { with } \\
\text { bruneauensis }\end{array}$ & $\begin{array}{c}\text { P. kolobensis, } \\
\text { differ by } \\
4.7-6.7 \% \text {, } \\
\text { P. marcida, differ } \\
\text { by } 4.8-5.5 \% \text {, } \\
\text { P. pilsbryana, } \\
\text { differ by } \\
5.0-5.9 \%, \\
\text { P. variegata, } \\
\text { differ by } \\
4.7-5.4 \% \text {, } \\
\text { P. sp. B, differ } \\
\text { by } 4.8-5.5 \% \text {, } \\
\text { P. sp. C, differ } \\
\text { by } 4.9-6.0 \% \text {, } \\
\text { P. sp. D, differ } \\
\text { by } 5.2-5.8 \% \text {, } \\
\text { P. sp. H, differ } \\
\text { by } 5.0-5.9 \% \text {, } \\
\text { P. sp. I, differ } \\
\text { by } 4.6-5.3 \%\end{array}$ & $\begin{array}{l}\text { Spring along } \\
\text { Bruneau River } \\
\text { below Hot Creek } \\
\text { confluence, } \\
\text { Owyhee Co., ID }\end{array}$ & \\
\hline & Pbr6 & JN184680-686 & 7 & $0-1.4 \%$ & $\begin{array}{l}0.7-1.8 \% \text { with } \\
\text { bruneauensis }\end{array}$ & $\begin{array}{c}\text { P. kolobensis, } \\
\text { differ by } \\
4.4-6.5 \% \text {, } \\
\text { P. marcida, differ } \\
\text { by } 4.5-5.3 \% \text {, } \\
\text { P. pilsbryana, } \\
\text { differ by } \\
4.7-5.7 \% \text {, } \\
\text { P. variegata, } \\
\text { differ by } \\
4.3-5.3 \% \text {, } \\
\text { P. sp. B, differ } \\
\text { by } 4.5-5.3 \% \text {, } \\
\text { P. sp. C, differ } \\
\text { by } 4.6-5.8 \% \text {, } \\
\text { P. sp. D, differ } \\
\text { by } 4.8-5.7 \% \text {, } \\
\text { P. sp. H, differ } \\
\text { by } 4.7-5.8 \% \text {, } \\
\text { P. sp. I, differ } \\
\text { by } 4.3-5.1 \% \\
\end{array}$ & $\begin{array}{l}\text { Bruneau River } \\
\text { below Hot Creek } \\
\text { confluence, } \\
\text { Owyhee Co., ID }\end{array}$ & \\
\hline $\begin{array}{l}\text { Pyrgulopsis } \\
\text { bryantwalkeri }\end{array}$ & P121A & AY 627942 & 1 & $0.00 \%$ & & $\begin{array}{l}\text { P. aurata, differ } \\
\text { by } 0.3 \% \text {, } \\
\text { P. pictilis, differ } \\
\text { by } 0.3 \% \text {, } \\
\text { P. kolobensis, } \\
\text { differ by } \\
1.7-2.7 \% \text {, } \\
\text { P. nonaria, differ } \\
\text { by } 2.0 \% \text {, } \\
\text { P. variegata, } \\
\text { differ by } 2.0 \%, \\
\text { P. sp. B, differ } \\
\text { by } 1.9 \%\end{array}$ & $\begin{array}{l}\text { Warm Spring, } \\
\text { Humboldt River } \\
\text { drainage, Elko Co., } \\
\text { NV }\end{array}$ & \\
\hline \multirow[t]{2}{*}{$\begin{array}{l}\text { Pyrgulopsis } \\
\text { californiensis }\end{array}$} & P30 & DQ364019 & 3 & $0.00 \%$ & $3.4 \%$ with P31 & $\begin{array}{c}\text { P. kolobensis, } \\
\text { differ by } \\
4.1-5.3 \% \\
\text { P. variegata, } \\
\text { differ by } 4.3 \%\end{array}$ & $\begin{array}{l}\text { Spring tributary to } \\
\text { Lytle Creek, Santa } \\
\text { Ana River basin, } \\
\text { San Bernardino } \\
\text { Co., CA }\end{array}$ & \\
\hline & P31 & AY367481 & 1 & $0.00 \%$ & $3.4 \%$ with P30 & $\begin{array}{c}\text { P. chamberlini, } \\
\text { differ by } 5.1 \% \text {, } \\
\text { P. leporina, differ } \\
\text { by } 5.1 \%\end{array}$ & $\begin{array}{l}\text { Spring tributary } \\
\text { to Snow Creek, } \\
\text { Whitewater River } \\
\text { basin, Riverside } \\
\text { Co., CA }\end{array}$ & \\
\hline
\end{tabular}




\begin{tabular}{|c|c|c|c|c|c|c|c|c|}
\hline Species & $\begin{array}{l}\text { Published } \\
\text { Sample } \\
\text { Codes }\end{array}$ & $\begin{array}{l}\text { Accession } \\
\text { Numbers }\end{array}$ & $\begin{array}{c}\text { No. of } \\
\text { Specimens }(N)\end{array}$ & $\begin{array}{l}\text { Sequence } \\
\text { Variation } \\
\text { (\% pairwise } \\
\text { distance) }\end{array}$ & $\begin{array}{l}\text { Most Distant } \\
\text { Conspecific } \\
\text { Sequences (\%) }\end{array}$ & $\begin{array}{c}\text { Closest } \\
\text { Interspecific } \\
\text { Sequences (\%) }\end{array}$ & Collection Locality & Comments \\
\hline $\begin{array}{l}\text { Pyrgulopsis } \\
\text { californiensis } \\
\text { (continued) }\end{array}$ & P33 & AY 627924 & 2 & $0.00 \%$ & $7.0 \%$ with P30 & $\begin{array}{l}\text { P. longinqua, } \\
\text { differ by } 2.4 \%\end{array}$ & $\begin{array}{l}\text { Spring tributary } \\
\text { to Campo Creek, } \\
\text { Southern California } \\
\text { coastal drainage, } \\
\text { San Diego Co., CA }\end{array}$ & \\
\hline $\begin{array}{l}\text { Pyrgulopsis } \\
\text { carinifera }\end{array}$ & P9 & AY 627920 & 1 & $0.00 \%$ & & $\begin{array}{c}\text { P. archimedis, } \\
\text { differ by } \\
6.3-7.5 \% \text {, } \\
\text { P. bruneauensis, } \\
\text { differ by } \\
6.9-7.5 \% \text {, } \\
\text { P. lentiglans, } \\
\text { differ by } 6.9 \% \text {, } \\
\text { P. thermalis, } \\
\text { differ by } \\
6.0-12.1 \%\end{array}$ & $\begin{array}{l}\text { Muddy Spring, } \\
\text { Moapa Valley, } \\
\text { Clark Co., NV }\end{array}$ & \\
\hline $\begin{array}{l}\text { Pyrgulopsis } \\
\text { castaicensis }\end{array}$ & & GQ275097 & 3 & $0.00 \%$ & & $\begin{array}{c}\text { P. hualapaiensis, } \\
\text { differ by } 3.3 \%\end{array}$ & $\begin{array}{l}\text { Middle Canyon } \\
\text { Spring, Southern } \\
\text { California coastal } \\
\text { drainage, Los } \\
\text { Angeles Co., CA }\end{array}$ & $\begin{array}{l}\text { Pyrgulopsis } \\
\text { sp. } 1 \text { HPL- } \\
2009 \text { in } \\
\text { GenBank }\end{array}$ \\
\hline $\begin{array}{l}\text { Pyrgulopsis } \\
\text { chamberlini }\end{array}$ & P101A & EU700468 & 1 & $0.00 \%$ & & $\begin{array}{c}\text { P. variegata, } \\
\text { differ by } 1.9 \% \text {, } \\
\text { P. sp. B, differ } \\
\text { by } 1.8 \% \text {, } \\
\text { P. sp. } 1, \text { differ } \\
\text { by } 1.9 \%\end{array}$ & $\begin{array}{l}\text { Spring at } \\
\text { Glenwood, Sevier } \\
\text { River drainage, } \\
\text { Sevier Co., UT }\end{array}$ & \\
\hline $\begin{array}{l}\text { Prygulopsis } \\
\text { cinerana }\end{array}$ & $A C$ & AY197602 & 1 & $0.00 \%$ & & $\begin{array}{l}\text { P. falciglans, } \\
\text { differ by } 4.8 \%\end{array}$ & $\begin{array}{l}\text { Ash Creek, } \\
\text { Pit River basin, } \\
\text { Lassen Co., CA }\end{array}$ & \\
\hline $\begin{array}{l}\text { Pyrgulopsis } \\
\text { coloradensis }\end{array}$ & BP1A & KP899919 & 1 & $0.00 \%$ & & $\begin{array}{l}\text { P. sanchezi, } \\
\text { differ by } \\
3.8-5.0 \%\end{array}$ & $\begin{array}{l}\text { Blue Point Spring, } \\
\text { Clark Co., NV }\end{array}$ & \\
\hline \multirow[t]{2}{*}{$\begin{array}{l}\text { Pyrgulopsis } \\
\text { conica }\end{array}$} & DS & AY 627958 & 1 & $0.00 \%$ & $0.0 \%$ with Pcon 1 & $\begin{array}{l}\text { P. glandulosa, } \\
\text { differ by } \\
2.6-3.0 \% \text {, } \\
\text { P. perforata, } \\
\text { differ by } \\
2.6-2.7 \%\end{array}$ & $\begin{array}{l}\text { Dripping Spring, } \\
\text { Sacramento Wash, } \\
\text { Mohave Co., AZ }\end{array}$ & \\
\hline & Pconl & AY 485546 & 30 & $0.00 \%$ & $0.0 \%$ with DS & $\begin{array}{l}\text { P. glandulosa, } \\
\text { differ by } \\
2.6-3.0 \% \text {, } \\
\text { P. perforata, } \\
\text { differ by } \\
2.6-2.7 \%\end{array}$ & Dripping & Hurt (2004) \\
\hline $\begin{array}{l}\text { Pyrgulopsis } \\
\text { cruciglans }\end{array}$ & P70A & AY 627931 & 1 & $0.00 \%$ & & $\begin{array}{c}\text { P. kolobensis, } \\
\text { differ by } \\
3.0-4.2 \% \\
\text { P. marcida, } \\
\text { differ by } 3.3 \% \text {, } \\
\text { P. variegata, } \\
\text { differ by } 3.3 \%\end{array}$ & $\begin{array}{l}\text { Flat Spring, } \\
\text { Steptoe Valley, } \\
\text { White Pine Co., NV }\end{array}$ & \\
\hline
\end{tabular}




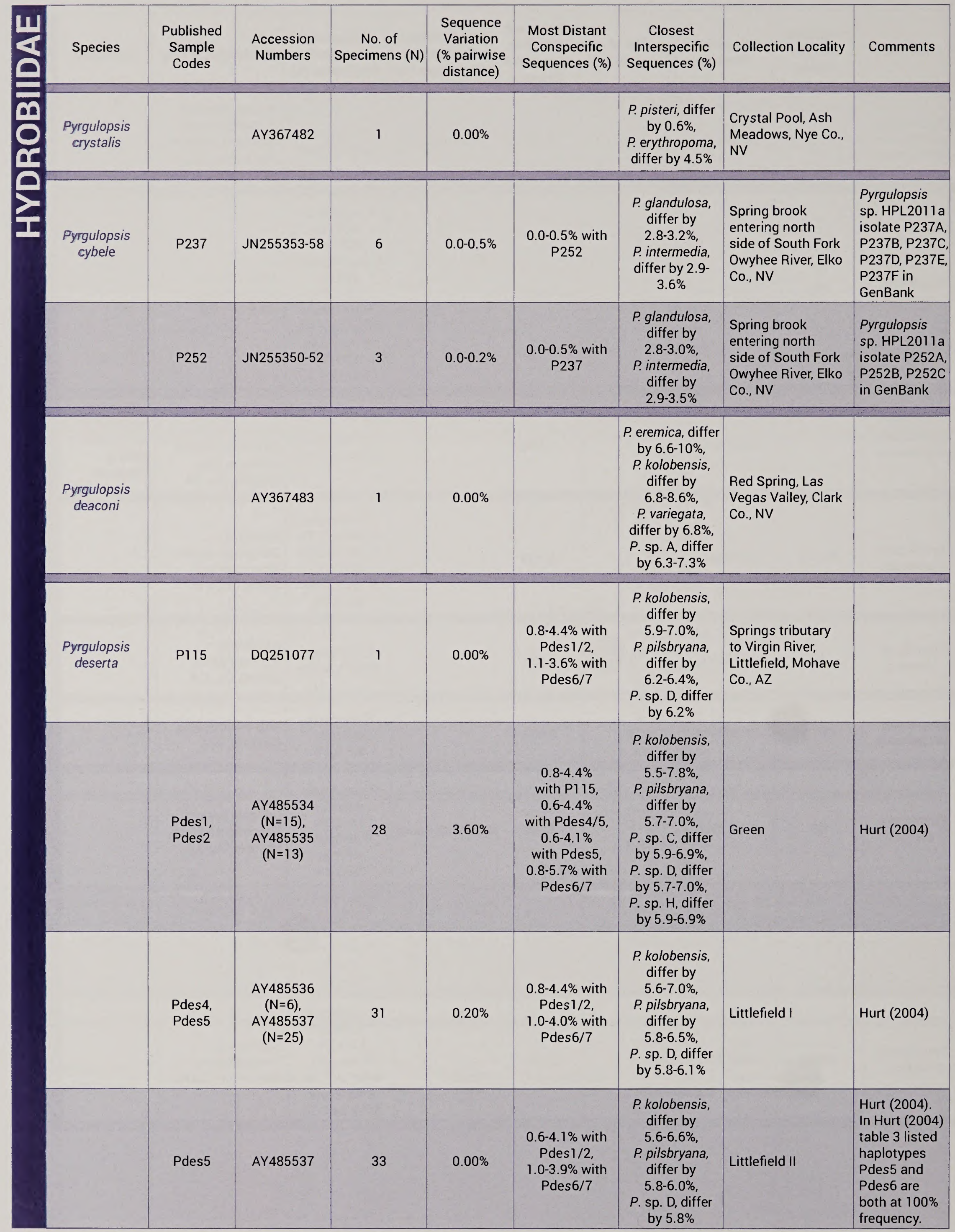




\begin{tabular}{|c|c|c|c|c|c|c|c|c|}
\hline Species & $\begin{array}{l}\text { Published } \\
\text { Sample } \\
\text { Codes }\end{array}$ & $\begin{array}{l}\text { Accession } \\
\text { Numbers }\end{array}$ & $\begin{array}{c}\text { No. of } \\
\text { Specimens (N) }\end{array}$ & $\begin{array}{c}\text { Sequence } \\
\text { Variation } \\
(\% \text { pairwise } \\
\text { distance })\end{array}$ & $\begin{array}{l}\text { Most Distant } \\
\text { Conspecific } \\
\text { Sequences (\%) }\end{array}$ & $\begin{array}{c}\text { Closest } \\
\text { Interspecific } \\
\text { Sequences (\%) }\end{array}$ & Collection Locality & Comments \\
\hline $\begin{array}{l}\text { Pyrgulopsis } \\
\text { deserta } \\
\text { (continued) }\end{array}$ & $\begin{array}{l}\text { Pdes6, } \\
\text { Pdes7 }\end{array}$ & $\begin{array}{l}\text { AY } 485536 \\
(N=17) \\
\text { AY } 485537 \\
(N=14)\end{array}$ & 31 & $2.70 \%$ & $\begin{array}{c}1.1-3.6 \% \\
\text { with } \mathrm{P} 115 \\
0.8-5.7 \% \\
\text { with } \mathrm{Pdes} 1 / 2 \\
1.0-4.0 \% \\
\text { with } \mathrm{Pdes} 4 / 5 \\
1.0-3.9 \% \\
\text { with Pdes } 5\end{array}$ & $\begin{array}{c}\text { P. kolobensis, } \\
\text { differ by } \\
6.0-7.7 \% \text {, } \\
\text { P. pilsbryana, } \\
\text { differ by } \\
6.3-6.6 \% \text {, } \\
\text { P. sp. C. differ } \\
\text { by } 6.4-6.7 \% \text {, } \\
\text { P. sp. D, differ } \\
\text { by } 6.3-6.5 \% \text {, } \\
\text { P. sp. } \mathrm{H} \text {, differ } \\
\text { by } 6.4-6.6 \%\end{array}$ & Red Hill & Hurt (2004) \\
\hline $\begin{array}{l}\text { Pyrgulopsis } \\
\text { diablensis }\end{array}$ & P25 & AY627922 & 2 & $0.00 \%$ & & $\begin{array}{l}\text { P. giulianii, } \\
\text { differ by } 1.1 \%\end{array}$ & $\begin{array}{l}\text { Stream, Del Puerto } \\
\text { Canyon, San } \\
\text { Joaquin River basin, } \\
\text { Stanislaus Co., CA }\end{array}$ & \\
\hline $\begin{array}{l}\text { Pyrgulopsis } \\
\text { dixensis }\end{array}$ & $\mathrm{P} 143$ & AY627946 & 1 & $0.00 \%$ & & $\begin{array}{c}\text { P. bruesi, } \\
\text { differ by } 0.3 \% \text {, } \\
\text { P. montana, } \\
\text { differ by } 3.1 \%\end{array}$ & $\begin{array}{l}\text { Spring west of Cain } \\
\text { Mountain, Dixie } \\
\text { Valley, Pershing } \\
\text { Co., NV }\end{array}$ & \\
\hline \multirow[t]{4}{*}{$\begin{array}{l}\text { Pyrgulopsis } \\
\text { eremica }\end{array}$} & P145 & AY627947 & 1 & $0.00 \%$ & $\begin{array}{c}7.1 \% \text { with EL_a, } \\
7.0-7.1 \% \text { with } \\
\text { EL_b }\end{array}$ & $\begin{array}{l}\text { P. lasseni, differ } \\
\text { by } 0.3 \% \text {, } \\
\text { P. kolobensis, } \\
\text { differ by } \\
4.9-6.1 \% \text {, } \\
\text { P. pilsbryana, } \\
\text { differ by } \\
5.1-5.4 \% \text {, } \\
\text { P. sp. D, differ } \\
\text { by } 5.1 \%\end{array}$ & $\begin{array}{l}\text { Spring, tributary to } \\
\text { Willow Creek, Eagle } \\
\text { Lake basin, Lassen } \\
\text { Co., CA }\end{array}$ & $\begin{array}{l}\text { This } \\
\text { sequence } \\
\text { does not } \\
\text { appear to } \\
\text { be that of } P \text {. } \\
\text { eremica (per } \\
\text { Hershler et } \\
\text { al. 2003a) } \\
\text { and was } \\
\text { apparently } \\
\text { submitted to } \\
\text { GenBank in } \\
\text { error }\end{array}$ \\
\hline & $\mathrm{HC}$ & AY197597 & 1 & $0.00 \%$ & $7 \%$ with P145 & $\begin{array}{l}\text { P. kolobensis, } \\
\text { differ by } \\
3.7-5.3 \% \text {, } \\
\text { P. sp. D. differ } \\
\text { by } 3.7 \%\end{array}$ & $\begin{array}{l}\text { Spring west of } \\
\text { Russell Dairy } \\
\text { Spring, Pit River } \\
\text { basin, Lassen Co., } \\
\text { CA }\end{array}$ & \\
\hline & EL_a & AY197598 & 1 & $0.00 \%$ & $7.1 \%$ with P1 45 & $\begin{array}{l}\text { P. kolobensis, } \\
\text { differ by } \\
3.9-5.5 \% \text {, } \\
\text { P. sp. D, differ } \\
\text { by } 3.9 \%\end{array}$ & $\begin{array}{l}\text { Troxel Point Spring, } \\
\text { Honey-Eagle Lakes } \\
\text { basin, Lassen Co., } \\
\text { CA }\end{array}$ & \\
\hline & EL_b & AY $197599-600$ & 2 & $0.20 \%$ & $\begin{array}{c}7.0-7.1 \% \text { with } \\
\text { P145 }\end{array}$ & $\begin{array}{l}\text { P. kolobensis, } \\
\text { differ by } \\
3.9-5.5 \% \text {, } \\
\text { P. sp. D, differ } \\
\text { by } 3.9-4.1 \%\end{array}$ & $\begin{array}{l}\text { Murrers Upper } \\
\text { Meadow, Honey- } \\
\text { Eagle Lakes basin, } \\
\text { Lassen Co., CA }\end{array}$ & \\
\hline $\begin{array}{l}\text { Pyrgulopsis } \\
\text { erythropoma }\end{array}$ & & AY367484 & 4 & $0.00 \%$ & & $\begin{array}{l}\text { P. crystalis, } \\
\text { differ by } 4.5 \% \text {, } \\
\text { P. pisteri, differ } \\
\text { by } 4.5 \%\end{array}$ & $\begin{array}{l}\text { Kings Pool } \\
\text { (outflow), Point } \\
\text { of Rocks, Ash } \\
\text { Meadows, Nye Co., } \\
\text { NV }\end{array}$ & \\
\hline $\begin{array}{c}\text { Pyrgulopsis } \\
\text { fairbanksensis }\end{array}$ & P19 & AY627921 & 1 & $0.00 \%$ & & $\begin{array}{l}\text { P. isolata, differ } \\
\text { by } 0.5 \% \text {, } \\
\text { P. nanus, differ } \\
\text { by } 1.3 \%\end{array}$ & $\begin{array}{l}\text { Fairbanks Spring, } \\
\text { Ash Meadows, Nye } \\
\text { Co., NV }\end{array}$ & \\
\hline
\end{tabular}




\begin{tabular}{|c|c|c|c|c|c|c|c|c|}
\hline Species & $\begin{array}{l}\text { Published } \\
\text { Sample } \\
\text { Codes }\end{array}$ & $\begin{array}{l}\text { Accession } \\
\text { Numbers }\end{array}$ & $\begin{array}{c}\text { No. of } \\
\text { Specimens }(N)\end{array}$ & $\begin{array}{l}\text { Sequence } \\
\text { Variation } \\
\text { (\% pairwise } \\
\text { distance) }\end{array}$ & $\begin{array}{l}\text { Most Distant } \\
\text { Conspecific } \\
\text { Sequences (\%) }\end{array}$ & $\begin{array}{c}\text { Closest } \\
\text { Interspecific } \\
\text { Sequences (\%) }\end{array}$ & Collection Locality & Comments \\
\hline $\begin{array}{l}\text { Pyrgulopsis } \\
\text { falciglans }\end{array}$ & SC & AY197601 & 1 & & & $\begin{array}{l}\text { P. cinerana, } \\
\text { differ by } 4.8 \%\end{array}$ & $\begin{array}{l}\text { Smokey Charley } \\
\text { Spring, Modoc Co., } \\
\text { CA }\end{array}$ & \\
\hline $\begin{array}{l}\text { Pyrgulopsis } \\
\text { fausta }\end{array}$ & & AY367485 & 1 & $0.00 \%$ & & $\begin{array}{l}\text { P. longiglans, } \\
\text { differ by } 6.3 \% \text {, } \\
\text { P. trivialis, differ } \\
\text { by } 6.3-6.4 \%\end{array}$ & $\begin{array}{l}\text { Corn Creek Springs, } \\
\text { Las Vegas Valley, } \\
\text { Clark Co., NV }\end{array}$ & \\
\hline \multirow[t]{6}{*}{$\begin{array}{l}\text { Pyrgulopsis } \\
\text { fresti }\end{array}$} & IP68 & $\begin{array}{l}\text { FJ172470 } \\
\text { (IP68A), } \\
\text { FJ172471 } \\
\text { (IP68B), } \\
\text { FJ172472 } \\
\text { (IP68C) }\end{array}$ & 3 & $0.2-0.3 \%$ & $\begin{array}{c}2.1-2.3 \% \\
\text { with IP69B }\end{array}$ & $\begin{array}{c}\text { P. kolobensis, } \\
\text { differ by } \\
6.2-7.6 \% \text {, } \\
\text { P. marcida, differ } \\
\text { by } 6.5-6.7 \% \text {, } \\
\text { P. plicata, differ } \\
\text { by } 6.5-6.7 \% \text {, } \\
\text { P. serrata, differ } \\
\text { by } 6.4-6.6 \% \text {, } \\
\text { P. variegata, } \\
\text { differ by } \\
6.5-6.7 \% \text {, } \\
\text { P. sp. C, differ } \\
\text { by } 6.5-6.9 \%\end{array}$ & $\begin{array}{l}\text { Tudor Warm } \\
\text { Springs, east } \\
\text { side of Owyhee } \\
\text { River, fourth spring } \\
\text { from north, } \\
\text { Malheur Co., OR }\end{array}$ & $\begin{array}{l}\text { Pyrgulopsis } \\
\text { sp. } 2 \\
\text { HPL2008 } \\
\text { isolate IP68A, } \\
\text { IP68B. IP68C } \\
\text { in GenBank }\end{array}$ \\
\hline & IP69B & FJ172473 & 1 & $0.00 \%$ & $\begin{array}{l}2.5 \% \\
\text { with P207A }\end{array}$ & $\begin{array}{c}\text { P. kolobensis, } \\
\text { differ by } \\
6.3-7.3 \% \text {, } \\
\text { P. marcida, } \\
\text { differ by } 6.4 \% \text {, } \\
\text { P. plicata, } \\
\text { differ by } 6.4 \% \text {, } \\
\text { P. rupinicola, } \\
\text { differ by } \\
6.4-6.6 \% \text {, } \\
\text { P. variegata, } \\
\text { differ by } 6.4 \%\end{array}$ & $\begin{array}{l}\text { Tudor Warm } \\
\text { Springs, west side } \\
\text { of Owyhee River, } \\
\text { first spring north } \\
\text { of mouth of Warm } \\
\text { Springs Canyon, } \\
\text { Malheur Co., OR }\end{array}$ & $\begin{array}{l}\text { Pyrgulopsis } \\
\text { sp. } 2 \\
\text { HPL2008 } \\
\text { isolate IP69B } \\
\text { in GenBank }\end{array}$ \\
\hline & P176B & FJ172474 & 1 & $0.00 \%$ & $\begin{array}{c}2.1 \% \\
\text { with IP69B }\end{array}$ & $\begin{array}{l}\text { P. kolobensis, } \\
\text { differ by } \\
6.2-7.3 \% \text {, } \\
\text { P. neritella, } \\
\text { differ by } 6.3 \%\end{array}$ & $\begin{array}{l}\text { Tudor Warm } \\
\text { Springs, east side } \\
\text { of Owyhee River, } \\
\text { second spring from } \\
\text { north, Malheur Co., } \\
\text { OR }\end{array}$ & $\begin{array}{l}\text { Pyrgulopsis } \\
\text { sp. } 2 \\
\text { HPL2008 } \\
\text { isolate } \\
\text { IP176B in } \\
\text { GenBank }\end{array}$ \\
\hline & P207A & FJ172476 & 2 & $0.00 \%$ & $\begin{array}{l}2.5 \% \\
\text { with IP69B }\end{array}$ & $\begin{array}{l}\text { P. kolobensis, } \\
\text { differ by } \\
5.9-7.4 \% \text {, } \\
\text { P. neritella, } \\
\text { differ by } 6.1 \%\end{array}$ & $\begin{array}{l}\text { Spring tributary to } \\
\text { Owyhee River } \\
\text { upflow from Tudor } \\
\text { Warm Springs, } \\
\text { Malheur Co., OR }\end{array}$ & $\begin{array}{l}\text { Pyrgulopsis } \\
\text { sp. } 2 \\
\text { HPL2008 } \\
\text { isolate } \\
\text { IP207A in } \\
\text { GenBank }\end{array}$ \\
\hline & P208 & $\begin{array}{l}\text { FJ172477 } \\
(P 208 A) \\
\text { FJ172478 } \\
\text { (P208E) }\end{array}$ & 5 & $0.80 \%$ & $\begin{array}{c}1.6-2.1 \% \\
\text { with IP69B }\end{array}$ & $\begin{array}{l}\text { P. kolobensis, } \\
\text { differ by } \\
6.1-7.3 \% \text {, } \\
\text { P. serrata, differ } \\
\text { by } 6.3-6.4 \%\end{array}$ & $\begin{array}{l}\text { Spring complex } \\
\text { along Owyhee River } \\
\text { upflow from Tudor } \\
\text { Warm Springs, } \\
\text { Malheur Co., OR }\end{array}$ & $\begin{array}{l}\text { Pyrgulopsis } \\
\text { sp. } 2 \\
\text { HPL2008 } \\
\text { isolate } \\
\text { IP208A, } \\
\text { IP208E in } \\
\text { GenBank }\end{array}$ \\
\hline & P210 & FJ172480 & 3 & $0.00 \%$ & $\begin{array}{c}2.1 \% \\
\text { with IP69B }\end{array}$ & $\begin{array}{l}\text { P. kolobensis, } \\
\text { differ by } \\
6.2-7.4 \% \text {, } \\
\text { P. serrata, } \\
\text { differ by } 6.4 \%\end{array}$ & $\begin{array}{l}\text { Tudor Warm } \\
\text { Springs, east side of } \\
\text { Owyhee River, third } \\
\text { spring from north, } \\
\text { Malheur Co., OR }\end{array}$ & $\begin{array}{l}\text { Pyrgulopsis } \\
\text { sp. } 2 \\
\text { HPL2008 } \\
\text { isolate } \\
\text { IP210A in } \\
\text { GenBank }\end{array}$ \\
\hline . & $\mathrm{P} 212$ & FJ172483 & 2 & $0.00 \%$ & $\begin{array}{c}2.1 \% \\
\text { with IP69B }\end{array}$ & $\begin{array}{l}\text { P. kolobensis, } \\
\text { differ by } \\
6.2-7.4 \% \text {, } \\
\text { P. serrata, } \\
\text { differ by } 6.4 \%\end{array}$ & $\begin{array}{l}\text { Tudor Warm } \\
\text { Springs, east side } \\
\text { of Owyhee River, } \\
\text { second spring from } \\
\text { north, Malheur Co., } \\
\text { OR }\end{array}$ & $\begin{array}{l}\text { Pyrgulopsis } \\
\text { sp. } 2 \\
\text { HPL2008 } \\
\text { isolate } \\
\text { IP212A in } \\
\text { GenBank0 }\end{array}$ \\
\hline
\end{tabular}




\begin{tabular}{|c|c|c|c|c|c|c|c|c|}
\hline Species & $\begin{array}{l}\text { Published } \\
\text { Sample } \\
\text { Codes }\end{array}$ & $\begin{array}{l}\text { Accession } \\
\text { Numbers }\end{array}$ & $\begin{array}{c}\text { No. of } \\
\text { Specimens }(\mathrm{N})\end{array}$ & $\begin{array}{l}\text { Sequence } \\
\text { Variation } \\
\text { (\% pairwise } \\
\text { distance) }\end{array}$ & $\begin{array}{l}\text { Most Distant } \\
\text { Conspecific } \\
\text { Sequences (\%) }\end{array}$ & $\begin{array}{c}\text { Closest } \\
\text { Interspecific } \\
\text { Sequences (\%) }\end{array}$ & Collection Locality & Comments \\
\hline \multirow[t]{2}{*}{$\begin{array}{l}\text { Pyrgulopsis } \\
\text { gibba }\end{array}$} & P134/SV & $\begin{array}{l}\text { AY197603, } \\
\text { AY426359 }\end{array}$ & 2 & $0.00 \%$ & $\begin{array}{c}1.0 \% \\
\text { with P192 }\end{array}$ & $\begin{array}{l}\text { P. vinyardi, differ } \\
\text { by } 0.5 \% \text {, } \\
\text { P. kolobensis, } \\
\text { differ by } \\
4.6-5.9 \% \\
\text { P. nonaria, differ } \\
\text { by } 4.4-4.8 \%\end{array}$ & $\begin{array}{l}\text { Spring west of Fee } \\
\text { Reservoir, Surprise } \\
\text { Valley, Modoc Co., } \\
\text { CA }\end{array}$ & \\
\hline & P192 & DQ364016 & 1 & $0.00 \%$ & $\begin{array}{c}1.0 \% \\
\text { with P134 }\end{array}$ & $\begin{array}{l}\text { P. vinyardi, differ } \\
\text { by } 1.1 \% \text {, } \\
\text { P. kolobensis, } \\
\text { differ by } \\
4.6-5.5 \% \text {, } \\
\text { P. nonaria, differ } \\
\text { by } 4.6 \%\end{array}$ & $\begin{array}{l}\text { Spring along } \\
\text { Hwy } 395 \text { below } \\
\text { Bridgeport } \\
\text { Reservoir, Walker } \\
\text { River basin, Mono } \\
\text { Co., CA }\end{array}$ & \\
\hline \multirow[t]{8}{*}{$\begin{array}{l}\text { Pyrgulopsis } \\
\text { gilae }\end{array}$} & G1 & $\begin{array}{c}K C 571284 \\
(N=2), \\
K C 571285 \\
(N=1)\end{array}$ & 3 & $0-1.2 \%$ & $\begin{array}{l}0.6-1.5 \% \text { with } \\
\text { Pgil3 and Pgil4 }\end{array}$ & $\begin{array}{l}\text { P. marilynae, } \\
\text { differ by } \\
3.8-4.0 \%\end{array}$ & $\begin{array}{l}\text { Spring along East } \\
\text { Fork Gila River, ca. } \\
1.53 \mathrm{~km} \text { north, } 2.9 \\
\mathrm{~km} \text { east of State } \\
\text { Route } 527 \text { bridge } \\
\text { crossing, Grant Co., } \\
\text { NM }\end{array}$ & \\
\hline & $\mathrm{G} 2$ & $\begin{array}{c}\mathrm{KC571286} \\
(\mathrm{N}=9) \\
\mathrm{KC571287} \\
(\mathrm{N}=1)\end{array}$ & 10 & $0-0.2 \%$ & $\begin{array}{l}0.6-1.0 \% \text { with } \\
\text { Pgil3 and Pgil4 }\end{array}$ & $\begin{array}{l}\text { P. marilynae, } \\
\text { differ by } \\
3.5-3.8 \%\end{array}$ & $\begin{array}{l}\text { Spring along East } \\
\text { Fork Gila River, ca. } \\
1.29 \mathrm{~km} \text { north, } 0.56 \\
\mathrm{~km} \text { west of Black } \\
\text { Canyon confluence, } \\
\text { Grant Co., NM }\end{array}$ & \\
\hline & G3 & $\begin{array}{l}\text { KC571288 } \\
(N=4), \\
\text { KC571289 } \\
(N=1), \\
\text { KC571290 } \\
(N=1)\end{array}$ & 6 & $0-0.3 \%$ & $\begin{array}{l}0.5-1.2 \% \\
\text { with G1 }\end{array}$ & $\begin{array}{l}\text { P. marilynae, } \\
\text { differ by } \\
3.6-4.0 \%\end{array}$ & $\begin{array}{l}\text { Spring along East } \\
\text { Fork Gila River, ca. } \\
1.53 \mathrm{~km} \text { north, } 2.38 \\
\mathrm{~km} \text { east of State } \\
\text { Route } 527 \text { bridge } \\
\text { crossing, Grant Co., } \\
\text { NM }\end{array}$ & \\
\hline & G14 & $\begin{array}{c}\mathrm{KC5} 51288 \\
(N=2) \\
\mathrm{KC571306} \\
(N=1)\end{array}$ & 3 & $0-0.2 \%$ & $\begin{array}{l}0.5-1.2 \% \\
\text { with G1 }\end{array}$ & $\begin{array}{l}\text { P. marilynae, } \\
\text { differ by } \\
3.6-4.0 \%\end{array}$ & $\begin{array}{l}\text { Alum Hot Spring, } \\
\text { ca. } 1.93 \mathrm{~km} \text { south, } \\
0.16 \mathrm{~km} \text { west of } \\
\text { State Route } 527 \\
\text { bridge crossing, } \\
\text { Grant Co., NM }\end{array}$ & \\
\hline & Pgilae & AY627952 & 1 & $0.00 \%$ & $\begin{array}{l}0.0-1.3 \% \\
\text { with G1 }\end{array}$ & $\begin{array}{l}\text { P. marilynae, } \\
\text { differ by } \\
3.8-4.0 \%\end{array}$ & $\begin{array}{l}\text { Spring tributary to } \\
\text { East Fork Gila River, } \\
\text { Grant Co., NM }\end{array}$ & \\
\hline & $\begin{array}{l}\text { Pgil1, } \\
\text { Pgil2 }\end{array}$ & $\begin{array}{c}\text { AY } 485570 \\
(N=18) \\
\text { AY485571 } \\
(N=14)\end{array}$ & 32 & $0-0.2 \%$ & $\begin{array}{l}0.0-1.4 \% \\
\text { with } \mathrm{G} 1\end{array}$ & $\begin{array}{l}\text { P. marilynae, } \\
\text { differ by } \\
3.2-3.6 \%\end{array}$ & Gila I & Hurt (2004) \\
\hline & $\begin{array}{l}\text { Pgil3, } \\
\text { Pgil4 }\end{array}$ & $\begin{array}{c}\text { AY } 485572 \\
(N=28) \\
\text { AY485573 } \\
(N=1)\end{array}$ & 29 & $0-0.4 \%$ & $\begin{array}{l}0.6-1.5 \% \\
\text { with G } 1\end{array}$ & $\begin{array}{l}\text { P. marilynae, } \\
\text { differ by } \\
3.5-3.8 \%\end{array}$ & Gila II & Hurt (2004) \\
\hline & Pgil3 & AY485572 & 29 & $0.00 \%$ & $\begin{array}{l}0.6-1.2 \% \\
\text { with G1 }\end{array}$ & $\begin{array}{l}\text { P. marilynae, } \\
\text { differ by } \\
3.5-3.6 \%\end{array}$ & Gila III & Hurt (2004) \\
\hline
\end{tabular}




\begin{tabular}{|c|c|c|c|c|c|c|c|c|}
\hline Species & $\begin{array}{l}\text { Published } \\
\text { Sample } \\
\text { Codes }\end{array}$ & $\begin{array}{l}\text { Accession } \\
\text { Numbers }\end{array}$ & $\begin{array}{c}\text { No. of } \\
\text { Specimens }(\mathrm{N})\end{array}$ & $\begin{array}{l}\text { Sequence } \\
\text { Variation } \\
\text { (\% pairwise } \\
\text { distance) }\end{array}$ & $\begin{array}{l}\text { Most Distant } \\
\text { Conspecific } \\
\text { Sequences (\%) }\end{array}$ & $\begin{array}{c}\text { Closest } \\
\text { Interspecific } \\
\text { Sequences (\%) }\end{array}$ & Collection Locality & Comments \\
\hline \multirow[t]{2}{*}{$\begin{array}{l}\text { Pyrgulopsis } \\
\text { giulianii }\end{array}$} & M23 & AF520937 & 1 & $0.00 \%$ & $0 \%$ with P21 & $\begin{array}{l}\text { P. diablensis, } \\
\text { differ by } 1.1 \%\end{array}$ & $\begin{array}{l}\text { Stream, Sand } \\
\text { Canyon, Indian } \\
\text { Wells Valley } \\
\text { (Northern Mojave } \\
\text { basin), Kern Co., CA }\end{array}$ & $\begin{array}{l}\text { P. guiliani in } \\
\text { GenBank }\end{array}$ \\
\hline & P21 & DQ364018 & 1 & $0.00 \%$ & $0 \%$ with $\mathrm{M} 23$ & $\begin{array}{l}\text { P. diablensis, } \\
\text { differ by } 1.1 \%\end{array}$ & $\begin{array}{l}\text { Dougherty Creek, } \\
\text { Hwy } 178 \text { crossing, } \\
\text { Kern River basin, } \\
\text { Kern Co., CA }\end{array}$ & \\
\hline \multirow[t]{2}{*}{$\begin{array}{l}\text { Pyrgulopsis } \\
\text { glandulosa }\end{array}$} & NP2 & AY627959 & 1 & $0.00 \%$ & $0 \%$ with Pglal & $\begin{array}{l}\text { P. intermedia, } \\
\text { differ by } \\
2.1-2.6 \%\end{array}$ & $\begin{array}{l}\text { Nelson Place } \\
\text { Spring, Verde River } \\
\text { basin, Yavapai Co., } \\
\text { AZ }\end{array}$ & \\
\hline & Pglal & AY 485557 & 25 & $0.00 \%$ & $0 \%$ with NP2 & $\begin{array}{l}\text { P. intermedia, } \\
\text { differ by } \\
2.2-2.4 \%\end{array}$ & Nelson Place & Hurt (2004) \\
\hline $\begin{array}{l}\text { Pyrgulopsis } \\
\text { gracilis }\end{array}$ & P60 & DQ364011 & 1 & $0.00 \%$ & & $\begin{array}{c}\text { P. hubbsi, } \\
\text { differ by } 3.2 \% \text {, } \\
\text { P. sathos, } \\
\text { differ by } 3.2 \%\end{array}$ & $\begin{array}{l}\text { Emigrant Springs } \\
\text { (north), White River } \\
\text { Valley, Nye Co., NV }\end{array}$ & \\
\hline $\begin{array}{c}\text { Pyrgulopsis } \\
\text { greggi }\end{array}$ & $\mathrm{P} 22$ & $\begin{array}{l}\text { AF520943 } \\
(N=3) \\
\text { GQ275088 } \\
(N=2)\end{array}$ & 5 & $0-0.3 \%$ & & $\begin{array}{l}\text { P. kolobensis, } \\
\text { differ by } \\
4.3-6.5 \% \text {, } \\
\text { P. pilsbryana, } \\
\text { differ by } \\
4.8-5.7 \% \text {, } \\
\text { P. transversa, } \\
\text { differ by } \\
4.6-5.3 \% \text {, } \\
\text { P. sp. C, differ } \\
\text { by } 4.8-5.5 \% \text {, } \\
\text { P. sp. H, differ } \\
\text { by } 4.8-5.3 \%\end{array}$ & $\begin{array}{l}\text { Grapevine Creek, } \\
\text { Fort Tejon Historic } \\
\text { State Park, Kern } \\
\text { Co., CA }\end{array}$ & \\
\hline $\begin{array}{l}\text { Pyrgulopsis } \\
\text { hualapaiensis }\end{array}$ & & KU720383 & 1 & $0.00 \%$ & & $\begin{array}{l}\text { P. conica, differ } \\
\text { by } 2.9 \% \text {, } \\
\text { P. milleri, differ } \\
\text { by } 2.9 \% \text {, } \\
\text { P. thompsoni, } \\
\text { differ by } \\
2.5-4.0 \%\end{array}$ & $\begin{array}{l}\text { Upper Peach } \\
\text { Springs, outflow } \\
\text { just below concrete } \\
\text { weir, Hualapai } \\
\text { Indian Reservation, } \\
\text { Mohave Co., AZ }\end{array}$ & \\
\hline $\begin{array}{c}\text { Pyrgulopsis } \\
\text { hubbsi }\end{array}$ & P7B & AY627918 & 1 & $0.00 \%$ & & $\begin{array}{l}\text { P. sathos, } \\
\text { differ by } 1 \%\end{array}$ & $\begin{array}{l}\text { Crystal Spring, } \\
\text { Pahranagat Valley, } \\
\text { Lincoln Co., NV }\end{array}$ & \\
\hline $\begin{array}{l}\text { Pyrgulopsis } \\
\text { imperialis }\end{array}$ & P140 & $\begin{array}{l}\text { AY379450 } \\
(P 140 A) \\
\text { AY426350 } \\
\text { (P140C) }\end{array}$ & 2 & $0.30 \%$ & & $\begin{array}{l}\text { P. cybele, differ } \\
\text { by } 3.7-3.7 \% \text {, } \\
\text { P. intermedia, } \\
\text { differ by } \\
3.3-4.0 \% \text {, } \\
\text { P. perforata, } \\
\text { differ by } \\
3.2-3.7 \% \text {, } \\
\text { P. robusta, differ } \\
\text { by } 3.4-4.1 \%\end{array}$ & $\begin{array}{l}\text { Spring, Thacker } \\
\text { Pass, Kings River } \\
\text { Valley, Humboldt } \\
\text { Co., NV }\end{array}$ & \\
\hline
\end{tabular}




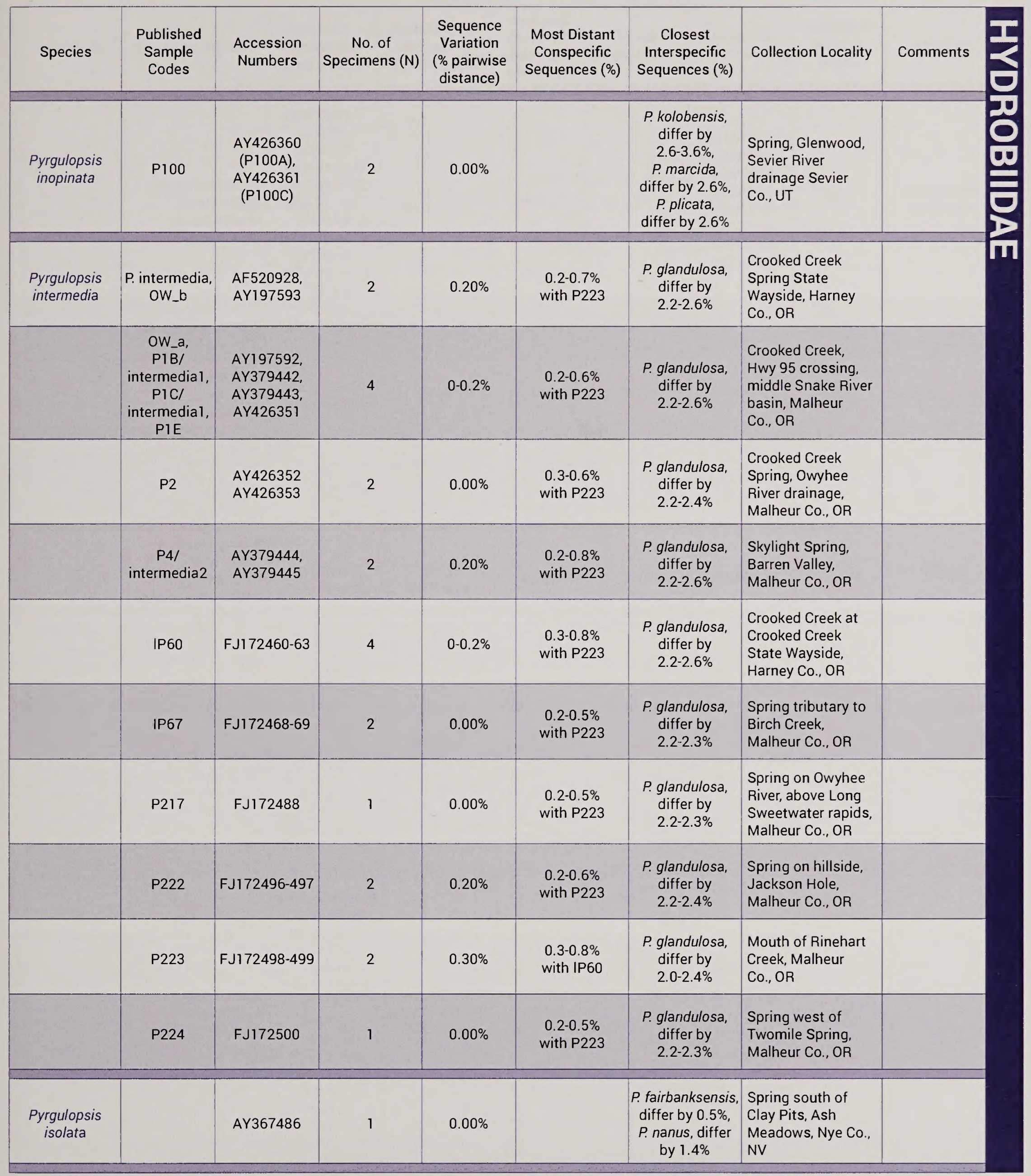




\begin{tabular}{|c|c|c|c|c|c|c|c|c|}
\hline Species & $\begin{array}{l}\text { Published } \\
\text { Sample } \\
\text { Codes }\end{array}$ & $\begin{array}{l}\text { Accession } \\
\text { Numbers }\end{array}$ & $\begin{array}{c}\text { No. of } \\
\text { Specimens }(\mathrm{N})\end{array}$ & $\begin{array}{l}\text { Sequence } \\
\text { Variation } \\
\text { (\% pairwise } \\
\text { distance) }\end{array}$ & $\begin{array}{c}\text { Most Distant } \\
\text { Conspecific } \\
\text { Sequences (\%) }\end{array}$ & $\begin{array}{c}\text { Closest } \\
\text { Interspecific } \\
\text { Sequences (\%) }\end{array}$ & Collection Locality & Comments \\
\hline \multirow[t]{8}{*}{$\begin{array}{l}\text { Pyrgulopsis } \\
\text { kolobensis }\end{array}$} & P162 & $\begin{array}{c}\text { AY379448 } \\
\text { (P162A), } \\
\text { AY379449 } \\
\text { (P162B), } \\
\text { AY379449 } \\
\text { (P162B), } \\
\text { AY426354 } \\
\text { (P162D) }\end{array}$ & 3 & $0.00 \%$ & $\begin{array}{l}3.1 \% \\
\text { with P193 }\end{array}$ & $\begin{array}{c}\text { P. pilsbryana, } \\
\text { differ by } \\
0.2-0.3 \% \text {, } \\
\text { P. transversa, } \\
\text { differ by } 1.1 \% \text {, } \\
\text { P. sp. C, differ } \\
\text { by } 0.3 \% \text {, } \\
\text { P. sp. D, differ } \\
\text { by } 0.2 \% \text {, } \\
\text { P. sp. } \mathrm{H}, \text { differ } \\
\text { by } 0.3 \%\end{array}$ & $\begin{array}{l}\text { Big Malad Spring, } \\
\text { Malad Valley, } \\
\text { Oneida Co., ID }\end{array}$ & \\
\hline & P117 & $\begin{array}{c}\text { AY627939 } \\
(\text { Tq3, P117A) }\end{array}$ & 1 & $0.00 \%$ & $2.9 \%$ with P162 & $\begin{array}{c}\text { P. variegata, } \\
\text { differ by } 1.9 \%\end{array}$ & $\begin{array}{l}\text { Toquerville Springs, } \\
\text { Washington Co., UT }\end{array}$ & \\
\hline & P193 & DQ364008 & 1 & $0.00 \%$ & $3.1 \%$ with P162 & $\begin{array}{l}\text { P. variegata, } \\
\text { differ by } 1.9 \%\end{array}$ & $\begin{array}{l}\text { Spring southwest } \\
\text { of Pinto, } \\
\text { Washington Co., UT }\end{array}$ & \\
\hline & P194 & DQ364009 & 1 & $0.00 \%$ & $\begin{array}{l}1.9 \% \text { with Kol3, } \\
\text { Kol4, P162, } 1.7- \\
1.9 \% \text { with Kol5 }\end{array}$ & $\begin{array}{l}\text { P. variegata, } \\
\text { differ by } 1.1 \%\end{array}$ & $\begin{array}{l}\text { Spring, Left Fork } \\
\text { Santa Clara } \\
\text { River, Pine Valley } \\
\text { campground, } \\
\text { Washington Co., UT }\end{array}$ & \\
\hline & P195 & DQ364010 & 1 & $0.00 \%$ & $\begin{array}{c}2.6 \% \\
\text { with P162 }\end{array}$ & $\begin{array}{l}P . \text { variegata, } \\
\text { differ by } 1.6 \%\end{array}$ & $\begin{array}{l}\text { Spring, Meadow } \\
\text { Valley Wash, } \\
\text { Kershaw-Ryan } \\
\text { State Park, Lincoln } \\
\text { Co., NV }\end{array}$ & \\
\hline & Kol1 & $\begin{array}{c}\text { KT248032 } \\
(\text { Kol1A, N=4), } \\
\text { KT248033 } \\
(\text { Kol1B, N=1) }\end{array}$ & 5 & $0-0.8 \%$ & $\begin{array}{l}2.3-2.8 \% \\
\text { with P193 }\end{array}$ & $\begin{array}{l}\text { P. nonaria, differ } \\
\text { by } 0.6-1.1 \% \text {, } \\
\text { P. pilsbryana, } \\
\text { differ by } \\
0.0-0.9 \% \text {, } \\
\text { P. transversa, } \\
\text { differ by } \\
0.8-1.0 \% \text {, } \\
\text { P. sp. C, differ } \\
\text { by } 0.2-1.0 \% \text {, } \\
\text { P. sp. D. differ } \\
\text { by } 0.0-0.8 \% \text {, } \\
\text { P. sp. } \mathrm{H}, \text { differ } \\
\text { by } 0.2-0.9 \%\end{array}$ & $\begin{array}{l}\text { Spring, Right Fork } \\
\text { Hobble Creek, Utah } \\
\text { Co., UT }\end{array}$ & \\
\hline & Kol2 & $\begin{array}{c}\text { KT248034 } \\
(\text { Kol2A, N=1), } \\
\text { KT248035 } \\
(\text { Kol2B, N=3), } \\
\text { KT248036 } \\
(\text { Kol2E, } N=1)\end{array}$ & 5 & $0-0.3 \%$ & $\begin{array}{c}2.0-2.2 \% \text { with } \\
\text { P117, 2.0-2.3\% } \\
\text { with P193 }\end{array}$ & $\begin{array}{l}\text { P. nonaria, differ } \\
\text { by } 0.5-0.6 \% \text {, } \\
\text { P. pilsbryana, } \\
\text { differ by } \\
0.6-0.9 \% \text {, } \\
\text { P. transversa, } \\
\text { differ by } \\
0.6-0.8 \% \text {, } \\
\text { P. sp. C, differ } \\
\text { by } 0.8-1.0 \% \text {, } \\
\text { P. sp. D, differ } \\
\text { by } 0.6-0.8 \% \text {, } \\
\text { P. sp. H, differ } \\
\text { by } 0 .-8-0.9 \%\end{array}$ & $\begin{array}{l}\text { Spring Creek, } \\
\text { Wallsburg, } \\
\text { Wasatch Co., UT }\end{array}$ & \\
\hline & Kol3 & $\begin{array}{c}\text { KT248037 } \\
(\text { Kol3A, N=5) }\end{array}$ & 5 & $0.00 \%$ & $\begin{array}{l}3.0 \% \\
\text { with P193 }\end{array}$ & $\begin{array}{l}\text { P. pilsbryana, } \\
\text { differ by } \\
0.2-0.3 \% \text {, } \\
\text { P. transversa, } \\
\text { differ by } 1.1 \% \text {, } \\
\text { P. sp. C, differ } \\
\text { by } 0.3 \% \text {, } \\
\text { P. sp. D, differ } \\
\text { by } 0.2 \% \text {, } \\
\text { P. sp. H, differ } \\
\text { by } 0.3 \%\end{array}$ & $\begin{array}{l}\text { Willow Creek, } \\
\text { Wasatch Co., UT }\end{array}$ & \\
\hline
\end{tabular}




\begin{tabular}{|c|c|c|c|c|c|c|c|c|}
\hline Species & $\begin{array}{l}\text { Published } \\
\text { Sample } \\
\text { Codes }\end{array}$ & $\begin{array}{l}\text { Accession } \\
\text { Numbers }\end{array}$ & $\begin{array}{c}\text { No. of } \\
\text { Specimens }(\mathrm{N})\end{array}$ & $\begin{array}{l}\text { Sequence } \\
\text { Variation } \\
\text { (\% pairwise } \\
\text { distance) }\end{array}$ & $\begin{array}{l}\text { Most Distant } \\
\text { Conspecific } \\
\text { Sequences (\%) }\end{array}$ & $\begin{array}{c}\text { Closest } \\
\text { Interspecific } \\
\text { Sequences (\%) }\end{array}$ & Collection Locality & Comments \\
\hline \multirow[t]{3}{*}{$\begin{array}{l}\text { Pyrgulopsis } \\
\text { kolobensis } \\
\text { (continued) }\end{array}$} & Kol4 & $\begin{array}{l}\text { KT248038 } \\
(\text { Kol4A, N =5) }\end{array}$ & 5 & $0.00 \%$ & $\begin{array}{l}2.2-2.9 \% \\
\text { with } \\
\text { Pkoll/Pkol2, } \\
2.6 \% \\
\text { with } \\
\text { P117, } \\
\text { P193 }\end{array}$ & $\begin{array}{l}\text { P. pilsbryana, } \\
\text { differ by } \\
0.2-0.3 \% \text {, } \\
\text { P. transversa, } \\
\text { differ by } 1.1 \% \text {, } \\
\text { P. sp. C, differ } \\
\text { by } 0.3 \% \text {, } \\
\text { P. sp. D, differ } \\
\text { by } 0.2 \% \text {, } \\
\text { P. sp. H, differ } \\
\text { by } 0.3 \%\end{array}$ & $\begin{array}{l}\text { Spring at Peoa, } \\
\text { Summit Co., UT }\end{array}$ & \\
\hline & Kol5 & $\begin{array}{c}\text { KT248039 } \\
(\text { Kol5A, N=2), } \\
\text { KT248040 } \\
(\text { Kol5B, N=1), } \\
\text { KT248041 } \\
(\text { Kol5C, N }=1) \\
\text { KT248042 } \\
(\text { Kol5D, N=1) }\end{array}$ & 5 & $0-0.5 \%$ & $\begin{array}{c}2.1-3.1 \% \\
\text { with } \\
\text { Pkol1 } / \text { Pkol2, } \\
2.6-2.8 \% \\
\text { with P117, } \\
2.5-2.8 \% \\
\text { with P193 }\end{array}$ & $\begin{array}{c}\text { P. pilsbryana, } \\
\text { differ by } \\
0.0-0.5 \% \text {, } \\
\text { P. transversa, } \\
\text { differ by } \\
1.0-1.3 \% \text {, } \\
\text { P. sp. C, differ } \\
\text { by } 0.2-0.5 \% \text {, } \\
\text { P. sp. D, differ } \\
\text { by } 0.0-0.3 \% \text {, } \\
\text { P. sp. } \mathrm{H}, \text { differ } \\
\text { by } 0.2-0.5 \%\end{array}$ & $\begin{array}{l}\text { Spring southwest } \\
\text { of Francis, Summit } \\
\text { Co., UT }\end{array}$ & \\
\hline & $\begin{array}{l}\text { Pkol1, } \\
\text { Pkol2 }\end{array}$ & $\begin{array}{c}\text { AY 485532 } \\
\text { (Pkol1, N=29), } \\
\text { AY485533 } \\
(\text { Pkol2, N=4) }\end{array}$ & 33 & $0-0.2 \%$ & $\begin{array}{c}2.5-3.1 \% \\
\text { with P162 }\end{array}$ & $\begin{array}{l}\text { P. variegata, } \\
\text { differ by } \\
1.6-2.1 \%\end{array}$ & Toquerville & Hurt (2004) \\
\hline $\begin{array}{c}\text { Pyrgulopsis } \\
\text { landyei }\end{array}$ & P68A & AY627930 & 1 & $0.00 \%$ & & $\begin{array}{l}\text { P. sulcata, } \\
\text { differ by } 3.7 \%\end{array}$ & $\begin{array}{l}\text { Middle Spring, } \\
\text { Steptoe Ranch, } \\
\text { Steptoe Valley, } \\
\text { White Pine Co., NV }\end{array}$ & \\
\hline \multirow[t]{2}{*}{$\begin{array}{l}\text { Pyrgulopsis } \\
\text { lasseni }\end{array}$} & WC_a & AY197604 & 1 & $0.00 \%$ & $\begin{array}{c}0.3 \% \\
\text { with WC_a }\end{array}$ & $\begin{array}{l}\text { P. eremica, differ } \\
\text { by } 0.3-6.8 \% \text {, } \\
\text { P. kolobensis, } \\
\text { differ by } \\
4.4-5.7 \% \text {, } \\
\text { P. pilsbryana, } \\
\text { differ by } \\
4.8-4.9 \% \text {, } \\
\text { P. transversa, } \\
\text { differ by } 4.8 \% \text {, } \\
\text { P. sp. D, differ } \\
\text { by } 4.8 \%\end{array}$ & $\begin{array}{l}\text { Willow Creek west } \\
\text { of Lower McBride } \\
\text { Springs, Lassen } \\
\text { Co., CA }\end{array}$ & \\
\hline & WC_b & AY 197605 & 1 & $0.00 \%$ & $\begin{array}{c}0.3 \% \\
\text { with WC_b }\end{array}$ & $\begin{array}{l}\text { P. eremica, differ } \\
\text { by } 0.3-6.8 \% \text {, } \\
\text { P. kolobensis, } \\
\text { differ by } \\
4.8-6.0 \%, \\
\text { P. pilsbryana, } \\
\text { differ by } \\
5.1-5.3 \% \\
\text { P. transversa, } \\
\text { differ by } 5.1 \% \text {, } \\
\text { P. sp. D, } \\
\text { differ by } 5.1 \%\end{array}$ & $\begin{array}{l}\text { Willow Creek } \\
\text { downstream from } \\
\text { Willow Creek } \\
\text { Campground, } \\
\text { Lassen Co., CA }\end{array}$ & \\
\hline
\end{tabular}




\begin{tabular}{|c|c|c|c|c|c|c|c|c|}
\hline Species & $\begin{array}{l}\text { Published } \\
\text { Sample } \\
\text { Codes }\end{array}$ & $\begin{array}{l}\text { Accession } \\
\text { Numbers }\end{array}$ & $\begin{array}{c}\text { No. of } \\
\text { Specimens }(\mathrm{N})\end{array}$ & $\begin{array}{l}\text { Sequence } \\
\text { Variation } \\
\text { (\% pairwise } \\
\text { distance) }\end{array}$ & $\begin{array}{l}\text { Most Distant } \\
\text { Conspecific } \\
\text { Sequences (\%) }\end{array}$ & $\begin{array}{c}\text { Closest } \\
\text { Interspecific } \\
\text { Sequences (\%) }\end{array}$ & Collection Locality & Comments \\
\hline $\begin{array}{l}\text { Pyrgulopsis } \\
\text { lata }\end{array}$ & P61B & AY627927 & 1 & $0.00 \%$ & & $\begin{array}{c}\text { P. breviloba, } \\
\text { differ by } 0.5 \% \text {, } \\
\text { P. kolobensis, } \\
\text { differ by } \\
3.9-5.2 \% \text {, } \\
P . \text { marcida, } \\
\text { differ by } 4.2 \% \text {, } \\
\text { P. nonaria, } \\
\text { differ by } 4.2 \%\end{array}$ & $\begin{array}{l}\text { Butterfield Springs, } \\
\text { White River Valley, } \\
\text { Nye Co., NV }\end{array}$ & \\
\hline $\begin{array}{l}\text { Pyrgulopsis } \\
\text { lentiglans }\end{array}$ & P103A & AY627936 & 1 & $0.00 \%$ & & $\begin{array}{l}\text { P. millenaria, } \\
\text { differ by } 1.6 \%\end{array}$ & $\begin{array}{l}\text { Crittenden Springs, } \\
\text { Thousand Springs } \\
\text { Creek drainage, } \\
\text { Elko Co., NV }\end{array}$ & \\
\hline $\begin{array}{l}\text { Pyrgulopsis } \\
\text { leporina }\end{array}$ & P123A & EU700471 & 1 & $0.00 \%$ & & $\begin{array}{c}\text { P. sublata, differ } \\
\text { by } 1.9 \%\end{array}$ & $\begin{array}{l}\text { Springs along } \\
\text { Rabbit Creek, } \\
\text { Humboldt River } \\
\text { drainage, Elko Co., } \\
\text { NV }\end{array}$ & \\
\hline \multirow[t]{6}{*}{$\begin{array}{l}\text { Pyrgulopsis } \\
\text { licina }\end{array}$} & M7 & $\begin{array}{l}\text { AY367438 } \\
(M 7 A) \\
\text { AY367439 } \\
\text { (M7B) }\end{array}$ & 2 & $0.20 \%$ & $\begin{array}{l}0.6-0.8 \% \\
\text { with } M 29\end{array}$ & $\begin{array}{l}\text { P. bifurcata, } \\
\text { differ by } \\
3.5-3.7 \%\end{array}$ & $\begin{array}{l}\text { Last Chance Spring, } \\
\text { Ash Meadows, Nye } \\
\text { Co., NV }\end{array}$ & $\begin{array}{l}\text { P. micrococcus } \\
\text { in GenBank }\end{array}$ \\
\hline & M29 & AY367476 & 1 & $0.00 \%$ & $\begin{array}{l}0.6-0.8 \% \\
\text { with } M 7\end{array}$ & $\begin{array}{l}\text { P. bifurcata, } \\
\text { differ by } 3.8 \%\end{array}$ & $\begin{array}{l}\text { Spring east of } \\
\text { Crystal Reservoir, } \\
\text { Ash Meadows, Nye } \\
\text { Co., NV }\end{array}$ & $\begin{array}{l}\text { P. micrococcus } \\
\text { in GenBank }\end{array}$ \\
\hline & M30 & $\begin{array}{c}\text { AY367477 } \\
\text { (M30A, M30C) }\end{array}$ & 2 & $0.00 \%$ & $\begin{array}{l}0.5-0.6 \% \\
\text { with } M 7\end{array}$ & $\begin{array}{l}\text { P. bifurcata, } \\
\text { differ by } 3.7 \%\end{array}$ & $\begin{array}{l}\text { Spring south of } \\
\text { Clay Pits, Ash } \\
\text { Meadows, Nye Co., } \\
\text { NV }\end{array}$ & $\begin{array}{l}\text { P. micrococcus } \\
\text { in GenBank }\end{array}$ \\
\hline & M52 & KF559189 & 2 & $0.00 \%$ & $\begin{array}{l}0.5-0.6 \% \\
\text { with } M 7\end{array}$ & $\begin{array}{l}\text { P. bifurcata, } \\
\text { differ by } 3.7 \%\end{array}$ & $\begin{array}{l}\text { Spring ca. } 100 \mathrm{~m} \\
\text { north of Collins } \\
\text { Ranch, Ash } \\
\text { Meadows, Nye Co., } \\
\text { NV }\end{array}$ & $\begin{array}{l}\text { P. perforata in } \\
\text { GenBank }\end{array}$ \\
\hline & M54 & KF559190 & 3 & $0.00 \%$ & $\begin{array}{l}0.5-0.6 \% \\
\text { with } \mathrm{M} 7\end{array}$ & $\begin{array}{l}\text { P. bifurcata, } \\
\text { differ by } 3.7 \%\end{array}$ & $\begin{array}{l}\text { Spring south of } \\
\text { Rogers Spring, Ash } \\
\text { Meadows, Nye Co., } \\
\text { NV }\end{array}$ & $\begin{array}{l}\text { P. perforata in } \\
\text { GenBank }\end{array}$ \\
\hline & M58 & KF559191 & 2 & $0.00 \%$ & $\begin{array}{l}0.5-0.6 \% \\
\text { with } \mathrm{M} 7\end{array}$ & $\begin{array}{l}\text { P. bifurcata, } \\
\text { differ by } 3.7 \%\end{array}$ & $\begin{array}{l}\text { Spring east of } \\
\text { Crystal Reservoir, } \\
\text { Ash Meadows, Nye } \\
\text { Co., NV }\end{array}$ & $\begin{array}{l}\text { P. perforata in } \\
\text { GenBank }\end{array}$ \\
\hline \multirow[t]{3}{*}{$\begin{array}{c}\text { Pyrqulopsis } \\
\text { limaria }\end{array}$} & SM2 & EF119088-92 & 6 & $0-0.9 \%$ & $\begin{array}{c}0.3-1.5 \% \text { with } \\
\text { SM10, 0.2-1.4\% } \\
\text { with SM22 }\end{array}$ & $\begin{array}{l}\text { P. umbilicata, } \\
\text { differ by } \\
0.2-0.9 \%\end{array}$ & $\begin{array}{l}\text { Spring brook, } \\
\text { western Soldier } \\
\text { Meadow, Humboldt } \\
\text { Co., NV }\end{array}$ & \\
\hline & SM7 & EF119095-97 & 5 & $0-0.3 \%$ & $\begin{array}{c}0.5-1.1 \% \text { with } \\
\text { SM10 }\end{array}$ & $\begin{array}{l}\text { P. umbilicata, } \\
\text { differ by } \\
0.2-0.5 \%\end{array}$ & $\begin{array}{l}\text { Spring } 150 \mathrm{~m} \mathrm{~W} \\
\text { of Satellite Spring, } \\
\text { Humboldt Co., NV }\end{array}$ & \\
\hline & SM10 & EF1 19098-100 & 5 & $0-0.3 \%$ & $\begin{array}{c}0.3-1.2 \% \\
\text { with SM23, } \\
\text { SM36, 0.3-1.1\% } \\
\text { with SM24, } \\
\text { SM } 26, \\
\text { SM29/31, } \\
0.3-1.4 \% \text { with } \\
\text { SM2, } 0.5-1.1 \% \\
\text { with SM7 }\end{array}$ & $\begin{array}{l}\text { P. umbilicata, } \\
\text { differ by } \\
0.6-1.2 \%\end{array}$ & $\begin{array}{l}\text { Tole Spring, } \\
\text { western Soldier } \\
\text { Meadow, } \\
\text { Humboldt Co., NV }\end{array}$ & \\
\hline
\end{tabular}




\begin{tabular}{|c|c|c|c|c|c|c|c|c|}
\hline Species & $\begin{array}{l}\text { Published } \\
\text { Sample } \\
\text { Codes }\end{array}$ & $\begin{array}{l}\text { Accession } \\
\text { Numbers }\end{array}$ & $\begin{array}{c}\text { No. of } \\
\text { Specimens }(\mathrm{N})\end{array}$ & $\begin{array}{l}\text { Sequence } \\
\text { Variation } \\
\text { (\% pairwise } \\
\text { distance) }\end{array}$ & $\begin{array}{l}\text { Most Distant } \\
\text { Conspecific } \\
\text { Sequences (\%) }\end{array}$ & $\begin{array}{c}\text { Closest } \\
\text { Interspecific } \\
\text { Sequences (\%) }\end{array}$ & Collection Locality & Comments \\
\hline \multirow[t]{7}{*}{$\begin{array}{l}\text { Pyrgulopsis } \\
\text { limaria } \\
\text { (continued) }\end{array}$} & SM22 & EF119106-110 & 5 & $0.2-0.6 \%$ & $\begin{array}{c}0.2-1.1 \% \text { with } \\
\text { SM23, SM36, } \\
0.3-1.1 \% \\
\text { with SM26, } \\
0.2-1.4 \% \\
\text { with SM2 }\end{array}$ & $\begin{array}{l}\text { P. umbilicata, } \\
\text { differ by } \\
0.5-1.1 \%\end{array}$ & $\begin{array}{l}\text { Tole Spring } 30 \mathrm{~m} \\
\text { downflow from } \\
\text { source, western } \\
\text { Soldier Meadow, } \\
\text { Humboldt Co., NV }\end{array}$ & \\
\hline & SM23 & EF119111-114 & 4 & $0.2-0.6 \%$ & $\begin{array}{c}0.3-1.2 \% \text { with } \\
\text { SM10, 0.2-1.1\% } \\
\text { with SM } 22\end{array}$ & $\begin{array}{l}\text { P. umbilicata, } \\
\text { differ by } \\
0.2-0.6 \%\end{array}$ & $\begin{array}{l}\text { Satellite Spring } \\
\text { complex, spring "A." } \\
60+m \text { downflow } \\
\text { from source, } \\
\text { Humboldt Co., NV }\end{array}$ & \\
\hline & SM24 & EF119115-116 & 4 & $0.50 \%$ & $\begin{array}{l}0.3-1.1 \% \text { with } \\
\text { SM10 }\end{array}$ & $\begin{array}{l}\text { P. umbilicata, } \\
\text { differ by } \\
0.2-0.6 \%\end{array}$ & $\begin{array}{l}\text { Satellite Spring } \\
\text { complex, spring "B," } \\
\text { Humboldt Co., NV }\end{array}$ & \\
\hline & SM26 & EF1 19117-120 & 4 & $0.3-0.6 \%$ & $\begin{array}{c}0.0-1.1 \% \text { with } \\
\text { SM2, 0.3-1.1\% } \\
\text { with SM10, } \\
\text { SM22 }\end{array}$ & $\begin{array}{l}\text { P. umbilicata, } \\
\text { differ by } \\
0.2-0.8 \%\end{array}$ & $\begin{array}{l}\text { Satellite Spring } \\
\text { complex, spring "F," } \\
\text { Humboldt Co., NV }\end{array}$ & \\
\hline & $\begin{array}{c}\text { SM29, } \\
31\end{array}$ & EF1 19121-123 & 7 & $0-0.5 \%$ & $\begin{array}{l}0.3-1.1 \% \text { with } \\
\text { SM } 10\end{array}$ & $\begin{array}{l}\text { P. umbilicata, } \\
\text { differ by } \\
0.2-0.6 \%\end{array}$ & $\begin{array}{l}\text { Satellite Spring } \\
\text { complex, spring "H," } \\
\text { Humboldt Co., NV }\end{array}$ & \\
\hline & SM34 & EF1 190124 & 2 & $0.00 \%$ & $\begin{array}{c}0.0-0.9 \% \text { with } \\
\text { SM2 }\end{array}$ & $\begin{array}{l}\text { P. umbilicata, } \\
\text { differ by } \\
0.3-0.6 \%\end{array}$ & $\begin{array}{l}\text { Satellite Spring } \\
\text { complex, spring "J," } \\
\text { Humboldt Co., NV }\end{array}$ & \\
\hline & SM36 & EF119125-126 & 5 & $0-0.6 \%$ & $\begin{array}{c}0.3-1.2 \% \text { with } \\
\text { SM10,0.2-1.1\% } \\
\text { with SM } 22\end{array}$ & $\begin{array}{l}\text { P. umbilicata, } \\
\text { differ by } \\
0.3-0.6 \%\end{array}$ & $\begin{array}{l}\text { Satellite Spring } 200 \\
\text { m downflow from } \\
\text { source, Humboldt } \\
\text { Co., NV }\end{array}$ & \\
\hline $\begin{array}{l}\text { Pyrgulopsis } \\
\text { lindae }\end{array}$ & 17/P24 & GQ275091 & 4 & $0.00 \%$ & & $\begin{array}{l}\text { P. kolobensis, } \\
\text { differ by } \\
5.6-7.8 \% \text {, } \\
\text { P. pilsbryana, } \\
\text { differ by } 6.0 \% \text {, } \\
\text { P. sp. C, differ } \\
\text { by } 5.9-6.1 \% \text {, } \\
\text { P. sp. C. differ } \\
\text { by } 5.9-6.1 \% \text {, } \\
\text { P. sp. D, differ } \\
\text { by } 6.0 \%\end{array}$ & $\begin{array}{l}\text { San Domingo Creek, } \\
\text { San Joaquin River } \\
\text { basin, Calaveras } \\
\text { Co., CA }\end{array}$ & $\begin{array}{l}\text { P. sp. } \\
\text { USNM905258 } \\
\text { isolate } \\
\text { P24AA in } \\
\text { GenBank, } \\
\text { described as } \\
\text { P. lindae in } \\
\text { Hershler et al. } \\
(2016 b)\end{array}$ \\
\hline $\begin{array}{l}\text { Pyrgulopsis } \\
\text { lockensis }\end{array}$ & P82D & AY627932 & 1 & $0.00 \%$ & & $\begin{array}{l}\text { P. villacampae, } \\
\text { differ by } 2.6 \%\end{array}$ & $\begin{array}{l}\text { Big Spring, Lockes } \\
\text { Ranch, Railroad } \\
\text { Valley, Nye Co., NV }\end{array}$ & \\
\hline $\begin{array}{l}\text { Pyrgulopsis } \\
\text { longiglans }\end{array}$ & P133A & $\begin{array}{l}\text { EF119141, } \\
\text { DQ364017 }\end{array}$ & 1 & $0.00 \%$ & & $\begin{array}{c}\text { P. kolobensis, } \\
\text { differ by } \\
4.5-5.9 \% \text {, } \\
\text { P. variegata, } \\
\text { differ by } 5.0 \%\end{array}$ & $\begin{array}{l}\text { Spring NNW of } \\
\text { Holbrook Junction, } \\
\text { Antelope Valley, } \\
\text { Douglas Co., NV }\end{array}$ & $\begin{array}{l}\text { DQ364017: } \\
\text { P. sp. Virginia } \\
\text { HPL-2006 in } \\
\text { GenBank }\end{array}$ \\
\hline $\begin{array}{l}\text { Pyrgulopsis } \\
\text { longinqua }\end{array}$ & P32B & DQ364006 & 1 & $0.00 \%$ & & \begin{tabular}{|} 
P. californiensis, \\
differ by \\
$2.4-7.9 \%$, \\
P. montana, \\
differ by $2.9 \%$
\end{tabular} & $\begin{array}{l}\text { Spring west- } \\
\text { southwest of } \\
\text { Hunters Spring, } \\
\text { Salton Sea basin, } \\
\text { Riverside Co., CA }\end{array}$ & \\
\hline
\end{tabular}




\begin{tabular}{|c|c|c|c|c|c|c|c|c|}
\hline Species & $\begin{array}{l}\text { Published } \\
\text { Sample } \\
\text { Codes }\end{array}$ & $\begin{array}{l}\text { Accession } \\
\text { Numbers }\end{array}$ & $\begin{array}{c}\text { No. of } \\
\text { Specimens }(\mathrm{N})\end{array}$ & $\begin{array}{c}\text { Sequence } \\
\text { Variation } \\
\text { (\% pairwise } \\
\text { distance) }\end{array}$ & $\begin{array}{l}\text { Most Distant } \\
\text { Conspecific } \\
\text { Sequences (\%) }\end{array}$ & $\begin{array}{c}\text { Closest } \\
\text { Interspecific } \\
\text { Sequences (\%) }\end{array}$ & Collection Locality & Comments \\
\hline $\begin{array}{l}\text { Pyrgulopsis } \\
\text { marcida }\end{array}$ & P59A & DQ364012 & 1 & $0.00 \%$ & & $\begin{array}{c}\text { P. kolobensis, } \\
\text { differ by } \\
1.1-2.7 \% \text {, } \\
\text { P. serrata, } \\
\text { differ by } 1.4 \% \text {, } \\
\text { P. sterilis, differ } \\
\text { by } 1.4 \% \text {, } \\
\text { P. variegata, } \\
\text { differ by } 1.4 \%\end{array}$ & $\begin{array}{l}\text { Hardy Springs, } \\
\text { White River Valley, } \\
\text { Nye Co., NV }\end{array}$ & \\
\hline \multirow[t]{2}{*}{$\begin{array}{l}\text { Pyrgulopsis } \\
\text { marilynae }\end{array}$} & G8 & $\begin{array}{c}\text { KC571299 } \\
(N=1) \\
\text { KC571300 } \\
(N=1) \\
\text { KC571301 } \\
(N=3) \\
\text { KC571302 } \\
(N=1)\end{array}$ & 6 & $0-0.3 \%$ & $\begin{array}{l}0.2-0.3 \% \\
\text { with G11 }\end{array}$ & $\begin{array}{l}\text { P. gilae, } \\
\text { differ by } \\
3.2-4.0 \%\end{array}$ & $\begin{array}{l}\text { Spring along } \\
\text { Middle Fork Gila } \\
\text { River, ca. } 0.97 \mathrm{~km} \\
\text { north, } 0.64 \mathrm{~km} \\
\text { west of Jordan } \\
\text { Canyon, Grant Co., } \\
\text { NM }\end{array}$ & $\begin{array}{l}P . \text { gilae in } \\
\text { GenBank }\end{array}$ \\
\hline & G11 & KC571305 & 2 & $0.00 \%$ & $\begin{array}{l}0.2-0.3 \% \\
\text { with G8 }\end{array}$ & $\begin{array}{l}\text { P. gilae, } \\
\text { differ by } \\
3.4-4.0 \%\end{array}$ & $\begin{array}{l}\text { Spring along Middle } \\
\text { Fork Gila River, ca. } \\
0.48 \mathrm{~km} \text { north, } \\
0.48 \mathrm{~km} \text { west of } \\
\text { Jordan Canyon, } \\
\text { Grant Co., NM }\end{array}$ & $\begin{array}{l}\text { P. gilae in } \\
\text { GenBank }\end{array}$ \\
\hline $\begin{array}{l}\text { Pyrgulopsis } \\
\text { merriami }\end{array}$ & P8B & AY627919 & 1 & $0.00 \%$ & & $\begin{array}{l}\text { P. notidicola, } \\
\text { differ by } \\
8.4-9.7 \% \\
\text { P. trivialis, differ } \\
\text { by } 8.6-8.9 \% \text {, }\end{array}$ & $\begin{array}{l}\text { Ash Spring, } \\
\text { Pahranagat Valley } \\
\text { Lincoln Co., NV }\end{array}$ & \\
\hline \multirow[t]{2}{*}{$\begin{array}{l}\text { Pyrgulopsis } \\
\text { micrococcus }\end{array}$} & M1 & $\begin{array}{c}\text { AF520944/ } \\
\text { AY367415-417/ } \\
\text { AY367420/ } \\
\text { AY367424/ } \\
\text { AY367427-28 } \\
(\mathrm{N}=8, \mathrm{M} 1 \mathrm{~A}-1 \mathrm{D}, \\
\text { G, K, N-O), } \\
\text { AY367418-19 } \\
(\mathrm{N}=2, \mathrm{M} 1 \mathrm{E}-\mathrm{F}) \text {, } \\
\text { AY367421-23/ } \\
\text { AY367425-26/ } \\
\text { AY367429 } \\
(\mathrm{N}=6, \mathrm{M} 1 \mathrm{H}-\mathrm{J}, \\
\text { L-M, P) }\end{array}$ & 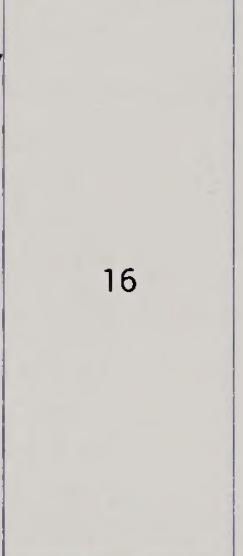 & $0-0.6 \%$ & $\begin{array}{l}0.0-0.3 \% \\
\text { with M31 }\end{array}$ & $\begin{array}{l}\text { P. perforata, } \\
\text { differ by } \\
3.9-4.5 \%\end{array}$ & $\begin{array}{l}\text { AF520944: } \\
\text { Spring just S of } \\
\text { Springdale, Nye } \\
\text { Co., NV } \\
\text { AY367418-29: } \\
\text { Spring, Fleur de } \\
\text { Lis Ranch, Oasis } \\
\text { Valley, Nye Co., NV }\end{array}$ & \\
\hline & M31 & AY 367478 & 1 & $0.00 \%$ & $\begin{array}{l}0.0-0.3 \% \\
\text { with } \mathrm{M} 1\end{array}$ & $\begin{array}{l}\text { P. perforata, } \\
\text { differ by } \\
3.9-4.3 \%\end{array}$ & $\begin{array}{l}\text { Goss Springs, } \\
\text { Oasis Valley, Nye } \\
\text { Co., NV }\end{array}$ & \\
\hline \multirow[t]{2}{*}{$\begin{array}{l}\text { Pyrgulopsis } \\
\text { militaris }\end{array}$} & $\begin{array}{l}\text { SM/P147A, } \\
\text { P147C, } \\
\text { P147D, } \\
\text { P147E, } \\
\text { P147F }\end{array}$ & $\begin{array}{l}\text { AY197596, } \\
\text { AY426362, } \\
\text { EF119077, } \\
\text { EF119078, } \\
\text { EF119079 }\end{array}$ & 5 & $0.0-0.9 \%$ & $\begin{array}{r}1.5-2.2 \% \\
\text { with SM1 }\end{array}$ & $\begin{array}{l}\text { P. varneri, } \\
\text { differ by } \\
2.0-2.7 \%\end{array}$ & $\begin{array}{l}\text { Spring, Soldier } \\
\text { Meadow, Humboldt } \\
\text { Co., NV }\end{array}$ & \\
\hline & SM1 & EF119076 & 5 & $0.00 \%$ & $\begin{array}{c}1.5-2.2 \% \\
\text { with P147 }\end{array}$ & $\begin{array}{l}\text { P. varneri, differ } \\
\text { by } 2.3-2.7 \%\end{array}$ & $\begin{array}{l}\text { West Spring, Bog } \\
\text { Hot Valley, } \\
\text { Humboldt Co., NV }\end{array}$ & \\
\hline
\end{tabular}




\begin{tabular}{|c|c|c|c|c|c|c|c|c|}
\hline Species & $\begin{array}{l}\text { Published } \\
\text { Sample } \\
\text { Codes }\end{array}$ & $\begin{array}{l}\text { Accession } \\
\text { Numbers }\end{array}$ & $\begin{array}{c}\text { No. of } \\
\text { Specimens }(\mathrm{N})\end{array}$ & $\begin{array}{l}\text { Sequence } \\
\text { Variation } \\
\text { (\% pairwise } \\
\text { distance) }\end{array}$ & $\begin{array}{l}\text { Most Distant } \\
\text { Conspecific } \\
\text { Sequences (\%) }\end{array}$ & $\begin{array}{c}\text { Closest } \\
\text { Interspecific } \\
\text { Sequences (\%) }\end{array}$ & Collection Locality & Comments \\
\hline $\begin{array}{l}\text { Pyrgulopsis } \\
\text { millenaria }\end{array}$ & P104A & EU700469 & 1 & $0.00 \%$ & & $\begin{array}{l}\text { P. /entiglans, } \\
\text { differ by } 1.6 \%\end{array}$ & $\begin{array}{l}\text { Spring below } \\
\text { Twentyone Mile } \\
\text { Dam, Thousand } \\
\text { Springs Creek } \\
\text { drainage, Elko Co., } \\
\text { NV }\end{array}$ & \\
\hline $\begin{array}{l}\text { Pyrgulopsis } \\
\text { milleri }\end{array}$ & P23 & GQ275096 & 3 & $0.00 \%$ & & $\begin{array}{l}\text { P. glandulosa, } \\
\text { differ by } \\
2.8-3.3 \% \text {, } \\
\text { P. hualapaiensis, } \\
\text { differ by } 2.9 \% \text {, } \\
\text { P. perforata, } \\
\text { differ by } \\
2.8-2.9 \% \\
\text { P. thompsoni, } \\
\text { differ by } \\
2.7-3.4 \% \\
\text { P. torrida, differ } \\
\text { by } 2.8 \%\end{array}$ & $\begin{array}{l}\text { Pierpoint Spring, } \\
\text { Tulare-Buena Vista } \\
\text { Lakes drainage, } \\
\text { Tulare Co., CA }\end{array}$ & $\begin{array}{l}\text { Pyrgulopsis } \\
\text { sp. } 2 \\
\text { HPL2009 } \\
\text { isolate P23B } \\
\text { in GenBank }\end{array}$ \\
\hline $\begin{array}{l}\text { Pyrgulopsis } \\
\text { montana }\end{array}$ & P118A & AY627940 & 1 & $0.00 \%$ & & $\begin{array}{l}\text { P. bacchus, } \\
\text { differ by } \\
2.2-2.6 \%\end{array}$ & $\begin{array}{l}\text { Spring, upper Camp } \\
\text { Valley, Meadow } \\
\text { Valley Wash, Lincoln } \\
\text { Co., NV }\end{array}$ & \\
\hline $\begin{array}{c}\text { Pyrgulopsis } \\
\text { montezumensis }\end{array}$ & $\begin{array}{l}\text { Pmon1, } \\
\text { Pmon2 }\end{array}$ & $\begin{array}{c}\text { AY485552 } \\
\text { (Pmon1, N=33), } \\
\text { AY485553 } \\
(\text { Pmon } 2, N=1)\end{array}$ & 34 & $0.0-0.2 \%$ & & $\begin{array}{c}\text { P. glandulosa, } \\
\text { differ by } \\
3.3-3.8 \%, \\
\text { P. intermedia, } \\
\text { differ by } \\
3.6-4.1 \% \text {, } \\
\text { P. perforata, } \\
\text { differ by } \\
3.6-3.9 \% \\
\text { P. robusta, differ } \\
\text { by } 3.7-4.4 \%\end{array}$ & Montezuma Well & Hurt (2004) \\
\hline $\begin{array}{l}\text { Pyrgulopsis } \\
\text { morrisoni }\end{array}$ & P150 & DQ364007 & 1 & $0.00 \%$ & $\begin{array}{c}0.0-1.7 \% \text { with } \\
\text { Pmor } 1 / 2 / 3 / 4 \text {, } \\
0.5 \% \text { with } \\
\text { Pmor5 }\end{array}$ & $\begin{array}{l}\text { P. glandulosa, } \\
\text { differ by } \\
3.1-3.5 \%\end{array}$ & $\begin{array}{l}\text { Spring, Bubbling } \\
\text { Pond Hatchery, } \\
\text { Verde River basin, } \\
\text { Yavapai Co., AZ }\end{array}$ & \\
\hline e. & $\begin{array}{l}\text { Pmor1, } \\
\text { Pmor2, } \\
\text { Pmor3, } \\
\text { Pmor4 }\end{array}$ & $\begin{array}{c}\text { AY485547 } \\
\text { (Pmor1, N=12), } \\
\text { AY485548 } \\
(\mathrm{Pmor} 2, N=4), \\
\text { AY485549 } \\
(\mathrm{Pmor} 3, \mathrm{~N}=3) \\
\text { AY485550 } \\
(\mathrm{Pmor} 4, N=6)\end{array}$ & 26 & $0-1.7 \%$ & $\begin{array}{c}0.0-1.7 \% \text { with } \\
\text { P150, 0.2-1.5\% } \\
\text { with Pmor5 }\end{array}$ & $\begin{array}{l}\text { P. glandulosa, } \\
\text { differ by } \\
2.8-3.6 \%\end{array}$ & Bubbling & $\begin{array}{l}\text { Hurt (2004), } \\
\text { listed } \\
\text { frequency } \\
\text { only added } \\
\text { to } 0.961\end{array}$ \\
\hline & Pmor5 & AY185551 & 30 & $0.00 \%$ & $\begin{array}{c}0.5 \% \text { with P150, } \\
0.2-1.5 \% \text { with } \\
\text { Pmor } 1 / 2 / 3 / 4\end{array}$ & $\begin{array}{l}\text { P. glandulosa, } \\
\text { differ by } \\
3.3-3.6 \%\end{array}$ & Page & Hurt (2004) \\
\hline $\begin{array}{l}\text { Pyrgulopsis } \\
\text { nanus }\end{array}$ & & AY367487 & 1 & $0.00 \%$ & & $\begin{array}{c}\text { P. fairbanksensis, } \\
\text { differ by } 1.3 \% \text {, } \\
\text { P. isolata, } \\
\text { differ by } 1.4 \%\end{array}$ & $\begin{array}{l}\text { Five Springs, Ash } \\
\text { Meadows, Nye Co., } \\
\text { NV }\end{array}$ & \\
\hline $\begin{array}{l}\text { Pyrgulopsis } \\
\text { neritella }\end{array}$ & & AF520951 & 1 & $0.00 \%$ & & $\begin{array}{c}\text { P. sulcata, differ } \\
\text { by } 3.2 \%\end{array}$ & $\begin{array}{l}\text { Big Spring, Steptoe } \\
\text { Ranch, White Pine } \\
\text { Co., NV }\end{array}$ & \\
\hline
\end{tabular}




\begin{tabular}{|c|c|c|c|c|c|c|c|c|}
\hline Species & $\begin{array}{l}\text { Published } \\
\text { Sample } \\
\text { Codes }\end{array}$ & $\begin{array}{l}\text { Accession } \\
\text { Numbers }\end{array}$ & $\begin{array}{c}\text { No. of } \\
\text { Specimens }(\mathrm{N})\end{array}$ & $\begin{array}{l}\text { Sequence } \\
\text { Variation } \\
\text { (\% pairwise } \\
\text { distance) }\end{array}$ & $\begin{array}{c}\text { Most Distant } \\
\text { Conspecific } \\
\text { Sequences (\%) }\end{array}$ & $\begin{array}{c}\text { Closest } \\
\text { Interspecific } \\
\text { Sequences (\%) }\end{array}$ & Collection Locality & Comments \\
\hline $\begin{array}{l}\text { Pyrgulopsis } \\
\text { nonaria }\end{array}$ & P97B & EU700467 & 1 & $0.00 \%$ & & $\begin{array}{c}\text { P. kolobensis, } \\
\text { differ by } \\
0.5-2.5 \% \text {, } \\
\text { P. pilsbryana, } \\
\text { differ by } \\
1.1-1.2 \% \text {, } \\
\text { P. transversa, } \\
\text { differ by } 1.1 \% \text {, } \\
\text { P. sp. D, } \\
\text { differ by } 1.1 \%\end{array}$ & $\begin{array}{l}\text { Spring east of } \\
\text { Ninemile Reservoir, } \\
\text { Sevier River } \\
\text { drainage, Sanpete } \\
\text { Co., UT }\end{array}$ & \\
\hline \multirow[t]{8}{*}{$\begin{array}{l}\text { Pyrgulopsis } \\
\text { motidicola }\end{array}$} & SM6 & EF119128 & 4 & $0.00 \%$ & $\begin{array}{c}0-2.6 \% \\
\text { with SM } 35 \\
1.1 \% \\
\text { with SM9, } \\
\text { SM } 30\end{array}$ & $\begin{array}{l}\text { P. limaria, differ } \\
\text { by } 6.2-7.0 \% \text {, } \\
\text { P. umbilicata, } \\
\text { differ by } \\
6.4-6.5 \%\end{array}$ & $\begin{array}{l}\text { Satellite Spring, } \\
\text { western Soldier } \\
\text { Meadow, Humboldt } \\
\text { Co., NV }\end{array}$ & \\
\hline & SM9 & EF119132-33 & 5 & $0-0.3 \%$ & $\begin{array}{c}1.1-2.1 \% \\
\text { with SM35 }\end{array}$ & $\begin{array}{l}\text { P. limaria, differ } \\
\text { by } 5.8-7.1 \% \text {, } \\
\text { P. umbilicata, } \\
\text { differ by } \\
5.9-6.4 \%\end{array}$ & $\begin{array}{l}\text { Satellite Spring } \\
\text { complex, spring } \\
\text { brook, Humboldt } \\
\text { Co., NV }\end{array}$ & \\
\hline & SM27 & EF119134-35 & 4 & $0-0.5 \%$ & $\begin{array}{c}0.9-2.3 \% \\
\text { with SM35 }\end{array}$ & $\begin{array}{l}\text { P. limaria, differ } \\
\text { by } 5.9-7.1 \% \text {, } \\
\text { P. umbilicata, } \\
\text { differ by } \\
6.1-6.4 \%\end{array}$ & $\begin{array}{l}\text { Satellite Spring } \\
\text { complex, spring } \\
\text { brook, Humboldt } \\
\text { Co., NV }\end{array}$ & \\
\hline & SM30 & EF119136 & 3 & $0.00 \%$ & $\begin{array}{c}1.1-1.8 \% \\
\text { with SM35 }\end{array}$ & $\begin{array}{l}\text { P. limaria, differ } \\
\text { by } 6.1-7.1 \% \text {, } \\
\text { P. umbilicata, } \\
\text { differ by } \\
6.2-6.4 \%\end{array}$ & $\begin{array}{l}\text { Satellite Spring } \\
\text { complex, spring "H," } \\
\text { Humboldt Co., NV }\end{array}$ & \\
\hline & SM32 & EF119137-38 & 3 & $0-0.2 \%$ & $\begin{array}{c}0.9-2.0 \% \\
\text { with SM35 }\end{array}$ & $\begin{array}{l}\text { P. limaria, differ } \\
\text { by } 5.9-7.1 \% \text {, } \\
\text { P. umbilicata, } \\
\text { differ by } \\
6.1-6.4 \%\end{array}$ & $\begin{array}{l}\text { Satellite Spring } \\
\text { complex, spring "I," } \\
\text { Humboldt Co., NV }\end{array}$ & \\
\hline & SM33 & EF119139 & 5 & $0.00 \%$ & $\begin{array}{c}0.9-2.0 \% \\
\text { with SM35 }\end{array}$ & $\begin{array}{l}\text { P. limaria, differ } \\
\text { by } 5.9-7.0 \% \text {, } \\
\text { P. umbilicata, } \\
\text { differ by } \\
6.1-6.2 \%\end{array}$ & $\begin{array}{l}\text { Satellite Spring } \\
\text { complex, spring "J," } \\
\text { Humboldt Co., NV }\end{array}$ & \\
\hline & SM35 & $\begin{array}{c}\text { EF119129-30, } \\
\text { EF119140 }\end{array}$ & 5 & $0-2.7 \%$ & $\begin{array}{c}0.9-2.3 \% \text { with } \\
\text { SM27, } 1.1-2.1 \% \\
\text { with SM9, } \\
0-2.6 \% \text { with } \\
\text { SM6, } 0-2.2 \% \\
\text { with P146 }\end{array}$ & $\begin{array}{l}\text { P. limaria, differ } \\
\text { by } 6.1-7.1 \% \text {, } \\
\text { P. umbilicata, } \\
\text { differ by } \\
6.2-6.7 \%\end{array}$ & $\begin{array}{l}\text { Satellite Spring, } \\
\text { western Soldier } \\
\text { Meadow, Humboldt } \\
\text { Co., NV }\end{array}$ & \\
\hline & $\mathrm{P} 146$ & EF119131 & 1 & $0.00 \%$ & $\begin{array}{c}0-2.2 \% \text { with } \\
\text { SM } 35,1.0 \% \text { with } \\
\text { SM9, SM30 }\end{array}$ & $\begin{array}{l}\text { P. limaria, } \\
\text { differ by } \\
6.1-6.9 \%, \\
\text { P. umbilicata, } \\
\text { differ by } \\
6.3-6.4 \% \\
\end{array}$ & $\begin{array}{l}\text { Northernmost } \\
\text { spring of large } \\
\text { complex, western } \\
\text { Soldier Meadow, } \\
\text { Humboldt Co., NV }\end{array}$ & \\
\hline $\begin{array}{l}\text { Pyrgulopsis } \\
\text { ojaiensis }\end{array}$ & M56 & KF559192 & 3 & $0.00 \%$ & $\begin{array}{c}0.8 \% \\
\text { with P29 }\end{array}$ & $\begin{array}{c}\text { P. castaicensis, } \\
\text { differ by } 3.6 \% \text {, } \\
\text { P. glandulosa, } \\
\text { differ by } \\
3.7-4.4 \%\end{array}$ & $\begin{array}{l}\text { Grapevine Springs, } \\
\text { Death Valley, Inyo } \\
\text { Co., CA }\end{array}$ & $\begin{array}{l}\text { P. sp. M56 in } \\
\text { GenBank }\end{array}$ \\
\hline
\end{tabular}




\begin{tabular}{|c|c|c|c|c|c|c|c|c|}
\hline Species & $\begin{array}{c}\text { Published } \\
\text { Sample } \\
\text { Codes }\end{array}$ & $\begin{array}{l}\text { Accession } \\
\text { Numbers }\end{array}$ & $\begin{array}{c}\text { No. of } \\
\text { Specimens }(\mathrm{N})\end{array}$ & $\begin{array}{l}\text { Sequence } \\
\text { Variation } \\
\text { (\% pairwise } \\
\text { distance) }\end{array}$ & $\begin{array}{l}\text { Most Distant } \\
\text { Conspecific } \\
\text { Sequences (\%) }\end{array}$ & $\begin{array}{c}\text { Closest } \\
\text { Interspecific } \\
\text { Sequences (\%) }\end{array}$ & Collection Locality & Comments \\
\hline $\begin{array}{l}\text { Pyrgulopsis } \\
\text { ojaiensis } \\
\text { (continued) }\end{array}$ & P29 & GQ275093 & 4 & $0.00 \%$ & $\begin{array}{c}0.8 \% \\
\text { with M56 }\end{array}$ & $\begin{array}{l}\text { P. castaicensis, } \\
\text { differ by } 3.8 \% \text {, } \\
\text { P. glandulosa, } \\
\text { differ by } \\
3.5-4.3 \%\end{array}$ & $\begin{array}{l}\text { Spring tributary } \\
\text { to Sisar Creek, } \\
\text { Southern California } \\
\text { coastal drainage, } \\
\text { Ventura Co., CA }\end{array}$ & $\begin{array}{l}\text { P. sp. } \\
\text { USNM905259 } \\
\text { isolate P29A } \\
\text { in GenBank, } \\
\text { placed under } \\
\text { P. stearnsiana } \\
\text { in Hershler } \\
\text { and Liu } \\
(2010), \\
\text { placed under } \\
\text { clade F in } \\
\text { Hershler et } \\
\text { al. (2013), } \\
\text { described as } \\
\text { P. ojaiensis in } \\
\text { Hershler et al. } \\
\text { (2016b) }\end{array}$ \\
\hline $\begin{array}{l}\text { Pyrgulopsis } \\
\text { owensensis }\end{array}$ & P34 & $\begin{array}{c}\text { AF520922 } \\
(P 34 C, N=1) \\
\text { GQ275089 } \\
(P 34 A A, N=2) \\
\text { GQ275090 } \\
(P 34 A B, N=2)\end{array}$ & 5 & $0-0.5 \%$ & & $\begin{array}{l}\text { P. perturbata, } \\
\text { differ by } \\
1.0-1.3 \%\end{array}$ & $\begin{array}{l}\text { Spring, Graham } \\
\text { Ranch, ca. } 8.0 \mathrm{~km} \\
\text { E of Big Pine, Inyo } \\
\text { Co., CA }\end{array}$ & \\
\hline \multirow[t]{4}{*}{$\begin{array}{l}\text { Pyrgulopsis } \\
\text { owyheensis }\end{array}$} & IF59 & $\begin{array}{c}\text { FJ172457 } \\
(\text { IP59A, N=1), } \\
\text { FJ172458 } \\
\text { (IP59C, N=1), } \\
\text { FJ172459 } \\
(\text { IP59D, N=1) }\end{array}$ & 3 & $0.2-0.3 \%$ & $\begin{array}{c}1.8-2.1 \% \\
\text { with P211, } \\
1.8-2.0 \% \\
\text { with } \mathrm{P} 213\end{array}$ & $\begin{array}{c}\text { P. aurata, } \\
\text { differ by } \\
4.7-4.9 \% \text {, } \\
\text { P. kolobensis, } \\
\text { differ by } \\
4.2-5.9 \% \text {, } \\
\text { P. pictilis, differ } \\
\text { by } 4.7-4.8 \% \text {, } \\
\text { P. plicata, differ } \\
\text { by } 4.7-4.8 \% \text {, } \\
\text { P. sublata, differ } \\
\text { by } 4.6-4.8 \%\end{array}$ & $\begin{array}{l}\text { Owyhee Spring, } \\
\text { Malheur Co., OR }\end{array}$ & $\begin{array}{l}\text { Pyrgulopsis } \\
\text { sp. } 3 \\
\text { HPL2008 } \\
\text { isolate } \\
\text { IP59A, } \\
\text { IP59C, } \\
\text { IP59D in } \\
\text { GenBank }\end{array}$ \\
\hline & IP62 & $\begin{array}{c}\text { FJ172464 } \\
(\text { IP62A, N=1), } \\
\text { FJ172465 } \\
(\text { IP62B, N=1), } \\
\text { FJ172466 } \\
(\text { IP62C, N=1), } \\
\text { FJ172467 } \\
(\text { IP62D, N=1) }\end{array}$ & 4 & $0.00 \%$ & $\begin{array}{l}1.5-1.7 \% \\
\text { with IP59 }\end{array}$ & $\begin{array}{l}\text { P. kolobensis, } \\
\text { differ by } \\
4.0-5.7 \% \text {, } \\
\text { P. plicata, } \\
\text { differ by } 4.7 \%\end{array}$ & $\begin{array}{l}\text { Tree Spring, } \\
\text { Malheur Co., OR }\end{array}$ & $\begin{array}{l}\text { Pyrgulopsis } \\
\text { sp. } 3 \\
\text { HPL2008 } \\
\text { isolate } \\
\text { IP62A, IP62B, } \\
\text { IP62C, IP62D } \\
\text { in GenBank }\end{array}$ \\
\hline & P177B & FJ172475 & 1 & $0.00 \%$ & $\begin{array}{l}2.0-2.1 \% \\
\text { with IP59 }\end{array}$ & $\begin{array}{c}\text { P. bryanwalkeri, } \\
\text { differ by } 5.0 \% \text {, } \\
\text { P. kolobensis, } \\
\text { differ by } \\
4.2-5.7 \% \text {, } \\
\text { P. plicata, } \\
\text { differ by } 5.0 \% \text {, }\end{array}$ & $\begin{array}{l}\text { Tudor Warm } \\
\text { Springs, east side } \\
\text { of river, second } \\
\text { spring from north, } \\
\text { Malheur Co., OR }\end{array}$ & $\begin{array}{l}\text { Pyrgulopsis } \\
\text { sp. } 3 \\
\text { HPL2008 } \\
\text { isolate } \\
\text { P177B in } \\
\text { GenBank }\end{array}$ \\
\hline & P209 & FJ172479 & 5 & $0.00 \%$ & $\begin{array}{c}1.4-1.5 \% \text { with } \\
\text { IP59 }\end{array}$ & $\begin{array}{c}\text { P. lentiglans, } \\
\text { differ by } 4.8 \% \text {, } \\
\text { P. kolobensis, } \\
\text { differ by } \\
4.2-5.7 \% \\
\text { P. pictilis, } \\
\text { differ by } 4.8 \% \text {, } \\
\text { P. plicata, } \\
\text { differ by } 4.8 \%\end{array}$ & $\begin{array}{l}\text { Kane Springs, } \\
\text { Malheur River } \\
\text { basin, Malheur } \\
\text { Co., OR }\end{array}$ & $\begin{array}{l}\text { Pyrgulopsis } \\
\text { sp. } 3 \\
\text { HPL2008 } \\
\text { isolate } \\
\text { P209A in } \\
\text { GenBank }\end{array}$ \\
\hline
\end{tabular}




\begin{tabular}{|c|c|c|c|c|c|c|c|c|}
\hline Species & $\begin{array}{l}\text { Published } \\
\text { Sample } \\
\text { Codes }\end{array}$ & $\begin{array}{l}\text { Accession } \\
\text { Numbers }\end{array}$ & $\begin{array}{c}\text { No. of } \\
\text { Specimens }(\mathrm{N})\end{array}$ & $\begin{array}{l}\text { Sequence } \\
\text { Variation } \\
\text { (\% pairwise } \\
\text { distance) }\end{array}$ & $\begin{array}{l}\text { Most Distant } \\
\text { Conspecific } \\
\text { Sequences (\%) }\end{array}$ & $\begin{array}{c}\text { Closest } \\
\text { Interspecific } \\
\text { Sequences (\%) }\end{array}$ & Collection Locality & Comments \\
\hline \multirow[t]{8}{*}{$\begin{array}{l}\text { Pyrgulopsis } \\
\text { owyheensis } \\
\text { (continued) }\end{array}$} & P211 & $\begin{array}{c}F J 172481 \\
(P 211 A, N=1), \\
F J 172482 \\
(P 211 B, N=1)\end{array}$ & 2 & $0.20 \%$ & $\begin{array}{c}1.8-2.1 \% \\
\text { with IP59 }\end{array}$ & $\begin{array}{l}\text { P. kolobensis, } \\
\text { differ by } \\
4.4-6.4 \% \\
\text { P. plicata, } \\
\text { differ by } \\
4.7-4.8 \%\end{array}$ & $\begin{array}{l}\text { Tudor Warm } \\
\text { Springs, east side } \\
\text { of river, third spring } \\
\text { from north, Malheur } \\
\text { Co., OR }\end{array}$ & $\begin{array}{l}\text { Pyrgulopsis } \\
\text { sp. } 3 \\
\text { HPL2008 } \\
\text { isolate } \\
\text { P21AA, } \\
\text { P211B in } \\
\text { GenBank }\end{array}$ \\
\hline & P213A & FJ172484 & 1 & $0.00 \%$ & $\begin{array}{l}1.8-2.0 \% \\
\text { with IP59 }\end{array}$ & $\begin{array}{l}\text { P. kolobensis, } \\
\text { differ by } \\
4.4-5.9 \% \text {, } \\
\text { P. plicata, } \\
\text { differ by } 4.7 \%\end{array}$ & $\begin{array}{l}\text { Tudor Warm } \\
\text { Springs, east side } \\
\text { of river, second } \\
\text { spring from north, } \\
\text { Malheur Co., OR }\end{array}$ & $\begin{array}{l}\text { Pyrgulopsis } \\
\text { sp. } 3 \\
\text { HPL2008 } \\
\text { isolate P213A } \\
\text { in GenBank }\end{array}$ \\
\hline & P215 & FJ172485 & 2 & $0.00 \%$ & $\begin{array}{c}1.5-1.7 \% \\
\text { with IP59 }\end{array}$ & $\begin{array}{c}\text { P. kolobensis, } \\
\text { differ by } \\
4.4-5.7 \%, \\
\text { P. lentiglans, } \\
\text { differ by } 4.8 \%\end{array}$ & $\begin{array}{l}\text { Spring tributary } \\
\text { to Owyhee River } \\
\text { upflow from Tudor } \\
\text { Warm Springs, } \\
\text { Malheur Co., OR }\end{array}$ & $\begin{array}{l}\text { Pyrgulopsis } \\
\text { sp. } 3 \\
\text { HPL2008 } \\
\text { isolate P215A } \\
\text { in GenBank }\end{array}$ \\
\hline & P216 & $\begin{array}{l}\text { FJ172486 } \\
(P 216 A) \\
\text { FJ172487 } \\
(P 216 B)\end{array}$ & 4 & $0.30 \%$ & $\begin{array}{r}1.4-1.5 \% \\
\text { with IP59 }\end{array}$ & $\begin{array}{l}\text { P. kolobensis, } \\
\text { differ by } \\
3.9-5.5 \% \\
\text { P. lentiglans, } \\
\text { differ by } \\
4.8-4.9 \%\end{array}$ & $\begin{array}{l}\text { Spring on Owyhee } \\
\text { River, below mouth } \\
\text { of Crooked Creek, } \\
\text { Malheur Co., OR }\end{array}$ & $\begin{array}{l}\text { Pyrgulopsis } \\
\text { sp. } 3 \\
\text { HPL2008 } \\
\text { isolate } \\
\text { P216A, P216B } \\
\text { in GenBank }\end{array}$ \\
\hline & P218 & $\begin{array}{l}\text { FJ172489 } \\
\text { (P218A), } \\
\text { FJ172490 } \\
\text { (P218B), } \\
\text { FJ172491 } \\
\text { (P218C) }\end{array}$ & 4 & $0-0.5 \%$ & $\begin{array}{r}1.4-1.7 \% \\
\text { with IP59 }\end{array}$ & $\begin{array}{l}\text { P. kolobensis, } \\
\text { differ by } \\
3.9-5.5 \% \\
\text { P. plicata, differ } \\
\text { by } 4.5-4.7 \% \text {, } \\
\text { P. sublata, differ } \\
\text { by } 4.5-4.8 \%\end{array}$ & $\begin{array}{l}\text { Spring on Owyhee } \\
\text { River, above Long } \\
\text { Sweetwater rapids, } \\
\text { Malheur Co., OR }\end{array}$ & $\begin{array}{l}\text { Pyrgulopsis } \\
\text { sp. } 3 \\
\text { HPL2008 } \\
\text { isolate } \\
\text { P218A, } \\
\text { P218B, P218C } \\
\text { in GenBank }\end{array}$ \\
\hline & $\begin{array}{l}\text { P219, } \\
\text { P220 }\end{array}$ & $\begin{array}{l}\text { FJ172492 } \\
\text { (P219A), } \\
\text { FJ172493 } \\
\text { (P220B), } \\
\text { FJ172494 } \\
\text { (P220C) }\end{array}$ & 7 & $0.0 .3 \%$ & $\begin{array}{r}1.4-1.5 \% \\
\text { with IP59 }\end{array}$ & $\begin{array}{l}\text { P. kolobensis, } \\
\text { differ by } \\
3.9-5.7 \% \\
\text { P. plicata, differ } \\
\text { by } 4.5-4.8 \%\end{array}$ & $\begin{array}{l}\text { Weeping Wall } \\
\text { springs, just below } \\
\text { mouth of Granite } \\
\text { Creek, Malheur } \\
\text { Co., OR }\end{array}$ & $\begin{array}{l}\text { Pyrgulopsis } \\
\text { sp. } 3 \\
\text { HPL2008 } \\
\text { isolate } \\
\text { P219A, } \\
\text { P220B, P220C } \\
\text { in GenBank }\end{array}$ \\
\hline & P221 & FJ172495 & 3 & $0.00 \%$ & $\begin{array}{r}1.4-1.5 \% \\
\text { with IP59 }\end{array}$ & $\begin{array}{l}\text { P. kolobensis, } \\
\text { differ by } \\
3.9-5.5 \%, \\
\text { P. plicata, } \\
\text { differ by } 4.5 \%\end{array}$ & $\begin{array}{l}\text { Spring on Owyhee } \\
\text { River, above } \\
\text { Artillery rapids, } \\
\text { Malheur Co., OR }\end{array}$ & $\begin{array}{l}\text { Pyrgulopsis } \\
\text { sp. } 3 \\
\text { HPL2008 } \\
\text { isolate P221B } \\
\text { in GenBank }\end{array}$ \\
\hline & $\begin{array}{l}\text { P225, } \\
\text { P226 }\end{array}$ & $\begin{array}{l}\text { FJ172501 } \\
(P 225 A), \\
\text { FJ172502 } \\
(P 226 A)\end{array}$ & 4 & $0.30 \%$ & $\begin{array}{r}1.4-1.5 \% \\
\text { with IP59 }\end{array}$ & $\begin{array}{l}\text { P. kolobensis, } \\
\text { differ by } \\
3.9-5.5 \% \text {, } \\
\text { P. plicata, differ } \\
\text { by } 4.5-4.7 \% \text {, } \\
\text { P. sublata, differ } \\
\text { by } 4.6-4.8 \%\end{array}$ & $\begin{array}{l}\text { Seep wall on } \\
\text { Owyhee River, just } \\
\text { above mouth of } \\
\text { Crooked Creek, } \\
\text { Malheur Co., OR }\end{array}$ & $\begin{array}{l}\text { Pyrgulopsis } \\
\text { sp. } 3 \\
\text { HPL2008 } \\
\text { isolate } \\
\text { P225A, } \\
\text { P226A in } \\
\text { GenBank }\end{array}$ \\
\hline $\begin{array}{l}\text { Pyrgulopsis } \\
\text { peculiaris }\end{array}$ & & AF520912 & 1 & $0.00 \%$ & & $\begin{array}{l}\text { P. kolobensis, } \\
\text { differ by } \\
5.9-6.9 \% \text {, } \\
\text { P. pilsbryana, } \\
\text { differ by } \\
5.9-6.1 \% \text {, } \\
\text { P. sp. D, differ } \\
\text { by } 5.9 \%\end{array}$ & $\begin{array}{l}\text { Spring above } \\
\text { Swasey Spring, } \\
\text { Whirlwind Valley, } \\
\text { Millard Co., UT }\end{array}$ & \\
\hline $\begin{array}{l}\text { Pyrgulopsis } \\
\text { pellita }\end{array}$ & P125A & AY 627943 & 1 & $0.00 \%$ & & $\begin{array}{l}\text { P. bifurcata, } \\
\text { differ by } 3.3 \%\end{array}$ & $\begin{array}{l}\text { Sullivan Spring, } \\
\text { Antelope Valley, } \\
\text { Eureka Co., NV }\end{array}$ & \\
\hline
\end{tabular}




\begin{tabular}{|c|c|c|c|c|c|c|c|c|}
\hline Species & $\begin{array}{l}\text { Published } \\
\text { Sample } \\
\text { Codes }\end{array}$ & $\begin{array}{l}\text { Accession } \\
\text { Numbers }\end{array}$ & $\begin{array}{c}\text { No. of } \\
\text { Specimens }(N)\end{array}$ & $\begin{array}{l}\text { Sequence } \\
\text { Variation } \\
\text { (\% pairwise } \\
\text { distance) }\end{array}$ & $\begin{array}{l}\text { Most Distant } \\
\text { Conspecific } \\
\text { Sequences (\%) }\end{array}$ & $\begin{array}{c}\text { Closest } \\
\text { Interspecific } \\
\text { Sequences (\%) }\end{array}$ & Collection Locality & Comments \\
\hline \multirow[t]{3}{*}{$\begin{array}{l}\text { Pyrgulopsis } \\
\text { perforata }\end{array}$} & M3 & $\begin{array}{c}\text { AY367433 } \\
(\text { M3A) } \\
\text { AY367434 } \\
(\text { M } 3 B, M 30)\end{array}$ & 3 & $0.00 \%$ & $\begin{array}{l}0.2-0.3 \% \\
\text { with } \mathrm{M} 4\end{array}$ & $\begin{array}{l}\text { P. conica, differ } \\
\text { by } 2.6 \% \text {, } \\
\text { P. diablensis, } \\
\text { differ by } 2.6 \% \text {, } \\
\text { P. glandulosa, } \\
\text { differ by } \\
2.6-2.7 \% \text {, } \\
\text { P. simplex, differ } \\
\text { by } 2.7 \%\end{array}$ & $\begin{array}{l}\text { Spring east of } \\
\text { Scottys Castle, } \\
\text { Grapevine Canyon, } \\
\text { Death Valley, Inyo } \\
\text { Co., CA }\end{array}$ & $\begin{array}{l}\text { P. micrococcus } \\
\text { in GenBank }\end{array}$ \\
\hline & M4 & $\begin{array}{l}\text { AY367435 } \\
(\mathrm{M} 4 \mathrm{~A}) \\
\text { AY367436 } \\
(\mathrm{M} 4 \mathrm{~B})\end{array}$ & 2 & $0.50 \%$ & $\begin{array}{c}0.2-0.3 \% \\
\text { with } \mathrm{M} 3 \text {, } \\
0-0.5 \% \\
\text { with M5 }\end{array}$ & $\begin{array}{l}\text { P. conica, differ } \\
\text { by } 2.6-2.7 \% \text {, } \\
\text { P. diablensis, } \\
\text { differ by } \\
2.6-2.7 \% \text {, } \\
\text { P. glandulosa, } \\
\text { differ by } \\
2.4-2.7 \% \text {, } \\
\text { P. simplex, differ } \\
\text { by } 2.6-2.7 \%\end{array}$ & $\begin{array}{l}\text { Spring west of } \\
\text { Scottys Castle, } \\
\text { Grapevine Canyon, } \\
\text { Death Valley, Inyo } \\
\text { Co., CA }\end{array}$ & $\begin{array}{l}\text { P. micrococcus } \\
\text { in GenBank }\end{array}$ \\
\hline & M5 & $\begin{array}{c}\text { AY } 367437 \\
\text { (M5A) }\end{array}$ & 1 & $0.00 \%$ & $\begin{array}{c}0.2 \% \\
\text { with } \mathrm{M} 3 \text {, } \\
0-0.5 \% \\
\text { with } \mathrm{M} 4\end{array}$ & \begin{tabular}{|} 
P. conica, differ \\
by $2.6 \%$, \\
P. diablensis, \\
differ by $2.7 \%$, \\
P. glandulosa, \\
differ by \\
$2.4-2.6 \%$, \\
P. simplex, differ \\
by $2.6 \%$ \\
\end{tabular} & $\begin{array}{l}\text { Surprise Spring, } \\
\text { Death Valley, Inyo } \\
\text { Co., CA } \\
\end{array}$ & $\begin{array}{l}\text { P. micrococcus } \\
\text { in GenBank }\end{array}$ \\
\hline $\begin{array}{l}\text { Pyrgulopsis } \\
\text { perturbata }\end{array}$ & & AY367488 & 1 & $0.00 \%$ & & $\begin{array}{l}\text { P. owensensis, } \\
\text { differ by } \\
1.0-1.3 \%\end{array}$ & $\begin{array}{l}\text { Northeast Spring, } \\
\text { Fish Slough, Owens } \\
\text { River basin, Mono } \\
\text { Co., CA }\end{array}$ & \\
\hline $\begin{array}{l}\text { Pyrgulopsis } \\
\text { pictilis }\end{array}$ & P126A & AY 627944 & 1 & $0.00 \%$ & & $\begin{array}{c}\text { P. aurata, differ } \\
\text { by } 0.0 \% \text {, } \\
\text { P. bryantwalkeri, } \\
\text { differ by } 0.3 \% \text {, } \\
\text { P. kolobensis, } \\
\text { differ by } \\
1.7-2.9 \% \text {, } \\
\text { P. sp. B, differ } \\
\text { by } 1.9 \% \\
\end{array}$ & $\begin{array}{l}\text { Cain Spring, } \\
\text { Antelope Valley, } \\
\text { Lander Co., NV }\end{array}$ & \\
\hline \multirow[t]{2}{*}{$\begin{array}{l}\text { Pyrgulopsis } \\
\text { pilsbryana }\end{array}$} & P137 & AY426363-64 & 2 & $0.00 \%$ & $\begin{array}{l}0.2 \% \\
\text { with } \\
\text { P159A }\end{array}$ & $\begin{array}{c}\text { P. kolobensis, } \\
\text { differ by } \\
0.2-2.9 \% \text {, } \\
\text { P. transversa, } \\
\text { differ by } 1.0 \% \text {, } \\
\text { P. sp. C, differ } \\
\text { by } 0.2 \% \text {, } \\
\text { P. sp. D, differ } \\
\text { by } 0.0 \% \text {, } \\
\text { P. sp. H, differ } \\
\text { by } 0.2 \%\end{array}$ & $\begin{array}{l}\text { Spring, Saint } \\
\text { Charles Creek, Bear } \\
\text { Lake Valley, Bear } \\
\text { Lake Co., ID }\end{array}$ & \\
\hline & P159A & EU700475 & 1 & $0.00 \%$ & $\begin{array}{l}0.2 \% \\
\text { with } \\
\text { P137 }\end{array}$ & $\begin{array}{c}\text { P. kolobensis, } \\
\text { differ by } \\
0.2-2.7 \% \text {, } \\
\text { P. transversa, } \\
\text { differ by } 1.1 \% \text {, } \\
\text { P. sp. C, } \\
\text { differ by } 0.0 \% \text {, } \\
\text { P. sp. } D \\
\text { differ by } 0.2 \% \text {, } \\
\text { P. sp. H. differ } \\
\text { by } 0.0 \%\end{array}$ & $\begin{array}{l}\text { Bear River, Black } \\
\text { Canyon, Caribou } \\
\text { Co., ID }\end{array}$ & $\begin{array}{l}\text { Pyrgulopsis } \\
\text { sp. Black } \\
\text { Canyon } \\
\text { isolate } \\
\text { P159A in } \\
\text { GenBank }\end{array}$ \\
\hline
\end{tabular}




\begin{tabular}{|c|c|c|c|c|c|c|c|c|}
\hline Species & $\begin{array}{l}\text { Published } \\
\text { Sample } \\
\text { Codes }\end{array}$ & $\begin{array}{l}\text { Accession } \\
\text { Numbers }\end{array}$ & $\begin{array}{c}\text { No. of } \\
\text { Specimens }(\mathrm{N})\end{array}$ & $\begin{array}{l}\text { Sequence } \\
\text { Variation } \\
\text { (\% pairwise } \\
\text { distance) }\end{array}$ & $\begin{array}{l}\text { Most Distant } \\
\text { Conspecific } \\
\text { Sequences (\%) }\end{array}$ & $\begin{array}{c}\text { Closest } \\
\text { Interspecific } \\
\text { Sequences (\%) }\end{array}$ & Collection Locality & Comments \\
\hline $\begin{array}{l}\text { Pyrgulopsis } \\
\text { pisteri }\end{array}$ & P157A & DQ364004 & 1 & $0.00 \%$ & & $\begin{array}{c}\text { P. crystalis, } \\
\text { differ by } 0.6 \% \text {, } \\
\text { P. erythropoma, } \\
\text { differ by } 4.5 \%\end{array}$ & $\begin{array}{l}\text { Marsh Spring, } \\
\text { Ash Meadows, } \\
\text { Amargosa River } \\
\text { basin, Nye Co., NV }\end{array}$ & \\
\hline $\begin{array}{c}\text { Pyrgulopsis } \\
\text { plicata }\end{array}$ & P99A & AY627935 & 1 & $0.00 \%$ & & $\begin{array}{c}\text { P. marcida, } \\
\text { differ by } 1.6 \%\end{array}$ & $\begin{array}{l}\text { Spring, Black } \\
\text { Canyon, Sevier } \\
\text { River drainage, } \\
\text { Garfield Co., UT }\end{array}$ & \\
\hline \multirow[t]{11}{*}{$\begin{array}{l}\text { Pyrgulopsis } \\
\text { robusta }\end{array}$} & $\begin{array}{c}\mathrm{HL/} \\
\text { hendersonil/ } \\
\text { P3 }\end{array}$ & $\begin{array}{l}\text { AY197594/ } \\
\text { AY379430-31 }\end{array}$ & 2 & $0.00 \%$ & $\begin{array}{c}0.5 \% \text { with P171, } \\
\text { Ida, P181, 0.5- } \\
0.6 \% \text { with P179 }\end{array}$ & $\begin{array}{l}\text { P. intermedia, } \\
\text { differ by } \\
2.6-3.1 \%\end{array}$ & $\begin{array}{l}\text { Hughet Spring, } \\
\text { Harney-Malheur } \\
\text { Lakes, Harney Co., } \\
\text { OR }\end{array}$ & $\begin{array}{l}\text { P. hendersoni/ } \\
\text { robusta in } \\
\text { GenBank }\end{array}$ \\
\hline & $\begin{array}{c}\text { MA/ } \\
\text { hendersoni2/ } \\
\text { P5 }\end{array}$ & $\begin{array}{l}\text { AY197595/ } \\
\text { AY379432-33 }\end{array}$ & 2 & $0.00 \%$ & $\begin{array}{c}0.5 \% \text { with } P 171, \\
\text { Ida, P181, } 0.5- \\
0.6 \% \text { with P179 }\end{array}$ & $\begin{array}{l}\text { P. intermedia, } \\
\text { differ by } \\
2.6-3.1 \%\end{array}$ & $\begin{array}{l}\text { Spring at South } \\
\text { Fork (Malheur } \\
\text { River) Reservoir, } \\
\text { middle Snake River } \\
\text { basin, Malheur } \\
\text { Co., OR }\end{array}$ & $\begin{array}{l}\text { P. hendersonil } \\
\text { robusta in } \\
\text { GenBank }\end{array}$ \\
\hline & $\begin{array}{c}\text { D33/ } \\
\text { herdersoni3 }\end{array}$ & $\begin{array}{l}\text { AY379434-35, } \\
\text { AY426348-49 }\end{array}$ & 4 & $0.2-0.3 \%$ & $\begin{array}{c}0.5-0.8 \% \text { with } \\
\text { P179 }\end{array}$ & $\begin{array}{l}\text { P. intermedia, } \\
\text { differ by } \\
2.6-3.2 \%\end{array}$ & $\begin{array}{l}\text { XL Spring, Abert } \\
\text { Lake basin (Great } \\
\text { Basin), Lake Co., } \\
\text { OR }\end{array}$ & $\begin{array}{l}\text { P. hendersoni/ } \\
\text { robusta in } \\
\text { GenBank }\end{array}$ \\
\hline & $\begin{array}{c}\mathrm{P} 171 / \\
\text { idahoensis1 }\end{array}$ & AY379424-25 & 2 & $0.00 \%$ & $\begin{array}{c}0.5-0.6 \% \text { with } \\
\text { D33 }\end{array}$ & $\begin{array}{l}\text { P. intermedia, } \\
\text { differ by } \\
2.6-3.0 \%\end{array}$ & $\begin{array}{l}\text { Bruneau Arm of } \\
\text { CJ Strike Reservoir, } \\
\text { (Bruneau) river mile } \\
\text { 3.8, Owyhee Co., ID }\end{array}$ & \\
\hline & $\begin{array}{c}\text { P179/ } \\
\text { idahoensis2 }\end{array}$ & AY379426-27 & 2 & $0.20 \%$ & $\begin{array}{l}0.3-0.8 \% \text { with } \\
\text { D30, 0.5-0.8\% } \\
\text { with D33 }\end{array}$ & $\begin{array}{l}\text { P. intermedia, } \\
\text { differ by } \\
2.6-3.2 \%\end{array}$ & $\begin{array}{l}\text { Snake River river } \\
\text { mile } 538.1 \text {, Glenns } \\
\text { Ferry, Snake River } \\
\text { basin, Elmore } \\
\text { Co., ID }\end{array}$ & \\
\hline & Ida & AY426346-47 & 2 & $0.00 \%$ & $\begin{array}{l}0.3-0.6 \% \text { with } \\
\text { D30, } 0.5-0.6 \% \\
\text { with D33 }\end{array}$ & $\begin{array}{l}\text { P. intermedia, } \\
\text { differ by } \\
2.6-3.0 \%\end{array}$ & $\begin{array}{l}\text { Snake River, river } \\
\text { mile } 446.8 \text {, Canyon } \\
\text { Co., ID }\end{array}$ & $\begin{array}{l}\text { P. idahoensis } \\
\text { in GenBank }\end{array}$ \\
\hline & $\begin{array}{c}\mathrm{P} 181 / \\
\text { Idahoensis3 }\end{array}$ & AY379428-29 & 2 & $0.00 \%$ & $\begin{array}{l}0.3-0.6 \% \text { with } \\
\text { D30, } 0.5-0.6 \% \\
\text { with D33 }\end{array}$ & $\begin{array}{l}\text { P. intermedia, } \\
\text { differ by } \\
2.6-3.0 \%\end{array}$ & $\begin{array}{l}\text { Snake River, river } \\
\text { mile } 365.9,366.3 \text {, } \\
367.2 \text {, Malheur } \\
\text { Co., OR }\end{array}$ & \\
\hline & $\begin{array}{l}\text { P178/ } \\
\text { robusta }\end{array}$ & AY379436-37 & 2 & $0.00 \%$ & $\begin{array}{c}0.3-0.5 \% \text { with } \\
\text { P179 }\end{array}$ & $\begin{array}{l}\text { P. intermedia, } \\
\text { differ by } \\
2.7-3.2 \%\end{array}$ & $\begin{array}{l}\text { Spring, tributary to } \\
\text { Polecat Creek, } \\
\text { Teton Co., WY }\end{array}$ & \\
\hline & P47B & AF520949 & 1 & $0.00 \%$ & $\begin{array}{c}0.5-0.7 \% \text { with } \\
\text { P179 }\end{array}$ & $\begin{array}{l}\text { P. intermedia, } \\
\text { differ by } \\
3.0-3.5 \%\end{array}$ & $\begin{array}{l}\text { Polecat Creek, west } \\
\text { of Flagg Ranch, } \\
\text { Teton Co., WY }\end{array}$ & \\
\hline & D30/spA1 & AY379438-39 & 2 & $0.30 \%$ & $\begin{array}{c}0.3-0.8 \% \text { with } \\
\text { P179 }\end{array}$ & $\begin{array}{l}\text { P. intermedia, } \\
\text { differ by } \\
2.7-3.2 \%\end{array}$ & $\begin{array}{l}\text { Columbia River, } \\
\text { East Mayer State } \\
\text { Park, Wasco } \\
\text { Co., OR }\end{array}$ & \\
\hline & $\mathrm{P} 49 / \mathrm{spA} 2$ & AY379440-41 & 2 & $0.00 \%$ & $\begin{array}{c}0.5 \% \text { with } P 171 \text {, } \\
\text { Ida, P181, 0.5- } \\
0.6 \% \text { with P179 }\end{array}$ & $\begin{array}{l}\text { P. intermedia, } \\
\text { differ by } \\
2.8-3.4 \%\end{array}$ & $\begin{array}{l}\text { Columbia River, } \\
\text { Celilo State Park, } \\
\text { Wasco Co., OR }\end{array}$ & \\
\hline $\begin{array}{l}\text { Pyrgulopsis } \\
\text { rupinicola }\end{array}$ & $\begin{array}{l}\text { SS1/D3, } \\
\text { SS2/D3 }\end{array}$ & $\begin{array}{l}\text { AY } 197590 \\
(N=3), \\
\text { AY } 197591 \\
(N=1)\end{array}$ & 4 & $0-0.5 \%$ & & $\begin{array}{l}\text { P. archimedis, } \\
\text { differ by } \\
2.6-3.2 \% \text {, } \\
\text { P. sp. A, differ } \\
\text { by } 2.4-3.4 \%\end{array}$ & $\begin{array}{l}\text { Sucker Springs } \\
\text { Creek, Shasta Co., } \\
\text { CA }\end{array}$ & \\
\hline
\end{tabular}




\begin{tabular}{|c|c|c|c|c|c|c|c|c|}
\hline Species & $\begin{array}{l}\text { Published } \\
\text { Sample } \\
\text { Codes }\end{array}$ & $\begin{array}{l}\text { Accession } \\
\text { Numbers }\end{array}$ & $\begin{array}{c}\text { No. of } \\
\text { Specimens (N) }\end{array}$ & $\begin{array}{l}\text { Sequence } \\
\text { Variation } \\
(\% \text { pairwise } \\
\text { distance }) \\
\end{array}$ & $\begin{array}{l}\text { Most Distant } \\
\text { Conspecific } \\
\text { Sequences (\%) }\end{array}$ & $\begin{array}{c}\text { Closest } \\
\text { Interspecific } \\
\text { Sequences (\%) }\end{array}$ & Collection Locality & Comments \\
\hline $\begin{array}{c}\text { Pyrgulopsis } \\
\text { sadai }\end{array}$ & P141A & AY 627945 & 1 & $0.00 \%$ & & $\begin{array}{l}\text { P. kolobensis, } \\
\text { differ by } \\
6.2-7.8 \% \\
\text { P. pilsbryana, } \\
\text { differ by } \\
6.2-6.5 \% \\
\text { P. sp. C, differ } \\
\text { by } 6.2-6.3 \%\end{array}$ & $\begin{array}{l}\text { Spring, Moss Creek, } \\
\text { Reese River Valley, } \\
\text { Lander Co., NV }\end{array}$ & \\
\hline \multirow[t]{8}{*}{$\begin{array}{l}\text { Pyrgulopsis } \\
\text { sanchezi }\end{array}$} & $M 2$ & $\begin{array}{c}A Y 367430-32 \\
(M 2 A-O)\end{array}$ & 15 & $0.00 \%$ & $\begin{array}{c}2.0-2.1 \% \\
\text { with } \mathrm{M} 25 \text {, } \\
1.7-2.1 \% \\
\text { with } \mathrm{M} 26 \text {, } \\
1.8-2.1 \% \\
\text { with SS } \\
\end{array}$ & $\begin{array}{c}\text { P. coloradensis, } \\
\text { differ by } 4.1 \%\end{array}$ & $\begin{array}{l}\text { Grapevine Springs, } \\
\text { Death Valley, Inyo } \\
\text { Co., CA }\end{array}$ & $\begin{array}{l}\text { P. micrococcus } \\
\text { in GenBank }\end{array}$ \\
\hline & M8 & $\begin{array}{c}\text { AY367440 } \\
\text { (M8A) } \\
\text { DQ364001 } \\
(N=9, P 197 A \\
\text { M8AA-AH) }\end{array}$ & 10 & $0-0.2 \%$ & $\begin{array}{l}2.1-2.4 \% \\
\text { with SS }\end{array}$ & $\begin{array}{c}\text { P. arizonae, } \\
\text { differ by } \\
4.1-5.6 \% \\
\text { P. coloradensis, } \\
\text { differ by } \\
4.3-4.4 \%\end{array}$ & $\begin{array}{l}\text { Purgatory Spring, } \\
\text { Ash Meadows, Nye } \\
\text { Co., NV }\end{array}$ & $\begin{array}{l}\text { P. micrococcus } \\
\text { in GenBank }\end{array}$ \\
\hline & M25 & $\begin{array}{c}\text { AY367469 } \\
(\text { M25A), } \\
\text { AY367470-71 } \\
(N=8, M 25 B-C, \\
\text { AB-AD, AG-AI) }\end{array}$ & 9 & $0.20 \%$ & $\begin{array}{l}2.0-2.1 \% \\
\text { with } \mathrm{M} 2\end{array}$ & $\begin{array}{l}\text { P. coloradensis, } \\
\text { differ by } \\
4.1-4.3 \%\end{array}$ & $\begin{array}{l}\text { Spring north of } \\
\text { Tecopa Hot } \\
\text { Springs, Amargosa } \\
\text { River basin, Inyo } \\
\text { Co., CA }\end{array}$ & $\begin{array}{l}\text { P. micrococcus } \\
\text { in GenBank }\end{array}$ \\
\hline & M26 & $\begin{array}{c}\text { AY367472 } \\
(\mathrm{N}=5, \mathrm{M} 26 \mathrm{~A}, \\
\mathrm{AD}-\mathrm{AE}, \mathrm{AG}, \mathrm{Al}), \\
\mathrm{AY} 367473 \\
(\mathrm{~N}=3, \mathrm{M} 26 \mathrm{~B}, \\
\mathrm{M} 26 \mathrm{C} \\
\mathrm{M} 26 \mathrm{AC}) \\
\mathrm{KF559187} \\
(\mathrm{N}=5, \mathrm{M} 26 \mathrm{AA}- \\
\mathrm{AB}, \mathrm{AF}, \mathrm{AH}, \mathrm{AJ}) \\
\text { KF559188 } \\
\text { (M26AK) }\end{array}$ & 14 & $0-0.5 \%$ & $\begin{array}{l}1.8-2.2 \% \\
\text { with SS, } \\
1.7-2.1 \% \\
\text { with } \mathrm{M} 2\end{array}$ & $\begin{array}{c}\text { P. arizonae, } \\
\text { differ by } \\
4.7-6.2 \% \text {, } \\
\text { P. coloradensis, } \\
\text { differ by } \\
4.6-5.0 \%\end{array}$ & $\begin{array}{l}\text { Shoshone Spring, } \\
\text { Amargosa River } \\
\text { basin, Inyo Co., CA }\end{array}$ & $\begin{array}{l}\text { P. micrococcus } \\
\text { in GenBank }\end{array}$ \\
\hline & M51 & $\begin{array}{l}\text { KF559184 } \\
\text { (M51A-B) }\end{array}$ & 2 & $0.00 \%$ & $\begin{array}{l}2.1-2.2 \% \\
\text { with SS }\end{array}$ & $\begin{array}{c}\text { P. coloradensis, } \\
\text { differ by } 3.8 \%\end{array}$ & $\begin{array}{l}\text { Spring ca. } 100 \mathrm{~m} \\
\text { north of Collins } \\
\text { Ranch, Ash } \\
\text { Meadows, Nye Co., } \\
\text { NV }\end{array}$ & \\
\hline & M53 & $\begin{array}{l}\text { KF559185 } \\
\text { (M53A-C) }\end{array}$ & 3 & $0.00 \%$ & $\begin{array}{l}2.1-2.2 \% \\
\text { with SS }\end{array}$ & $\begin{array}{c}\text { P. coloradensis, } \\
\text { differ by } 4.1 \%\end{array}$ & $\begin{array}{l}\text { Spring south of } \\
\text { Rogers Spring, } \\
\text { Ash Meadows, Nye } \\
\text { Co., NV }\end{array}$ & \\
\hline & M57 & $\begin{array}{l}\text { KF559186 } \\
\text { (M57A-B) }\end{array}$ & 2 & $0.00 \%$ & $\begin{array}{l}2.1-2.2 \% \\
\text { with SS }\end{array}$ & $\begin{array}{l}\text { P. coloradensis, } \\
\text { differ by } 3.8 \%\end{array}$ & $\begin{array}{l}\text { Spring east of } \\
\text { Crystal Reservoir, } \\
\text { Ash Meadows, Nye } \\
\text { Co., NV }\end{array}$ & \\
\hline & SS & $\begin{array}{l}\text { AY367480 } \\
\text { (SS1) } \\
\text { DQ364003 } \\
\text { (SS2) }\end{array}$ & 2 & $0.50 \%$ & $\begin{array}{l}2.1-2.4 \% \\
\text { with } \mathrm{M} 8\end{array}$ & $\begin{array}{c}\text { P. arizonae, } \\
\text { differ by } \\
4.5-6.1 \% \text {, } \\
\text { P. coloradensis, } \\
\text { differ by } 4.5 \%\end{array}$ & $\begin{array}{l}\text { Saratoga Spring, } \\
\text { Death Valley, San } \\
\text { Bernardino Co., CA }\end{array}$ & $\begin{array}{l}\text { Pyrgulopsis } \\
\text { sp. L HPL- } \\
2003 \text { in } \\
\text { GenBank }\end{array}$ \\
\hline $\begin{array}{l}\text { Pyrgulopsis } \\
\text { sathos }\end{array}$ & P62A & DQ364013 & 1 & $0.00 \%$ & & $\begin{array}{l}\text { P. hubbsi, } \\
\text { differ by } 1.0 \%\end{array}$ & $\begin{array}{l}\text { Flag Springs } \\
\text { (north), White River } \\
\text { Valley, Nye Co., NV }\end{array}$ & \\
\hline
\end{tabular}




\begin{tabular}{|c|c|c|c|c|c|c|c|c|}
\hline Species & $\begin{array}{l}\text { Published } \\
\text { Sample } \\
\text { Codes }\end{array}$ & $\begin{array}{l}\text { Accession } \\
\text { Numbers }\end{array}$ & $\begin{array}{c}\text { No. of } \\
\text { Specimens }(\mathrm{N})\end{array}$ & $\begin{array}{c}\text { Sequence } \\
\text { Variation } \\
\text { (\% pairwise } \\
\text { distance) }\end{array}$ & $\begin{array}{l}\text { Most Distant } \\
\text { Conspecific } \\
\text { Sequences (\%) }\end{array}$ & $\begin{array}{c}\text { Closest } \\
\text { Interspecific } \\
\text { Sequences (\%) }\end{array}$ & Collection Locality & Comments \\
\hline $\begin{array}{l}\text { Pyrgulopsis } \\
\text { saxatilis }\end{array}$ & P95A & AY627934 & 1 & $0.00 \%$ & & $\begin{array}{c}\text { P. eremica, } \\
\text { differ by } \\
6.6-9.4 \%, \\
\text { P. lentiglans, } \\
\text { differ by } 6.7 \% \\
\end{array}$ & $\begin{array}{l}\text { Warm Springs, } \\
\text { Snake Valley, } \\
\text { Millard Co., UT }\end{array}$ & \\
\hline $\begin{array}{l}\text { Pyrgulopsis } \\
\text { serrata }\end{array}$ & P69A & EU700464 & 1 & $0.00 \%$ & & $\begin{array}{c}\text { P. marcida, } \\
\text { differ by } 1.4 \%\end{array}$ & $\begin{array}{l}\text { Indian Ranch } \\
\text { Spring, Steptoe } \\
\text { Valley, White Pine } \\
\text { Co., NV }\end{array}$ & \\
\hline \multirow[t]{8}{*}{$\begin{array}{l}\text { Pyrgulopsis } \\
\text { similis }\end{array}$} & G4 & $\begin{array}{c}\text { KC571291 } \\
(N=4), \\
\text { KC571292 } \\
(N=1), \\
\text { KC571293 } \\
(N=1) \\
\text { KC571294 } \\
(N=1)\end{array}$ & 7 & $0-1.2 \%$ & $\begin{array}{l}0.5-1.5 \% \\
\text { with G6 }\end{array}$ & $\begin{array}{l}\text { P. marilynae, } \\
\text { differ by } \\
4.0-5.1 \%\end{array}$ & $\begin{array}{l}\text { Seepage along } \\
\text { Taylor Creek, ca. } \\
0.32 \mathrm{~km} \text { south, } \\
0.93 \mathrm{~km} \text { west of } \\
\text { Wall Lake Dam } \\
\text { (below Wall Lake), } \\
\text { Catron Co., NM }\end{array}$ & $\begin{array}{l}\text { P. gilae in } \\
\text { GenBank }\end{array}$ \\
\hline & G5 & KC571295 & 7 & $0.00 \%$ & $\begin{array}{l}1.1 \% \text { with G7, } \\
\text { G13, Pgil6 }\end{array}$ & $\begin{array}{l}\text { P. marilynae, } \\
\text { differ by } \\
3.8-4.1 \%\end{array}$ & $\begin{array}{l}\text { Hillside seep, } \\
1.61 \mathrm{~km} \text { north, } \\
0.97 \mathrm{~km} \text { east of } \\
\text { Burnt Corral } \\
\text { Canyon, Catron } \\
\text { Co., NM } \\
\end{array}$ & $\begin{array}{l}\text { P. gilae in } \\
\text { GenBank }\end{array}$ \\
\hline & G6 & $\begin{array}{c}\text { KC571296 } \\
(\mathrm{N}=2), \\
\text { KC571297 } \\
(\mathrm{N}=6) \\
\text { KC571298 } \\
(\mathrm{N}=1)\end{array}$ & 9 & $0-0.6 \%$ & $\begin{array}{c}1.2-1.5 \% \\
\text { with G7, G13, } \\
\text { Pgil6 }\end{array}$ & $\begin{array}{l}\text { P. marilynae, } \\
\text { differ by } \\
3.8-4.3 \%\end{array}$ & $\begin{array}{l}\text { Spring along } \\
\text { Beaver Creek, ca. } \\
0.29 \mathrm{~km} \text { north, } \\
0.40 \mathrm{~km} \text { west } \\
\text { of Taylor Creek } \\
\text { confluence, Catron } \\
\text { Co., NM }\end{array}$ & $\begin{array}{l}\text { P. gilae in } \\
\text { GenBank }\end{array}$ \\
\hline & G7 & KC571292 & 10 & $0.00 \%$ & $\begin{array}{l}1.2-1.5 \% \\
\text { with G6, } \\
1.2-1.4 \% \\
\text { with G9 }\end{array}$ & $\begin{array}{l}\text { P. marilynae, } \\
\text { differ by } \\
4.8-5.1 \%\end{array}$ & $\begin{array}{l}\text { Seepage along } \\
\text { Taylor Creek, } 50 \mathrm{~m} \\
\text { west of Whitetail } \\
\text { Canyon, Catron Co., } \\
\text { NM }\end{array}$ & $\begin{array}{l}P \text {. gilae in } \\
\text { GenBank }\end{array}$ \\
\hline & G9 & $\begin{array}{c}\text { KC571303 } \\
(N=1) \\
\text { KC571304 } \\
(N=8)\end{array}$ & 9 & $0-0.2 \%$ & $\begin{array}{c}1.2-1.4 \% \\
\text { with G7, G13, } \\
\text { Pgil6 }\end{array}$ & $\begin{array}{l}\text { P. marilynae, } \\
\text { differ by } \\
4.0-4.5 \%\end{array}$ & $\begin{array}{l}\text { Fall Spring, } \\
1.61 \mathrm{~km} \text { north, } \\
0.56 \mathrm{~km} \text { east of } \\
\text { Burnt Corral } \\
\text { Canyon, Catron } \\
\text { Co., NM } \\
\end{array}$ & $\begin{array}{l}P . \text { gilae in } \\
\text { GenBank }\end{array}$ \\
\hline & G10 & KC571304 & 4 & $0.00 \%$ & $\begin{array}{l}1.2 \% \text { with G7 } \\
\text { G13, Pgil6 }\end{array}$ & $\begin{array}{l}\text { P. marilynae, } \\
\text { differ by } \\
4.0-4.3 \%\end{array}$ & $\begin{array}{l}\text { Fall Spring, } \\
1.61 \mathrm{~km} \text { north, } \\
0.56 \mathrm{~km} \text { east of } \\
\text { Burnt Corral } \\
\text { Canyon, Catron } \\
\text { Co., NM }\end{array}$ & $\begin{array}{l}\text { P. gilae in } \\
\text { GenBank }\end{array}$ \\
\hline & $\mathrm{G} 13$ & KC571292 & 8 & $0.00 \%$ & $\begin{array}{l}1.2-1.5 \% \\
\text { with } \mathrm{G} 6 \\
1.2-1.4 \% \\
\text { with } \mathrm{G} 9\end{array}$ & $\begin{array}{l}\text { P. marilynae, } \\
\text { differ by } \\
4.8-5.1 \%\end{array}$ & $\begin{array}{l}\text { Spring along Taylor } \\
\text { Creek, } 0.81 \mathrm{~km} \\
\text { north, } 1.13 \mathrm{~km} \text { east } \\
\text { of Wall Lake Dam, } \\
\text { Catron Co., NM }\end{array}$ & $\begin{array}{l}P . \text { gilae in } \\
\text { GenBank }\end{array}$ \\
\hline & Pgil6 & AY485574 & 14 & $0.00 \%$ & $\begin{array}{l}1.2-1.5 \% \\
\text { with } \mathrm{G} 6 \\
1.2-1.4 \% \\
\text { with } \mathrm{G} 9\end{array}$ & $\begin{array}{l}\text { P. marilynae, } \\
\text { differ by } \\
4.8-5.1 \%\end{array}$ & Wall & $\begin{array}{l}\text { Hurt (2004), } \\
\text { P. gilae in } \\
\text { GenBank }\end{array}$ \\
\hline
\end{tabular}




\begin{tabular}{|c|c|c|c|c|c|c|c|c|}
\hline Species & $\begin{array}{l}\text { Published } \\
\text { Sample } \\
\text { Codes }\end{array}$ & $\begin{array}{l}\text { Accession } \\
\text { Numbers }\end{array}$ & $\begin{array}{c}\text { No. of } \\
\text { Specimens }(\mathrm{N})\end{array}$ & $\begin{array}{c}\text { Sequence } \\
\text { Variation } \\
\text { (\% pairwise } \\
\text { distance) }\end{array}$ & $\begin{array}{l}\text { Most Distant } \\
\text { Conspecific } \\
\text { Sequences (\%) }\end{array}$ & $\begin{array}{c}\text { Closest } \\
\text { Interspecific } \\
\text { Sequences (\%) }\end{array}$ & Collection Locality & Comments \\
\hline \multirow[t]{2}{*}{$\begin{array}{l}\text { Pyrgulopsis } \\
\text { simplex }\end{array}$} & P151A & AY627949 & 1 & $0.00 \%$ & $\begin{array}{l}0 \% \\
\text { with } \\
\text { Psim1 }\end{array}$ & $\begin{array}{l}\text { P. glandulosa, } \\
\text { differ by } \\
2.6-2.7 \% \text {, } \\
\text { P. perforata, } \\
\text { differ by } \\
2.6-2.7 \% \\
\end{array}$ & $\begin{array}{l}\text { Spring near } \\
\text { Strawberry, Verde } \\
\text { River drainage, Gila } \\
\text { Co., AZ }\end{array}$ & \\
\hline & Psim1 & AY485558 & 31 & $0.00 \%$ & $\begin{array}{c}0 \% \\
\text { with } \\
\text { P151A }\end{array}$ & $\begin{array}{c}\text { P. glandulosa, } \\
\text { differ by } 2.6- \\
2.7 \% \\
\text { P. perforata, } \\
\text { differ by } \\
2.6-2.7 \%\end{array}$ & Strawberry & Hurt (2004) \\
\hline \multirow[t]{2}{*}{$\begin{array}{l}\text { Pyrgulopsis } \\
\text { sola }\end{array}$} & BRSI & AY 627957 & 1 & $0.00 \%$ & $\begin{array}{l}0.2-0.4 \% \\
\text { with } \\
\text { Psol7/2/3 }\end{array}$ & $\begin{array}{l}\text { P. glandulosa, } \\
\text { differ by } 3.3 \% \text {, } \\
\text { P. intermdeia, } \\
\text { differ by } \\
3.3-3.9 \%\end{array}$ & $\begin{array}{l}\text { Brown Springs, } \\
\text { Verde River } \\
\text { drainage, Yavapai } \\
\text { Co., AZ }\end{array}$ & \\
\hline & $\begin{array}{l}\text { Psol1, } \\
\text { Psol2, } \\
\text { Psol3 }\end{array}$ & $\begin{array}{l}\text { AY } 485554 \\
(N=19), \\
\text { AY485555 } \\
(N=6), \\
\text { AY485556 } \\
(N=1)\end{array}$ & 26 & $0.2-0.4 \%$ & $\begin{array}{l}0.2-0.4 \% \\
\text { with BRS }\end{array}$ & $\begin{array}{l}\text { P. glandulosa, } \\
\text { differ by } \\
3.5-3.8 \% \\
\text { P. intermedia, } \\
\text { differ by } \\
3.5-4.3 \%\end{array}$ & Brown & $\begin{array}{l}\text { Hurt (2004), } \\
P . \text { solus in } \\
\text { GenBank }\end{array}$ \\
\hline \multirow[t]{9}{*}{$\begin{array}{l}\text { Pyrgulopsis } \\
\text { stearnsiana }\end{array}$} & $\begin{array}{c}16 / \\
\text { stearnsianaA } \\
\text { WC }\end{array}$ & AF520925 & 2 & $0.00 \%$ & $\begin{array}{l}3.6-3.7 \% \\
\text { with Pst8 }\end{array}$ & $\begin{array}{l}\text { P. diablensis, } \\
\text { differ by } 1.1 \%\end{array}$ & $\begin{array}{l}\text { Springs, Wildcat } \\
\text { Canyon, El } \\
\text { Sobrante, Contra } \\
\text { Costa Co., CA }\end{array}$ & \\
\hline & 18/PC/P26 & $\begin{array}{c}\text { AY367489 } \\
(P 26 A, N=1) \\
\text { GQ275092 } \\
(P 26 A A, N=1)\end{array}$ & 2 & $0.20 \%$ & $\begin{array}{l}3.2-3.7 \% \\
\text { with Pst8 }\end{array}$ & $\begin{array}{l}\text { P. diablensis, } \\
\text { differ by } \\
1.6-1.8 \%\end{array}$ & $\begin{array}{l}\text { Partington Creek, } \\
\text { Central California } \\
\text { coastal drainage, } \\
\text { Monterey Co., CA }\end{array}$ & \\
\hline & 19/CC/P28 & AY367490 & 3 & $0.00 \%$ & $\begin{array}{l}3.2-3.4 \% \\
\text { with Pst8 }\end{array}$ & $\begin{array}{l}\text { P. diablensis, } \\
\text { differ by } 1.1 \%\end{array}$ & $\begin{array}{l}\text { Stream in Colson } \\
\text { Canyon, Central } \\
\text { California coastal } \\
\text { drainage, Santa } \\
\text { Barbara Co., CA }\end{array}$ & \\
\hline & Pst1 & $K \times 398371$ & 4 & $0.00 \%$ & $\begin{array}{c}3.0-3.2 \% \\
\text { with Pst8 }\end{array}$ & $\begin{array}{l}\text { P. diablensis, } \\
\text { differ by } 1.7 \%\end{array}$ & $\begin{array}{l}\text { Spring run, Glen } \\
\text { Canyon Park, San } \\
\text { Francisco Co., CA }\end{array}$ & \\
\hline & Pst2 & $K \times 398372$ & 2 & $0.00 \%$ & $\begin{array}{l}3.0-3.2 \% \\
\text { with Pst8 }\end{array}$ & $\begin{array}{l}\text { P. diablensis, } \\
\text { differ by } 1.7 \%\end{array}$ & $\begin{array}{l}\text { Seep under the } \\
\text { connector between } \\
\text { Hwy } 280 \text { and Hwy } \\
\text { 101, San Francisco } \\
\text { Co., CA }\end{array}$ & \\
\hline & Pst3 & $\begin{array}{c}\mathrm{K} X 398373 \\
(N=4) \\
\mathrm{KX398374} \\
(\mathrm{N}=1)\end{array}$ & 5 & $0-0.2 \%$ & $\begin{array}{c}2.7-3.0 \% \\
\text { with Pst8 }\end{array}$ & $\begin{array}{l}\text { P. diablensis, } \\
\text { differ by } \\
0.9-1.1 \%\end{array}$ & $\begin{array}{l}\text { Spring north of } \\
\text { Laguna Honda, San } \\
\text { Francisco Co., CA }\end{array}$ & \\
\hline & Pst4 & $K \times 398375$ & 4 & $0.00 \%$ & $\begin{array}{c}3.6-3.8 \% \\
\text { with Pst8 }\end{array}$ & $\begin{array}{l}\text { P. diablensis, } \\
\text { differ by } 2.0 \%\end{array}$ & $\begin{array}{l}\text { Lobos Creek, San } \\
\text { Francisco Co., CA }\end{array}$ & \\
\hline & Pst5 & KX398376 & 4 & $0.00 \%$ & $\begin{array}{c}3.0-3.2 \% \\
\text { with Pst8 }\end{array}$ & $\begin{array}{l}\text { P. diablensis, } \\
\text { differ by } 1.7 \%\end{array}$ & $\begin{array}{l}\text { Spring along trail } \\
\text { northeast of Ft. } \\
\text { Miley, San } \\
\text { Francisco Co., CA }\end{array}$ & \\
\hline & Pst6 & KX398377 & 4 & $0.00 \%$ & $\begin{array}{c}2.8 \% \\
\text { with WC }\end{array}$ & $\begin{array}{l}\text { P. diablensis, } \\
\text { differ by } 0.6 \%\end{array}$ & $\begin{array}{l}\text { Spring north of } \\
\text { Geary Road, east } \\
\text { of Calaveras } \\
\text { Reservoir, } \\
\text { Alameda Co., CA }\end{array}$ & \\
\hline
\end{tabular}




\begin{tabular}{|c|c|c|c|c|c|c|c|c|}
\hline Species & $\begin{array}{l}\text { Published } \\
\text { Sample } \\
\text { Codes }\end{array}$ & $\begin{array}{l}\text { Accession } \\
\text { Numbers }\end{array}$ & $\begin{array}{c}\text { No. of } \\
\text { Specimens }(\mathrm{N})\end{array}$ & $\begin{array}{l}\text { Sequence } \\
\text { Variation } \\
\text { (\% pairwise } \\
\text { distance) }\end{array}$ & $\begin{array}{l}\text { Most Distant } \\
\text { Conspecific } \\
\text { Sequences (\%) }\end{array}$ & $\begin{array}{c}\text { Closest } \\
\text { Interspecific } \\
\text { Sequences (\%) }\end{array}$ & Collection Locality & Comments \\
\hline \multirow[t]{12}{*}{$\begin{array}{l}\text { Pyrgulopsis } \\
\text { stearnsiana } \\
\text { (continued) }\end{array}$} & Pst7 & $\begin{array}{c}K \times 398378 \\
(N=3) \\
K \times 398379 \\
(N=1)\end{array}$ & 4 & $0-1.2 \%$ & $\begin{array}{c}2.7-3.2 \% \\
\text { with Pst8 }\end{array}$ & $\begin{array}{l}\text { P. diablensis, } \\
\text { differ by } \\
0.6-1.1 \%\end{array}$ & $\begin{array}{l}\text { Spring north of } \\
\text { Geary Road, north } \\
\text { of Calaveras } \\
\text { Reservoir, Alameda } \\
\text { Co., CA }\end{array}$ & \\
\hline & Pst8 & $\begin{array}{c}\text { KX398380 } \\
(N=3) \\
\text { KX398381 } \\
(N=1)\end{array}$ & 4 & $0-0.2 \%$ & $\begin{array}{c}3.6-3.8 \% \\
\text { with Pst4, } \\
3.0-3.8 \% \\
\text { with Pst13, } \\
3.3-3.8 \% \\
\text { with Pst 15, } \\
3.6-3.8 \% \\
\text { with WC, } \\
3.2-3.7 \% \\
\text { with PC }\end{array}$ & $\begin{array}{l}\text { P. diablensis, } \\
\text { differ by } \\
2.7-2.8 \%\end{array}$ & $\begin{array}{l}\text { Spring south } \\
\text { of Geary Road, } \\
\text { northeast of } \\
\text { Calaveras } \\
\text { Reservoir, Alameda } \\
\text { Co., CA }\end{array}$ & \\
\hline & Pst9 & KX398382 & 5 & $0.00 \%$ & $\begin{array}{c}3.5 \% \text { with Pst4, } \\
2.9-3.5 \% \\
\text { with Pst13, } \\
3.2-3.5 \% \\
\text { with Pst } 15 \text {, } \\
3.4 \% \text { with WC } \\
3.0-3.4 \% \\
\text { with PC }\end{array}$ & $\begin{array}{l}\text { P. diablensis, } \\
\text { differ by } 2.5 \%\end{array}$ & $\begin{array}{l}\text { Spring along } \\
\text { Weller Road, west } \\
\text { of Calaveras } \\
\text { Reservoir, Santa } \\
\text { Clara Co., CA }\end{array}$ & \\
\hline & Pst10 & $\begin{array}{c}K \times 398383 \\
(N=1) \\
K \times 398384 \\
(N=1)\end{array}$ & 2 & $0.60 \%$ & $\begin{array}{l}2.4-2.9 \% \text { with } \\
\text { Pst8 }\end{array}$ & $\begin{array}{l}\text { P. diablensis, } \\
\text { differ by } \\
1.1-1.4 \%\end{array}$ & $\begin{array}{l}\text { Temescal Creek, } \\
\text { Alameda Co., CA }\end{array}$ & \\
\hline & Pst11 & KX398385 & 4 & $0.00 \%$ & $\begin{array}{c}2.9-3.0 \% \\
\text { with Pst8 }\end{array}$ & $\begin{array}{l}\text { P. diablensis, } \\
\text { differ by } 0.9 \%\end{array}$ & $\begin{array}{l}\text { Spring tributary to } \\
\text { northeast corner } \\
\text { of Rodeo Lagoon, } \\
\text { Marin Co., CA }\end{array}$ & \\
\hline & Pst12 & $\begin{array}{c}K \times 398386 \\
(N=3) \\
K \times 398387 \\
(N=1)\end{array}$ & 4 & $0-2.4 \%$ & $\begin{array}{c}2.6-2.9 \% \text { with } \\
\text { Pst8, 2.5-3.0\% } \\
\text { with WC }\end{array}$ & $\begin{array}{l}\text { P. diablensis, } \\
\text { differ by } \\
1.0-1.1 \%\end{array}$ & $\begin{array}{l}\text { McWay Creek, } \\
\text { Monterey Co., CA }\end{array}$ & \\
\hline & Pst13 & $\begin{array}{c}K \times 398388 \\
(N=1) \\
K \times 398389 \\
(N=3)\end{array}$ & 4 & $0-0.9 \%$ & $\begin{array}{c}3.0-3.8 \% \text { with } \\
\text { Pst8, 2.9-3.5\% } \\
\text { with Pst9 }\end{array}$ & $\begin{array}{l}\text { P. diablensis, } \\
\text { differ by } \\
0.8-1.4 \%\end{array}$ & $\begin{array}{l}\text { Spring at Seven } \\
\text { Stairs, Monterey } \\
\text { Co., CA }\end{array}$ & \\
\hline & Pst1 4 & KX398390 & 4 & $0.00 \%$ & $\begin{array}{c}3.0-3.2 \% \\
\text { with Pst8 }\end{array}$ & $\begin{array}{l}\text { P. diablensis, } \\
\text { differ by } 0.8 \%\end{array}$ & $\begin{array}{l}\text { Stream south of } \\
\text { Salmon Creek, } \\
\text { Monterey Co., CA }\end{array}$ & \\
\hline & Pst15 & $\begin{array}{c}K \times 398391 \\
(N=2) \\
K \times 398392 \\
(N=2)\end{array}$ & 4 & $0-0.3 \%$ & $\begin{array}{c}\text { 3.3-3.8\% with } \\
\text { Pst8, 3.2-3.5\% } \\
\text { with Pst9 }\end{array}$ & $\begin{array}{l}\text { P. diablensis, } \\
\text { differ by } \\
1.1-1.4 \%\end{array}$ & $\begin{array}{l}\text { Springs southeast } \\
\text { of Leffingwell } \\
\text { Creek, San Luis } \\
\text { Obispo Co., CA }\end{array}$ & \\
\hline & Pst16 & $\begin{array}{c}K \times 398393 \\
(N=2) \\
K \times 398394 \\
(N=2)\end{array}$ & 4 & $0-1.5 \%$ & $\begin{array}{l}2.6-3.2 \% \text { with } \\
\text { Pst } 8,2.4-2.9 \% \\
\text { with Pst9, 2.6- } \\
3.0 \% \text { with WC }\end{array}$ & $\begin{array}{l}\text { P. diablensis, } \\
\text { differ by } \\
1.7-1.4 \%\end{array}$ & $\begin{array}{l}\text { San Miguelito } \\
\text { Creek, Santa } \\
\text { Barbara Co., CA }\end{array}$ & \\
\hline & Pst17 & KX398395 & 4 & $0.00 \%$ & $\begin{array}{l}3.2-3.3 \% \\
\text { with Pst8 }\end{array}$ & $\begin{array}{l}\text { P. giulianii, differ } \\
\text { by } 1.6-1.7 \%\end{array}$ & $\begin{array}{l}\text { Stream at Hilarita, } \\
\text { Marin Co., CA }\end{array}$ & \\
\hline & Pst18 & KX398396 & 4 & $0.00 \%$ & $\begin{array}{l}3.2-3.3 \% \\
\text { with Pst8 }\end{array}$ & $\begin{array}{l}\text { P. diablensis, } \\
\text { differ by } 1.3 \%\end{array}$ & $\begin{array}{l}\text { Seep south of } \\
\text { Stinson Beach, } \\
\text { Marin Co., CA }\end{array}$ & \\
\hline $\begin{array}{l}\text { Pyrgulopsis } \\
\text { sterilis }\end{array}$ & & AY367491 & 1 & $0.00 \%$ & & $\begin{array}{l}\text { P. marcida, } \\
\text { differ by } 1.4 \%\end{array}$ & $\begin{array}{l}\text { Spring, Hunts } \\
\text { Canyon Ranch, } \\
\text { Ralston Valley, Nye } \\
\text { Co., NV }\end{array}$ & \\
\hline
\end{tabular}




\begin{tabular}{|c|c|c|c|c|c|c|c|c|}
\hline Species & $\begin{array}{l}\text { Published } \\
\text { Sample } \\
\text { Codes }\end{array}$ & $\begin{array}{l}\text { Accession } \\
\text { Numbers }\end{array}$ & $\begin{array}{c}\text { No. of } \\
\text { Specimens }(\mathrm{N})\end{array}$ & $\begin{array}{l}\text { Sequence } \\
\text { Variation } \\
\text { (\% pairwise } \\
\text { distance) }\end{array}$ & $\begin{array}{l}\text { Most Distant } \\
\text { Conspecific } \\
\text { Sequences (\%) }\end{array}$ & $\begin{array}{c}\text { Closest } \\
\text { Interspecific } \\
\text { Sequences (\%) }\end{array}$ & Collection Locality & Comments \\
\hline $\begin{array}{l}\text { Pyrgulopsis } \\
\text { sublata }\end{array}$ & P111A & AY627938 & 1 & $0.00 \%$ & & $\begin{array}{l}\text { P. leporina, } \\
\text { differ by } 1.9 \%\end{array}$ & $\begin{array}{l}\text { Wambolt Springs, } \\
\text { Lake Valley, Lincoln } \\
\text { Co., NV }\end{array}$ & \\
\hline $\begin{array}{l}\text { Pyrgulopsis } \\
\text { sulcata }\end{array}$ & P66A & AY627929 & 1 & $0.00 \%$ & & $\begin{array}{l}\text { P. neritel/a, } \\
\text { differ by } 3.2 \%\end{array}$ & $\begin{array}{l}\text { Spring northwest } \\
\text { of Clark Spring, } \\
\text { Steptoe Valley, } \\
\text { White Pine Co., NV }\end{array}$ & \\
\hline $\begin{array}{c}\text { Pyrgulopsis } \\
\text { taylori }\end{array}$ & P27 & $\begin{array}{c}\text { AY627923 } \\
(P 27 A, N=1) \\
\text { GQ275095 } \\
(P 27 A A, N=3)\end{array}$ & 4 & $0-0.3 \%$ & & $\begin{array}{c}\text { P. bacchus, } \\
\text { differ by } \\
4.0-4.5 \% \text {, } \\
\text { P. milleri, } \\
\text { differ by } \\
3.7-4.0 \% \text {, } \\
\text { P. montana, } \\
\text { differ by } \\
3.7-4.0 \% \text {, } \\
\text { P. turbatrix, } \\
\text { differ by } \\
3.0-6.9 \%\end{array}$ & $\begin{array}{l}\text { Spring tributary to } \\
\text { San Luis Obispo } \\
\text { Creek, California } \\
\text { central coastal } \\
\text { drainage, San Luis } \\
\text { Obispo Co., CA }\end{array}$ & \\
\hline \multirow[t]{4}{*}{$\begin{array}{c}\text { Pyrgulopsis } \\
\text { thermalis }\end{array}$} & P165A & AY627953 & 1 & $0.00 \%$ & $\begin{array}{l}2.7-3.2 \% \text { with } \\
\text { Pthe } 3 / 4 / 5 / 6 / 7\end{array}$ & $\begin{array}{l}\text { P. lockensis, } \\
\text { differ by } 7.3 \%\end{array}$ & $\begin{array}{l}\text { Hot Spring, Gila } \\
\text { River drainage, } \\
\text { Grant Co., NM }\end{array}$ & \\
\hline & $\begin{array}{l}\text { Pthe1, } \\
\text { Pthe2 }\end{array}$ & $\begin{array}{l}\text { AY } 485575 \\
(N=30) \\
\text { AY } 485576 \\
(N=1)\end{array}$ & 31 & $0-0.3 \%$ & $\begin{array}{l}2.7-2.7 \% \text { with } \\
\text { Pthe } 3 / 4 / 5 / 6 / 7\end{array}$ & $\begin{array}{c}\text { P. deaconi, differ } \\
\text { by } 7.7-7.7 \%, \\
\text { P. lockensis, } \\
\text { differ by } 7.5- \\
7.8 \% \\
\text { P. trivialis, differ } \\
\text { by } 7.3-7.8 \% \text {, } \\
\end{array}$ & Gila I & Hurt (2004) \\
\hline & $\begin{array}{l}\text { Pthe3, } \\
\text { Pthe4, } \\
\text { Pthe5, } \\
\text { Pthe6, } \\
\text { Pthe7 }\end{array}$ & $\begin{array}{c}\text { AY } 485577 \\
(N=1), \\
\text { AY485578 } \\
(N=1), \\
\text { AY } 485579 \\
(N=1), \\
\text { AY485580 } \\
(N=1), \\
\text { AY485581 } \\
(N=1)\end{array}$ & 5 & $0.2-0.9 \%$ & $\begin{array}{c}2.7-3.2 \% \\
\text { with P165, } \\
2.7-3.6 \% \text { with } \\
\text { Pthe8/9/10/17 }\end{array}$ & $\begin{array}{l}\text { P. carinifera, } \\
\text { differ by } \\
6.4-7.0 \%\end{array}$ & Gila II & Hurt (2004) \\
\hline & $\begin{array}{l}\text { Pthe8, } \\
\text { Pthe9, } \\
\text { Pthe10, } \\
\text { Pthe11 }\end{array}$ & $\begin{array}{c}\text { AY } 485582 \\
(N=?), \\
\text { AY485583 } \\
(N=?), \\
\text { AY485584 } \\
(N=?), \\
\text { AY485585 } \\
(N=?)\end{array}$ & 31 & $0.0-0.8 \%$ & $\begin{array}{l}2.7-3.6 \% \text { with } \\
\text { Pthe } 3 / 4 / 5 / 6 / 7\end{array}$ & $\begin{array}{c}\text { P. kolobensis, } \\
\text { differ by, } \\
7.7-8.9 \% \text {, } \\
\text { P. lockensis, } \\
\text { differ by } \\
7.3-8.3 \% \text {, } \\
\text { P. trivialis, differ } \\
\text { by } 7.7-9.4 \% \text {, } \\
\text { P. wongi, differ } \\
\text { by } 7.7-10.5 \%\end{array}$ & Gila III & $\begin{array}{l}\text { Hurt (2004), } \\
\text { listed } \\
\text { frequency } \\
\text { greater than } \\
1.0(1.582)\end{array}$ \\
\hline \multirow[t]{2}{*}{$\begin{array}{l}\text { Pyrgulopsis } \\
\text { thompsoni }\end{array}$} & Pthol & AY 485588 & 32 & $0.00 \%$ & $\begin{array}{l}2.5 \% \text { with } \\
\text { Ptho5 }\end{array}$ & $\begin{array}{l}\text { P. conica, differ } \\
\text { by } 3.2 \% \text {, } \\
\text { P. glandulosa, } \\
\text { differ by } \\
3.2-3.3 \% \text {, } \\
\text { P. morrisoni, } \\
\text { differ by } \\
2.9-4.6 \%\end{array}$ & Bear & Hurt (2004) \\
\hline & $\begin{array}{l}\text { Pthol, } \\
\text { Ptho2 }\end{array}$ & $\begin{array}{l}\text { AY 485588 } \\
(N=29) \\
\text { AY 485589 } \\
(N=1)\end{array}$ & 30 & $0.00 \%$ & $\begin{array}{l}2.5 \% \text { with } \\
\text { Ptho5 }\end{array}$ & $\begin{array}{l}\text { P. conica, differ } \\
\text { by } 3.2 \% \text {, } \\
\text { P. glandulosa, } \\
\text { differ by } \\
3.2-3.3 \% \\
\text { P. morrisoni, } \\
\text { differ by } \\
2.9-4.6 \%\end{array}$ & Canelo Hills & $\begin{array}{l}\text { Hurt (2004), } \\
\text { No variation } \\
\text { between } \\
\text { Ptho1 and } \\
\text { Ptho } 2 \text { in } \\
\text { GenBank }\end{array}$ \\
\hline
\end{tabular}




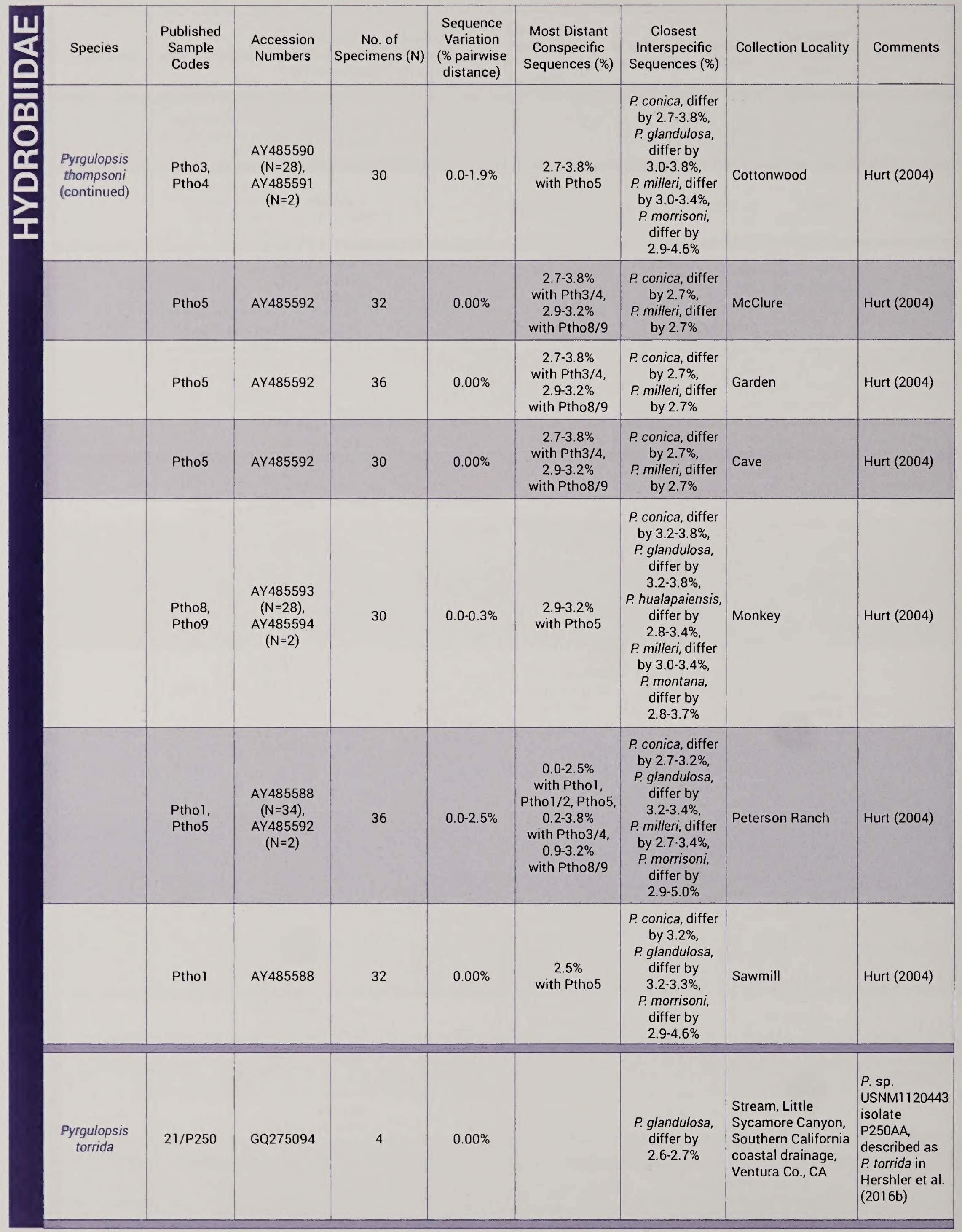




\begin{tabular}{|c|c|c|c|c|c|c|c|c|}
\hline Species & $\begin{array}{c}\text { Published } \\
\text { Sample } \\
\text { Codes }\end{array}$ & $\begin{array}{l}\text { Accession } \\
\text { Numbers }\end{array}$ & $\begin{array}{c}\text { No. of } \\
\text { Specimens (N) }\end{array}$ & $\begin{array}{c}\text { Sequence } \\
\text { Variation } \\
\text { (\% pairwise } \\
\text { distance) }\end{array}$ & $\begin{array}{l}\text { Most Distant } \\
\text { Conspecific } \\
\text { Sequences (\%) }\end{array}$ & $\begin{array}{c}\text { Closest } \\
\text { Interspecific } \\
\text { Sequences (\%) }\end{array}$ & Collection Locality & Comments \\
\hline $\begin{array}{c}\text { Pyrgulopsis } \\
\text { transversa }\end{array}$ & P112A & EU700470 & 1 & $0.00 \%$ & & $\begin{array}{c}\text { P. kolobensis, } \\
\text { differ by } \\
0.6-2.7 \% \text {, } \\
\text { P. nonaria, differ } \\
\text { by } 1.1 \% \text {, } \\
\text { P. pilsbryana, } \\
\text { differ by } \\
1.0-1.1 \% \text {, } \\
\text { P. sp. C, differ } \\
\text { by } 1.1 \% \text {, } \\
\text { P. sp. D, differ } \\
\text { by } 1 \% \text {, } \\
\text { P. sp. H. differ } \\
\text { by } 1.1 \%\end{array}$ & $\begin{array}{l}\text { Sixmile Springs, } \\
\text { Old River Bed, } \\
\text { Tooele Co., UT }\end{array}$ & \\
\hline \multirow[t]{3}{*}{$\begin{array}{c}\text { Pyrgulopsis } \\
\text { trivialis }\end{array}$} & P119A & AY627941 & 1 & $0.00 \%$ & $0.3 \%$ with Ptri 1 & $\begin{array}{c}\text { P. kolobensis, } \\
\text { differ by } \\
3.1-4.4 \% \text {, } \\
\text { P. nonaria, differ } \\
\text { by } 3.6 \% \text {, } \\
\text { P. pilsbryana, } \\
\text { differ by } 3.6 \% \text {, } \\
\text { P. variegata, } \\
\text { differ by } 3.7 \% \text {, } \\
\text { P. sp. C, differ } \\
\text { by } 3.6-3.7 \% \text {, } \\
\text { P. sp. D, differ } \\
\text { by } 3.6 \% \\
\text { P. sp. H, differ } \\
\text { by } 3.6 \%\end{array}$ & $\begin{array}{l}\text { Spring, Three Forks, } \\
\text { Gila River drainage, } \\
\text { Apache Co., AZ }\end{array}$ & \\
\hline & Ptril & $\begin{array}{c}\text { AY } 485559 \\
(N=31)\end{array}$ & 31 & $0.00 \%$ & $0.5 \%$ with Ptri 2 & $\begin{array}{c}\text { P. kolobensis, } \\
\text { differ by } \\
3.3-4.8 \% \text {, } \\
\text { P. nonaria, } \\
\text { differ } 3.8 \% \text {, } \\
\text { P. pilsbryana, } \\
\text { differ by } 3.9 \% \text {, } \\
\text { P. variegata, } \\
\text { differ by } 4.0 \% \text {, } \\
\text { P. sp. C, differ } \\
\text { by } 3.8-4.0 \% \text {, } \\
\text { P. sp. D, differ } \\
\text { by } 3.9 \% \text {, } \\
\text { P. sp. H, differ } \\
\text { by } 3.9 \%\end{array}$ & Boneyard Bog & Hurt (2004) \\
\hline & Ptri2 & $\begin{array}{l}\text { AY } 485560 \\
(N=31)\end{array}$ & 31 & $0.00 \%$ & $0.5 \%$ with Ptril & $\begin{array}{c}\text { P. kolobensis, } \\
\text { differ by } \\
3.2-4.7 \% \text {, } \\
\text { P. nonaria, } \\
\text { differ by } 3.6 \% \text {, } \\
\text { P. pilsbryana, } \\
\text { differ by } 3.7 \% \text {, } \\
\text { P. variegata, } \\
\text { differ by } 3.9 \% \text {, } \\
\text { P. sp. C. differ } \\
\text { by } 3.6-3.9 \% \text {, } \\
\text { P. sp. D, } \\
\text { differ by } 3.7 \% \\
\text { P. sp. H, } \\
\text { differ by } 3.7 \%\end{array}$ & Three Forks & Hurt (2004) \\
\hline
\end{tabular}




\begin{tabular}{|c|c|c|c|c|c|c|c|c|}
\hline Species & $\begin{array}{l}\text { Published } \\
\text { Sample } \\
\text { Codes }\end{array}$ & $\begin{array}{l}\text { Accession } \\
\text { Numbers }\end{array}$ & $\begin{array}{c}\text { No. of } \\
\text { Specimens }(\mathrm{N})\end{array}$ & $\begin{array}{l}\text { Sequence } \\
\text { Variation } \\
\text { (\% pairwise } \\
\text { distance) }\end{array}$ & $\begin{array}{l}\text { Most Distant } \\
\text { Conspecific } \\
\text { Sequences (\%) }\end{array}$ & $\begin{array}{c}\text { Closest } \\
\text { Interspecific } \\
\text { Sequences (\%) }\end{array}$ & Collection Locality & Comments \\
\hline \multirow[t]{14}{*}{$\begin{array}{l}\text { Pyrgulopsis } \\
\text { turbatrix }\end{array}$} & M9 & $\begin{array}{l}\text { AY367441 } \\
\text { (M9A), } \\
\text { AY367442 } \\
\text { (M9B) }\end{array}$ & 2 & $0.00 \%$ & $\begin{array}{c}1.3 \% \\
\text { with } \mathrm{M} 19 \\
\text { P11 }\end{array}$ & $\begin{array}{l}\text { P. imperialis, } \\
\text { differ by } 5.2 \%\end{array}$ & $\begin{array}{l}\text { Stream below } \\
\text { Darwin Falls, } \\
\text { Panamint Valley, } \\
\text { Inyo Co., CA }\end{array}$ & $\begin{array}{l}\text { P. micrococcus } \\
\text { in GenBank }\end{array}$ \\
\hline & M10 & $\begin{array}{l}\text { AY367443 } \\
(\mathrm{M} 10 \mathrm{~A}) \\
\text { AY367444 } \\
\text { (M10B) }\end{array}$ & 2 & $0.00 \%$ & $\begin{array}{l}1.4 \% \\
\text { with } \mathrm{M} 19 \\
\text { P11 }\end{array}$ & $\begin{array}{l}\text { P. imperialis, } \\
\text { differ by } 5.2 \%\end{array}$ & $\begin{array}{l}\text { China Garden } \\
\text { Spring, Panamint } \\
\text { Valley, Inyo Co., CA }\end{array}$ & $\begin{array}{l}\text { P. micrococcus } \\
\text { in GenBank }\end{array}$ \\
\hline & M11 & AY367445 & 1 & $0.00 \%$ & $\begin{array}{c}1.4 \% \\
\text { with M19, P11. } \\
\text { P85, P196 }\end{array}$ & $\begin{array}{l}\text { P. imperialis, } \\
\text { differ by } 5.2 \%\end{array}$ & $\begin{array}{l}\text { Spring above } \\
\text { Darwin Falls, } \\
\text { Panamint Valley, } \\
\text { Inyo Co., CA } \\
\end{array}$ & $\begin{array}{l}P . \text { micrococcus } \\
\text { in GenBank }\end{array}$ \\
\hline & M12 & $\begin{array}{l}\text { AY367446 } \\
(M 12 A) \\
\text { AY367447 } \\
\text { (M12B) }\end{array}$ & 2 & $0.00 \%$ & $\begin{array}{c}1.4 \% \\
\text { with P11, } \\
\text { P196 }\end{array}$ & $\begin{array}{l}\text { P. imperialis, } \\
\text { differ by } 5.0 \%\end{array}$ & $\begin{array}{l}\text { Lower spring, } \\
\text { Johnson Canyon, } \\
\text { Death Valley, Inyo } \\
\text { Co., CA }\end{array}$ & $\begin{array}{l}\text { P. micrococcus } \\
\text { in GenBank }\end{array}$ \\
\hline & M13 & $\begin{array}{c}\text { AY367448/ } \\
\text { AY367450-52 } \\
\text { (N=4, } \\
\text { M13A, C-E), } \\
\text { AY367449 } \\
\text { (M13B), } \\
\text { AY367453 } \\
\text { (M13F) }\end{array}$ & 6 & $0-0.3 \%$ & $\begin{array}{l}1.4-1.6 \% \\
\text { with P11, } \\
\text { P196 }\end{array}$ & $\begin{array}{l}\text { P. imperialis, } \\
\text { differ by } \\
5.0-5.2 \%\end{array}$ & $\begin{array}{l}\text { Stream, Hanaupah } \\
\text { Canyon, Death } \\
\text { Valley, Inyo Co., CA }\end{array}$ & $\begin{array}{l}\text { P. micrococcus } \\
\text { in GenBank }\end{array}$ \\
\hline & M14 & $\begin{array}{l}\text { AY367454 } \\
(\text { M 14A) } \\
\text { AY367455 } \\
\text { (M14B) }\end{array}$ & 2 & $0.20 \%$ & $\begin{array}{l}1.4-1.6 \% \\
\text { with P11, } \\
\text { P196 }\end{array}$ & $\begin{array}{l}\text { P. imperialis, } \\
\text { differ by } \\
5.0-5.2 \%\end{array}$ & $\begin{array}{l}\text { Stream, Jail } \\
\text { Canyon, Panamint } \\
\text { Valley, Inyo Co., CA }\end{array}$ & $\begin{array}{l}\text { P. micrococcus } \\
\text { in GenBank }\end{array}$ \\
\hline & M15 & $\begin{array}{c}\text { AY367456 } \\
\text { (M15A, M15M), } \\
\text { AY367457 } \\
\text { (M15B) }\end{array}$ & 3 & $0.20 \%$ & $\begin{array}{l}1.8-1.9 \% \\
\text { with P11, } \\
\text { P196 }\end{array}$ & $\begin{array}{l}\text { P. imperialis, } \\
\text { differ by } \\
5.2-5.3 \%\end{array}$ & $\begin{array}{l}\text { Stream, Hall } \\
\text { Canyon, Panamint } \\
\text { Valley, Inyo Co., CA }\end{array}$ & $\begin{array}{l}\text { P. micrococcus } \\
\text { in GenBank }\end{array}$ \\
\hline & M16 & $\begin{array}{c}\text { AY367458 } \\
\text { (M16A, M16M) }\end{array}$ & 2 & $0.00 \%$ & $\begin{array}{c}2.1 \% \\
\text { with P11, } \\
\text { P86, P196 }\end{array}$ & $\begin{array}{l}\text { P. imperialis, } \\
\text { differ by } 5.5 \%\end{array}$ & $\begin{array}{l}\text { Spring, Snow } \\
\text { Canyon, Panamint } \\
\text { Valley, Inyo Co., CA }\end{array}$ & $\begin{array}{l}\text { P. micrococcus } \\
\text { in GenBank }\end{array}$ \\
\hline & M17 & AY367459 & 1 & $0.00 \%$ & $\begin{array}{l}2.1 \% \\
\text { with P11, } \\
\text { P196 }\end{array}$ & $\begin{array}{l}\text { P. imperialis, } \\
\text { differ by } 5.5 \%\end{array}$ & $\begin{array}{l}\text { Cottonwood Spring, } \\
\text { Wildrose Canyon, } \\
\text { Panamint Valley, } \\
\text { Inyo Co., CA }\end{array}$ & $\begin{array}{l}\text { P. micrococcus } \\
\text { in GenBank }\end{array}$ \\
\hline & M18 & $\begin{array}{c}\text { AY367460 } \\
\text { (M18A, M180) }\end{array}$ & 2 & $0.00 \%$ & $\begin{array}{c}2.1 \% \\
\text { with P11, } \\
\text { P196 }\end{array}$ & $\begin{array}{l}\text { P. imperialis, } \\
\text { differ by } \\
5.3-5.5 \%\end{array}$ & $\begin{array}{l}\text { Saline Marsh, } \\
\text { Saline Valley, Inyo } \\
\text { Co., CA }\end{array}$ & $\begin{array}{l}\text { P. micrococcus } \\
\text { in GenBank }\end{array}$ \\
\hline & M19 & $\begin{array}{c}\text { AY367461 } \\
\text { (M19A, M190) }\end{array}$ & 2 & $0.00 \%$ & $\begin{array}{c}1.8 \% \\
\text { with M16 }\end{array}$ & $\begin{array}{l}\text { P. imperialis, } \\
\text { differ by } 5.5 \%\end{array}$ & $\begin{array}{l}\text { Cushenbury Springs, } \\
\text { San Bernardino } \\
\text { Mountains, San } \\
\text { Bernardino Co., CA }\end{array}$ & $\begin{array}{l}\text { P. micrococcus } \\
\text { in GenBank }\end{array}$ \\
\hline & M20 & $\begin{array}{c}\text { AY367462 } \\
(\mathrm{M} 20 \mathrm{~A}, \mathrm{M} 20 \mathrm{~N})\end{array}$ & 2 & $0.00 \%$ & $\begin{array}{l}1.6 \% \\
\text { with P11. } \\
\text { P196 }\end{array}$ & $\begin{array}{l}\text { P. imperialis, } \\
\text { differ by } 5.2 \%\end{array}$ & $\begin{array}{l}\text { Springs at Big Bear } \\
\text { Ranger Station, } \\
\text { San Bernardino } \\
\text { Mountains, San } \\
\text { Bernardino Co., CA }\end{array}$ & $\begin{array}{l}\text { P. micrococcus } \\
\text { in GenBank }\end{array}$ \\
\hline & M21 & $\begin{array}{c}\text { AY367463 } \\
\text { (M21A, M21M), } \\
\text { AY367464 } \\
\text { (M21B) }\end{array}$ & 3 & $0.00 \%$ & $\begin{array}{c}1.6 \% \\
\text { with M16 }\end{array}$ & $\begin{array}{l}\text { P. imperialis, } \\
\text { differ by } 5.3 \%\end{array}$ & $\begin{array}{l}\text { Springs, Mill } \\
\text { Creek Canyon, } \\
\text { San Bernardino } \\
\text { Mountains, San } \\
\text { Bernardino Co., CA }\end{array}$ & $\begin{array}{l}\text { P. micrococcus } \\
\text { in GenBank }\end{array}$ \\
\hline & M22 & $\begin{array}{c}\text { AY367465/ } \\
\text { AY367466 } \\
(N=2, M 22 A-B), \\
\text { AY367467 } \\
(M 22 C)\end{array}$ & 3 & $0.20 \%$ & $\begin{array}{l}1.4-1.6 \% \\
\text { with P11, } \\
\text { P196 }\end{array}$ & $\begin{array}{l}\text { P. imperialis, } \\
\text { differ by } \\
5.0-5.2 \%\end{array}$ & $\begin{array}{l}\text { Spring, Knight } \\
\text { Canyon, Panamint } \\
\text { Valley, Inyo Co., CA }\end{array}$ & $\begin{array}{l}\text { P. micrococcus } \\
\text { in GenBank }\end{array}$ \\
\hline
\end{tabular}




\begin{tabular}{|c|c|c|c|c|c|c|c|c|}
\hline Species & $\begin{array}{l}\text { Published } \\
\text { Sample } \\
\text { Codes }\end{array}$ & $\begin{array}{l}\text { Accession } \\
\text { Numbers }\end{array}$ & $\begin{array}{c}\text { No. of } \\
\text { Specimens }(\mathrm{N})\end{array}$ & $\begin{array}{l}\text { Sequence } \\
\text { Variation } \\
\text { (\% pairwise } \\
\text { distance) }\end{array}$ & $\begin{array}{l}\text { Most Distant } \\
\text { Conspecific } \\
\text { Sequences (\%) }\end{array}$ & $\begin{array}{c}\text { Closest } \\
\text { Interspecific } \\
\text { Sequences (\%) }\end{array}$ & Collection Locality & Comments \\
\hline \multirow[t]{7}{*}{$\begin{array}{l}\text { Pyrgulopsis } \\
\text { turbatrix } \\
\text { (continued) }\end{array}$} & M24 & $\begin{array}{c}\text { AY367468 } \\
(\mathrm{M} 24 \mathrm{~A}, \mathrm{M} 24 \mathrm{~N})\end{array}$ & 2 & $0.00 \%$ & $\begin{array}{c}1.4 \% \text { with P1 1, } \\
\text { P196 }\end{array}$ & $\begin{array}{l}\text { P. imperialis, } \\
\text { differ by } 5.0 \%\end{array}$ & $\begin{array}{l}\text { Tennessee Spring, } \\
\text { Panamint Valley, } \\
\text { Inyo Co., CA }\end{array}$ & $\begin{array}{l}\text { P. micrococcus } \\
\text { in GenBank }\end{array}$ \\
\hline & M27 & AY367474 & 1 & $0.00 \%$ & $\begin{array}{c}1.4 \% \text { with P1 } 1 \\
\text { P196 }\end{array}$ & $\begin{array}{l}\text { P. imperialis, } \\
\text { differ by } 5.0 \%\end{array}$ & $\begin{array}{l}\text { Stream below } \\
\text { Limekiln Spring, } \\
\text { Panamint Valley, } \\
\text { Inyo Co., CA }\end{array}$ & $\begin{array}{l}\text { P. micrococcus } \\
\text { in GenBank }\end{array}$ \\
\hline & M28 & AY367475 & 1 & $0.00 \%$ & $\begin{array}{c}1.4 \% \text { with P11, } \\
\text { P196 }\end{array}$ & $\begin{array}{l}\text { P. imperialis, } \\
\text { differ by } 5.0 \%\end{array}$ & $\begin{array}{l}\text { Brewery Spring, } \\
\text { Surprise Canyon, } \\
\text { Panamint Valley, } \\
\text { Inyo Co., CA }\end{array}$ & $\begin{array}{l}\text { P. micrococcus } \\
\text { in GenBank }\end{array}$ \\
\hline & P11 & $\begin{array}{l}\text { AF520936 } \\
(\mathrm{P} 11 \mathrm{~A})\end{array}$ & 1 & $0.00 \%$ & $\begin{array}{c}2.1 \% \text { with M16, } \\
\text { M17, M18 }\end{array}$ & $\begin{array}{l}\text { P. imperialis, } \\
\text { differ by } 5.2 \%\end{array}$ & $\begin{array}{l}\text { Horseshutem } \\
\text { Springs, Pahrump } \\
\text { Valley, Nye Co., NV }\end{array}$ & \\
\hline & P84 & $\begin{array}{l}\text { DQ364014 } \\
(\text { P84A) }\end{array}$ & 1 & $0.00 \%$ & $\begin{array}{c}1.9 \% \text { with } \mathrm{M} 16 \\
\mathrm{M} 7 \mathrm{~T}, \mathrm{M} 18\end{array}$ & $\begin{array}{l}\text { P. imperialis, } \\
\text { differ by } 5.0 \%\end{array}$ & $\begin{array}{l}\text { Cold Creek Spring, } \\
\text { Indian Springs } \\
\text { Valley, Clark Co., NV }\end{array}$ & \\
\hline & P86 & $\begin{array}{l}\text { DQ364015 } \\
(\text { P86A) }\end{array}$ & 1 & $0.00 \%$ & $2.1 \%$ with $\mathrm{M} 16$ & $\begin{array}{l}\text { P. imperialis, } \\
\text { differ by } 5.2 \%\end{array}$ & $\begin{array}{l}\text { Spring, Lost Creek } \\
\text { Canyon, Las Vegas } \\
\text { Wash, Clark Co., NV }\end{array}$ & \\
\hline & P196 & $\begin{array}{l}\text { DQ363999 } \\
\text { (P196A), } \\
\text { DQ364000 } \\
(\text { P196D) }\end{array}$ & 2 & $0.00 \%$ & $\begin{array}{c}2.1 \% \text { with M16, } \\
\text { M17, M18 }\end{array}$ & $\begin{array}{l}\text { P. imperialis, } \\
\text { differ by } \\
3.9-4.2 \%\end{array}$ & $\begin{array}{l}\text { Grapevine Springs, } \\
\text { Amargosa River } \\
\text { basin, Nye Co., NV }\end{array}$ & \\
\hline \multirow[t]{7}{*}{$\begin{array}{l}\text { Pyrgulopsis } \\
\text { umbilicata }\end{array}$} & SM3 & EF1 19093-94 & 4 & $0-0.2 \%$ & $\begin{array}{c}0.3-0.5 \% \text { with } \\
\text { SM37 }\end{array}$ & $\begin{array}{l}\text { P. limaria, differ } \\
\text { by } 0.2-1.1 \%\end{array}$ & $\begin{array}{l}\text { Spring, northern } \\
\text { Soldier Meadow, } \\
\text { Humboldt Co., NV }\end{array}$ & \\
\hline & SMI 4 & EF119101 & 5 & $0.00 \%$ & $0.3 \%$ with SM37 & $\begin{array}{c}\text { P. limaria, differ } \\
\text { by } 0.2-0.9 \%\end{array}$ & $\begin{array}{l}\text { Spring, northern } \\
\text { Soldier Meadow, } \\
\text { Humboldt Co., NV }\end{array}$ & \\
\hline & SM16 & EF119102 & 5 & $0.00 \%$ & $0.3 \%$ with SM37 & $\begin{array}{l}\text { P. limaria, differ } \\
\text { by } 0.2-0.9 \%\end{array}$ & $\begin{array}{l}\text { Spring ca. } 40 \mathrm{~m} \\
\text { downflow from } \\
\text { source, northern } \\
\text { Soldier Meadow, } \\
\text { Humboldt Co., NV }\end{array}$ & \\
\hline & SM19 & EF119103 & 5 & $0.00 \%$ & $0.5 \%$ with SM37 & $\begin{array}{l}\text { P. limaria, differ } \\
\text { by } 0.3-1.1 \%\end{array}$ & $\begin{array}{l}\text { Spring, northern } \\
\text { Soldier Meadow, } \\
\text { Humboldt Co., NV }\end{array}$ & \\
\hline & SM20 & EF119104 & 4 & $0.00 \%$ & $0.3 \%$ with SM 37 & $\begin{array}{l}\text { P. limaria, differ } \\
\text { by } 0.2-0.9 \%\end{array}$ & $\begin{array}{l}\text { Spring, southern } \\
\text { Soldier Meadow, } \\
\text { Humboldt Co., NV }\end{array}$ & \\
\hline & SM21 & EF119105 & 4 & $0.00 \%$ & $0.3 \%$ with SM 37 & $\begin{array}{l}\text { P. limaria, differ } \\
\text { by } 0.2-0.9 \%\end{array}$ & $\begin{array}{l}\text { Spring } 5 \mathrm{~m} \\
\text { downflow from } \\
\text { SM20, southern } \\
\text { Soldier Meadow, } \\
\text { Humboldt Co., NV }\end{array}$ & \\
\hline & SM37 & EF119127 & 2 & $0.00 \%$ & $\begin{array}{c}0.3-0.5 \% \text { with } \\
\text { SM3, } 0.5 \% \text { with } \\
\text { SM19 }\end{array}$ & $\begin{array}{l}\text { P. limaria, differ } \\
\text { by } 0.5-1.2 \%\end{array}$ & $\begin{array}{l}\text { Spring, central } \\
\text { Soldier Meadow, } \\
\text { Humboldt Co., NV }\end{array}$ & \\
\hline $\begin{array}{l}\text { Pyrgulopsis } \\
\text { variegata }\end{array}$ & P106A & AY627937 & 1 & $0.00 \%$ & & $\begin{array}{l}\text { P. kolobensis, } \\
\text { differ by } \\
1.1-2.1 \% \text {, } \\
\text { P. sp. B, differ } \\
\text { by } 1.1 \%\end{array}$ & $\begin{array}{l}\text { Spring south of } \\
\text { South Patterson } \\
\text { Spring, Pilot Valley, } \\
\text { Box Elder Co., UT }\end{array}$ & \\
\hline
\end{tabular}




\begin{tabular}{|c|c|c|c|c|c|c|c|c|}
\hline Species & $\begin{array}{l}\text { Published } \\
\text { Sample } \\
\text { Codes }\end{array}$ & $\begin{array}{l}\text { Accession } \\
\text { Numbers }\end{array}$ & $\begin{array}{c}\text { No. of } \\
\text { Specimens (N) }\end{array}$ & $\begin{array}{l}\text { Sequence } \\
\text { Variation } \\
\text { (\% pairwise } \\
\text { distance) }\end{array}$ & $\begin{array}{c}\text { Most Distant } \\
\text { Conspecific } \\
\text { Sequences (\%) }\end{array}$ & $\begin{array}{c}\text { Closest } \\
\text { Interspecific } \\
\text { Sequences (\%) }\end{array}$ & Collection Locality & Comments \\
\hline \multirow[t]{6}{*}{$\begin{array}{l}\text { Pyrgulopsis } \\
\text { varneri }\end{array}$} & SM8 & EF119080 & 3 & $0.00 \%$ & $\begin{array}{c}0.0-0.3 \% \\
\text { with SM13, } \\
0.2 \% \\
\text { with SM15, } \\
\text { SM25, SM28 }\end{array}$ & $\begin{array}{l}\text { P. militaris, } \\
\text { differ by } \\
2.1-2.4 \%\end{array}$ & $\begin{array}{l}\text { Spring, southeast } \\
\text { Soldier Meadow, } \\
150 \text { m downflow } \\
\text { from source, } \\
\text { Humboldt Co., NV }\end{array}$ & \\
\hline & SM11 & EF119081 & 8 & $0.00 \%$ & $\begin{array}{c}0.0-0.3 \% \\
\text { with SM13, } \\
0.2 \% \text { with SM15, } \\
\text { SM } 25, \text { SM } 28\end{array}$ & $\begin{array}{l}\text { P. militaris, } \\
\text { differ by } \\
2.1-2.4 \%\end{array}$ & $\begin{array}{l}\text { Spring complex } \\
\text { (two springs), } \\
\text { southeast Soldier } \\
\text { Meadow, Humboldt } \\
\text { Co., NV }\end{array}$ & \\
\hline & SM13 & EF119082-84 & 4 & $0-0.5 \%$ & $\begin{array}{c}0.2-0.5 \% \\
\text { with SM15, } \\
\text { SM25, SM28 }\end{array}$ & $\begin{array}{l}\text { P. militaris, } \\
\text { differ by } \\
2.1-2.7 \%\end{array}$ & $\begin{array}{l}\text { Spring brook } \\
\text { downflow from } \\
\text { SM11, Humboldt } \\
\text { Co., NV }\end{array}$ & \\
\hline & SM15 & EF119085 & 5 & $0.00 \%$ & $\begin{array}{c}0.2-0.5 \% \\
\text { with SM13, } \\
0.3 \% \text { with } \\
\text { SM25, SM28 }\end{array}$ & $\begin{array}{l}\text { P. militaris, } \\
\text { differ by } \\
2.0-2.4 \%\end{array}$ & $\begin{array}{l}\text { Spring, northern } \\
\text { Soldier Meadow, } \\
\text { Humboldt Co., NV }\end{array}$ & \\
\hline & SM25 & EF119086 & 5 & $0.00 \%$ & $\begin{array}{l}0.2-0.5 \% \text { with } \\
\text { SM } 13,0.3 \% \\
\text { with SM15 }\end{array}$ & $\begin{array}{l}\text { P. militaris, } \\
\text { differ by } \\
2.3-2.6 \%\end{array}$ & $\begin{array}{l}\text { Satellite Spring } \\
\text { complex, spring "E," } \\
\text { Humboldt Co., NV }\end{array}$ & \\
\hline & SM28 & EF119087 & 4 & $0.00 \%$ & $\begin{array}{c}0.2-0.5 \% \\
\text { with SM13 } \\
0.3 \% \text { with SM } 15\end{array}$ & $\begin{array}{l}\text { P. militaris, } \\
\text { differ by } \\
2.3-2.6 \%\end{array}$ & $\begin{array}{l}\text { Satellite Spring } \\
\text { complex, spring "G," } \\
\text { Humboldt Co., NV }\end{array}$ & \\
\hline $\begin{array}{l}\text { Pyrgulopsis } \\
\text { ventricosa }\end{array}$ & P87 & AY426365-66 & 2 & $0.00 \%$ & & $\begin{array}{l}\text { P. kolobensis, } \\
\text { differ by } \\
4.5-5.5 \% \\
\text { P. marcida, } \\
\text { differ by } 4.5 \% \text {, } \\
\text { P. plicata, } \\
\text { differ by } 4.5 \%\end{array}$ & $\begin{array}{l}\text { Spring, Seigler } \\
\text { Canyon, Clear Lake } \\
\text { Basin, Lake Co., CA }\end{array}$ & \\
\hline $\begin{array}{l}\text { Pyrgulopsis } \\
\text { villacampae }\end{array}$ & P83A & AY627933 & 1 & $0.00 \%$ & & $\begin{array}{l}\text { P. lockensis, } \\
\text { differ by } 2.6 \%\end{array}$ & $\begin{array}{l}\text { Little Warm Spring, } \\
\text { Railroad Valley, Nye } \\
\text { Co., NV }\end{array}$ & \\
\hline $\begin{array}{l}\text { Pyrgulopsis } \\
\text { vinyardi }\end{array}$ & SM38A & EU700482 & 1 & $0.00 \%$ & & $\begin{array}{l}\text { P. gibba, differ } \\
\text { by } 0.5-1.1 \% \text {, } \\
\text { P. plicata, differ } \\
\text { by } 4.6 \%\end{array}$ & $\begin{array}{l}\text { Unnamed spring, } \\
\text { Squaw Valley, Elko } \\
\text { Co., NV }\end{array}$ & \\
\hline \multirow[t]{2}{*}{$\begin{array}{l}\text { Pyrgulopsis } \\
\text { wongi }\end{array}$} & & AF520923 & 1 & $0.00 \%$ & $\begin{array}{c}7.1 \% \\
\text { with W3 }\end{array}$ & $\begin{array}{c}\text { P. kolobensis, } \\
\text { differ by } \\
3.4-4.6 \% \text {, } \\
\text { P. marcida, } \\
\text { differ by } 3.8 \% \text {, } \\
\text { P. nonaria, } \\
\text { differ by } 3.9 \% \text {, } \\
\text { P. pilsbryana, } \\
\text { differ by } \\
3.8-3.9 \% \text {, } \\
\text { P. transversa, } \\
\text { differ by } 3.8 \% \text {, } \\
\text { P. sp. D, differ } \\
\text { by } 3.8 \% \\
\text { P. sp. H, differ } \\
\text { by } 3.9 \%\end{array}$ & $\begin{array}{l}\text { Spring, lower Pine } \\
\text { Creek Canyon, Inyo } \\
\text { Co., CA }\end{array}$ & \\
\hline & P185 & $\begin{array}{l}\text { AY627956 } \\
\text { (P185A, } \\
\text { P185C) }\end{array}$ & 4 & $0.00 \%$ & $\begin{array}{c}6.7 \% \\
\text { with W3 }\end{array}$ & $\begin{array}{l}\text { P. kolobensis, } \\
\text { differ by } \\
3.3-4.5 \% \\
\text { P. marcida, } \\
\text { differ by } 3.7 \%\end{array}$ & $\begin{array}{l}\text { Spring, Birchim } \\
\text { Canyon, Inyo Co., } \\
\text { CA }\end{array}$ & \\
\hline
\end{tabular}




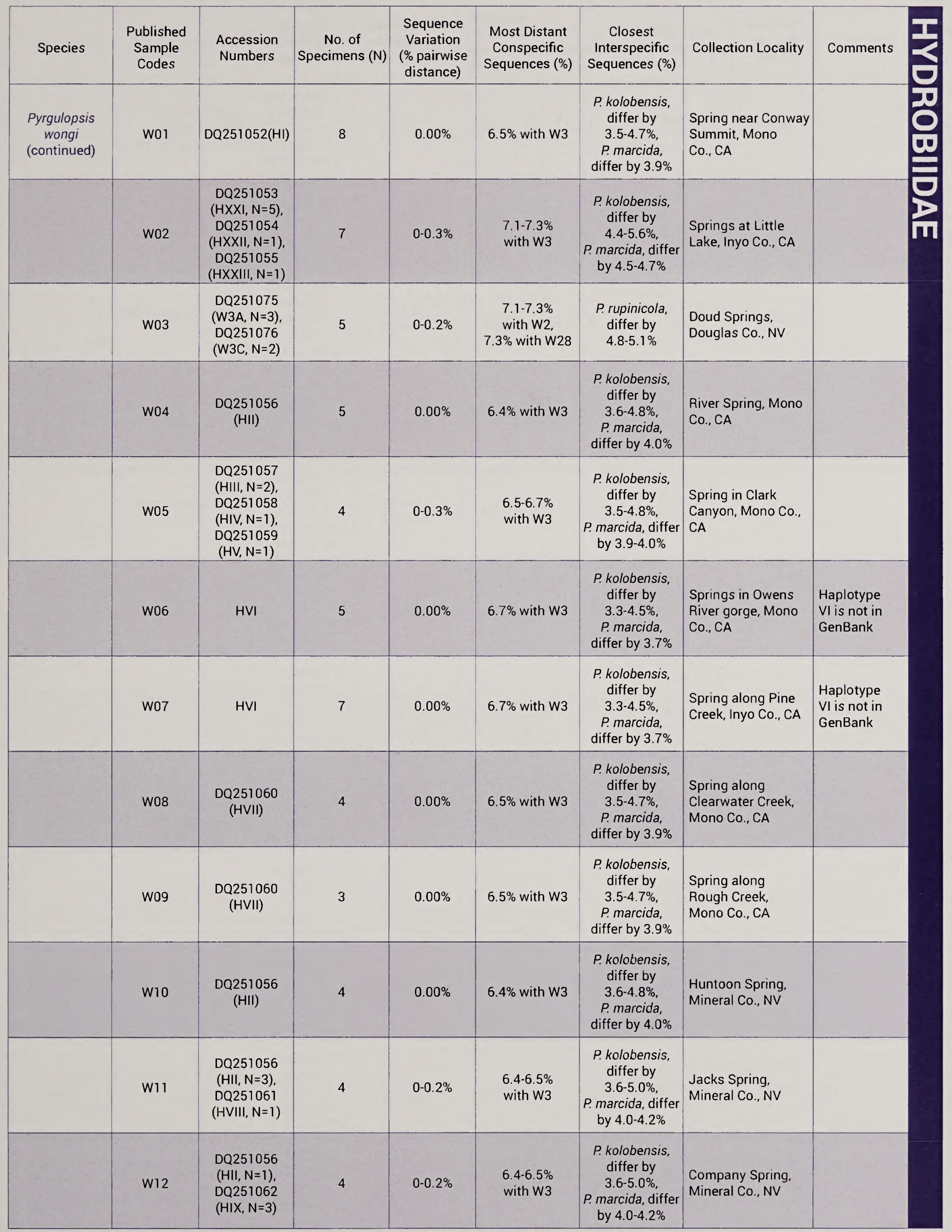




\begin{tabular}{|c|c|c|c|c|c|c|c|c|}
\hline Species & $\begin{array}{l}\text { Published } \\
\text { Sample } \\
\text { Codes }\end{array}$ & $\begin{array}{l}\text { Accession } \\
\text { Numbers }\end{array}$ & $\begin{array}{c}\text { No. of } \\
\text { Specimens (N) }\end{array}$ & $\begin{array}{l}\text { Sequence } \\
\text { Variation } \\
\text { (\% pairwise } \\
\text { distance) }\end{array}$ & $\begin{array}{l}\text { Most Distant } \\
\text { Conspecific } \\
\text { Sequences (\%) }\end{array}$ & $\begin{array}{c}\text { Closest } \\
\text { Interspecific } \\
\text { Sequences (\%) }\end{array}$ & Collection Locality & Comments \\
\hline \multirow[t]{12}{*}{$\begin{array}{l}\text { Pyrgulopsis } \\
\text { wongi } \\
\text { (continued) }\end{array}$} & W13 & $\begin{array}{l}\text { DQ251063 } \\
(H X)\end{array}$ & 4 & $0.00 \%$ & $\begin{array}{c}6.5 \% \\
\text { with W3 }\end{array}$ & $\begin{array}{c}\text { P. kolobensis, } \\
\text { differ by } \\
3.5-4.7 \% \text {, } \\
\text { P. marcida, } \\
\text { differ by } 3.9 \%\end{array}$ & $\begin{array}{l}\text { Spring east of } \\
\text { McNett Ranch, } \\
\text { Esmeralda Co., NV }\end{array}$ & \\
\hline & W14 & $\begin{array}{l}\text { DQ251064 } \\
(H X I)\end{array}$ & 4 & $0.00 \%$ & $\begin{array}{c}6.4 \% \\
\text { with W3 }\end{array}$ & $\begin{array}{c}\text { P. kolobensis, } \\
\text { differ by } \\
3.3-4.4 \% \text {, } \\
\text { P. marcida, } \\
\text { differ by } 3.7 \%\end{array}$ & $\begin{array}{l}\text { Cave Spring, } \\
\text { Esmeralda Co., NV }\end{array}$ & \\
\hline & W15 & $\begin{array}{l}\text { DQ251064 } \\
\quad(H X I)\end{array}$ & 8 & $0.00 \%$ & $\begin{array}{c}6.4 \% \\
\text { with W3 }\end{array}$ & $\begin{array}{c}\text { P. kolobensis, } \\
\text { differ by } \\
3.3-4.4 \% \text {, } \\
\text { P. marcida, } \\
\text { differ by } 3.7 \%\end{array}$ & $\begin{array}{l}\text { Corral Springs, Inyo } \\
\text { Co., CA }\end{array}$ & \\
\hline & W16 & $\begin{array}{l}\text { DQ251065 } \\
\quad(H X I I)\end{array}$ & 6 & $0.00 \%$ & $\begin{array}{c}6.5 \% \\
\text { with W3 }\end{array}$ & $\begin{array}{c}\text { P. kolobensis, } \\
\text { differ by } \\
3.5-4.5 \% \text {, } \\
\text { P. marcida, } \\
\text { differ by } 3.9 \%\end{array}$ & $\begin{array}{l}\text { Antelope Springs, } \\
\text { Inyo Co., CA }\end{array}$ & \\
\hline & W17 & $\begin{array}{l}\text { DQ251056 } \\
(H I I, N=5), \\
\text { DQ251063 } \\
(H X, N=1)\end{array}$ & 6 & $0-0.5 \%$ & $\begin{array}{l}6.4-6.5 \% \\
\text { with W3 }\end{array}$ & $\begin{array}{l}\text { P. kolobensis, } \\
\text { differ by } \\
3.5-4.8 \% \\
\text { P. marcida, differ } \\
\text { by } 3.9-4.0 \%\end{array}$ & $\begin{array}{l}\text { Springs at Pizona, } \\
\text { Mono Co., CA }\end{array}$ & \\
\hline & W18 & $\begin{array}{c}\text { DQ251066 } \\
(H X I I I, N=3) \\
\text { DQ251067 } \\
(H X I V, N=1)\end{array}$ & 4 & $0-0.2 \%$ & $\begin{array}{c}6.5 \% \\
\text { with W3 }\end{array}$ & $\begin{array}{l}\text { P. kolobensis, } \\
\text { differ by } \\
3.5-4.8 \% \text {, } \\
\text { P. marcida, differ } \\
\text { by } 3.9-4.0 \%\end{array}$ & $\begin{array}{l}\text { Layton Springs, } \\
\text { Mono Co., CA }\end{array}$ & \\
\hline & W19 & $\begin{array}{c}\text { DQ251060 } \\
(H V I I, N=2), \\
\text { DQ251068 } \\
(H X V, N=1), \\
\text { DQ251069 } \\
(H X V 1, N=1)\end{array}$ & 4 & $0-0.3 \%$ & $\begin{array}{l}6.5-6.7 \% \\
\text { with W3 }\end{array}$ & $\begin{array}{l}\text { P. kolobensis, } \\
\text { differ by } \\
3.5-4.8 \% \text {, } \\
\text { P. marcida, differ } \\
\text { by } 3.9-4.0 \%\end{array}$ & $\begin{array}{l}\text { Springs along } \\
\text { northeast side of } \\
\text { Blind Spring Hill, } \\
\text { Mono Co., CA }\end{array}$ & \\
\hline & W20 & $\begin{array}{l}\text { DQ251060 } \\
\quad(H V I I)\end{array}$ & 6 & $0.00 \%$ & $\begin{array}{c}6.5 \% \\
\text { with W3 }\end{array}$ & $\begin{array}{c}\text { P. kolobensis, } \\
\text { differ by } \\
3.5-4.7 \% \text {, } \\
\text { P. marcida, } \\
\text { differ by } 3.9 \%\end{array}$ & $\begin{array}{l}\text { Spring in West } \\
\text { Queen Canyon, } \\
\text { Mineral Co., NV }\end{array}$ & \\
\hline & W21 & $\begin{array}{l}\text { DQ251070 } \\
\text { (HXVII) }\end{array}$ & 6 & $0.00 \%$ & $\begin{array}{c}6.4 \% \\
\text { with W3 }\end{array}$ & $\begin{array}{c}\text { P. kolobensis, } \\
\text { differ by } \\
3.3-4.4 \% \\
\text { P. marcida, } \\
\text { differ by } 3.7 \%\end{array}$ & $\begin{array}{l}\text { Spring south of } \\
\text { Warren Lake, Inyo } \\
\text { Co., CA }\end{array}$ & \\
\hline & W22 & $\begin{array}{c}\text { DQ251071 } \\
(H X V I I I, N=5), \\
\text { DQ251072 } \\
(H X I X, N=1)\end{array}$ & 6 & $0-0.2 \%$ & $\begin{array}{l}6.5-6.7 \% \\
\text { with W3 }\end{array}$ & $\begin{array}{c}\text { P. kolobensis, } \\
\text { differ by } \\
3.2-4.7 \% \\
\text { P. marcida, differ } \\
\text { by } 3.6-3.7 \%\end{array}$ & $\begin{array}{l}\text { Spring along } \\
\text { Lubken Creek, } \\
\text { Inyo Co., CA }\end{array}$ & \\
\hline & W23 & $\mathrm{HVI}$ & 4 & $0.00 \%$ & $\begin{array}{c}6.7 \% \\
\text { with W3 }\end{array}$ & $\begin{array}{l}\text { P. kolobensis, } \\
\text { differ by } \\
3.3-4.5 \% \\
\text { P. marcida, } \\
\text { differ by } 3.7 \%\end{array}$ & $\begin{array}{l}\text { Spring in Marble } \\
\text { Canyon, Inyo Co., } \\
\text { CA }\end{array}$ & $\begin{array}{l}\text { Haplotype } \\
\text { VI is not in } \\
\text { GenBank }\end{array}$ \\
\hline & W24 & $\begin{array}{l}\text { DQ251053 } \\
\text { (HXXI) }\end{array}$ & 5 & $0.00 \%$ & $\begin{array}{c}7.1 \% \\
\text { with W3 }\end{array}$ & $\begin{array}{l}\text { P. kolobensis, } \\
\text { differ by } \\
4.4-5.5 \% \\
\text { P. marcida, } \\
\text { differ by } 4.5 \%\end{array}$ & $\begin{array}{l}\text { Spring south of } \\
\text { Summit Creek, Inyo } \\
\text { Co., CA }\end{array}$ & \\
\hline
\end{tabular}




\begin{tabular}{|c|c|c|c|c|c|c|c|c|}
\hline Species & $\begin{array}{l}\text { Published } \\
\text { Sample } \\
\text { Codes }\end{array}$ & $\begin{array}{l}\text { Accession } \\
\text { Numbers }\end{array}$ & $\begin{array}{c}\text { No. of } \\
\text { Specimens }(\mathrm{N})\end{array}$ & $\begin{array}{l}\text { Sequence } \\
\text { Variation } \\
\text { (\% pairwise } \\
\text { distance) }\end{array}$ & $\begin{array}{l}\text { Most Distant } \\
\text { Conspecific } \\
\text { Sequences (\%) }\end{array}$ & $\begin{array}{c}\text { Closest } \\
\text { Interspecific } \\
\text { Sequences (\%) }\end{array}$ & Collection Locality & Comments \\
\hline \multirow[t]{4}{*}{$\begin{array}{c}\text { Pyrgulopsis } \\
\text { wongi } \\
\text { (continued) }\end{array}$} & W25 & $\begin{array}{l}\text { DQ251064 } \\
\quad(H X I)\end{array}$ & 5 & $0.00 \%$ & $6.4 \%$ with W3 & $\begin{array}{c}\text { P. kolobensis, } \\
\text { differ by } \\
3.3-4.4 \% \text {, } \\
\text { P. marcida, } \\
\text { differ by } 3.7 \%\end{array}$ & $\begin{array}{l}\text { Boron Springs, Inyo } \\
\text { Co., CA }\end{array}$ & \\
\hline & W26 & $\begin{array}{l}\text { DQ251064 } \\
(H X I, N=3), \\
\text { DQ251073 } \\
(H X X, N=2)\end{array}$ & 5 & $0-0.2 \%$ & $\begin{array}{l}6.2-6.4 \% \\
\text { with W3 }\end{array}$ & $\begin{array}{l}\text { P. kolobensis, } \\
\text { differ by } \\
3.2-4.4 \% \text {, } \\
\text { P. marcida, differ } \\
\text { by } 3.6-3.7 \%\end{array}$ & $\begin{array}{l}\text { French Spring, Inyo } \\
\text { Co., CA }\end{array}$ & \\
\hline & W27 & $\begin{array}{l}\text { DQ251064 } \\
\quad(H X I)\end{array}$ & 5 & $0.00 \%$ & $6.4 \%$ with W3 & $\begin{array}{c}\text { P. kolobensis, } \\
\text { differ by } \\
3.3-4.4 \% \text {, } \\
\text { P. marcida, } \\
\text { differ by } 3.7 \%\end{array}$ & $\begin{array}{l}\text { Barrel Springs, Inyo } \\
\text { Co., CA }\end{array}$ & \\
\hline & W28 & $\begin{array}{l}\text { DQ251074 } \\
\text { (HXXIV) }\end{array}$ & 5 & $0.00 \%$ & $7.3 \%$ with W3 & $\begin{array}{l}\text { P. kolobensis, } \\
\text { differ by } \\
4.6-5.6 \% \text {, } \\
\text { P. marcida, } \\
\text { differ by } 4.7 \%\end{array}$ & $\begin{array}{l}\text { Spring north of } \\
\text { Johnson Canyon, } \\
\text { Inyo Co., CA }\end{array}$ & \\
\hline \multirow[t]{3}{*}{$\begin{array}{l}\text { Pyrgulopsis } \\
\text { sp. A }\end{array}$} & $\mathrm{BS} / \mathrm{D} 23 \mathrm{~A}$ & $\begin{array}{c}\text { AY197587 } \\
\text { (BS/D23A), } \\
\text { AY426367 } \\
\text { (D23C) }\end{array}$ & 2 & $1.20 \%$ & $\begin{array}{c}1.0-1.2 \% \text { with } \\
\text { KL_b }\end{array}$ & $\begin{array}{l}\text { P. archimedis, } \\
\text { differ by } \\
2.6-3.6 \% \text {, } \\
\text { P. rupinicola, } \\
\text { differ by } \\
2.4-3.4 \%\end{array}$ & $\begin{array}{l}\text { Big Springs at } \\
\text { Bonanza, Klamath } \\
\text { basin, Klamath } \\
\text { Co., OR }\end{array}$ & $\begin{array}{l}\text { AY197587/ } \\
\text { BS/D23A } \\
\text { listed as } P \text {. } \\
\text { sp. HPL-2003 } \\
\text { isolate BS } \\
\text { in GenBank, } \\
\text { AY426367/ } \\
\text { D23C listed } \\
\text { as } P \text {. sp. } \\
\text { USNM } \\
1016099 \\
\text { isolate D23C } \\
\text { in GenBank }\end{array}$ \\
\hline & KL_b & AY197588 & 1 & $0.00 \%$ & $\begin{array}{c}1.0-1.2 \% \text { with } \\
\text { BS/D23 }\end{array}$ & $\begin{array}{l}\text { P. archimedis, } \\
\text { differ by } \\
2.7-3.2 \% \text {, } \\
\text { P. rupinicola, } \\
\text { differ by } \\
3.1-3.2 \%\end{array}$ & $\begin{array}{l}\text { Seventh Link River } \\
\text { spring, Klamath } \\
\text { basin, Klamath } \\
\text { Co., OR }\end{array}$ & $\begin{array}{l}\text { AY197588KLb } \\
\text { listed as } P \text {. } \\
\text { sp. HPL-2003 } \\
\text { isolate KLb in } \\
\text { GenBank }\end{array}$ \\
\hline & SP/D25 & $\begin{array}{l}\text { AY197589 } \\
\text { (SP/D25A), } \\
\text { AY426368 } \\
\text { (D25B) }\end{array}$ & 2 & $0.00 \%$ & $\begin{array}{c}0.5-0.7 \% \text { with } \\
\text { D23, 0.5\% with } \\
\text { KL_b }\end{array}$ & $\begin{array}{l}\text { P. archimedis, } \\
\text { differ by } \\
2.4-3.0 \% \text {, } \\
\text { P. rupinicola, } \\
\text { differ by } \\
2.6-2.8 \%\end{array}$ & $\begin{array}{l}\text { Sprague River north } \\
\text { of Beatty, Klamath } \\
\text { basin, Lake Co., OR }\end{array}$ & $\begin{array}{l}\text { AY197589/ } \\
\text { SP/D25A } \\
\text { listed as P. } \\
\text { sp. HPL-2003 } \\
\text { isolate SP } \\
\text { in GenBank, } \\
\text { AY426368/ } \\
\text { D25B listed } \\
\text { as } P \text {. Sp. } \\
\text { USNM } \\
1016100 \\
\text { isolate D25B } \\
\text { in GenBank }\end{array}$ \\
\hline $\begin{array}{l}\text { Pyrgulopsis } \\
\text { sp. B }\end{array}$ & P161 & AY379446-47 & 2 & $0.00 \%$ & & $\begin{array}{l}\text { P. variegata, } \\
\text { differ by } 1.1 \% \text {, } \\
\text { P. sp. I, differ } \\
\text { by } 0.2 \%\end{array}$ & $\begin{array}{l}\text { Teton River, Buxton } \\
\text { Bridge crossing, } \\
\text { Teton Co., WY }\end{array}$ & $\begin{array}{l}\text { P. sp. } \\
\text { B-HPL-2003 } \\
\text { isolate } \\
\text { P161A/ } \\
\text { P161B in } \\
\text { GenBank }\end{array}$ \\
\hline
\end{tabular}




\begin{tabular}{|c|c|c|c|c|c|c|c|c|}
\hline Species & $\begin{array}{l}\text { Published } \\
\text { Sample } \\
\text { Codes }\end{array}$ & $\begin{array}{l}\text { Accession } \\
\text { Numbers }\end{array}$ & $\begin{array}{c}\text { No. of } \\
\text { Specimens }(\mathrm{N})\end{array}$ & $\begin{array}{l}\text { Sequence } \\
\text { Variation } \\
\text { (\% pairwise } \\
\text { distance) }\end{array}$ & $\begin{array}{l}\text { Most Distant } \\
\text { Conspecific } \\
\text { Sequences (\%) }\end{array}$ & $\begin{array}{c}\text { Closest } \\
\text { Interspecific } \\
\text { Sequences (\%) }\end{array}$ & Collection Locality & Comments \\
\hline $\begin{array}{l}\text { Pyrgulopsis } \\
\text { sp. C }\end{array}$ & P139 & $\begin{array}{c}\text { EU700472 } \\
(\text { P139A), } \\
\text { AY426369 } \\
\text { (P139B), } \\
\text { AY426970 } \\
\text { (P139C) }\end{array}$ & 3 & $0.00 \%$ & & $\begin{array}{c}\text { P. kolobensis, } \\
\text { differ by } \\
0.2-3.0 \% \text {, } \\
\text { P. pilsbryana, } \\
\text { differ by } \\
0-0.2 \% \text {, } \\
\text { P. transversa, } \\
\text { differ by } 1.1 \% \text {, } \\
\text { P. sp. D, } \\
\text { differ by } 0.2 \% \text {, } \\
\text { P. sp. H, } \\
\text { differ by } 0 \%\end{array}$ & $\begin{array}{l}\text { Mud Creek, Birch } \\
\text { Creek Valley, Lemhi } \\
\text { Co., ID }\end{array}$ & $\begin{array}{l}\text { P. sp. Birch } \\
\text { Creek isolate } \\
\text { P139A in } \\
\text { GenBank, } \\
\text { P. sp. } \\
\text { USNM905287 } \\
\text { isolate P139B } \\
\text { in GenBank, } \\
\text { P. sp. } \\
\text { USNM905287 } \\
\text { isolate P139C } \\
\text { in GenBank, } \\
\text { P. pilsbryana } \\
\text { clade in } \\
\text { Hershler et al. } \\
\text { (2008) } \\
\end{array}$ \\
\hline $\begin{array}{l}\text { Pyrgulopsis } \\
\text { sp. E }\end{array}$ & P78B & EU700465 & 1 & $0.00 \%$ & & $\begin{array}{l}\text { P. kolobensis, } \\
\text { differ by } \\
7.5-9.6 \% \text {, } \\
\text { P. pilsbryana, } \\
\text { differ by } \\
7.6-8.0 \% \\
\text { P. sp. H, } \\
\text { differ by } 7.7 \%\end{array}$ & $\begin{array}{l}\text { Indian Springs, } \\
\text { Cold Creek drainage, } \\
\text { Power Co., ID }\end{array}$ & $\begin{array}{l}\text { P. sp. Indian } \\
\text { Springs } \\
\text { isolate P78B } \\
\text { in GenBank }\end{array}$ \\
\hline $\begin{array}{l}\text { Pyrgulopsis } \\
\text { sp. G }\end{array}$ & P160A & EU700476 & 1 & $0.00 \%$ & & $\begin{array}{c}\text { P. kolobensis, } \\
\text { differ by } \\
3.3-4.6 \% \text {, } \\
\text { P. marcida, } \\
\text { differ by } 3.8 \% \text {, } \\
\text { P. nonaria, } \\
\text { differ by } 3.7 \% \text {, } \\
\text { P. variegata, } \\
\text { differ by } 3.8 \%\end{array}$ & $\begin{array}{l}\text { Upper Rock Spring, } \\
\text { Bannock Creek } \\
\text { drainage, Power } \\
\text { Co., ID }\end{array}$ & $\begin{array}{l}\text { P. sp. Upper } \\
\text { Rock Spring } \\
\text { isolate P160A } \\
\text { in GenBank }\end{array}$ \\
\hline
\end{tabular}




\begin{tabular}{|c|c|c|c|c|c|c|c|c|}
\hline Species & $\begin{array}{l}\text { Published } \\
\text { Sample } \\
\text { Codes }\end{array}$ & $\begin{array}{l}\text { Accession } \\
\text { Numbers }\end{array}$ & $\begin{array}{c}\text { No. of } \\
\text { Specimens (N) }\end{array}$ & $\begin{array}{l}\text { Sequence } \\
\text { Variation } \\
\text { (\% pairwise } \\
\text { distance) }\end{array}$ & $\begin{array}{l}\text { Most Distant } \\
\text { Conspecific } \\
\text { Sequences (\%) }\end{array}$ & $\begin{array}{c}\text { Closest } \\
\text { Interspecific } \\
\text { Sequences (\%) }\end{array}$ & Collection Locality & Comments \\
\hline $\begin{array}{l}\text { Pyrgulopsis } \\
\text { sp. H }\end{array}$ & P163A & EU700477 & 1 & $0.00 \%$ & & $\begin{array}{c}\text { P. kolobensis, } \\
\text { differ by } \\
0.2-2.7 \% \text {, } \\
\text { P. nonaria, } \\
\text { differ by } 1.2 \% \text {, } \\
\text { P. pilsbryana, } \\
\text { differ by } 0-0.2 \% \text {, } \\
\text { P. transversa, } \\
\text { differ by } 1.1 \% \text {, } \\
\text { P. sp. C, differ } \\
\text { by } 0.0 \% \text {, } \\
\text { P. sp. D, differ } \\
\text { by } 0.2 \%\end{array}$ & $\begin{array}{l}\text { Kaufman Cabin } \\
\text { Springs, Birch Creek } \\
\text { Valley, Lemhi Co., ID }\end{array}$ & $\begin{array}{l}P . \text { sp. } \\
\text { Kaufman } \\
\text { Cabin isolate } \\
\text { P163A in } \\
\text { Genbank, } \\
\text { P. pilsbryana } \\
\text { clade in } \\
\text { Hershler et al. } \\
(2008)\end{array}$ \\
\hline $\begin{array}{l}\text { Pyrgulopsis } \\
\text { sp. I }\end{array}$ & P214A & EU700481 & 1 & $0.00 \%$ & & $\begin{array}{l}\text { P. variegata, } \\
\text { differ by } 1.3 \% \text {, } \\
\text { P. sp. B, differ } \\
\text { by } 0.2 \%\end{array}$ & $\begin{array}{l}\text { Spring, at Porcupine } \\
\text { Ranger Station, } \\
\text { Henrys Fork } \\
\text { drainage, Fremont } \\
\text { Co., ID }\end{array}$ & $\begin{array}{l}\text { P. sp. } \\
\text { Porcupine } \\
\text { isolate P214A } \\
\text { in GenBank }\end{array}$ \\
\hline \multicolumn{9}{|c|}{ Fluminicola } \\
\hline \multirow[t]{12}{*}{$\begin{array}{l}\text { Fluminicola } \\
\text { ahjumawi }\end{array}$} & sem93C & AY962894 & 1 & $0 \%$ & $\begin{array}{l}0.9 \% \text { with } \\
\text { SP476B }\end{array}$ & $\begin{array}{l}\text { F. lunsfordensis, } \\
\text { differ by } 2.2 \%\end{array}$ & $\begin{array}{l}\text { Lost Creek (middle } \\
\text { site), Shasta Co., CA }\end{array}$ & \\
\hline & F10_116B & AY962895 & 1 & $0 \%$ & $\begin{array}{l}1.1 \% \text { with } \\
\text { SP476B }\end{array}$ & $\begin{array}{l}\text { F. lunsfordensis, } \\
\text { differ by } 2.0 \%\end{array}$ & $\begin{array}{l}\text { Hat Creek at Bridge } \\
\text { Picnic Area, Shasta } \\
\text { Co., CA }\end{array}$ & \\
\hline & F10_164A & AY962896 & 1 & $0 \%$ & $\begin{array}{l}1.1 \% \text { with } \\
\text { SP476B }\end{array}$ & $\begin{array}{l}\text { F. lunsfordensis, } \\
\text { differ by } 2.0 \%\end{array}$ & $\begin{array}{l}\text { Three springs on } \\
\text { point opposite large } \\
\text { island in Pit River, } \\
\text { Shasta Co., CA }\end{array}$ & \\
\hline & F10_195C & AY962897 & 1 & $0 \%$ & $\begin{array}{l}1.1 \% \text { with } \\
\text { SP476B }\end{array}$ & $\begin{array}{c}\text { F. lunsfordensis, } \\
\text { differ by } 1.9 \%\end{array}$ & $\begin{array}{l}\text { Spring run near } \\
\text { Pit River hatchery, } \\
\text { Shasta Co., CA }\end{array}$ & \\
\hline & $\operatorname{sem} 340 A$ & AY962898 & 1 & $0 \%$ & $\begin{array}{l}1.2 \% \text { with } \\
\text { SP476B }\end{array}$ & $\begin{array}{l}\text { F. lunsfordensis, } \\
\text { differ by } 1.9 \%\end{array}$ & $\begin{array}{l}\text { Honn Creek, Shasta } \\
\text { Co., CA }\end{array}$ & \\
\hline & F10_344B & AY962899 & 1 & $0 \%$ & $\begin{array}{c}0.9 \% \text { with } \\
\text { SP } 476 \mathrm{~B}, 0.9 \% \\
\text { with Fsem535A }\end{array}$ & $\begin{array}{l}\text { F. lunsfordensis, } \\
\text { differ by } 1.9 \%\end{array}$ & $\begin{array}{l}\text { Spring run north of } \\
\text { Sam Wolfin Spring, } \\
\text { Shasta Co., CA }\end{array}$ & \\
\hline & FSP345E & AY 962900 & 1 & $0 \%$ & $\begin{array}{l}1.1 \% \text { with } \\
\text { SP476B }\end{array}$ & $\begin{array}{l}\text { F. lunsfordensis, } \\
\text { differ by } 1.9 \%\end{array}$ & $\begin{array}{l}\text { Upper Sucker } \\
\text { Springs Creek, } \\
\text { Shasta Co., CA }\end{array}$ & \\
\hline & $\operatorname{sem} 347 B$ & AY962901 & 1 & $0 \%$ & $\begin{array}{l}1.1 \% \text { with } \\
\text { SP476B }\end{array}$ & $\begin{array}{l}\text { F. lunsfordensis, } \\
\text { differ by } 2.0 \%\end{array}$ & $\begin{array}{l}\text { Spring west of } \\
\text { Thousand Spring } \\
\text { run, Shasta Co., CA }\end{array}$ & \\
\hline & $\operatorname{sem} 349 A$ & AY962902 & 1 & $0 \%$ & $\begin{array}{l}1.1 \% \text { with } \\
\text { SP476B }\end{array}$ & $\begin{array}{l}\text { F. lunsfordensis, } \\
\text { differ by } 2.0 \%\end{array}$ & $\begin{array}{l}\text { West spring source } \\
\text { of Mallard Creek, } \\
\text { Shasta Co., CA }\end{array}$ & \\
\hline & F10_405A & AY962903 & 1 & $0 \%$ & $\begin{array}{c}0.9 \% \text { with } \\
\text { SP } 476 \mathrm{~B}, 0.9 \% \\
\text { with Fsem } 535 \mathrm{~A}\end{array}$ & $\begin{array}{l}\text { F. lunsfordensis, } \\
\text { differ by } 1.9 \%\end{array}$ & $\begin{array}{l}\text { Beaver Creek, } \\
\text { Lassen Co., CA }\end{array}$ & \\
\hline & sem $408 C$ & AY962904 & 1 & $0 \%$ & $\begin{array}{l}0.9 \% \text { with } \\
\text { SP476B }\end{array}$ & $\begin{array}{l}\text { F. lunsfordensis, } \\
\text { differ by } 2.5 \%\end{array}$ & $\begin{array}{l}\text { Burney Creek, } \\
\text { upstream of } \\
\text { Burney Falls, } \\
\text { Shasta Co., CA }\end{array}$ & \\
\hline & SP476B & AY962905 & 1 & $0 \%$ & $\begin{array}{l}1.2 \% \text { with } \\
\text { sem } 340 A\end{array}$ & $\begin{array}{l}\text { F. lunsfordensis, } \\
\text { differ by } 2.7 \%\end{array}$ & $\begin{array}{l}\text { Jimmerson Spring, } \\
\text { Modoc Co., CA }\end{array}$ & \\
\hline
\end{tabular}




\begin{tabular}{|c|c|c|c|c|c|c|c|c|}
\hline Species & $\begin{array}{l}\text { Published } \\
\text { Sample } \\
\text { Codes }\end{array}$ & $\begin{array}{l}\text { Accession } \\
\text { Numbers }\end{array}$ & $\begin{array}{c}\text { No. of } \\
\text { Specimens }(\mathrm{N})\end{array}$ & $\begin{array}{l}\text { Sequence } \\
\text { Variation } \\
\text { (\% pairwise } \\
\text { distance) }\end{array}$ & $\begin{array}{l}\text { Most Distant } \\
\text { Conspecific } \\
\text { Sequences (\%) }\end{array}$ & $\begin{array}{c}\text { Closest } \\
\text { Interspecific } \\
\text { Sequences (\%) }\end{array}$ & Collection Locality & Comments \\
\hline \multirow[t]{2}{*}{$\begin{array}{l}\text { Fluminicola } \\
\text { ahjumawi } \\
\text { (continued) }\end{array}$} & Fsem $535 \mathrm{~A}$ & AY962906 & 1 & $0 \%$ & $\begin{array}{c}0.9 \% \text { with } \\
\text { F10_195C, } \\
\text { sem340A, } \\
\text { F10_344B, } \\
\text { F10_405A, } \\
\text { SP476B }\end{array}$ & $\begin{array}{l}\text { F. lunsfordensis, } \\
\text { differ by } 2.7 \%\end{array}$ & $\begin{array}{l}\text { Lost Creek near } \\
\text { source spring, } \\
\text { Shasta Co., CA }\end{array}$ & \\
\hline & Fsem536A & AY962907 & 1 & $0 \%$ & $\begin{array}{c}0.8 \% \text { with } \\
\text { F10_195C, } \\
\text { sem340A, } \\
\text { F10_344B, } \\
\text { F10_405A, } \\
\text { SP476B }\end{array}$ & $\begin{array}{l}\text { F. lunsfordensis, } \\
\text { differ by } 2.5 \%\end{array}$ & $\begin{array}{l}\text { Lost Creek } \\
\text { (uppermost site), } \\
\text { Shasta Co., CA }\end{array}$ & \\
\hline \multirow[t]{4}{*}{$\begin{array}{l}\text { Fluminicola } \\
\text { anserinus }\end{array}$} & F6_40B & AY962984 & 1 & $0 \%$ & $\begin{array}{c}2.7 \% \text { with } \\
\text { F15_270B, } \\
\text { SP395A }\end{array}$ & $\begin{array}{l}\text { F. multifarius, } \\
\text { differ by } \\
2.9-3.8 \%\end{array}$ & $\begin{array}{l}\text { Spring near Chalk } \\
\text { Mountain, Shasta } \\
\text { Co., CA }\end{array}$ & \\
\hline & F15_270B & AY962908 & 1 & $0 \%$ & $\begin{array}{c}2.7 \% \text { with } \\
\text { F6_40B }\end{array}$ & $\begin{array}{l}\text { F. multifarius, } \\
\text { differ by } \\
2.7-3.6 \%\end{array}$ & $\begin{array}{l}\text { Spring, Goose } \\
\text { Valley, Shasta Co., } \\
\text { CA }\end{array}$ & \\
\hline & F6_321A & AY962985 & 1 & $0 \%$ & $\begin{array}{l}2.4 \% \text { with } \\
\text { F15_270B, } \\
\text { SP395A }\end{array}$ & $\begin{array}{l}\text { F. multifarius, } \\
\text { differ by } \\
2.6-3.5 \%\end{array}$ & $\begin{array}{l}\text { Blackberry Creek, } \\
\text { Shasta Co.. CA }\end{array}$ & \\
\hline & SP395A & AY962909 & 1 & $0 \%$ & $\begin{array}{c}2.7 \% \text { with } \\
\text { F6_40B }\end{array}$ & $\begin{array}{l}\text { F. multifarius, } \\
\text { differ by } \\
2.7-3.6 \%\end{array}$ & $\begin{array}{l}\text { Rim of the Lake } \\
\text { Spring, Shasta } \\
\text { Co., CA }\end{array}$ & \\
\hline \multirow[t]{5}{*}{$\begin{array}{l}\text { Fluminicola } \\
\text { caballensis }\end{array}$} & SP400A & AY962910 & 1 & $0 \%$ & $\begin{array}{l}0.8 \% \text { with } \\
\text { FSP401A }\end{array}$ & $\begin{array}{l}\text { F. erosus, differ } \\
\text { by } 1.7-2.0 \%\end{array}$ & $\begin{array}{l}\text { Bob Creek, Lassen } \\
\text { Co., CA }\end{array}$ & \\
\hline & FSP401A & AY962911 & 1 & $0 \%$ & $\begin{array}{l}0.8 \% \text { with } \\
\text { SP400A }\end{array}$ & $\begin{array}{c}\text { F. erosus, differ } \\
\text { by } 1.5-1.8 \%\end{array}$ & $\begin{array}{l}\text { Davis Creek, Lassen } \\
\text { Co., CA }\end{array}$ & \\
\hline & SP402A & AY962912 & 1 & $0 \%$ & $\begin{array}{l}0.6 \% \text { with } \\
\text { SP400A }\end{array}$ & $\begin{array}{c}\text { F. erosus, differ } \\
\text { by } 1.4-1.7 \%\end{array}$ & $\begin{array}{l}\text { Russell Dairy } \\
\text { Spring, Lassen } \\
\text { Co., CA }\end{array}$ & \\
\hline & SP403B & AY962913 & 1 & $0 \%$ & $\begin{array}{l}0.6 \% \text { with } \\
\text { SP400A }\end{array}$ & $\begin{array}{c}\text { F. erosus, differ } \\
\text { by } 1.4-1.7 \%\end{array}$ & $\begin{array}{l}\text { Spring run west of } \\
\text { Russell Dairy } \\
\text { Spring, Lassen } \\
\text { Co., CA }\end{array}$ & \\
\hline & SP404A & AY962914 & 1 & $0 \%$ & $\begin{array}{l}0.6 \% \text { with } \\
\text { SP400A }\end{array}$ & $\begin{array}{c}\text { F. erosus, differ } \\
\text { by } 1.4-1.7 \%\end{array}$ & $\begin{array}{l}\text { Second spring west } \\
\text { of Russell Dairy } \\
\text { Spring, Lassen } \\
\text { Co., CA }\end{array}$ & \\
\hline \multirow[t]{4}{*}{$\begin{array}{l}\text { Fluminicola } \\
\text { coloradoense }\end{array}$} & F01 & JQ996156 & 6 & $0 \%$ & $\begin{array}{c}0.6-0.8 \% \text { with } \\
\text { F13, F60 }\end{array}$ & $\begin{array}{l}\text { F. fuscus, differ } \\
\text { by } 3.9-4.3 \%\end{array}$ & $\begin{array}{l}\text { Portneuf River, } \\
\text { upper access area, } \\
\text { Bannock Co., ID }\end{array}$ & \\
\hline & F02 & $\begin{array}{c}\text { JQ996157 } \\
(n=1), \\
\text { JQ996158 } \\
(n=1), \\
\text { JQ996159 } \\
(n=1), \\
\text { JQ996160 } \\
(n=2)\end{array}$ & 5 & $0-0.6 \%$ & $\begin{array}{c}0.9-1.4 \% \text { with } \\
\text { F60 }\end{array}$ & $\begin{array}{l}\text { F. fuscus, differ } \\
\text { by } 4.3-4.7 \%\end{array}$ & $\begin{array}{l}\text { Snake River, Shelley, } \\
\text { Bingham Co., ID }\end{array}$ & \\
\hline & F04 & JQ996161 & 3 & $0 \%$ & $\begin{array}{c}0.8-0.9 \% \text { with } \\
\text { F13, F60 }\end{array}$ & $\begin{array}{l}\text { F. fuscus, differ } \\
\text { by } 4.1-4.4 \%\end{array}$ & $\begin{array}{l}\text { Blackfoot River, The } \\
\text { Narrows, ca. } 1.5 \mathrm{~km} \\
\text { above weir, Caribou } \\
\text { Co., ID }\end{array}$ & \\
\hline & F05 & JQ996156 & 5 & $0 \%$ & $\begin{array}{l}0.6-0.8 \% \text { with } \\
\text { F13, F60 }\end{array}$ & $\begin{array}{l}\text { F. fuscus, differ } \\
\text { by } 3.9-4.3 \%\end{array}$ & $\begin{array}{l}\text { Raft River, The } \\
\text { Narrows bridge, } \\
\text { Cassia Co., ID }\end{array}$ & \\
\hline
\end{tabular}




\begin{tabular}{|c|c|c|c|c|c|c|c|c|}
\hline Species & $\begin{array}{l}\text { Published } \\
\text { Sample } \\
\text { Codes }\end{array}$ & $\begin{array}{l}\text { Accession } \\
\text { Numbers }\end{array}$ & $\begin{array}{c}\text { No. of } \\
\text { Specimens (N) }\end{array}$ & $\begin{array}{l}\text { Sequence } \\
\text { Variation } \\
\text { (\% pairwise } \\
\text { distance) }\end{array}$ & $\begin{array}{l}\text { Most Distant } \\
\text { Conspecific } \\
\text { Sequences (\%) }\end{array}$ & $\begin{array}{c}\text { Closest } \\
\text { Interspecific } \\
\text { Sequences (\%) }\end{array}$ & Collection Locality & Comments \\
\hline \multirow[t]{16}{*}{$\begin{array}{l}\text { Fluminicola } \\
\text { coloradoense } \\
\text { (continued) }\end{array}$} & F07 & JQ996156 & 5 & $0 \%$ & $\begin{array}{l}0.6-0.8 \% \text { with } \\
\text { F13, F60 }\end{array}$ & $\begin{array}{l}\text { F. fuscus, differ } \\
\text { by } 3.9-4.3 \%\end{array}$ & $\begin{array}{l}\text { Summit Creek, BLM } \\
\text { camp, Custer Co., ID }\end{array}$ & \\
\hline & F08 & $\begin{array}{l}J Q 996156 \\
(n=5) \\
J Q 996162 \\
(n=1)\end{array}$ & 6 & $0-0.2 \%$ & $\begin{array}{c}0.6-0.9 \% \text { with } \\
\text { F13, F60 }\end{array}$ & $\begin{array}{l}\text { F. fuscus, differ } \\
\text { by } 3.9-4.4 \%\end{array}$ & $\begin{array}{l}\text { Henrys Fork, Saint } \\
\text { Anthony, Fremont } \\
\text { Co., ID }\end{array}$ & \\
\hline & F09 & JQ996163 & 5 & $0 \%$ & $\begin{array}{c}0.8-0.9 \% \text { with } \\
\text { F13, F60 }\end{array}$ & $\begin{array}{l}\text { F. fuscus, differ } \\
\text { by } 4.1-4.4 \%\end{array}$ & $\begin{array}{l}\text { Birch Creek, Mud } \\
\text { Creek, Lemhi Co., ID }\end{array}$ & \\
\hline & F10 & $\begin{array}{c}\text { JQ996164 } \\
(n=4) \\
\text { JQ996165 } \\
(n=1)\end{array}$ & 5 & $0-0.2 \%$ & $\begin{array}{c}0.8-1.1 \% \text { with } \\
\text { F60 }\end{array}$ & $\begin{array}{l}\text { F. fuscus, differ } \\
\text { by } 3.8-4.3 \%\end{array}$ & $\begin{array}{l}\text { Little Wood River, } \\
\text { Jim Brown bridge, } \\
\text { Lincoln Co., ID }\end{array}$ & \\
\hline & $\mathrm{F} 12$ & JQ996165 & 5 & $0 \%$ & $\begin{array}{c}0.9-1.1 \% \text { with } \\
\text { F60 }\end{array}$ & $\begin{array}{l}\text { F. fuscus, differ } \\
\text { by } 3.9-4.3 \%\end{array}$ & $\begin{array}{l}\text { Snake River, above } \\
\text { Eagle Rock, Power } \\
\text { Co., ID }\end{array}$ & \\
\hline & F13 & $\begin{array}{c}\text { JQ996166 } \\
(n=4) \\
\text { JQ996167 } \\
(n=1)\end{array}$ & 5 & $0-0.2 \%$ & $\begin{array}{c}1.3-1.6 \% \text { with } \\
\text { F60 }\end{array}$ & $\begin{array}{l}\text { F. fuscus, differ } \\
\text { by } 4.4-5.0 \%\end{array}$ & $\begin{array}{l}\text { Teton River, Buxton } \\
\text { bridge, Teton Co., ID }\end{array}$ & \\
\hline & F14 & $\begin{array}{c}\text { JQ996168 } \\
(n=2), \\
\text { JQ996156 } \\
(n=1) \\
\text { JQ996169 } \\
(n=1), \\
\text { JQ996170 } \\
(n=1)\end{array}$ & 5 & $0-0.5 \%$ & $\begin{array}{c}0.6-1.1 \% \text { with } \\
\text { F60 }\end{array}$ & $\begin{array}{l}\text { F. fuscus, differ } \\
\text { by } 3.9-4.6 \%\end{array}$ & $\begin{array}{l}\text { Snake River, above } \\
\text { Murtaugh, Twin } \\
\text { Falls Co., ID }\end{array}$ & \\
\hline & F15 & JQ996160 & 5 & $0 \%$ & $\begin{array}{c}0.9-1.1 \% \text { with } \\
\text { F60 }\end{array}$ & $\begin{array}{l}\text { F. fuscus, differ } \\
\text { by } 4.3-4.6 \%\end{array}$ & $\begin{array}{l}\text { Salt River, Freedom, } \\
\text { Lincoln Co., WY }\end{array}$ & \\
\hline & F16 & $\begin{array}{c}\text { JQ996160 } \\
(n=7) \\
\text { JQ996163 } \\
(n=1)\end{array}$ & 8 & $0-0.5 \%$ & $\begin{array}{c}0.8-1.1 \% \text { with } \\
\text { F60 }\end{array}$ & $\begin{array}{l}\text { F. fuscus, differ } \\
\text { by } 4.1-4.6 \%\end{array}$ & $\begin{array}{l}\text { Bear River, Black } \\
\text { Canyon, above } \\
\text { Grace Power Plant, } \\
\text { Caribou Co., ID }\end{array}$ & \\
\hline & $\mathrm{F} 17$ & $\begin{array}{l}\text { JQ996156 } \\
(n=1) \\
\text { JQ996163 } \\
(n=2)\end{array}$ & 3 & $0-0.2 \%$ & $\begin{array}{l}0.6-0.9 \% \text { with } \\
\text { F13, F60 }\end{array}$ & $\begin{array}{l}\text { F. fuscus, differ } \\
\text { by } 3.9-4.4 \%\end{array}$ & $\begin{array}{l}\text { Big Malad Spring, } \\
\text { Oneida Co., ID }\end{array}$ & \\
\hline & F18 & JQ996156 & 3 & $0 \%$ & $\begin{array}{c}0.6-0.8 \% \text { with } \\
\text { F13, F60 }\end{array}$ & $\begin{array}{l}\text { F. fuscus, differ } \\
\text { by } 3.9-4.3 \%\end{array}$ & $\begin{array}{l}\text { Hams Fork, Taylor } \\
\text { Creek, Lincoln Co., } \\
\text { WY }\end{array}$ & \\
\hline & F19 & $\begin{array}{c}\text { JQ996156 } \\
(n=4) \\
\text { JQ996171 } \\
(n=1)\end{array}$ & 5 & $0-0.2 \%$ & $\begin{array}{c}0.6-0.9 \% \text { with } \\
\text { F13, F60 }\end{array}$ & $\begin{array}{l}\text { F. fuscus, differ } \\
\text { by } 3.9-4.4 \%\end{array}$ & $\begin{array}{l}\text { New Fork and } \\
\text { East Fork Rivers, } \\
\text { southwest of New } \\
\text { Fork, Sublette Co., } \\
\text { WY }\end{array}$ & \\
\hline & $\mathrm{F} 20$ & JQ996156 & 3 & $0 \%$ & $\begin{array}{c}0.6-0.8 \% \text { with } \\
\text { F13, F60 }\end{array}$ & $\begin{array}{l}\text { F. fuscus, differ } \\
\text { by } 3.9-4.3 \%\end{array}$ & $\begin{array}{l}\text { Beaver Creek, } \\
\text { below Thorn Creek } \\
\text { confluence, Summit } \\
\text { Co, UT }\end{array}$ & \\
\hline & $\mathrm{F} 21$ & $\begin{array}{c}\text { JQ996156 } \\
(n=3) \\
\text { JQ996172 } \\
(n=1)\end{array}$ & 4 & $0-0.2 \%$ & $\begin{array}{c}0.6-0.9 \% \text { with } \\
\text { F13, F60 }\end{array}$ & $\begin{array}{l}\text { F. fuscus, differ } \\
\text { by } 3.9-4.4 \%\end{array}$ & $\begin{array}{l}\text { East Canyon Creek, } \\
\text { above East Canyon } \\
\text { Reservoir, Morgan } \\
\text { Co., UT }\end{array}$ & \\
\hline & $\mathrm{F} 22$ & JQ996156 & 3 & $0 \%$ & $\begin{array}{c}0.6-0.8 \% \text { with } \\
\text { F13, F60 }\end{array}$ & $\begin{array}{l}\text { F. fuscus, differ } \\
\text { by } 3.9-4.3 \%\end{array}$ & $\begin{array}{l}\text { Strawberry Creek, } \\
\text { above Weber River } \\
\text { confluence, Morgan } \\
\text { Co., UT }\end{array}$ & \\
\hline & F23 & $\begin{array}{c}\text { JQ996165 } \\
(n=3) \\
\text { JQ996173 } \\
(n=1)\end{array}$ & 4 & $0-0.9 \%$ & $\begin{array}{c}0.9-1.4 \% \text { with } \\
\text { F60 }\end{array}$ & $\begin{array}{l}\text { F. fuscus, } \\
\text { differ by } \\
3.9-4.7 \%\end{array}$ & $\begin{array}{l}\text { Murray Spring, } \\
\text { below source, } \\
\text { Cache Co., UT }\end{array}$ & \\
\hline
\end{tabular}




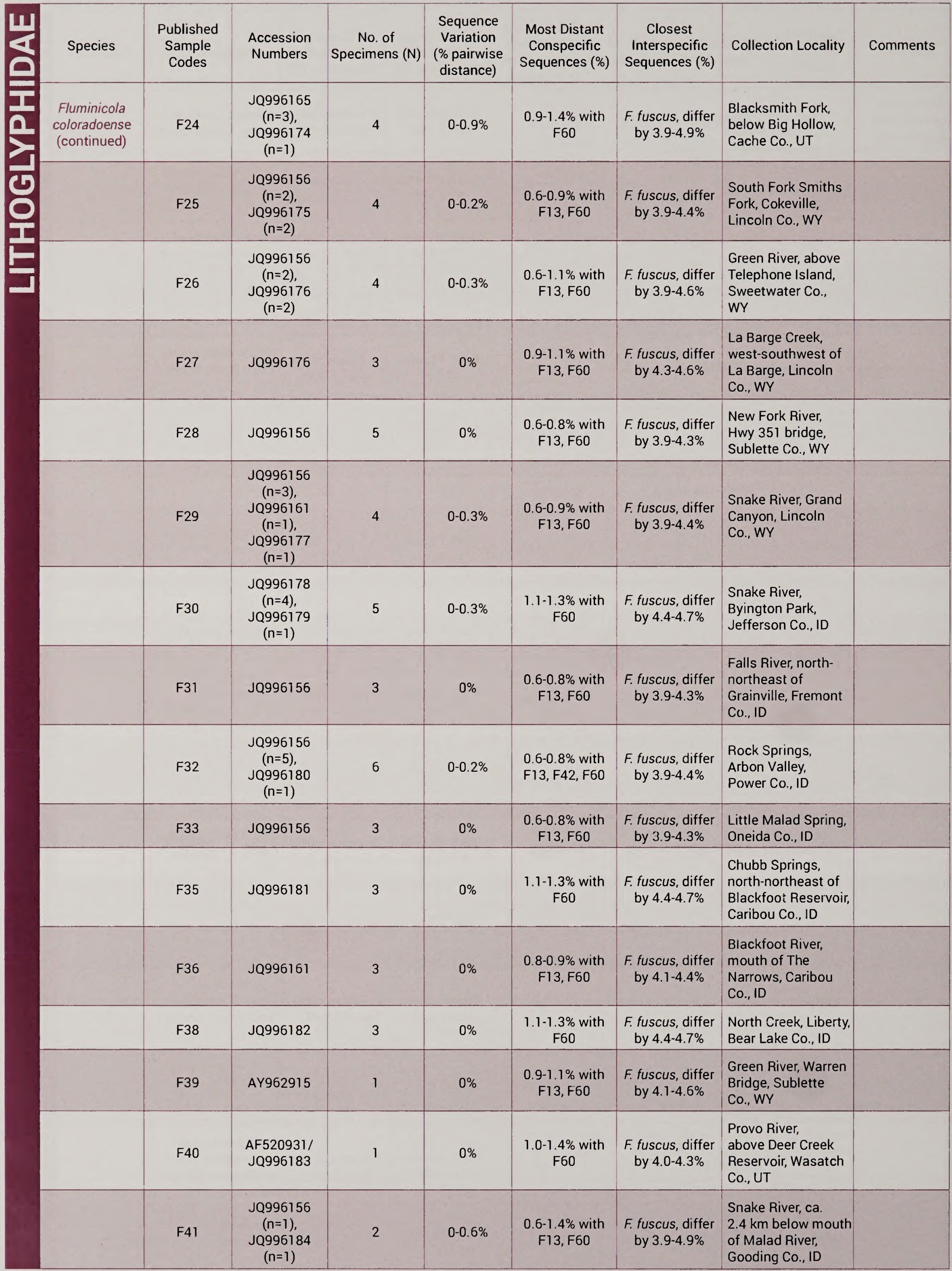




\begin{tabular}{|c|c|c|c|c|c|c|c|c|}
\hline Species & $\begin{array}{l}\text { Published } \\
\text { Sample } \\
\text { Codes }\end{array}$ & $\begin{array}{l}\text { Accession } \\
\text { Numbers }\end{array}$ & $\begin{array}{c}\text { No. of } \\
\text { Specimens }(\mathrm{N})\end{array}$ & $\begin{array}{l}\text { Sequence } \\
\text { Variation } \\
\text { (\% pairwise } \\
\text { distance) }\end{array}$ & $\begin{array}{l}\text { Most Distant } \\
\text { Conspecific } \\
\text { Sequences (\%) }\end{array}$ & $\begin{array}{c}\text { Closest } \\
\text { Interspecific } \\
\text { Sequences (\%) }\end{array}$ & Collection Locality & Comments \\
\hline \multirow[t]{15}{*}{$\begin{array}{l}\text { Fluminicola } \\
\text { coloradoense } \\
\text { (continued) }\end{array}$} & $\mathrm{F} 42$ & $\begin{array}{c}\text { JQ996185 } \\
(n=1) \\
\text { JQ996186 } \\
(n=1)\end{array}$ & 2 & $1.30 \%$ & $\begin{array}{c}0.6-1.4 \% \text { with } \\
\text { F13 }\end{array}$ & $\begin{array}{c}\text { F. fuscus, differ } \\
\text { by } 4.7-4.6 \%\end{array}$ & $\begin{array}{l}\text { Snake River, } \\
\text { Thousand Springs, } \\
\text { Minnie Miller } \\
\text { Springs, Gooding } \\
\text { Co., ID }\end{array}$ & \\
\hline & F43 & JQ996156 & 1 & $0 \%$ & $\begin{array}{c}0.6-0.8 \% \text { with } \\
\text { F13, F60 }\end{array}$ & $\begin{array}{c}\text { F. fuscus, differ } \\
\text { by } 3.9-4.3 \%\end{array}$ & $\begin{array}{l}\text { Snake River, below } \\
\text { Bliss Dam, Gooding } \\
\text { Co., ID }\end{array}$ & \\
\hline & $\mathrm{F} 45$ & $\begin{array}{c}\text { JQ996156 } \\
(n=3) \\
\text { JQ996187 } \\
(n=1) \\
\text { JQ996188 } \\
(n=1)\end{array}$ & 5 & $0-0.8 \%$ & $\begin{array}{c}0.6-1.4 \% \text { with } \\
\text { F13, F60 }\end{array}$ & $\begin{array}{l}\text { F. fuscus, differ } \\
\text { by } 3.9-4.7 \%\end{array}$ & $\begin{array}{l}\text { Deep Creek, above } \\
\text { Stone Canal, Oneida } \\
\text { Co., ID }\end{array}$ & \\
\hline & F47 & JQ996160 & 5 & $0 \%$ & $\begin{array}{c}0.9-1.1 \% \text { with } \\
\text { F60 }\end{array}$ & $\begin{array}{c}\text { F. fuscus, differ } \\
\text { by } 4.3-4.6 \%\end{array}$ & $\begin{array}{l}\text { Snake River, Black } \\
\text { Canyon, Bonneville } \\
\text { Co., ID }\end{array}$ & \\
\hline & F48 & JQ996156 & 5 & $0 \%$ & $\begin{array}{c}0.6-0.8 \% \text { with } \\
\text { F13, F60 }\end{array}$ & $\begin{array}{l}\text { F. fuscus, differ } \\
\text { by } 3.9-4.3 \%\end{array}$ & $\begin{array}{l}\text { Porcupine Station } \\
\text { Springs, Fremont } \\
\text { Co., ID }\end{array}$ & \\
\hline & F49 & JQ996157 & 3 & $0 \%$ & $\begin{array}{c}0.9-1.1 \% \text { with } \\
\text { F60 }\end{array}$ & $\begin{array}{l}\text { F. fuscus, differ } \\
\text { by } 4.3-4.6 \%\end{array}$ & $\begin{array}{l}\text { Willow Creek, } \\
\text { Kepps Crossing, } \\
\text { Bonneville Co., ID }\end{array}$ & \\
\hline & F50 & $\begin{array}{c}\text { JQ996156 } \\
(n=1) \\
\text { JQ996160 } \\
(n=2)\end{array}$ & 3 & $0-0.3 \%$ & $\begin{array}{c}0.6-1.1 \% \text { with } \\
\text { F60 }\end{array}$ & $\begin{array}{c}\text { F. fuscus, differ } \\
\text { by } 3.9-4.6 \%\end{array}$ & $\begin{array}{l}\text { Snake River, Clear } \\
\text { Lake bridge, } \\
\text { Gooding Co., ID }\end{array}$ & \\
\hline & F51 & $\begin{array}{c}\text { JQ996164 } \\
(n=2) \\
\text { JQ996189 } \\
(n=1)\end{array}$ & 3 & $0-0.3 \%$ & $\begin{array}{c}0.8-1.3 \% \text { with } \\
\text { F13, F60 }\end{array}$ & $\begin{array}{c}\text { F. fuscus, differ } \\
\text { by } 3.5-4.3 \%\end{array}$ & $\begin{array}{l}\text { Willow Creek, } \\
\text { Timmerman rest } \\
\text { stop, Blaine Co., ID }\end{array}$ & \\
\hline & F52 & $\begin{array}{c}\text { JQ996164 } \\
(n=1) \\
\text { JQ996190 } \\
(n=1) \\
\text { JQ996191 } \\
(n=1)\end{array}$ & 3 & $0.2-0.8 \%$ & $\begin{array}{c}0.8-1.4 \% \text { with } \\
\text { F13 }\end{array}$ & $\begin{array}{c}\text { F. fuscus, differ } \\
\text { by } 3.8-4.6 \%\end{array}$ & $\begin{array}{l}\text { Big Wood River, } \\
\text { Malad Gorge, } \\
\text { Gooding Co., ID }\end{array}$ & \\
\hline & F53 & JQ996156 & 4 & $0 \%$ & $\begin{array}{c}0.6-0.8 \% \text { with } \\
\text { F13, F60 }\end{array}$ & $\begin{array}{l}\text { F. fuscus, differ } \\
\text { by } 3.9-4.3 \%\end{array}$ & $\begin{array}{l}\text { Crooked Creek, } \\
\text { State Wayside, } \\
\text { Malheur Co., OR }\end{array}$ & \\
\hline & F56 & $\begin{array}{c}\text { JQ996156 } \\
(n=1) \\
\text { JQ996192 } \\
(n=2)\end{array}$ & 3 & $0-0.2 \%$ & $\begin{array}{c}0.6-0.9 \% \text { with } \\
\text { F13, F60 }\end{array}$ & $\begin{array}{l}\text { F. fuscus, differ } \\
\text { by } 3.9-4.4 \%\end{array}$ & $\begin{array}{l}\text { Pahsimeroi River, } \\
\text { Goldburg Creek, } \\
\text { Custer Co., ID }\end{array}$ & \\
\hline & F57 & JQ996156 & 3 & $0 \%$ & $\begin{array}{c}0.6-0.8 \% \text { with } \\
\text { F13, F60 }\end{array}$ & $\begin{array}{c}\text { F. fuscus, differ } \\
\text { by } 3.9-4.3 \%\end{array}$ & $\begin{array}{l}\text { Salmon River, } \\
\text { Kilpatrick, Lemhi } \\
\text { Co., ID }\end{array}$ & \\
\hline & F58 & JQ996156 & 3 & $0 \%$ & $\begin{array}{c}0.6-0.8 \% \text { with } \\
\text { F13, F60 }\end{array}$ & $\begin{array}{c}\text { F. fuscus, differ } \\
\text { by } 3.9-4.3 \%\end{array}$ & $\begin{array}{l}\text { Salmon River, } \\
\text { Mackay Bar, Idaho } \\
\text { Co., ID }\end{array}$ & \\
\hline & F59 & JQ996156 & 3 & $0 \%$ & $\begin{array}{l}0.6-0.8 \% \text { with } \\
\text { F13, F60 }\end{array}$ & $\begin{array}{l}\text { F. fuscus, differ } \\
\text { by } 3.9-4.3 \%\end{array}$ & $\begin{array}{l}\text { Salmon River, } \\
\text { Gasper Creek, Idaho } \\
\text { Co., ID }\end{array}$ & \\
\hline & F60 & $\begin{array}{c}\text { JQ996193 } \\
(n=2) \\
\text { JQ996194 } \\
(n=1)\end{array}$ & 3 & $0-0.8 \%$ & $\begin{array}{c}1.3-1.6 \% \text { with } \\
\text { F13 }\end{array}$ & $\begin{array}{l}\text { F. fuscus, differ } \\
\text { by } 4.1-4.7 \%\end{array}$ & $\begin{array}{l}\text { Len Lewis spring, } \\
\text { Hagerman National } \\
\text { Fish Hatchery, } \\
\text { Gooding Co., ID }\end{array}$ & \\
\hline
\end{tabular}




\begin{tabular}{|c|c|c|c|c|c|c|c|c|}
\hline Species & $\begin{array}{l}\text { Published } \\
\text { Sample } \\
\text { Codes }\end{array}$ & $\begin{array}{l}\text { Accession } \\
\text { Numbers }\end{array}$ & $\begin{array}{c}\text { No. of } \\
\text { Specimens }(\mathrm{N})\end{array}$ & $\begin{array}{l}\text { Sequence } \\
\text { Variation } \\
\text { (\% pairwise } \\
\text { distance) }\end{array}$ & $\begin{array}{l}\text { Most Distant } \\
\text { Conspecific } \\
\text { Sequences (\%) }\end{array}$ & $\begin{array}{c}\text { Closest } \\
\text { Interspecific } \\
\text { Sequences (\%) }\end{array}$ & Collection Locality & Comments \\
\hline \multirow[t]{2}{*}{$\begin{array}{l}\text { Fluminicola } \\
\text { coloradoense } \\
\text { (continued) }\end{array}$} & F61 & $\begin{array}{l}J Q 996186 \\
(n=2) \\
J Q 996195 \\
(n=1)\end{array}$ & 3 & $0-0.5 \%$ & $\begin{array}{c}1.1-1.4 \% \text { with } \\
\text { F60 }\end{array}$ & $\begin{array}{l}\text { F. fuscus, differ } \\
\text { by } 4.3-4.7 \%\end{array}$ & $\begin{array}{l}\text { Thousand Springs, } \\
\text { power plant outflow } \\
\text { just above bridge, } \\
\text { Gooding Co., ID }\end{array}$ & \\
\hline & F63 & $\begin{array}{c}\text { JQ996156 } \\
(n=2) \\
\text { JQ996196 } \\
(n=1)\end{array}$ & 3 & $0-0.2 \%$ & $\begin{array}{l}0.6-0.9 \% \text { with } \\
\text { F13, F60 }\end{array}$ & $\begin{array}{l}\text { F. fuscus, differ } \\
\text { by } 3.9-4.4 \%\end{array}$ & $\begin{array}{l}\text { Snake River, King } \\
\text { Hill SA, Elmore } \\
\text { Co., ID }\end{array}$ & \\
\hline $\begin{array}{l}\text { Fuminicola } \\
\text { dalli }\end{array}$ & D43A & AY962916 & 1 & $0 \%$ & & $\begin{array}{c}\text { F. anserinus, } \\
\text { differ by } \\
3.8-4.1 \% \text {, } \\
\text { F. fremonti, } \\
\text { differ by } 3.8 \% \text {, } \\
\text { F. multifarius, } \\
\text { differ by } \\
3.2-4.6 \% \text {, } \\
\text { F. umbilicatus, } \\
\text { differ by } \\
3.8-4.0 \%\end{array}$ & $\begin{array}{l}\text { Spring west of } \\
\text { Thunderbolt Bay, } \\
\text { Washoe Co., NV }\end{array}$ & \\
\hline \multirow[t]{2}{*}{$\begin{array}{l}\text { Fluminicola } \\
\text { erosus }\end{array}$} & $\begin{array}{l}\text { F11_200B, } \\
\text { F12_200E }\end{array}$ & $\begin{array}{l}\text { AY962918 } \\
\text { AY962920 }\end{array}$ & 2 & $0.20 \%$ & $\begin{array}{l}0.3-0.5 \% \text { with } \\
\text { F11_202A }\end{array}$ & $\begin{array}{c}\text { F. caballensis, } \\
\text { differ by } \\
1.4-1.8 \% \text {, } \\
\text { F. favillaceus, } \\
\text { differ by } \\
0.9-1.7 \%\end{array}$ & $\begin{array}{l}\text { SmokeyCharley } \\
\text { Spring, Modoc Co., } \\
\text { CA }\end{array}$ & \\
\hline & $\begin{array}{l}\text { F10_202E, } \\
\text { F11_202A, } \\
\text { F12_202A }\end{array}$ & $\begin{array}{l}\text { AY962917 } \\
\text { AY962919 } \\
\text { AY962921 }\end{array}$ & 3 & $0.3-0.6 \%$ & $\begin{array}{l}0.2-0.5 \% \text { with } \\
\text { F11_200B }\end{array}$ & $\begin{array}{l}\text { F. caballensis, } \\
\text { differ by } \\
1.4-2.0 \% \\
\text { F. favillaceus, } \\
\text { differ by } \\
0.9-1.8 \%\end{array}$ & $\begin{array}{l}\text { Spring southeast } \\
\text { of Smokey Charley } \\
\text { Spring, Modoc Co., } \\
\text { CA }\end{array}$ & \\
\hline \multirow[t]{4}{*}{$\begin{array}{l}\text { Fluminicola } \\
\text { favillaceus }\end{array}$} & SP364B & AY962927 & 1 & $0 \%$ & $\begin{array}{l}0.5 \% \text { with } \\
\text { SP510A }\end{array}$ & $\begin{array}{l}\text { F. erosus, differ } \\
\text { by } 1.1-1.4 \%\end{array}$ & $\begin{array}{l}\text { Ash Creek at north } \\
\text { culvert, Lassen } \\
\text { Co., CA }\end{array}$ & \\
\hline & SP487A & AY962928 & 1 & $0 \%$ & $\begin{array}{l}0.6 \% \text { with } \\
\text { SP510A }\end{array}$ & $\begin{array}{l}\text { F. erosus, differ } \\
\text { by } 0.9-1.2 \%\end{array}$ & $\begin{array}{l}\text { Ash Creek above } \\
\text { FS39N50 bridge, } \\
\text { Lassen Co., CA }\end{array}$ & \\
\hline & SP509A & AY962929 & 1 & $0 \%$ & $\begin{array}{l}0.5 \% \text { with } \\
\text { SP487A }\end{array}$ & $\begin{array}{l}\text { F. erosus, differ } \\
\text { by } 1.4-1.7 \%\end{array}$ & $\begin{array}{l}\text { Chisolm Spring, } \\
\text { Lassen Co., CA }\end{array}$ & \\
\hline & SP510A & AY962930 & 1 & $0 \%$ & $\begin{array}{l}0.6 \% \text { with } \\
\text { SP487A }\end{array}$ & $\begin{array}{l}\text { F. erosus, differ } \\
\text { by } 1.5-1.8 \%\end{array}$ & $\begin{array}{l}\text { Ash Creek, south } \\
\text { culvert at Ash } \\
\text { Valley Road } \\
\text { crossing, Lassen } \\
\text { Co., CA }\end{array}$ & \\
\hline $\begin{array}{l}\text { Fluminicola } \\
\text { fremonti }\end{array}$ & $\begin{array}{l}\text { D45aA, } \\
\text { D45aB }\end{array}$ & $\begin{array}{l}\text { AY962931 } \\
\text { AY962932 }\end{array}$ & 2 & $0 \%$ & & $\begin{array}{l}\text { F. anserinus, } \\
\text { differ by } \\
3.5-3.8 \% \\
\text { F. dalli, differ } \\
\text { by } 3.8 \%\end{array}$ & $\begin{array}{l}\text { Hunters Spring, } \\
\text { Lake Co., OR }\end{array}$ & \\
\hline \multirow[t]{2}{*}{$\begin{array}{l}\text { Fuminicola } \\
\text { fuscus }\end{array}$} & F03 & JQ996197 & 8 & $0 \%$ & $\begin{array}{c}0.3-1.6 \% \text { with } \\
\text { F06 }\end{array}$ & $\begin{array}{l}\text { F. coloradoense, } \\
\text { differ by } \\
3.6-4.9 \%\end{array}$ & $\begin{array}{l}\text { Boise River, Willow } \\
\text { Creek, Boise Co., ID }\end{array}$ & \\
\hline & F06 & $\begin{array}{c}\text { JQ996198 } \\
(n=4) \\
\text { JQ996199 } \\
(n=1)\end{array}$ & 5 & $0-1.9 \%$ & $\begin{array}{l}0.5-1.7 \% \text { with } \\
\text { F44, F55, 0.2- } \\
1.9 \% \text { with F46 }\end{array}$ & $\begin{array}{l}\text { F. coloradoense, } \\
\text { differ by } \\
3.6-4.9 \%\end{array}$ & $\begin{array}{l}\text { Owyhee River, } \\
\text { below Whistling } \\
\text { Bird Rapids, } \\
\text { Malheur Co., OR }\end{array}$ & \\
\hline
\end{tabular}




\begin{tabular}{|c|c|c|c|c|c|c|c|c|}
\hline Species & $\begin{array}{l}\text { Published } \\
\text { Sample } \\
\text { Codes }\end{array}$ & $\begin{array}{l}\text { Accession } \\
\text { Numbers }\end{array}$ & $\begin{array}{c}\text { No. of } \\
\text { Specimens }(\mathrm{N})\end{array}$ & $\begin{array}{l}\text { Sequence } \\
\text { Variation } \\
\text { (\% pairwise } \\
\text { distance) }\end{array}$ & $\begin{array}{l}\text { Most Distant } \\
\text { Conspecific } \\
\text { Sequences (\%) }\end{array}$ & $\begin{array}{c}\text { Closest } \\
\text { Interspecific } \\
\text { Sequences (\%) }\end{array}$ & Collection Locality & Comments \\
\hline \multirow[t]{9}{*}{$\begin{array}{l}\text { Fluminicola } \\
\text { fuscus } \\
\text { (continued) }\end{array}$} & F11 & $\begin{array}{l}\text { JQ996197 } \\
(n=4) \\
\text { JQ996200 } \\
(n=1)\end{array}$ & 5 & $0-0.2 \%$ & $\begin{array}{c}0.3-1.7 \% \text { with } \\
\text { F06 }\end{array}$ & $\begin{array}{c}\text { F. coloradoense, } \\
\text { differ by } \\
3.6-5.0 \%\end{array}$ & $\begin{array}{l}\text { Bruneau River, BLM } \\
\text { low site, Owyhee } \\
\text { Co., ID }\end{array}$ & \\
\hline & $\mathrm{F} 44$ & $\begin{array}{l}\text { DQ372901/ } \\
\text { JQ996201 }\end{array}$ & 1 & $0 \%$ & $\begin{array}{c}0.5-1.7 \% \text { with } \\
\text { F06 }\end{array}$ & $\begin{array}{c}\text { F. coloradoense, } \\
\text { differ by } \\
3.8-4.7 \%\end{array}$ & $\begin{array}{l}\text { Grande Ronde } \\
\text { River, } 0.2 \mathrm{~km} \text { above } \\
\text { mouth, Asotin Co., } \\
\text { WA }\end{array}$ & \\
\hline & $\mathrm{F} 46$ & $\begin{array}{c}\text { JQ996202 } \\
(n=4) \\
\text { JQ996203 } \\
(n=1)\end{array}$ & 5 & $0-0.2 \%$ & $\begin{array}{c}0.2-1.9 \% \text { with } \\
\text { F06 }\end{array}$ & $\begin{array}{c}\text { F. coloradoense, } \\
\text { differ by } \\
3.5-4.9 \%\end{array}$ & $\begin{array}{l}\text { Methow River north } \\
\text { of Squaw Creek } \\
\text { mouth, Okanogon } \\
\text { Co., WA }\end{array}$ & \\
\hline & F54 & JQ996197 & 4 & $0 \%$ & $\begin{array}{c}0.3-1.6 \% \text { with } \\
\text { F06 }\end{array}$ & $\begin{array}{c}\text { F. coloradoense, } \\
\text { differ by } \\
3.6-4.9 \%\end{array}$ & $\begin{array}{l}\text { Payette River, } \\
\text { Banks Camp } \\
\text { [Campground], } \\
\text { Boise Co., ID }\end{array}$ & \\
\hline & F55 & JQ996204 & 3 & $0 \%$ & $\begin{array}{c}0.5-1.7 \% \text { with } \\
\text { F06 }\end{array}$ & $\begin{array}{c}\text { F. coloradoense, } \\
\text { differ by } \\
3.8-5.0 \%\end{array}$ & $\begin{array}{l}\text { Imnaha River, Bare } \\
\text { Creek, Wallowa } \\
\text { Co., OR }\end{array}$ & \\
\hline & F62 & JQ996197 & 3 & $0 \%$ & $\begin{array}{c}0.3-1.6 \% \text { with } \\
\text { F06 }\end{array}$ & $\begin{array}{l}\text { F. coloradoense, } \\
\text { differ by } \\
3.6-4.9 \%\end{array}$ & $\begin{array}{l}\text { Snake River, Grand } \\
\text { View SA, Owyhee } \\
\text { Co., ID }\end{array}$ & \\
\hline & F64 & JQ996198 & 3 & $0 \%$ & $\begin{array}{l}0-1.9 \% \text { with } \\
\text { F06 }\end{array}$ & $\begin{array}{l}\text { F. coloradoense, } \\
\text { differ by } \\
3.6-4.9 \%\end{array}$ & $\begin{array}{l}\text { Owyhee River, } \\
\text { above Beaver } \\
\text { Charlie } \\
\text { Cabin, Malheur } \\
\text { Co., OR }\end{array}$ & \\
\hline & F65 & JQ996197 & 4 & $0 \%$ & $\begin{array}{c}0.3-1.6 \% \text { with } \\
\text { F06 }\end{array}$ & $\begin{array}{l}\text { F. coloradoense, } \\
\text { differ by } \\
3.6-4.9 \%\end{array}$ & $\begin{array}{l}\text { Boise River, Willow } \\
\text { Creek, Boise Co., ID }\end{array}$ & \\
\hline & F66 & JQ996197 & 4 & $0 \%$ & $\begin{array}{l}0.3-1.6 \% \text { with } \\
\text { F06 }\end{array}$ & $\begin{array}{c}\text { F. coloradoense, } \\
\text { differ by } \\
3.6-4.9 \%\end{array}$ & $\begin{array}{l}\text { Boise River, } \\
\text { Badger Camp } \\
\text { [Campground], } \\
\text { Boise Co., ID }\end{array}$ & \\
\hline \multirow[t]{5}{*}{$\begin{array}{l}\text { Fluminicola } \\
\text { gustafsoni }\end{array}$} & F67 & $\begin{array}{l}\text { JQ731609 } \\
(n=1) \\
\text { JQ731610 } \\
(n=2)\end{array}$ & 3 & $0-0.2 \%$ & $\begin{array}{c}0.5-0.8 \% \text { with } \\
\text { F73 }\end{array}$ & $\begin{array}{l}\text { F. virens, } \\
\text { differ by } \\
6.5-6.6 \%\end{array}$ & $\begin{array}{l}\text { Clearwater River, } \\
\text { Jim Ford Creek, } \\
\text { Clearwater Co., ID }\end{array}$ & \\
\hline & F68 & JQ731611 & 4 & $0 \%$ & $\begin{array}{c}0.5-0.6 \% \text { with } \\
\text { F73 }\end{array}$ & $\begin{array}{c}\text { F. virens, } \\
\text { differ by } 6.6 \%\end{array}$ & $\begin{array}{l}\text { Clearwater River, } \\
\text { Orofino, Clearwater } \\
\text { Co., ID }\end{array}$ & \\
\hline & F69 & JQ731612 & 3 & $0 \%$ & $\begin{array}{c}0.3-0.5 \% \text { with } \\
\text { F67 }\end{array}$ & $\begin{array}{c}\text { F. virens, } \\
\text { differ by } 6.3 \%\end{array}$ & $\begin{array}{l}\text { Salmon River, Pine } \\
\text { Bar Rapids, Idaho } \\
\text { Co., ID }\end{array}$ & \\
\hline & F70 & JQ731613 & 2 & $0 \%$ & $\begin{array}{c}0.5-0.6 \% \text { with } \\
\text { F73 }\end{array}$ & $\begin{array}{c}\text { F. virens, } \\
\text { differ by } 6.6 \%\end{array}$ & $\begin{array}{l}\text { South Fork } \\
\text { Clearwater River, } \\
\text { Battlefield, Idaho } \\
\text { Co., ID }\end{array}$ & \\
\hline & F73 & $\begin{array}{c}J Q 731614 \\
(n=1) \\
J Q 731615 \\
(n=2)\end{array}$ & 3 & $0-0.6 \%$ & $\begin{array}{c}0.5-0.8 \% \text { with } \\
\text { F67 }\end{array}$ & $\begin{array}{l}\text { F. virens, } \\
\text { differ by } \\
6.2-6.3 \%\end{array}$ & $\begin{array}{l}\text { Snake River, below } \\
\text { mouth of Couse } \\
\text { Creek, Asotin Co., } \\
\text { WA }\end{array}$ & \\
\hline
\end{tabular}




\begin{tabular}{|c|c|c|c|c|c|c|c|c|}
\hline Species & $\begin{array}{l}\text { Published } \\
\text { Sample } \\
\text { Codes }\end{array}$ & $\begin{array}{l}\text { Accession } \\
\text { Numbers }\end{array}$ & $\begin{array}{c}\text { No. of } \\
\text { Specimens }(\mathrm{N})\end{array}$ & $\begin{array}{c}\text { Sequence } \\
\text { Variation } \\
\text { (\% pairwise } \\
\text { distance) }\end{array}$ & $\begin{array}{l}\text { Most Distant } \\
\text { Conspecific } \\
\text { Sequences (\%) }\end{array}$ & $\begin{array}{c}\text { Closest } \\
\text { Interspecific } \\
\text { Sequences (\%) }\end{array}$ & Collection Locality & Comments \\
\hline $\begin{array}{l}\text { Fluminicola } \\
\text { insolitus }\end{array}$ & D35A & AY962934 & 1 & $0 \%$ & & $\begin{array}{l}\text { F. coloradoense, } \\
\text { differ by } \\
8.7-9.8 \% \text {, } \\
\text { F. fuscus, differ } \\
\text { by } 8.8-9.1 \%\end{array}$ & $\begin{array}{l}\text { Page Springs, } \\
\text { Harney Co., OR }\end{array}$ & \\
\hline $\begin{array}{l}\text { Fluminicola } \\
\text { lunsfordensis }\end{array}$ & $\begin{array}{l}\text { F3_59A, } \\
\text { F3_59B }\end{array}$ & $\begin{array}{l}\text { AY962935, } \\
\text { AY962936 }\end{array}$ & 2 & $0 \%$ & & $\begin{array}{c}\text { F. ahjumawi, } \\
\text { differ by } \\
1.9-2.7 \% \\
\text { Fluminicola sp. } \\
\text { B, differ by } \\
2.4-2.5 \%\end{array}$ & $\begin{array}{l}\text { Lunsford Spring, } \\
\text { Modoc Co., CA }\end{array}$ & \\
\hline \multirow[t]{2}{*}{$\begin{array}{l}\text { Fluminicola } \\
\text { modoci }\end{array}$} & D42B & AY962938 & 1 & $0 \%$ & $0.9 \%$ with $\mathrm{D} 40 \mathrm{~A}$ & $\begin{array}{l}\text { F. seminalis, } \\
\text { differ by } \\
5.0-5.6 \%\end{array}$ & $\begin{array}{l}\text { Spring at Three } \\
\text { Springs Ranch, } \\
\text { Modoc Co., CA }\end{array}$ & \\
\hline & D40A & AY962937 & 1 & $0 \%$ & $0.9 \%$ with D42B & $\begin{array}{l}\text { F. seminalis, } \\
\text { differ by } \\
5.6-6.1 \%\end{array}$ & $\begin{array}{l}\text { Link River at } \\
\text { Klamath Falls } \\
\text { bridge, Klamath } \\
\text { Co., OR }\end{array}$ & \\
\hline \multirow[t]{11}{*}{$\begin{array}{l}\text { Fluminicola } \\
\text { multifarius }\end{array}$} & SP8B & AY962939 & 1 & $0 \%$ & $\begin{array}{l}2.9 \% \text { with } \\
\text { F10_99B }\end{array}$ & $\begin{array}{l}\text { F. anserinus, } \\
\text { differ by } \\
3.3-3.6 \%\end{array}$ & $\begin{array}{l}\text { Spring near Conant, } \\
\text { Siskiyou Co., CA }\end{array}$ & \\
\hline & F2_10B & AY962975 & 1 & $0 \%$ & $\begin{array}{l}2.6 \% \text { with } \\
\text { F3_69A }\end{array}$ & $\begin{array}{l}\text { F. anserinus, } \\
\text { differ by } \\
3.0-3.5 \%\end{array}$ & $\begin{array}{l}\text { Ney Springs, } \\
\text { Siskiyou Co., CA }\end{array}$ & \\
\hline & F1_12B & AY962976 & 1 & $0 \%$ & $\begin{array}{c}2.6 \% \text { with } \\
\text { F3_69A }\end{array}$ & $\begin{array}{l}\text { F. anserinus, } \\
\text { differ by } \\
3.0-3.5 \%\end{array}$ & $\begin{array}{l}\text { Sacramento River } \\
\text { near Stink Creek, } \\
\text { Siskiyou Co., CA }\end{array}$ & \\
\hline & F6_27B & AY962940 & 1 & $0 \%$ & $\begin{array}{l}2.9 \% \text { with } \\
\text { F10_99B }\end{array}$ & $\begin{array}{l}\text { F. anserinus, } \\
\text { differ by } \\
3.3-3.6 \%\end{array}$ & $\begin{array}{l}\text { Crystal Spring, } \\
\text { Siskiyou Co., CA }\end{array}$ & \\
\hline & $\begin{array}{l}\text { F4_30A, } \\
\text { F5_30A }\end{array}$ & $\begin{array}{l}\text { AY962941, } \\
\text { AY962942 }\end{array}$ & 2 & $0 \%$ & $\begin{array}{l}2.9 \% \text { with } \\
\text { F10_99B }\end{array}$ & $\begin{array}{l}\text { F. anserinus, } \\
\text { differ by } \\
3.3-3.6 \%\end{array}$ & $\begin{array}{l}\text { Rock Spring, } \\
\text { Siskiyou Co., CA }\end{array}$ & \\
\hline & $\begin{array}{l}\text { F3_65A, } \\
\text { F4_65A, } \\
\text { F5_65A, } \\
\text { FSP65F }\end{array}$ & $\begin{array}{l}\text { AY } 962943, \\
\text { AY962944, } \\
\text { AY } 962945, \\
\text { AY } 962946\end{array}$ & 4 & $0-0.2 \%$ & $\begin{array}{l}2.9 \% \text { with } \\
\text { F10_99B }\end{array}$ & $\begin{array}{l}\text { F. anserinus, } \\
\text { differ by } \\
3.3-3.6 \%\end{array}$ & $\begin{array}{l}\text { Southernmost of } \\
\text { Shasta Springs, } \\
\text { Shasta Co., CA }\end{array}$ & \\
\hline & F4_68A & AY962947 & 1 & $0 \%$ & $\begin{array}{l}2.9 \% \text { with } \\
\text { F10_99B }\end{array}$ & $\begin{array}{l}\text { F. anserinus, } \\
\text { differ by } \\
3.3-3.6 \%\end{array}$ & $\begin{array}{l}\text { Spring north of } \\
\text { Mossbrae Falls, } \\
\text { Shasta Co., CA }\end{array}$ & \\
\hline & F3_69A & AY962948 & 1 & $0 \%$ & $\begin{array}{l}3.0 \% \text { with } \\
\text { F10_99B }\end{array}$ & $\begin{array}{l}\text { F. anserinus, } \\
\text { differ by } \\
3.5-3.8 \%\end{array}$ & $\begin{array}{l}\text { Spring runs north } \\
\text { of Mossbrae Falls, } \\
\text { Shasta Co., CA }\end{array}$ & \\
\hline & F10_99B & AY962977 & 1 & $0 \%$ & $\begin{array}{l}3.0 \% \text { with } \\
\text { F3_69A }\end{array}$ & $\begin{array}{l}\text { F. anserinus, } \\
\text { differ by } \\
2.6-2.9 \%\end{array}$ & $\begin{array}{l}\text { Big Springs } \\
\text { (source), northwest } \\
\text { of city of Mount } \\
\text { Shasta, Shasta } \\
\text { Co., CA }\end{array}$ & \\
\hline & $\mathrm{F} 1 \_140 \mathrm{~A}$ & AY962949 & 1 & $0 \%$ & $\begin{array}{l}2.9 \% \text { with } \\
\text { F10_99B }\end{array}$ & $\begin{array}{l}\text { F. anserinus, } \\
\text { differ by } \\
3.3-3.6 \%\end{array}$ & $\begin{array}{l}\text { Sacramento River } \\
\text { at Cave Springs, } \\
\text { Siskiyou Co., CA }\end{array}$ & \\
\hline & F2_143A & AY962978 & 1 & $0 \%$ & $\begin{array}{l}2.7 \% \text { with } \\
\text { F3_69A }\end{array}$ & $\begin{array}{l}\text { F. anserinus, } \\
\text { differ by } \\
2.6-3.0 \%\end{array}$ & $\begin{array}{l}\text { Spring along } \\
\text { Sacramento River } \\
\text { (third to the) east } \\
\text { of Cantara Bend, } \\
\text { Siskiyou Co., CA }\end{array}$ & \\
\hline
\end{tabular}




\begin{tabular}{|c|c|c|c|c|c|c|c|c|}
\hline Species & $\begin{array}{l}\text { Published } \\
\text { Sample } \\
\text { Codes }\end{array}$ & $\begin{array}{l}\text { Accession } \\
\text { Numbers }\end{array}$ & $\begin{array}{c}\text { No. of } \\
\text { Specimens (N) }\end{array}$ & $\begin{array}{l}\text { Sequence } \\
\text { Variation } \\
\text { (\% pairwise } \\
\text { distance) }\end{array}$ & $\begin{array}{c}\text { Most Distant } \\
\text { Conspecific } \\
\text { Sequences (\%) }\end{array}$ & $\begin{array}{c}\text { Closest } \\
\text { Interspecific } \\
\text { Sequences (\%) }\end{array}$ & Collection Locality & Comments \\
\hline \multirow[t]{8}{*}{$\begin{array}{l}\text { Fluminicola } \\
\text { multifarius } \\
\text { (continued) }\end{array}$} & F2_144A & AY962979 & 1 & $0 \%$ & $\begin{array}{c}2.6 \% \text { with } \\
\text { F3_69A }\end{array}$ & $\begin{array}{l}\text { F. anserinus, } \\
\text { differ by } \\
3.0-3.5 \%\end{array}$ & $\begin{array}{l}\text { Spring along } \\
\text { Sacramento River } \\
\text { (first to the) east } \\
\text { of Cantara Bend, } \\
\text { Siskiyou Co., CA }\end{array}$ & \\
\hline & SP237A & AY962980 & 1 & $0 \%$ & $\begin{array}{l}2.4 \% \text { with } \\
\text { F3_69A, } \\
\text { F10_322B }\end{array}$ & $\begin{array}{l}\text { F. anserinus, } \\
\text { differ by } \\
3.2-3.6 \%\end{array}$ & $\begin{array}{l}\text { Big Springs, three } \\
\text { middle runs, } \\
\text { Siskiyou Co., CA }\end{array}$ & \\
\hline & SP238B & AY962981 & 1 & $0 \%$ & $\begin{array}{l}\text { 2.4\% with } \\
\text { F3_69A, } \\
\text { F10_322B }\end{array}$ & $\begin{array}{l}\text { F. anserinus, } \\
\text { differ by } \\
3.2-3.6 \%\end{array}$ & $\begin{array}{l}\text { Big Springs, } \\
\text { westernmost run, } \\
\text { Siskiyou Co., CA }\end{array}$ & \\
\hline & F10_239B & AY962982 & 1 & $0 \%$ & $\begin{array}{c}2.7 \% \text { with } \\
\text { F3_69A }\end{array}$ & $\begin{array}{l}\text { F. anserinus, } \\
\text { differ by } \\
2.9-3.3 \%\end{array}$ & $\begin{array}{l}\text { Big Springs, } \\
\text { easternmost run, } \\
\text { Siskiyou Co., CA }\end{array}$ & \\
\hline & SP241A & AY962983 & 1 & $0 \%$ & $\begin{array}{c}2.6 \% \text { with } \\
\text { F3_69A }\end{array}$ & $\begin{array}{l}\text { F. anserinus, } \\
\text { differ by } \\
3.0-3.5 \%\end{array}$ & $\begin{array}{l}\text { Big Springs at } \\
\text { west side of park, } \\
\text { Siskiyou Co., CA }\end{array}$ & \\
\hline & F10_322B & AY962950 & 1 & $0 \%$ & $\begin{array}{l}2.7 \% \text { with } \\
\text { F10_99B }\end{array}$ & $\begin{array}{l}\text { F. anserinus, } \\
\text { differ by } \\
3.2-3.5 \%\end{array}$ & $\begin{array}{l}\text { Bundoora Spring, } \\
\text { Siskiyou Co., CA }\end{array}$ & \\
\hline & F3_330A & AY962951 & 1 & $0 \%$ & $\begin{array}{l}2.9 \% \text { with } \\
\text { F10_99B }\end{array}$ & $\begin{array}{l}\text { F. anserinus, } \\
\text { differ by } \\
3.3-3.6 \%\end{array}$ & $\begin{array}{l}\text { Spring north of } \\
\text { Crystal Spring, } \\
\text { Siskiyou Co., CA }\end{array}$ & \\
\hline & ELKSPB & AY962952 & 1 & $0 \%$ & $\begin{array}{l}2.6 \% \text { with } \\
\text { F10_99B }\end{array}$ & $\begin{array}{l}\text { F. anserinus, } \\
\text { differ by } \\
3.0-3.3 \%\end{array}$ & $\begin{array}{l}\text { Elk Spring } \\
\text { (lowermost), } \\
\text { Siskiyou Co., CA }\end{array}$ & \\
\hline \multirow[t]{3}{*}{$\begin{array}{l}\text { Fluminicola } \\
\text { neritoides }\end{array}$} & F9_369B & AY962953 & 1 & $0 \%$ & no variation & $\begin{array}{l}\text { F. lunsfordensis, } \\
\text { differ by } 4.9 \%\end{array}$ & $\begin{array}{l}\text { Willow Creek at } \\
\text { mouth of Hayden } \\
\text { Canyon, Lassen } \\
\text { Co., CA }\end{array}$ & \\
\hline & F9_371A & AY962954 & 1 & $0 \%$ & no variation & $\begin{array}{l}\text { F. lunsfordensis, } \\
\text { differ by } 4.9 \%\end{array}$ & $\begin{array}{l}\text { Willow Creek at } \\
\text { lower end of Lower } \\
\text { McBride Springs, } \\
\text { Lassen Co., CA }\end{array}$ & \\
\hline & F9_372A & AY962955 & 1 & $0 \%$ & no variation & $\begin{array}{l}\text { F. lunsfordensis, } \\
\text { differ by } 4.9 \%\end{array}$ & $\begin{array}{l}\text { Willow Creek west } \\
\text { of Hayden Hill, } \\
\text { Lassen Co., CA }\end{array}$ & \\
\hline $\begin{array}{l}\text { Fluminicola } \\
\text { potemicus }\end{array}$ & $\begin{array}{l}\text { F2_36A, } \\
\text { F2_36B }\end{array}$ & $\begin{array}{l}\text { AY962956, } \\
\text { AY962957 }\end{array}$ & 2 & $0 \%$ & & $\begin{array}{l}\text { F. anserinus, } \\
\text { differ by } \\
3.5-4.1 \% \text {, } \\
\text { F. multifarius, } \\
\text { differ by } \\
3.2-3.8 \% \text {, } \\
\text { F. umbilicatus, } \\
\text { differ by } \\
3.6-3.8 \%\end{array}$ & $\begin{array}{l}\text { Spring near Potem } \\
\text { Creek, Shasta Co., } \\
\text { CA }\end{array}$ & \\
\hline $\begin{array}{l}\text { Fluminicola } \\
\text { scopulinus }\end{array}$ & F14_251B & AY962958 & 1 & $0 \%$ & $\begin{array}{l}0.5 \% \text { with } \\
\text { F14_303B }\end{array}$ & $\begin{array}{l}\text { F. anserinus, } \\
\text { differ by } \\
3.8-4.0 \% \text {, } \\
\text { F. multifarius, } \\
\text { differ by } \\
3.5-4.3 \% \text {, }\end{array}$ & $\begin{array}{l}\text { Northernmost } \\
\text { spring southwest } \\
\text { of Popcorn Spring, } \\
\text { Shasta Co., CA }\end{array}$ & \\
\hline
\end{tabular}




\begin{tabular}{|c|c|c|c|c|c|c|c|c|}
\hline Species & $\begin{array}{l}\text { Published } \\
\text { Sample } \\
\text { Codes }\end{array}$ & $\begin{array}{c}\text { Accession } \\
\text { Numbers }\end{array}$ & $\begin{array}{c}\text { No. of } \\
\text { Specimens }(\mathrm{N})\end{array}$ & $\begin{array}{c}\text { Sequence } \\
\text { Variation } \\
\text { (\% pairwise } \\
\text { distance) }\end{array}$ & $\begin{array}{c}\text { Most Distant } \\
\text { Conspecific } \\
\text { Sequences (\%) }\end{array}$ & $\begin{array}{c}\text { Closest } \\
\text { Interspecific } \\
\text { Sequences (\%) }\end{array}$ & Collection Locality & Comments \\
\hline $\begin{array}{l}\text { Fluminicola } \\
\text { scopulinus } \\
\text { (continued) }\end{array}$ & F14_303B & AY962959 & 1 & $0 \%$ & $\begin{array}{l}0.5 \% \text { with } \\
\text { F14_251B }\end{array}$ & $\begin{array}{c}\text { F. anserinus, } \\
\text { differ by } \\
4.3-4.4 \% \text {, } \\
\text { F. multifarius, } \\
\text { differ by } \\
3.6-4.4 \%\end{array}$ & $\begin{array}{l}\text { Northernmost } \\
\text { spring west of } \\
\text { Popcorn Spring, } \\
\text { Shasta Co., CA }\end{array}$ & \\
\hline \multirow[t]{14}{*}{$\begin{array}{l}\text { Fluminicola } \\
\text { seminalis }\end{array}$} & sem98B & AY962960 & 1 & $0 \%$ & $\begin{array}{l}1.2 \% \text { with } \\
\text { sem } 329 A\end{array}$ & $\begin{array}{l}\text { F. modoci, } \\
\text { differ by } \\
5.5-5.9 \% \\
\end{array}$ & $\begin{array}{l}\text { Big Lake outlet near } \\
\text { Rat Farm, Shasta } \\
\text { Co., CA }\end{array}$ & \\
\hline & sem104B & AY962961 & 1 & $0 \%$ & $\begin{array}{c}1.2 \% \text { with } \\
\text { D38, SP366B, } \\
\text { sem426A, } \\
\text { Fsem532A, } \\
\text { Fsem552A }\end{array}$ & $\begin{array}{l}\text { F. modoci, } \\
\text { differ by } \\
5.2-5.8 \%\end{array}$ & $\begin{array}{l}\text { Baum Lake (deep- } \\
\text { water site), Shasta } \\
\text { Co., CA }\end{array}$ & \\
\hline & sem105A & AY962962 & 1 & $0 \%$ & $\begin{array}{l}1.2 \% \text { with } \\
\text { sem } 329 \mathrm{~A}\end{array}$ & $\begin{array}{l}\text { F. modoci, } \\
\text { differ by } \\
5.5-5.9 \%\end{array}$ & $\begin{array}{l}\text { Fall River at } \\
\text { CalTrout Public } \\
\text { Fishing Access } \\
\text { Area, Shasta } \\
\text { Co., CA }\end{array}$ & \\
\hline & sem329A & AY962963 & 1 & $0 \%$ & $\begin{array}{c}\text { 1.4\% with } \\
\text { D38, SP366B, } \\
\text { sem426A, } \\
\text { Fsem532A, } \\
\text { Fsem552A }\end{array}$ & $\begin{array}{l}\text { F. modoci, } \\
\text { differ by } \\
5.2-5.8 \%\end{array}$ & $\begin{array}{l}\text { Baum Lake } \\
\text { (shallow-water site), } \\
\text { Shasta Co., CA }\end{array}$ & \\
\hline & D38A & AY962964 & 1 & $0 \%$ & $\begin{array}{l}1.4 \% \text { with } \\
\text { sem } 329 \mathrm{~A}\end{array}$ & $\begin{array}{l}\text { F. modoci, } \\
\text { differ by } \\
5.3-5.8 \%\end{array}$ & $\begin{array}{l}\text { Battle Creek east } \\
\text { of Coleman Fish } \\
\text { Hatchery, Shasta } \\
\text { Co., CA }\end{array}$ & \\
\hline & sem364A & AY962965 & 1 & $0 \%$ & $\begin{array}{c}\text { 1.4\% with D38, } \\
\text { sem } 426 \mathrm{~A}, \\
\text { Fsem } 532 \mathrm{~A} \\
\text { Fsem } 552 \mathrm{~A}\end{array}$ & $\begin{array}{l}\text { F. modoci, } \\
\text { differ by } \\
5.0-5.6 \%\end{array}$ & $\begin{array}{l}\text { Ash Creek at north } \\
\text { culvert, Lassen } \\
\text { Co., CA }\end{array}$ & \\
\hline & SP366B & AY962966 & 1 & $0 \%$ & $\begin{array}{l}1.4 \% \text { with } \\
\text { sem } 329 \mathrm{~A}\end{array}$ & $\begin{array}{l}\text { F. modoci, } \\
\text { differ by } \\
5.3-5.8 \%\end{array}$ & $\begin{array}{l}\text { Ash Creek } \\
\text { northwest of Ash } \\
\text { Creek Campground, } \\
\text { Lassen Co., CA }\end{array}$ & \\
\hline & sem411A & AY962967 & 1 & $0 \%$ & $\begin{array}{l}1.2 \% \text { with } \\
\text { sem } 329 \mathrm{~A}\end{array}$ & $\begin{array}{l}\text { F. modoci, } \\
\text { differ by } \\
5.5-5.9 \%\end{array}$ & $\begin{array}{l}\text { Crystal Springs, } \\
\text { Shasta Co., CA }\end{array}$ & \\
\hline & sem416A & AY962968 & 1 & $0 \%$ & $\begin{array}{l}1.2 \% \text { with } \\
\text { sem } 329 A\end{array}$ & $\begin{array}{l}\text { F. modoci, } \\
\text { differ by } \\
5.5-5.9 \%\end{array}$ & $\begin{array}{l}\text { Big Lake Springs, } \\
\text { Shasta Co., CA }\end{array}$ & \\
\hline & sem $425 A$ & AY962969 & 1 & $0 \%$ & $\begin{array}{l}1.2 \% \text { with } \\
\text { sem } 329 A\end{array}$ & $\begin{array}{l}\text { F. modoci, } \\
\text { differ by } \\
5.5-5.9 \%\end{array}$ & $\begin{array}{l}\text { Pit River near } \\
\text { confluence of Hat } \\
\text { Creek, Shasta Co., } \\
\text { CA }\end{array}$ & \\
\hline & sem $426 A$ & AY962970 & 1 & $0 \%$ & $\begin{array}{l}1.4 \% \text { with } \\
\text { sem } 329 A\end{array}$ & $\begin{array}{l}\text { F. modoci, } \\
\text { differ by } \\
5.6-6.1 \%\end{array}$ & $\begin{array}{l}\text { Spring Creek on } \\
\text { south side of Spring } \\
\text { Creek Road, Shasta } \\
\text { Co., CA }\end{array}$ & \\
\hline & sem487A & AY962971 & 1 & $0 \%$ & $\begin{array}{l}1.2 \% \text { with } \\
\text { sem } 329 \mathrm{~A}\end{array}$ & $\begin{array}{l}\text { F. modoci, } \\
\text { differ by } \\
5.2-5.6 \%\end{array}$ & $\begin{array}{l}\text { Ash Creek above } \\
\text { FS39N50 bridge, } \\
\text { Lassen Co., CA }\end{array}$ & \\
\hline & Fsem532A & AY962972 & 1 & $0 \%$ & $\begin{array}{l}1.4 \% \text { with } \\
\text { sem } 329 \mathrm{~A}\end{array}$ & $\begin{array}{l}\text { F. modoci, } \\
\text { differ by } \\
5.6-6.1 \%\end{array}$ & $\begin{array}{l}\text { Lava Creek at } \\
\text { boathouse on } \\
\text { Hanna Estate, } \\
\text { Shasta Co., CA }\end{array}$ & \\
\hline & Fsem546A & AY962973 & 1 & $0 \%$ & $\begin{array}{l}1.2 \% \text { with } \\
\text { sem } 329 \mathrm{~A}\end{array}$ & $\begin{array}{l}\text { F. modoci, } \\
\text { differ by } \\
5.5-5.9 \%\end{array}$ & $\begin{array}{l}\text { Spring on west side } \\
\text { of Spring Creek, } \\
\text { Shasta Co., CA }\end{array}$ & \\
\hline
\end{tabular}




\begin{tabular}{|c|c|c|c|c|c|c|c|c|}
\hline Species & $\begin{array}{l}\text { Published } \\
\text { Sample } \\
\text { Codes }\end{array}$ & $\begin{array}{l}\text { Accession } \\
\text { Numbers }\end{array}$ & $\begin{array}{c}\text { No. of } \\
\text { Specimens }(\mathrm{N})\end{array}$ & $\begin{array}{c}\text { Sequence } \\
\text { Variation } \\
\text { (\% pairwise } \\
\text { distance) }\end{array}$ & $\begin{array}{l}\text { Most Distant } \\
\text { Conspecific } \\
\text { Sequences (\%) }\end{array}$ & $\begin{array}{c}\text { Closest } \\
\text { Interspecific } \\
\text { Sequences (\%) }\end{array}$ & Collection Locality & Comments \\
\hline $\begin{array}{l}\text { Fluminicola } \\
\text { seminalis } \\
\text { (continued) }\end{array}$ & Fsem552A & AY962974 & 1 & $0 \%$ & $\begin{array}{l}1.4 \% \text { with } \\
\text { sem } 329 A\end{array}$ & $\begin{array}{l}\text { F. modoci, } \\
\text { differ by } \\
5.6-6.1 \%\end{array}$ & $\begin{array}{l}\text { Lava Creek source } \\
\text { spring pool, Shasta } \\
\text { Co., CA }\end{array}$ & \\
\hline $\begin{array}{l}\text { Fluminicola } \\
\text { turbiniformis }\end{array}$ & D34B & AY962986 & 1 & $0 \%$ & & $\begin{array}{c}\text { F. warnerensis, } \\
\text { differ by } \\
2.3-2.6 \%\end{array}$ & $\begin{array}{l}\text { Roaring Springs, } \\
\text { Harney Co., OR }\end{array}$ & \\
\hline \multirow[t]{5}{*}{$\begin{array}{l}\text { Fluminicola } \\
\text { umbilicatus }\end{array}$} & F8_92A & AY962987 & 1 & $0 \%$ & $\begin{array}{l}0.3 \% \text { with } \\
\text { F7_338A }\end{array}$ & $\begin{array}{c}\text { F. anserinus, } \\
\text { differ by } \\
3.5-3.8 \% \text {, } \\
\text { F. multifarius, } \\
\text { differ by } \\
3.5-4.3 \% \text {, } \\
\text { F. potemicus, } \\
\text { differ by } 3.8 \%\end{array}$ & $\begin{array}{l}\text { Lost Creek } \\
\text { (lowermost site), } \\
\text { Shasta Co., CA }\end{array}$ & \\
\hline & F8_93B & AY962988 & 1 & $0 \%$ & $\begin{array}{l}0.2 \% \text { with } \\
\text { F7_338A, } \\
\text { F8_536A, } \\
\text { F8_92A }\end{array}$ & $\begin{array}{c}\text { F. anserinus, } \\
\text { differ by } \\
3.3-3.6 \% \text {, } \\
\text { F. multifarius, } \\
\text { differ by } \\
3.3-4.1 \% \text {, } \\
\text { F. potemicus, } \\
\text { differ by } 3.6 \%\end{array}$ & $\begin{array}{l}\text { Lost Creek } \\
\text { (middle site), } \\
\text { Shasta Co., CA }\end{array}$ & \\
\hline & F7_99A & AY962989 & 1 & $0 \%$ & $\begin{array}{c}0.2 \% \text { with } \\
\text { F7_338A, } \\
\text { F8_536A, } \\
\text { F8_92A }\end{array}$ & $\begin{array}{c}\text { F. anserinus, } \\
\text { differ by } \\
3.3-3.6 \% \text {, } \\
\text { F. multifarius, } \\
\text { differ by } \\
3.3-4.1 \% \text {, } \\
\text { F. potemicus, } \\
\text { differ by } 3.6 \%\end{array}$ & $\begin{array}{l}\text { Big Spring, } \\
\text { tributary of Hat } \\
\text { Creek, Shasta Co., } \\
\text { CA }\end{array}$ & \\
\hline & F7_338A & AY962990 & 1 & $0 \%$ & $\begin{array}{l}\text { 0.3\% with } \\
\text { F8_536A, } \\
\text { F8_92A }\end{array}$ & $\begin{array}{l}\text { F. anserinus, } \\
\text { differ by } \\
3.5-3.8 \% \text {, } \\
\text { F. multifarius, } \\
\text { differ by } \\
3.5-4.3 \% \text {, } \\
\text { F. potemicus, } \\
\text { differ by } 3.8 \%\end{array}$ & $\begin{array}{l}\text { Hat Creek at Hat } \\
\text { Creek Resort, } \\
\text { Shasta Co., CA }\end{array}$ & \\
\hline & F8_536A & AY962991 & 1 & $0 \%$ & $\begin{array}{l}0.3 \% \text { with } \\
\text { F7_338A }\end{array}$ & $\begin{array}{c}\text { F. anserinus, } \\
\text { differ by } \\
3.5-3.8 \% \text {, } \\
\text { F. multifarius, } \\
\text { differ by } \\
3.5-4.3 \% \text {, } \\
\text { F. potemicus, } \\
\text { differ by } 3.8 \%\end{array}$ & $\begin{array}{l}\text { Lost Creek } \\
\text { (uppermost site), } \\
\text { Shasta Co., CA }\end{array}$ & \\
\hline $\begin{array}{l}\text { Fluminicola } \\
\text { virens }\end{array}$ & D41A & AY962992 & 1 & $0 \%$ & & $\begin{array}{l}\text { F. gustafsoni, } \\
\text { differ by } \\
6.2-6.6 \%\end{array}$ & $\begin{array}{l}\text { Willamette River } \\
\text { at Canby Ferry, } \\
\text { Clackamas Co., OR }\end{array}$ & \\
\hline $\begin{array}{l}\text { Fluminicola } \\
\text { virginius }\end{array}$ & D36B & AY962993 & 1 & $0 \%$ & & $\begin{array}{l}\text { F. dalli, differ } \\
\text { by } 5.8 \% \text {, } \\
\text { F. potemicus, } \\
\text { differ by } 5.5 \% \text {, } \\
\text { F. scopulinus, } \\
\text { differ by } \\
5.5-5.9 \%\end{array}$ & $\begin{array}{l}\text { Hardscrabble Creek, } \\
\text { Washoe Co., NV }\end{array}$ & \\
\hline
\end{tabular}




\begin{tabular}{|c|c|c|c|c|c|c|c|c|}
\hline Species & $\begin{array}{l}\text { Published } \\
\text { Sample } \\
\text { Codes }\end{array}$ & $\begin{array}{l}\text { Accession } \\
\text { Numbers }\end{array}$ & $\begin{array}{c}\text { No. of } \\
\text { Specimens }(\mathrm{N})\end{array}$ & $\begin{array}{l}\text { Sequence } \\
\text { Variation } \\
\text { (\% pairwise } \\
\text { distance) }\end{array}$ & $\begin{array}{l}\text { Most Distant } \\
\text { Conspecific } \\
\text { Sequences (\%) }\end{array}$ & $\begin{array}{c}\text { Closest } \\
\text { Interspecific } \\
\text { Sequences (\%) }\end{array}$ & Collection Locality & Comments \\
\hline \multirow[t]{7}{*}{$\begin{array}{l}\text { Fluminicola } \\
\text { warnerensis }\end{array}$} & F13_210B & AY962995 & 1 & $0 \%$ & $\begin{array}{l}0.6 \% \text { with } \\
\text { F13_351B }\end{array}$ & $\begin{array}{l}\text { F. turbiniformis, } \\
\text { differ by } 2.3 \%\end{array}$ & $\begin{array}{l}\text { Spring creek east of } \\
\text { Blue Lake, Modoc } \\
\text { Co., CA }\end{array}$ & \\
\hline & F13_217A & AY962996 & 1 & $0 \%$ & $\begin{array}{c}\text { 0.5\% with } \\
\text { SP360A, } \\
\text { FSP387F, } \\
\text { SP388A, } \\
\text { F10_482A, } \\
\text { F13_210B }\end{array}$ & $\begin{array}{l}\text { F. turbiniformis, } \\
\text { differ by } 2.4 \%\end{array}$ & $\begin{array}{l}\text { Parsnip Spring, } \\
\text { Lassen Co., CA }\end{array}$ & \\
\hline & F13_351B & AY962997 & 1 & $0 \%$ & $\begin{array}{c}0.6 \% \text { with } \\
\text { SP360A, } \\
\text { FSP387F, } \\
\text { SP388A, } \\
\text { F10_482A, } \\
\text { F13_210B }\end{array}$ & $\begin{array}{c}\text { F. turbiniformis, } \\
\text { differ by } 2.6 \%\end{array}$ & $\begin{array}{l}\text { Soup Spring, } \\
\text { Modoc Co., CA }\end{array}$ & \\
\hline & SP360A & AY962999 & 1 & $0 \%$ & $\begin{array}{l}0.6 \% \text { with } \\
\text { F13_351B }\end{array}$ & $\begin{array}{l}\text { F. turbiniformis, } \\
\text { differ by } 2.6 \%\end{array}$ & $\begin{array}{l}\text { Springs southeast } \\
\text { of Hilton, Modoc } \\
\text { Co., CA }\end{array}$ & \\
\hline & FSP387F & AY962998 & 1 & $0 \%$ & $\begin{array}{l}0.6 \% \text { with } \\
\text { F13_351B }\end{array}$ & $\begin{array}{l}\text { F. turbiniformis, } \\
\text { differ by } 2.6 \%\end{array}$ & $\begin{array}{l}\text { Springs east of } \\
\text { Miller Gulch, Modoc } \\
\text { Co., CA }\end{array}$ & \\
\hline & SP388A & AY 963000 & 1 & $0 \%$ & $\begin{array}{l}0.6 \% \text { with } \\
\text { F13_351B }\end{array}$ & $\begin{array}{l}\text { F. turbiniformis, } \\
\text { differ by } 2.6 \%\end{array}$ & $\begin{array}{l}\text { Miller Spring run, } \\
\text { Modoc Co., CA }\end{array}$ & \\
\hline & F10_482A & AY962994 & 1 & $0 \%$ & $\begin{array}{l}0.6 \% \text { with } \\
\text { F13_351B }\end{array}$ & $\begin{array}{l}\text { F. turbiniformis, } \\
\text { differ by } 2.6 \%\end{array}$ & $\begin{array}{l}\text { Rush Creek } \\
\text { (source), Modoc } \\
\text { Co., CA }\end{array}$ & \\
\hline \multirow[t]{2}{*}{$\begin{array}{l}\text { Fluminicola } \\
\text { sp. A }\end{array}$} & SP113A & AY962922 & 1 & $0 \%$ & $\begin{array}{l}0.2 \% \text { with } \\
\text { SP373B }\end{array}$ & $\begin{array}{l}\text { F. lunsfordensis, } \\
\text { differ by } 4.6 \%\end{array}$ & $\begin{array}{l}\text { Springs west of } \\
\text { Canby, Modoc Co., } \\
\text { CA }\end{array}$ & \\
\hline & $\begin{array}{l}\text { SP373B, } \\
\text { F2SP373A }\end{array}$ & $\begin{array}{l}\text { AY962924, } \\
\text { AY962925 }\end{array}$ & 2 & $0.2 \%$ & $\begin{array}{l}0.2 \% \text { with } \\
\text { SP113A }\end{array}$ & $\begin{array}{c}\text { F. Iunsfordensis, } \\
\text { differ by } \\
4.4-4.6 \%\end{array}$ & $\begin{array}{l}\text { Spring at west } \\
\text { end of Upper Rush } \\
\text { Creek Campground, } \\
\text { Modoc Co., CA }\end{array}$ & \\
\hline $\begin{array}{l}\text { Fluminicola } \\
\text { sp. B }\end{array}$ & $\begin{array}{l}\text { SP373A, } \\
\text { F2SP373E }\end{array}$ & $\begin{array}{l}\text { AY962923, } \\
\text { AY962926 }\end{array}$ & 2 & $0.2 \%$ & & $\begin{array}{c}\text { F. Iunsfordensis, } \\
\text { differ by } \\
2.4-2.5 \%\end{array}$ & $\begin{array}{l}\text { Spring at west end } \\
\text { of Upper Rush } \\
\text { Creek Campground, } \\
\text { Modoc Co., CA }\end{array}$ & \\
\hline \multicolumn{9}{|c|}{ Pristinicola } \\
\hline $\begin{array}{l}\text { Pnistinicola } \\
\text { hemphilli }\end{array}$ & & AF520940 & 1 & $0.00 \%$ & & & $\begin{array}{l}\text { Springs, } 1.8 \mathrm{~km} \\
\text { east of Lower } \\
\text { Kalama Hatchery, } \\
\text { Cowlitz Co., WA }\end{array}$ & \\
\hline \multicolumn{9}{|c|}{ Taylorconcha } \\
\hline \multirow[t]{4}{*}{$\begin{array}{l}\text { Taylorconcha } \\
\text { insperata }\end{array}$} & ows & $\begin{array}{l}\text { DQ75986- } \\
\text { DQ75990 }\end{array}$ & 5 & $0-0.46 \%$ & $\begin{array}{c}0-0.76 \% \\
\text { with OWD, } \\
0.15-0.76 \% \\
\text { with } \mathrm{HCH}\end{array}$ & $\begin{array}{c}\text { T. serpenticola, } \\
\text { differ by } \\
0.91-1.52 \%\end{array}$ & $\begin{array}{l}\text { Owyhee River, } \\
\text { upstream from } \\
\text { South Cross } \\
\text { Canyon, Malheur } \\
\text { Co., OR }\end{array}$ & \\
\hline & OWD & $\begin{array}{l}\text { DQ76011- } \\
\text { DQ76014 }\end{array}$ & 4 & $0-0.30 \%$ & $\begin{array}{c}0-0.76 \% \\
\text { with OWS }\end{array}$ & $\begin{array}{c}\text { T. serpenticola, } \\
\text { differ by } \\
1.06-1.82 \%\end{array}$ & $\begin{array}{l}\text { Owyhee River, } \\
\text { at Lower Deary } \\
\text { Pasture, Malheur } \\
\text { Co., OR }\end{array}$ & \\
\hline & $\mathrm{HCH}$ & $\begin{array}{l}\text { DQ75991- } \\
\text { DQ75995 }\end{array}$ & 5 & $0-0.15 \%$ & $\begin{array}{l}0.15-0.76 \% \\
\text { with OWS }\end{array}$ & $\begin{array}{c}\text { T. serpenticola, } \\
\text { differ by } \\
1.06-1.52 \%\end{array}$ & $\begin{array}{l}\text { Snake River, above } \\
\text { High Bar Rapids, } \\
\text { Wallowa Co., OR }\end{array}$ & \\
\hline & HCD & $\begin{array}{l}\text { DQ76023- } \\
\text { DQ76027 }\end{array}$ & 5 & $0 \%$ & $\begin{array}{c}0-0.61 \% \\
\text { with OWS }\end{array}$ & $\begin{array}{c}\text { T. serpenticola, } \\
\text { differ by } \\
1.22-1.52 \%\end{array}$ & $\begin{array}{l}\text { Snake River, just } \\
\text { below Davis Creek } \\
\text { Rapids, Wallowa } \\
\text { Co., OR }\end{array}$ & \\
\hline
\end{tabular}




\begin{tabular}{|c|c|c|c|c|c|c|c|c|}
\hline Species & $\begin{array}{l}\text { Published } \\
\text { Sample } \\
\text { Codes }\end{array}$ & $\begin{array}{l}\text { Accession } \\
\text { Numbers }\end{array}$ & $\begin{array}{c}\text { No. of } \\
\text { Specimens }(\mathrm{N})\end{array}$ & $\begin{array}{c}\text { Sequence } \\
\text { Variation } \\
\text { (\% pairwise } \\
\text { distance) }\end{array}$ & $\begin{array}{l}\text { Most Distant } \\
\text { Conspecific } \\
\text { Sequences (\%) }\end{array}$ & $\begin{array}{c}\text { Closest } \\
\text { Interspecific } \\
\text { Sequences (\%) }\end{array}$ & Collection Locality & Comments \\
\hline \multirow[t]{12}{*}{$\begin{array}{l}\text { Taylorconcha } \\
\text { serpenticola }\end{array}$} & $\mathrm{NI}$ & $\begin{array}{l}\text { DQ75952- } \\
\text { DQ75956 }\end{array}$ & 5 & $0-0.30 \%$ & $\begin{array}{l}0.15-0.76 \% \\
\text { with TSM }\end{array}$ & $\begin{array}{l}\text { T. insperata, } \\
\text { differ by } \\
1.06-1.82 \%\end{array}$ & $\begin{array}{l}\text { Niagara Springs, } \\
\text { outflow at base } \\
\text { of falls, Gooding } \\
\text { Co., ID }\end{array}$ & \\
\hline & BA & $\begin{array}{l}\text { DQ76019- } \\
\text { DQ76022 }\end{array}$ & 4 & $0 \%$ & $\begin{array}{l}0.15-0.46 \% \\
\text { with TSN, NI }\end{array}$ & $\begin{array}{l}\text { T. insperata, } \\
\text { differ by } \\
1.22-1.67 \%\end{array}$ & $\begin{array}{l}\text { Banbury Springs } \\
\text { outlets, Gooding } \\
\text { Co., ID }\end{array}$ & \\
\hline & SA & $\begin{array}{l}\text { DQ75961- } \\
\text { DQ75965 }\end{array}$ & 5 & $0 \%$ & $\begin{array}{l}0.15-0.46 \% \\
\text { with TSM }\end{array}$ & $\begin{array}{l}\text { T. insperata, } \\
\text { differ by } \\
1.06-1.52 \%\end{array}$ & $\begin{array}{l}\text { Sand Spring, ca. } \\
30 \mathrm{~m} \text { below source, } \\
\text { Gooding Co., ID }\end{array}$ & \\
\hline & TSN & $\begin{array}{l}\text { DQ75996- } \\
\text { DQ776000 }\end{array}$ & 5 & $0-0.61 \%$ & $\begin{array}{c}0.15-0.76 \% \\
\text { with TSM }\end{array}$ & $\begin{array}{l}\text { T. insperata, } \\
\text { differ by } \\
0.91-1.52 \%\end{array}$ & $\begin{array}{l}\text { Spring pool of } \\
\text { Thousand Springs } \\
\text { north outlet, } \\
\text { Gooding Co., ID }\end{array}$ & \\
\hline & TSM & $\begin{array}{l}\text { DQ76015- } \\
\text { DQ76018 }\end{array}$ & 4 & $0-0.61 \%$ & $\begin{array}{c}0.15-0.76 \% \\
\text { with NI, TSN }\end{array}$ & $\begin{array}{l}\text { T. insperata, } \\
\text { differ by } \\
1.06-1.67 \%\end{array}$ & $\begin{array}{l}\text { Thousand Springs, } \\
\text { springs just south } \\
\text { of The Nature } \\
\text { Conservancy's } \\
\text { water pipeline, } \\
\text { south of north inlet, } \\
\text { Gooding Co., ID }\end{array}$ & \\
\hline & TSS & $\begin{array}{l}\text { DQ76001- } \\
\text { DQ76005 }\end{array}$ & 5 & $0 \%$ & $\begin{array}{l}0.15-0.46 \% \\
\text { with TSM }\end{array}$ & $\begin{array}{l}\text { T. insperata, } \\
\text { differ by } \\
1.06-1.52 \%\end{array}$ & $\begin{array}{l}\text { Thousand Springs, } \\
\text { southernmost and } \\
\text { largest outflow of } \\
\text { the Minnie Miller } \\
\text { Springs complex, } \\
\text { Gooding Co., ID }\end{array}$ & \\
\hline & $\mathrm{BI}$ & $\begin{array}{l}\text { DQ75957- } \\
\text { DQ75960 }\end{array}$ & 4 & $0 \%$ & $\begin{array}{l}0.15-0.46 \% \\
\text { with TSM }\end{array}$ & $\begin{array}{l}\text { T. insperata, } \\
\text { differ by } \\
1.06-1.52 \%\end{array}$ & $\begin{array}{l}\text { Billingsley Creek, } \\
\text { at spring source, } \\
\text { Gooding Co., ID }\end{array}$ & \\
\hline & $\mathrm{CO}$ & $\begin{array}{l}\text { DQ75966- } \\
\text { DQ75970 }\end{array}$ & 5 & $0-0.30 \%$ & $\begin{array}{l}0.15-0.61 \% \\
\text { with TSM }\end{array}$ & $\begin{array}{l}\text { T. insperata, } \\
\text { differ by } \\
0.91-1.67 \%\end{array}$ & $\begin{array}{l}\text { Cove Creek, just } \\
\text { above diversion } \\
\text { to Malad River, } \\
\text { Gooding Co., ID }\end{array}$ & \\
\hline & MA & $\begin{array}{l}\text { DQ76006- } \\
\text { DQ76010 }\end{array}$ & 5 & $0 \%$ & $\begin{array}{l}0.15-0.46 \% \\
\text { with TSM }\end{array}$ & $\begin{array}{l}\text { T. insperata, } \\
\text { differ by } \\
1.06-1.52 \%\end{array}$ & $\begin{array}{l}\text { Snake River, just } \\
\text { below Malad } \\
\text { Power Plant outfall, } \\
\text { Gooding Co., ID }\end{array}$ & \\
\hline & $\mathrm{ZI}$ & $\begin{array}{l}\text { DQ75971- } \\
\text { DQ75975 }\end{array}$ & 5 & $0-0.15 \%$ & $\begin{array}{c}0.15-0.61 \% \\
\text { with TSM }\end{array}$ & $\begin{array}{l}\text { T. insperata, } \\
\text { differ by } \\
0.91-1.52 \%\end{array}$ & $\begin{array}{l}\text { Snake River, above } \\
\text { Bliss Reservoir, } \\
\text { Gooding Co., ID }\end{array}$ & \\
\hline & $\mathrm{BC}$ & $\begin{array}{l}\text { DQ75981- } \\
\text { DQ75985 }\end{array}$ & 5 & $0-0.15 \%$ & $\begin{array}{l}0.15-0.61 \% \\
\text { with TSM }\end{array}$ & $\begin{array}{l}\text { T. insperata, } \\
\text { differ by } \\
0.91-1.67 \%\end{array}$ & $\begin{array}{l}\text { Snake River, just } \\
\text { below Bancroft } \\
\text { Springs, Elmore } \\
\text { Co., ID }\end{array}$ & \\
\hline & $\mathrm{CL}$ & $\begin{array}{l}\text { DQ75976- } \\
\text { DQ75980 }\end{array}$ & 5 & $0-0.15 \%$ & $\begin{array}{l}0.15-0.61 \% \\
\text { with TSM }\end{array}$ & $\begin{array}{l}\text { T. insperata, } \\
\text { differ by } \\
0.91-1.52 \%\end{array}$ & $\begin{array}{l}\text { Snake River, just } \\
\text { above Clover Creek } \\
\text { confluence, Elmore } \\
\text { Co., ID }\end{array}$ & \\
\hline
\end{tabular}

\section{BLM Library \\ Denver Federal Center \\ Bldg. 50, OC-521 \\ P.O. Box 25047 \\ Denver, CO 80225}




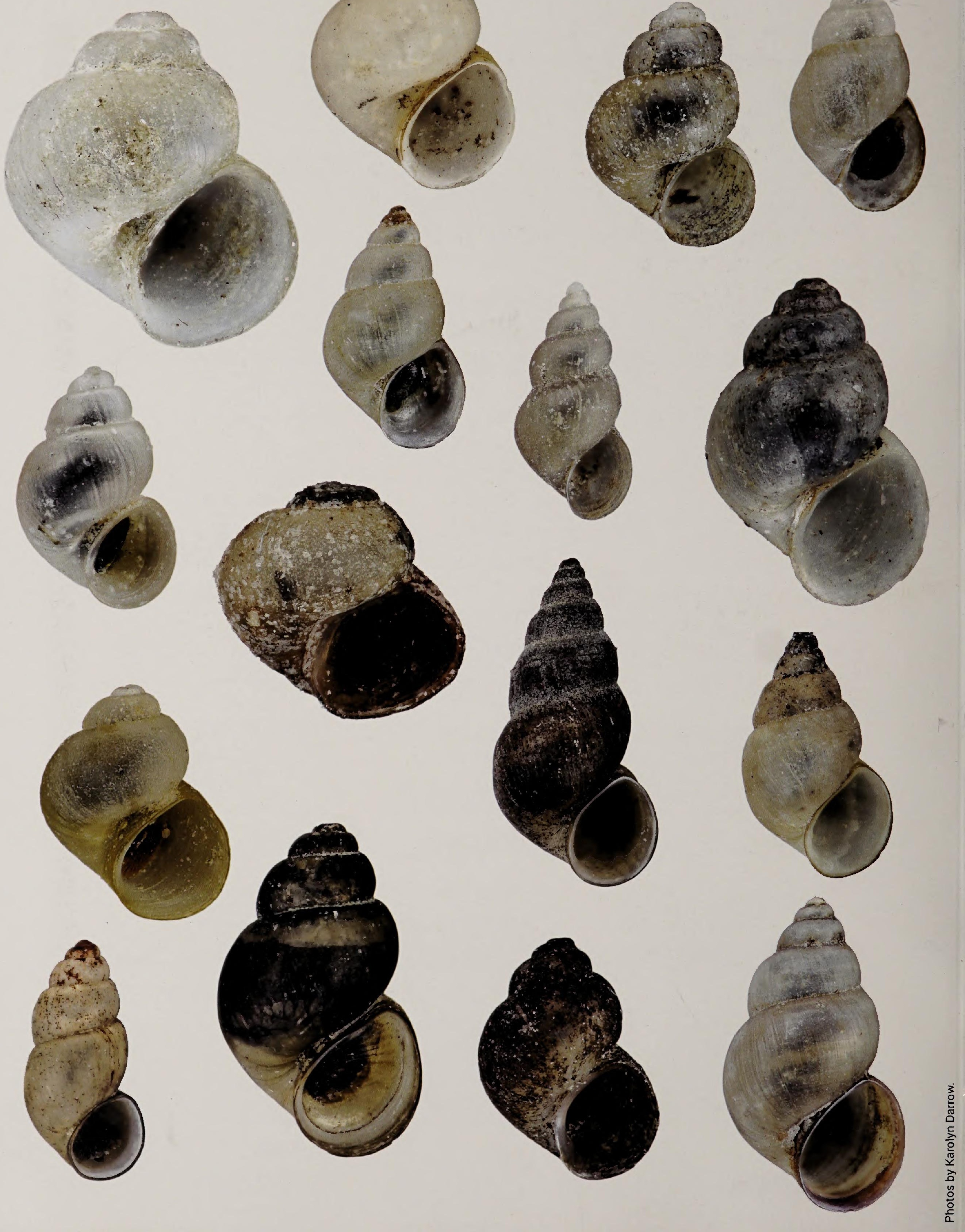

